

\section{STUDIA UNIVERSITATIS HEREDITATI}

Znanstvena revija za raziskave in teorijo kulturne dediščine

Letnik 7, številka I, 2019

Glawni in odgovorni urednik

dr. Gregor Pobežin (Fakulteta za humanistične študije Univerze na Primorskem, Koper)

Urednicastevilke

dr. Zrinka Mileusnić (Fakulteta za humanistične študije Univerze na Primorskem, Koper)

Tehnična ureditev revije, oblikovanje in prelom

dr. Jonatan Vinkler (Fakulteta za humanistične študije Univerze na Primorskem, Koper)

Uredniski odbor

dr. Vesna Bikić (Arheološki institut Beograd, SANU), dr. Jadranka Cergol (Fakulteta za humanistične študije Univerze na Primorskem, Koper), dr. Zdravka Hincak (Filozofski fakultet, Sveučilište u Zagrebu), dr. Matej Hriberšek (Filozofska fakulteta, Univerza v Ljubljani), dr. Katja Hrobat Virloget (Fakulteta za humanistične študije Univerze na Primorskem, Koper), dr. Irena Lazar (Fakulteta za humanistične študije Univerze na Primorskem, Koper), dr. Zrinka Mileusnić (Fakulteta za humanistične študije Univerze na Primorskem, Koper), dr. Tea Perinčić (Pomorski i povijesni muzej Hrvatskog primorja Rijeka), dr. Maša Sakara Sučevič (Pokrajinski muzej, Koper), dr. Alenka Tomaž (Fakulteta za humanistične študije Univerze na Primorskem, Koper), dr. Tomislav Vignjevič (Fakulteta za humanistične študije Univerze na Primorskem, Koper), dr. Jonatan Vinkler (Fakulteta za humanistične študije Univerze na Primorskem, Koper), dr. Paola Visentini (Museo Friulano di Storia Naturale, Udine)

Izdajatelj: Univerza na Primorskem - Založba Univerze na Primorskem (za Fakulteto za humanistične študije Univerze na Primorskem)

(C) 2019 Založba Univerze na Primorskem

Zanjo: prof. dr. Klavdija Kutnar, rektorica

Titov $\operatorname{trg} 4$

SI-6000 Koper

ISSN $2350-5443$

DOI: https://doi.org/10.26493/2350-5443.7(I)

\section{(c) (1) $(9)$


studia universitatis hereditati 



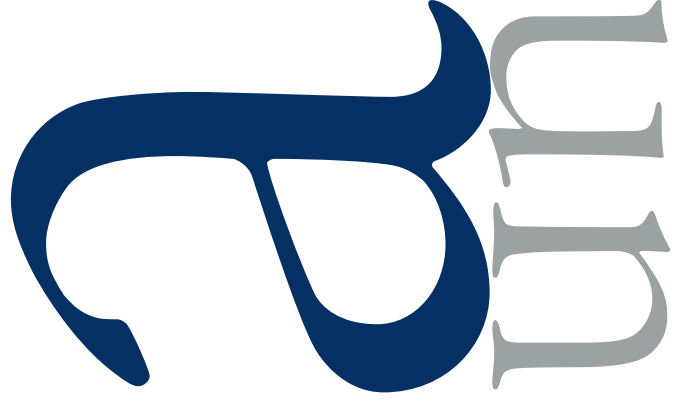

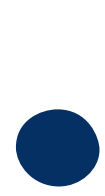
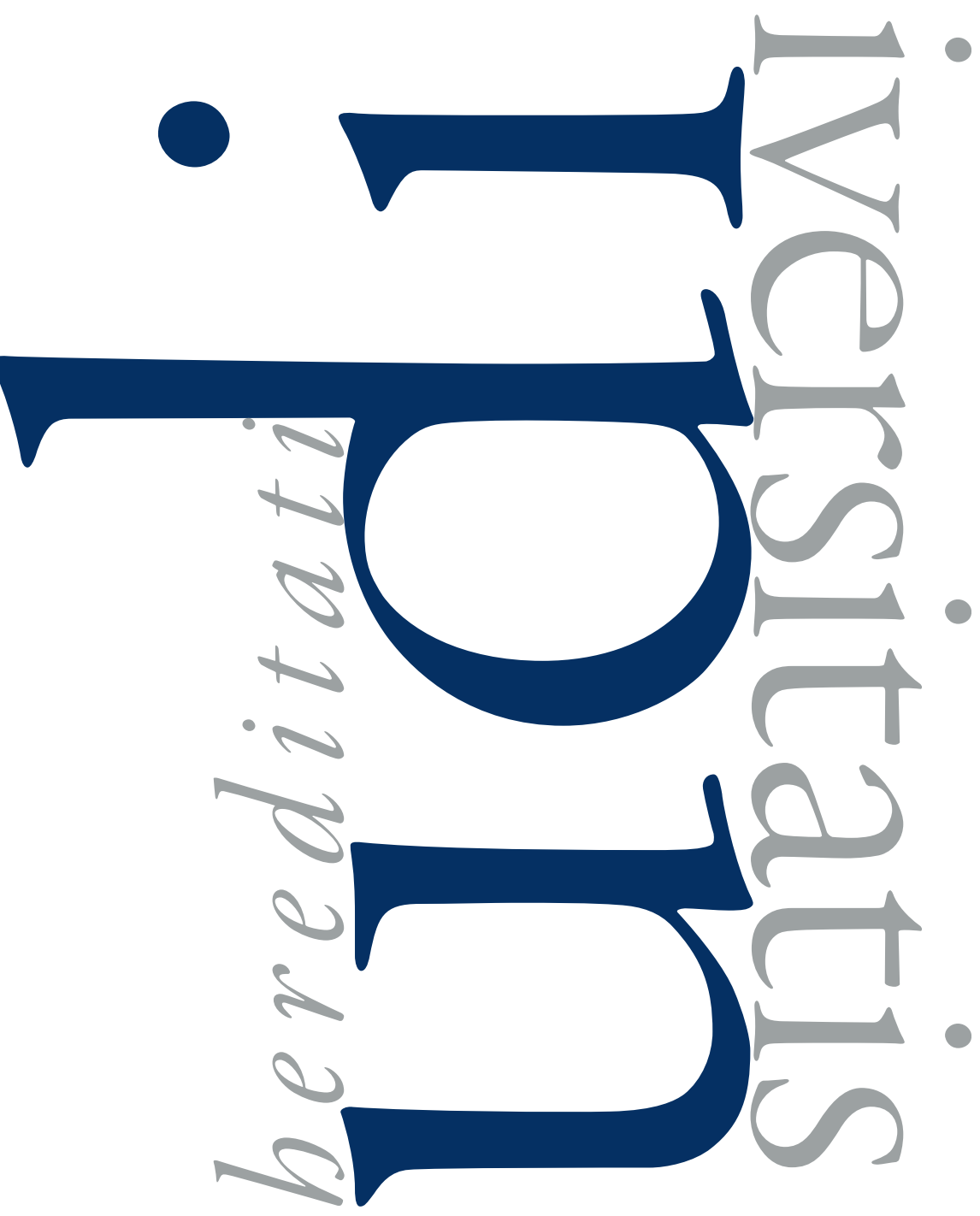

LETNIK 7

ŠTEVILKA I

LETO 2019
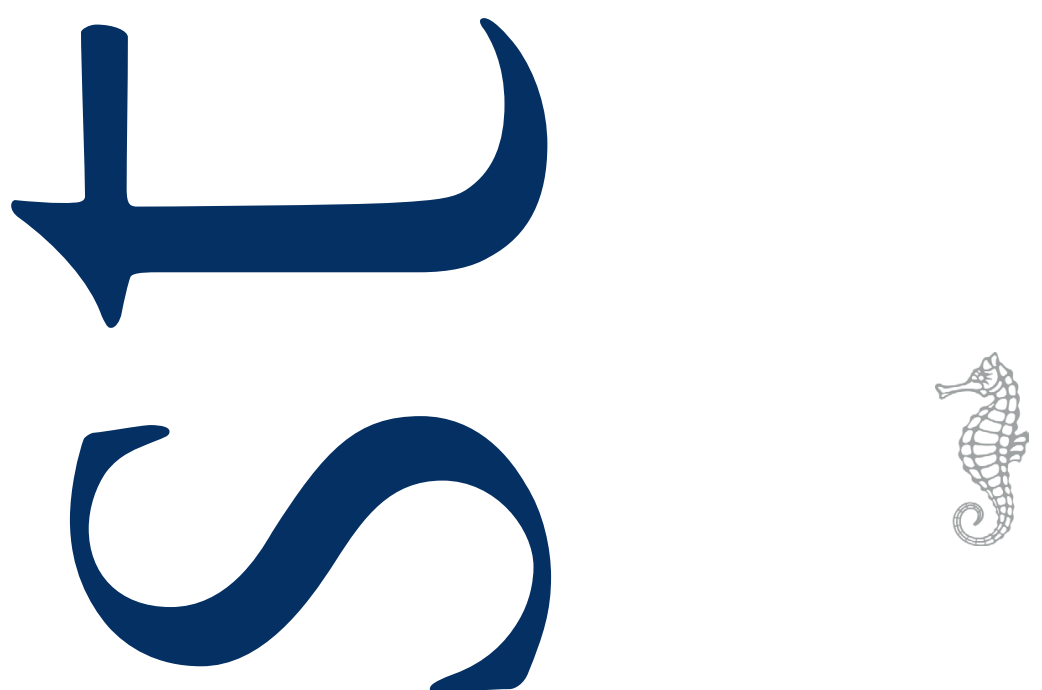
-

r

$\downarrow$

G

1

-

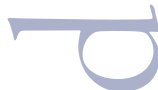

( )

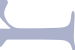

(U)

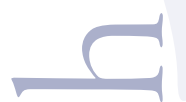




\section{Vsebina/Contents}

JernejRibter

9 Poplavna ravnica reke Save na Krškem polju kot gospodarsko zaledje kmečkih gospodarstev v prvi polovici 20 . stoletja

Francilazarini

63 »Prekrasni arhitektov sen o našem Pantheonu«

- Plečnikovi neuresničeni načrt za slavnostno pokopališče zaslužnih Slovencev

Janja Babelić

79 Odtujevanje kulturne dediščine:

primer premeščenih artefaktov iz mest Slovenske Istre

Dobrila Vlabović

97 Kulturna baština Prijestonice Cetinja: simboli kolektivnog sjećanja na Drugi svjetski rat (Bunkeri iz doba okupacije u Drugom svjetskom ratu)

Gorazd Sedmak, Aleksandra Brezovec, Neža Čebron Lipovec in Ana Plestenjak

II3 Povezovanje turizma in kreativnih industrij pri oživljanju opuščene industrijske dediščine skladišča Monfort 
-

r

$\downarrow$

G

1

-

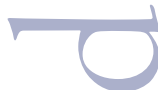

( )

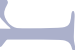

(U)

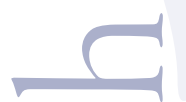




\section{Poplavna ravnica reke Save na Krškem polju kot gospodarsko zaledje kmečkih gospodarstev v prvi polovici 20 . stoletja}

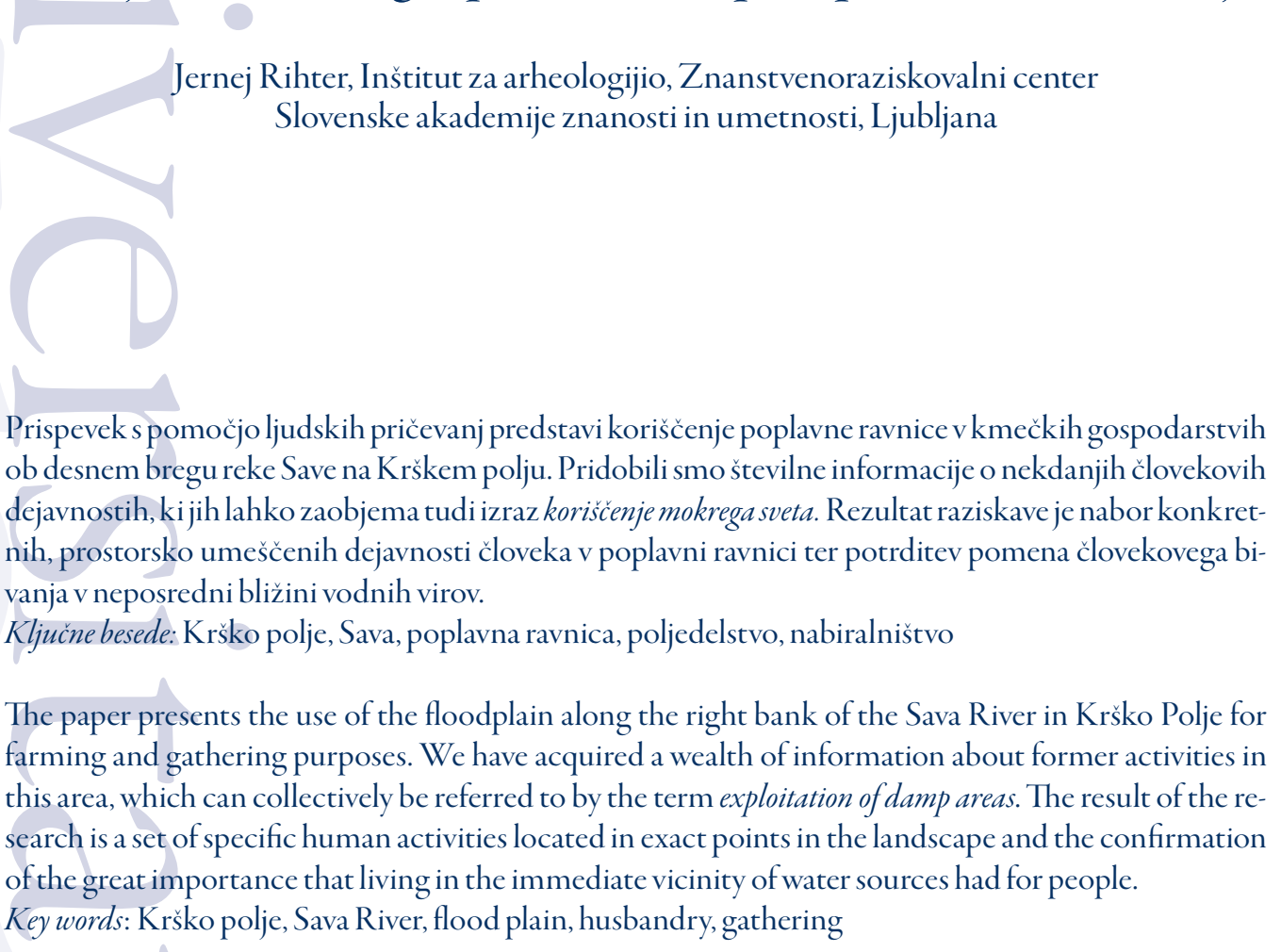

$\mathrm{P}$ regled človekovih dejavnosti $\mathrm{v}$ poplavni ravnici temelji na ljudskih pričevanjih, ki se nanašajo na prostor med reko Savo in vasmi med Drnovim in D. Skopicami na Krškem polju. Gre za razširjeno nadaljevanje podobno zasnovanega dela, ki obravnava različne vidike človekove povezanosti s poplavno ravnico na območju G. in D. Skopic (Rihter 20Io). Ta je temeljil na popisu izbranih kulturnih in naravnih posebnosti na tem istem območju (Rihter 2007), idejno pa na pripovedih Uršule Vodopivec in na njeni kasnejši knjigi spominov (2008). ${ }^{2}$ Večina pričevanj in izročil, zabeleženih na raz-

I Podatke zbiram avtor tega prispevka, ki hranim celoten arhiv pričevanj in izročil. Informatorji so označeni s naključno tričrkovno oznako.

2 Uršula Vodopivec: Knjiga spominov »Za Jerneja« 2008 (rokopis); obseg 145 str., format As (neobjavljeno) (gl. Literatura). Posamezni izseki iz strani p. 33, p. 37, p. 64-72 in p. 90 , so bili objavljeni pri Rihter (2010). lične medije, je bilo nesistematično zbranih med leti 2004-2016. ${ }^{3}$ Sredi leta 2016, ko je bila zaključena neobjavljena različica pričujočega prispevka, je celotno območje raziskave zajela izgradnja zajezitvenega bazena za HE Brežice. Pri tem je prišlo do popolne spremembe obrečnega okolja celotnega območja, ki nas $\mathrm{v}$ tej raziskavi najbolj zanima. Zato naj bralec različna sklicevanja in lociranja $\mathrm{v}$ prostoru na topografski podlagi (Sl. I), v naravi razume v kontekstu stare savske struge pred letom 2016/2017, torej pred zajezitvijo. Zbirka podatkov in s tem tudi pričujoče delo, je bilo kasneje dopolnjeno z novimi pričevanji, zbranimi vključno do julija 2019.

Zbranih je bilo več stotin živih toponimov. Med njimi so številni še danes v uporabi, mno-

\footnotetext{
Raziskovanje življenja s poplavno ravnico izvajam avtor zapisa.

$\mathrm{Za} \gg z ̌ i v e \ll$ toponime štejem tiste, ki so bili zbrani preko ustnih virov in jih je bilo moč z informatorji tudi locirati. Približno petina vseh
} 
go pa je takih, ki so iz uporabe prešli s komasacijo kmetijskih zemljišč. Do leta 2014 je bilo celotno območje, $\mathrm{z}$ dragoceno izjemo $\mathrm{I}, 5 \mathrm{~km}^{2}$ polja pod vasjo Drnovo (gl. Paša ...), že v celoti komasirano (Rihter 2015, II-I5). Navkljub temu je bilo možno vse toponime, tudi takšne, ki so po komasaciji izšli iz redne uporabe, $\mathrm{z}$ informatorji zbrati, preveriti ter $s$ pomočjo starejših ortografskih posnetkov prostorsko umestiti in prenesti na topografsko podlago. $\mathrm{V}$ naši raziskavi nastopajo le tisti toponimi, na katere je vezana informacija o človekovih dejavnostih. Vsak toponim, ki ga omenjamo, je umeščen na topografski karti v merilu I: 25000 (Sl. I) in sicer pod tekočo številko od I-II 4. Vrstni red številk toponimov sledi prvi omembi toponima $\mathrm{v}$ tekstu.

Velika količina toponimov za prostor, ki skozi današnjo gospodarsko perspektivo nima več posebnega pomena, priča o tem, da je bilo $\mathrm{v}$ preteklosti drugače. Razvidno je, da so bila v prvi polovici 20. stoletja še vsa zemljišča poplavne ravnice poimenovana, kar implicira njeno pomembnost za človeka oziroma njegovo vsakdanjo prisotnost $\mathrm{v}$ njej.

Nekatera pričevanja so unikatna, druga je bilo moč preveriti pri več informatorjih. Za mnoge dejavnosti najdemo primerjave $\mathrm{v}$ drugih primerljivih okoljih, vendar njihovo navajanje ni predmet tega prispevka. Podajamo jih le v primerih, ko želimo osvetliti kakšno izmed manj jasnih trenskih informacij ali pa kadar želimo bralca napotiti na lokalno zadevne primerjave. Drobci raznovrstnih pričevanj o človekovih dejavnostih $\mathrm{v}$ tem delu poplavne ravnice, so bili objavljeni na več mestih (Rihter 2006; isti 2008; isti 20I0; isti 20II; isti 2014; isti 2015).

V zvezi s tem izpostavimo delo Življenjepisi Štajercev in Kranjcev ob sotočju rek Krke, Save in Sotle (Iz časov jećmenove kave) avtorice Ivanke Počkar (1998), ki s podatki v obliki ljudskih pričevanj sega tudi v neposredno soseščino našega interesnega območja. Med njimi so nekatere locirane tudi v poplavni obrečni svet spodnjega Posavja (Počkar 1998, 46-313, passim).

toponimov je del avtorjevega lastnega/vaškega/topografskega repertoarja, kot domačina.
Zbrana je bila velika količina prvoosebnih pričevanj o nekdanji izrabi poplavne ravnice, kot pomembnem gospodarskem zaledju tukajšnjih kmetij. Predvsem izstopajo podatki o koriščenju mokrega sveta. Pri tem se je porodilo vprašanje, kako je mogoče, da so bili informatorji, rojeni v prvih štirih desetletjih 20. stoletja, še priča povsem drugačni podobi poplavne ravnice, kot bi jo pričakovali, navkljub sto let poprej pričeti savski regulaciji? Del odgovorov je ponudil pregled zgodovine regulacijskih del in drugih podatkov, ki se nanašajo na prostor reke Save med Krškim in Brežicami v 19. in 20 stoletju (npr. Kronberg I839; Costa I848; Lapajne I894; Vrhovec I895; Teppey 1977; Umek 1986 in 1996; Verbič in Berič 1993; Ripšl 2007; Šebek 2009, Počkar 2009; Mlekuž 2009; Rihter 2015 in 2016a-d), del pa usmerjeno spraševanje informatorjev o izgle$\mathrm{du}$ in izrabi različnih predelov poplavne ravnice $\mathrm{v}$ času pred letom $194 \mathrm{I}^{5}$ (Rihter 2007; isti 20ıo; isti 20I5; glej dalje). Izkazalo se je, da je šlo za čas, ko so leta I 829 pričeta regulacijska dela na reki Savi med Krškim in Brežicami trajala že več kot sto let, utrditvena dela pa so bila še vedno v teku (Rihter 2015, 6I-62; Teppey 1977, 29). Dokončna izravnava struge oz. njena ustaljenost $\mathrm{v}$ poteku, ki je podoben današnjemu, ${ }^{6}$ pa je bila izvedena šele do leta 1945 (Šebek 2009; Rihter 2015; 2016a, 59) oz. do druge polovice 20. stoletja (Verbič 2008, 38; prim. Teppey 1977, 29). Regulacija je porušila nekdanji naravni ekosistem, ki se je od današnjega, antropogenega precej razlikoval (Verbič in Berič 1993,333 ).

Zaradi neposrednih vezi informatorjev, rojenih $\mathrm{v}$ prvi polovici 20 . stoletja, $\mathrm{z}$ generacijami (starih) staršev rojenimi v 2. pol. 19. stoletja in njihove navezanosti na iste prostore $\mathrm{v}$ poplavni ravnici, lahko danes, na pragu tretjega tisočletja, ko (ravnica) ni več ohranjena $v$ tedanji obliki, razpolagamo z zelo konkretnimi pričevanji o postopnih spremembah obrečnega okolja in hkrati o spremenjenih dejavnostih človeka v njem.

5 Letnicaje okvirni mejnik, ki ga predstavlja internacija krškopoljskega prebivalstva v nemška taborišča. Ta je pri večini pripovedovalcev potekala v zadnji tretjini leta I94I in v prvih dveh mesecih leta 1942. Mišljeno za podobo struge, ki je tu obstajala do leta 2015/2016 pred pričetki del za HE Brežice. 
Današnje korito Save je umetno in seka meandre iz različnih zgodovinskih obdobij. Navkljub temu je reka pogosto poplavljala na jugovzhodnem območju Vrbine (Verbič 2004, I85, S1. 2). Hidrotehnični ukrepi so le počasi vplivali na številčnost poplav in na mrtvice ter seveda na gladino talne vode. Odziv na spremenjeno stanje rečnega toka se je mdr. razmeroma hitro kazal na rastju, tudi v rečnem zaledju in posledično $\mathrm{v}$ načinu človekove izrabe mokrega sveta. Z leti je Sava lastno korito poglabljala, s tem pa tudi nivo talne vode v vodonosniku. Seveda je vse postopne spremembe najprej zaznal in spremljal tukajšnji človek, saj je bil s poplavno ravnico tedaj življenjsko še povezan. Po letu I94I je ta sodvisnost plahnela, vendar je bila tedaj še prvi dve povojni desetletji izrednega pomena.

Iz pričevanj je možno povzeti in nanizati poglavitne mejnike v razvoju obsavske pokrajine v njenem poregulacijskem obdobju. Tako je bil v vseh vaseh še zabeležen spomin na rečno plovbo, ne le splavarjev, ki so delovali še dolgo v 2o. stoletje, temveč tudi na mnogo starejšo ladijsko plovbo, ki naj bi se po zgodovinskih virih okvirno zaključila leta I862 (Lapajne I894, Vrhovec I895) in $\mathrm{z}$ njo povezanimi pričevanji o poteku vlečnih poti, potrebami po živini, pletenju vlečnih vrvi, ipd. Sledijo pričevanja o regulaciji in izgradnjah regulacijskih arhitektur, med katerimi npr. Petrova škarpa na Vihrah dokumentirano sega še pred sredo 19. stoletja (Rihter 2016a-c). Predvsem $\mathrm{v}$ vzhodni polovici obravnavanega prostora v prvih desetletjih 20. stoletja opisujejo izjemno plitvost novoizkopanega savskega korita predvsem med Skopiškim zalivom in nekdanjo vasjo Zasavje (Rihter 2015, 272). To se sklada s pričevanji o pogostem prestopanju bregov reke na tem odseku in posledično o angažiranju delavcev $v \mathrm{t}$. i. savski službi, ki je skrbela za utrjevanje razritih bregov in za izdelovanje raznovstnih vrbovih fašin (Rihter 2010, 2016a, b, c).

Človekovo koriščenje mokrega sveta se je zmanjševalo z stabilizacijo savskega korita in postopoma jenjalo, sledeč spremenjenim razmeram pa se je tudi prostorsko premikalo. To se kaže v pričevanjih o starih in novih lokacijah opravlja- nja kakšne izmed dejavnosti. Takšna so npr. pričevanja o starih periščih na Mrtvicah ali o starih pašnih območjih za prašiče na brižanskem (gl. Mokri svet vrbine). O podobni (čeprav natančneje nedatirani) dinamiki govori tudi del toponimov, kot so Stari vrti, Brodišče, Stare gmajne, Turški brod, idr. Zadnjo večjo spremembo so v vaseh zaznali po izgradnji jezovne zgradbe za NE Krško, ko so presahnile še zadnje delujoče štirne, saj se je od jezu dolvodno, savsko korito dodatno poglobilo in s tem tudi vodostaj talne vode. Njen nivo se je v zaledju ponovno zvišal po izgradnji nove jezovne zgradbe za HE Brežice v letu 20I8, ko so prebivalci zaznali pojave talne vode $\mathrm{v}$ gramoznicah in strugah, tudi tam, kjer poprej do tega ni prihajalo.

V kolikor strnemo, je v začetni fazi neuspešna savska regulacija (Rihter 20I5, 6I-69) podaljšala obdobje nekaterih možnosti izkoriščanja $\mathrm{z}$ vodno prisotnostjo povezanih zemljišč, še za eno stoletje, in sicer najmanj do pričetka 2. svetovne vojne, ponekod, v omejenem obsegu pa še dlje. Tako je poplavna ravnica v prvi polovici 20. stoletja marsikje, zlasti pa na območju Gorenjih in Dolenjih Skopic še vedno kazala podobo, ki je ohranjala številne naravne elemente značilnejše za čas pred regulacijo, čeprav so ti ravno tedaj že pospešeno izginjali (Rihter 20IO). Biodiverziteta takšnega okolja je bil izjemna, vendar je v poregulacijskem obdobju prišlo do njenega osiromašenja, ki ga je pospešila človekova povojna vrnitev $\mathrm{v}$ poplavno ravnico, ki je bila agresivnejša kot poprej, predvsem pa mehanizirana ter motivirana $v$ duhu intenzivne gospodarske izrabe.

To spoznanje je pomenilo potrditev, da je na terenu še možno pridobiti kvalitetna, prvoosebna in prostorsko umeščena pričevanja o podobi poplavne ravnice pred letom I94I in o načinih njenega neintenzivnega koriščenja. Pričujoče delo sledi predpostavki, da v kolikor naravne danosti pri naselbinah in njenih radijih niso nepomembne, po tem nas za določeno obdobje nujno zanima, kakšne so bile te naravne danosti in predvsem, katere od teh je človek dejansko izkoriščal. Nabor vedenj, ki izhaja iz obeh možnosti 
pa nam prejkone odpira globlji vpogled v zgodovino prostora in človeka.

\section{Kulturne in naravne danosti}

$S$ širšega prostora obravnavanih vasi so znane prazgodovinske, rimske in zgodnjesrednjeveške arheološke najdbe (Petru in Petrui978; Bavec 2006; 2009, 57-63). Te kažejo na intenzivno, še zlasti rimskodobno poselitev. Tod namreč vodi trasa rimske itinerarske ceste, ob kateri je na območju današnjega Drnovega stalo antično mesto Neviodunum (Petru 1978). Prve pisne omembe imen današnjih vasi sodijo $\mathrm{v}$ čas od srede I4. do srede I5. stoletja (Mlinarič 1977, 26-28, 44), ko se, najbrž že na robovih poplavne ravnice, prvič omenjajo predhodnjice kmetij v današnjih vaseh. Dandanes jih druži lega natnačno ob robu poplavne ravnice, katere značilnost je prepredenost z opuščenimi, pretežno meandrirajočimi rečnimi tokovi. Zato so njeni robovi oblikovani kot meanderski loki (Verbič 2004, I84-I85). To je hkrati tudi najbolj očitna morfološka razlika, ko poplavno ravnico primerjamo z zgornjepleistocensko teraso, ki je zaradi človekove dalj časa trajajoče obdelave navidez že povsem ravna (Verbič 2004, 184-185).

Sledi opis nekaterih geoloških značilnosti območja, zato ponovno spomnimo, da z izrazom poplavna ravnica $v$ pričujoči obravnavi označujemo v najširšem smislu območje tukajšnjih holocenskih savskih teras, imenovanih Vrbina/e. Ta zemljišča so bila $\mathrm{v}$ naravnem stanju večkrat poplavljena, zaradi človekovih posegov $\mathrm{v}$ rečno strugo pa dandanes ob povodnji vse terase niso poplavljene. Za polje nad poplavno ravnico, ki ga povodenj v holocenu praviloma ni dosegala, $\mathrm{v}$ geologiji zaobjema poimenovanje zgornjepleistocenska terasa. V nadaljevanju krajše, tudi pleistocenska terasa.

Razen G. in D. Skopic, vse vasi stojijo na pleistocenski terasi, oziroma natančneje, na skrajnem robu zgornjepleistocenskega prodnega zasipa (gl. Verbič 2004, I84-I84). Krško polje je namreč prekrito $s$ prodnimi savskimi zasipi različnih starosti (Verbič 1993, 327). V zadnji (zgornjepleistocenski) prodni zasip ledene dobe, pa je reka Sava urezala še holocenske terase, ki so po nastanku erozijske površine (Verbič 1993, 327330; 2004, 185, gl. Stritar 1977, 627-638).

Tako je med holocenskimi in zgornjo pleistocensko teraso nastala značilna več metrov visoka višinska razlika, ki je najočitnejša za vasi na razdalji med Drnovim in Vihrami. $S$ tem vasi višinsko dominirajo nad poplavno ravnico. Obrežna narava vasi in sama dvojnost zgoraj/spodaj $v$ odnosu do poplavne ravnice, se dodatno izraža $\mathrm{v}$ pedoloških in posledično $\mathrm{v}$ agrarnih danostih teh vasi.

Z vidika kmetijstva se v podsekvenci na produ in pesku pojavljata dve združbi tal in sicer na holocenskih terasah združba obrečnih tal in na pleistocenski terasi združba rjavih tal. Naravna meja med njima zato poteka po ježi, ki deli holocensko območje od pleistocenskega. To pa je istočasno meja, ki deli združbo obrečnih tal od združbe rjavih tal (Stritar 1990, 52-53; 1977, 636-637). Ljudska prostorska delitev vaško polje npr. na Drnovem, loči na delenske in gorenske njive, kjer za slednje velja tudi krajše poimenovanje pule ali na pul. Pule je tu sinonim za njive na pleistocenski terasi. V obravnavi bomo za slednje uporabili izraz zgornje polje, za njive na holocenskih terasah, ki so bile izkrčene v poplavni ravnici, pa spodnje polje (Sl. 2).

Ta delitev ima v lokalni rabi (in v zavesti) že vgrajeno pomensko informacijo o rodovitnosti ali bolje rečeno o stanovitnosti spodnjega polja, ki se bolj obnese tudi v primeru suše. Čeprav sta obe polji v osnovi rodovitni, je splošno znano, da huda suša na zgornjem polju lahko uniči skoraj celoten pridelek. Nasprotno pa je možno v spodnjem polju sočasno celo spraviti nekaj pridelka. Prav tako pa je bilo lahko spodnje polje ponekod premokro za posevke ali pa nepričakovano poplavljeno v času žetve ali spravila. ${ }^{7}$ Zgornje polje je zaradi plitve ornice hitro odcedno in je zato bolj podvrženo suši, med tem, ko je spodnje polje večinoma vlažnejše in bolje kljubuje suši. Vladala je torej izrazita dvojnost, posledično tudi v dodatnih znanjih potrebnih za uspešno obdelavo. Staro pravilo, ki je nekdaj npr. veljalo na Bre-

Informator EKC, VER, TTD, STM. 
gah, se glasi »gor 12 , dol $16 \ll^{8}$, ki pove kako globoka naj bo brazda $(\mathrm{cm})$ v zgornejm in spodnjem polju, da s preglobokim oranjem v plitvo ležečo prodno osnovo ne bi trajno uničili njive.

V času do leta 194I, ko je bilo preživetje večine tukajšnjih prebivalcev odvisno skoraj izključno od uspešnosti poljedelstva, se takšna možnost gospodarjenja v obeh ekoloških conah izkazuje kot ključna, sama lega naselbin pa namerna, premišljena in predvsem ključna za preživetje. Vstran gospodarskemu vidiku, lahko poselitev robov poplavne ravnice pomeni tudi izraz identitete naseljencev (Evans 2003, 90). Navkljub temu pa so obrečne poplavne ravnice $v$ modernem gospodarstvu navadno obravnavane kot prostor drugotnega pomena (Brown 200I, 282).

$\mathrm{Za}$ razumevanje pomena človekovega bivanja na stiku dveh ekoloških con in gospodarskega pomena poplavne ravnice, je izjemno prikladno dejstvo, da so kar štiri od šestih obravnavanih vasi (z izjemo G. in D. Skopice), imele leta 1824 jedra svojega spodnjega polja skoraj v celoti znotraj k. o. Drnovo. Ta s svojim obsegom -842 ha spodnjega polja na razdalji do Save in le z 230 ha zemljišči na zgornjem polju - posredno izpostavlja in poudarja obrežno naravo obravnavanih vasi, hkrati pa v celoti zaobjema njihov gospodarski radij v poplavni ravnici. Cenilni elaborat franciscejske katastrske izmere za k. o. Drnovo, je posledično dober vir vpogleda za razumevanje gospodarjenja $\mathrm{v}$ poplavni ravnici. Tam izvemo, da so najboljše njive $\mathrm{I}$. in 2 . kakovostnega razreda vzorčili le $\mathrm{v}$ spodnjem polju (v poplavni ravnici), med tem, ko so njive 3 . kakovostnega razreda beležene $\mathrm{v}$ zgornjem polju. Za razliko od zgornjega polja, so v spodnjem polju, poleg njiv, obstajali še različni kakovostni razredi travnikov in pašnikov. Pašniki nasploh najbolj karakterizirajo območje naše obravnave, saj jih na zgornjem polju skorajda ni bilo. Obstajala je tudi kategorija - trike (Rihter 2015, 16-27). Trike (Trischacker) so bila zemljišča, kjer je šlo za izmenjevanje njive in pašnika na istem mestu (Seručnik 2009, 494) oz. za daljšo dobo počivanja zemljišča, kot pri običajni prahi (Valenčič
1970, 132; prim. Novak 1947, IO-II). V poplavni ravnici je bilo takšnih zemljišč za dobrih 85 ha in sicer na prehodnih območjih med strnjenimi pašniki in njivami, kjer je šlo za naosemletni kolobar brez gnojenja. Prvo leto so sejali proso, drugo leto oves in sirek, tretje leto so površino uporabljali kot pašnik in tako še nadaljnih pet let, ko se je kolobar ponovil (Rihter 2015, 19-25). V zvezi s kvaliteto spodnjega polja je izpoveden podatek za k. o. Drnovo, ki se nedolgo (leta i833) pred zemljiško odvezo, omenja kot ena redkih k. o. na območju davčnega okraja Šrajbarski turn, kjer so v dobi uvajanje koruze, le-to sejali v večjih količinah (Britovšek 1964, 215-217). Pomenljivo pa je, da se je sejala praviloma na najkakovostnejših njivah I. in 2. kakovostnega razreda, torej skoraj izključno na spodnjem polju, ki je dajalo največji pridelek (Rihter 2015, 17-19). S tem je spodnje polje na našem prostoru postalo ključen nosilec tudi pri uvajanju novih poljščin, ki so trajno spremenila dotednje poljedelske prakse. Tako naprimer že v sosednji katastrski občini Senuše, koruza v istem času sploh še ni bila del katastrske cenitve, saj so jo sejali le v manjši meri (Rihter 2014, I5).

Retrogradna analiza zemljiškega katastra za vas Drnovo (Rihter 2015), je pokazala, da so bila najstarejša in najkvalitetnejša obdelovalna jedra zgornjega in spodnjega polja med predhodnjice nekaterih današnjih kmetij razdeljena v uravnoteženih deležih. Po nastanku relativno najmlajše kmetije so v teh jedrih praviloma odsotne ali pa nastopajo prostorsko povsem obrobno, nekatere pa si v i9. stoletju krčijo dodatne deleže na izrazito mladih, obrečnih tleh globoko v poplavni ravnici (Rihter 2015, I-I63). Zemljišč naj bi namreč v nižinskem uradu Krškega gospostva primanjkovalo že v zadnji tretjini I6. stoletja (Koropec 1977,48$)$. Isti čas je zabeleženo tudi največje število govedi in konj, ravno v vaseh, ki obdajajo poplavno ravnico ob levem in desnem bregu Save (Koropec 1977, 48-49). Sklepamo lahko, da je bilo tako zaradi bogatega pašnega in vodnatega zaledja, ki so jih te vasi, za razliko od preostalih, imele $\mathrm{v}$ poplavni ravnici. 


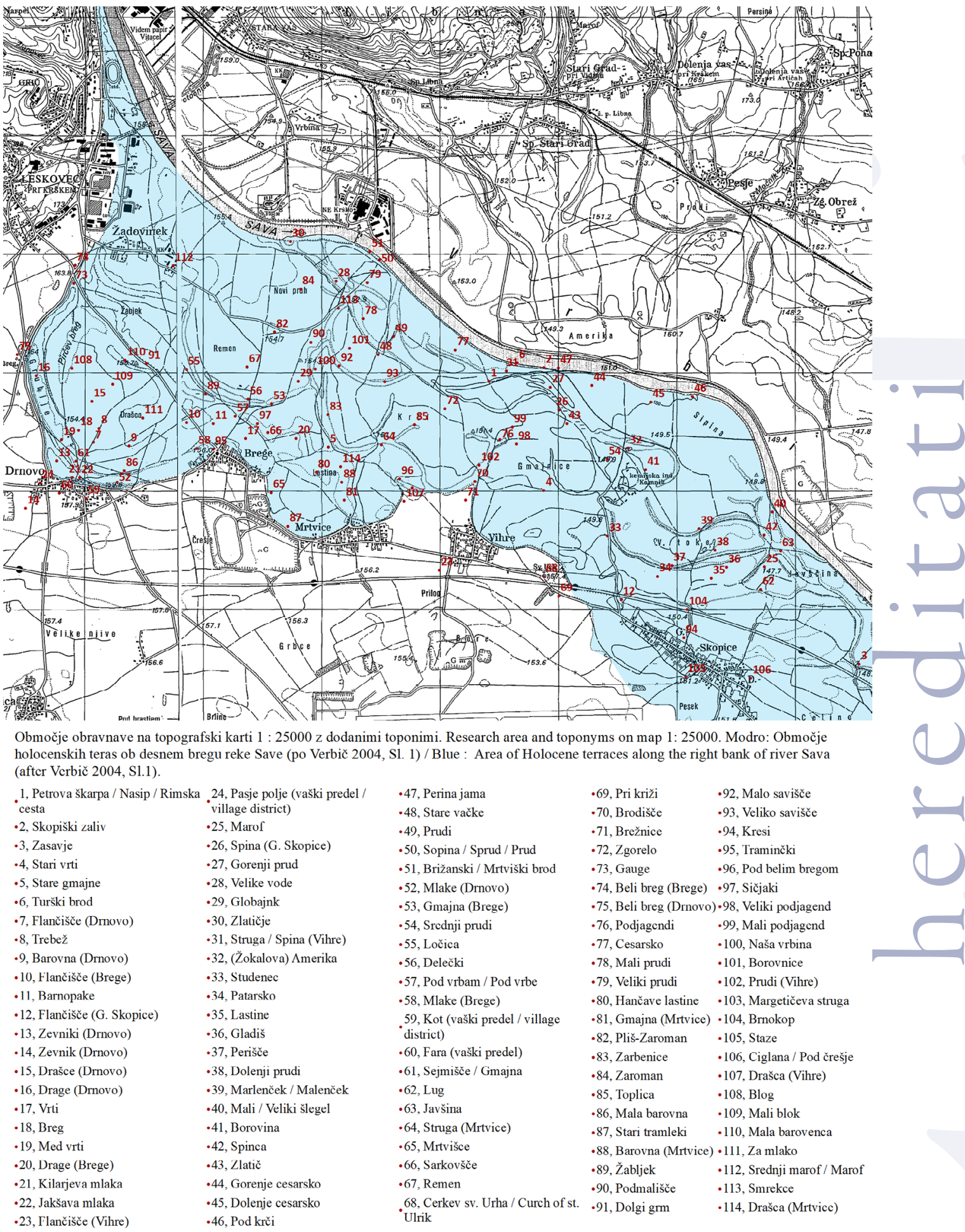

Slika r: Prostor obravnave. / The territory of inquiry. 


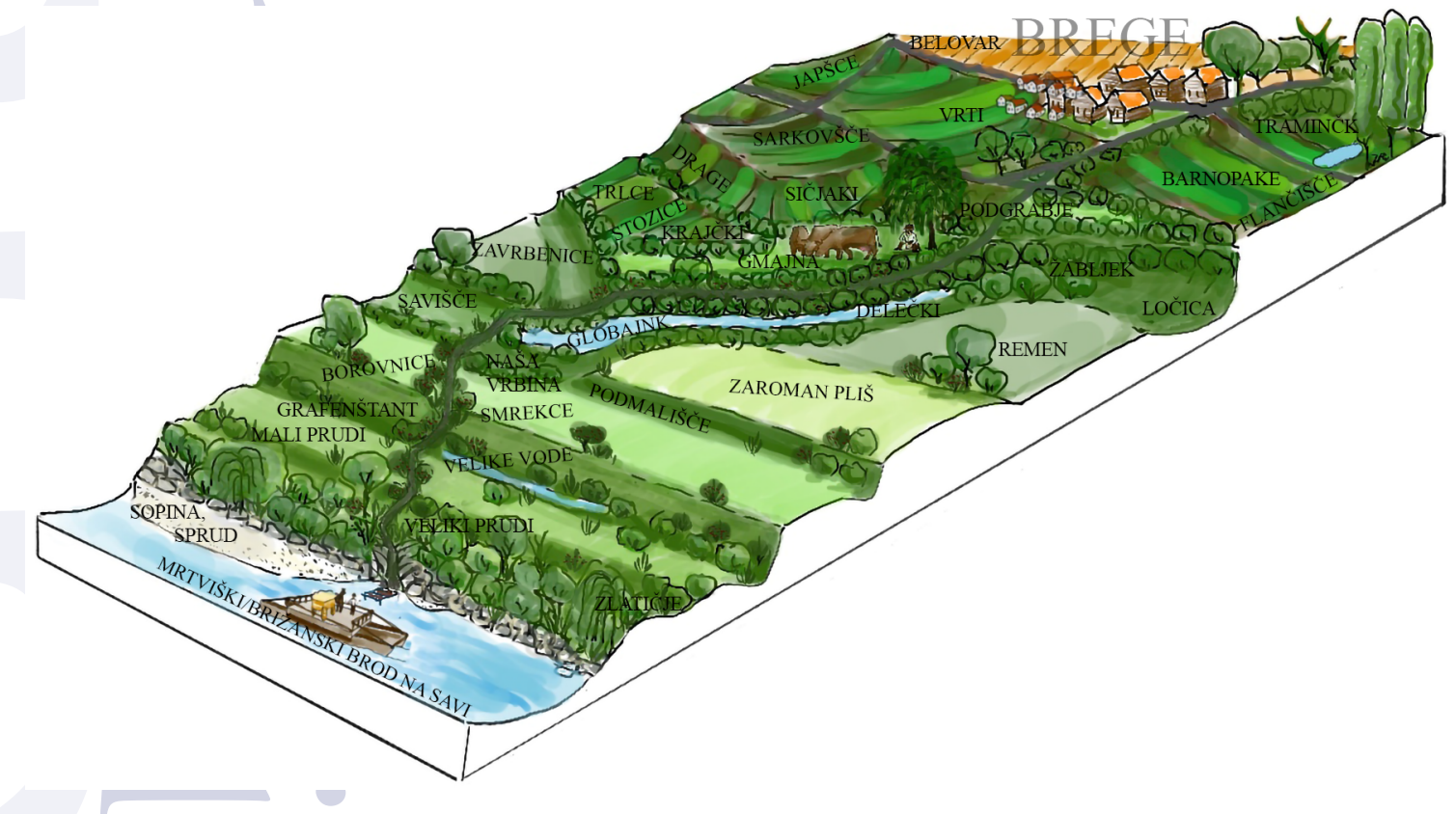

Slika 2: Ilustracija presekov savskih teras in idealizirana podoba vaškega polja vasi Brege do reke Save v prvi polovici 20. stoletja. / Idealized illustration of terraces of the Sava river and its cross-section in the area of fields that belonged to the Brege village as they were in first half of $20^{\text {th }}$ century (ilustrirala: Janja Rihter).

Gre za ekološko povsem različna svetova; med tem, ko je bilo zgornje polje v začetku i9. stoletja' skoraj v celoti namenjeno zgolj njivam, bi spodnje polje lahko imenovali tudi kot prostor med vasjo in reko, kjer je poleg izkrčenega sveta njiv, travnikov in pašnikov do srede 20. stoletja obstajalo še veliko drugih naravnih oblik značilnih za vlažno/mokro okolje; npr. mrtvice, vlažni travniki, logovi, loke in t. i. vrbine na nekdanjih prodnatih otokih (Sl. 2). Poplavna ravnica prepredena s starimi strugami reke Save ni bila nikoli povsem izkrčena v polje, krčenje obdelovalnih površin pa poteka še danes (Rihter 2015, 59-60; sl. 23 in 24).

$\mathrm{Na}$ ravni kmečkih gospodarstev, je človekove dejavnosti v poplavni ravnici težko ločiti na agrarne in neagrarne. V skoraj vseh primerih je šlo za kombinacijo obojega $\mathrm{z}$ namenom zagotavljanja uspešnejšega preživetja. Različne dejavnosti so bile močno prepletene tako prostorsko kot časovno. V opish v nadaljevanju bo večkrat razvidno, da so $\mathrm{v}$ poplavni ravnici sočasno potekala številna, povsem različna dela, npr. paša, napajanje, ribolov, pranje tkanin in spiranje žita.

$\mathrm{V}$ nadaljevanju prehajamo na konkretne opise človekovih dejavnosti v poplavni ravnici.

\section{Poplavna ravnica kot gospodarsko zaledje kmečkih gospodarstev}

Predstavitev pomena poplavne ravnice pričenjamo s tamkaj površinsko eno najmanjših, obdelovalnih enot im. - flančišče. Ta s svojo izrazito navezanostjo na poplavno ravnico, pravzaprav najbolj pooseblja in združuje bistvo življenja na robu dveh ekoloških con in poudarja njegov pomen za preživljanje človeka. Predvsem pa kaže na njegovo premišljeno prostorsko palnirano kmetijstvo. 


\section{Flančišča}

Flančǐšč $a^{\text {I0 }}$ so bila najmanjše obdelovalne enote izven domačega dvorišča, izrazito vezane na pašnike in njihova obrobja $\mathrm{v}$ poplavni ravnici. Navadno jih neposredno izdaja mikro toponim Flančišče, ki se nahaja znotraj območja, ki ga sicer pokriva nek drug, površinsko obsežnejši toponim. Flančišče/a niso enaka vrtu oz. gredi, ki je bila vezana na domače dvorišče, niti njivi $s$ (po)vrtninami, t. i. zeljnikom, ki je po sestavi posevkov dejansko razširjen vrt, le da se lahko (od doma) nahaja na do nekaj sto metrov oddaljeni rodovitnejši njivi. Flančišča zato morda najbolje opredeljuje izraz gojitveni vrt, kot prostor za vzgojo in množenje rastlin, ki so jih kasneje presajali na njive/vrtove na različnih delih polja.

Flančišča so obujali v zgodnji pomladi, na njih pa so največ gojili sadike zelja in pese. $V$ času po presaditvi na njive (Gl. Ilovica), so flančišče, do drugega leta povsem opustili, nato pa zopet iskali novo rodovitno mesto za sejanje, občasno pa so ponovno obudili tudi staro mesto. Pri tem je šlo za izkoriščanje določenih predelov pašnikov na najrodovitnejših mikrolokacijah, ki jih danes lahko naznanja toponim Flančišče (Rihter 2015, 24-25). Pogosto je šlo za poraščene predele, ki jih je bilo potrebno v celoti ali deloma izkrčiti. ${ }^{I I}$ Preko do slej zbranih podatkov smo flančišča kot toponime odkrili na Drnovem, Bregah, Vihrah in na Gorenjih Skopicah.

$\mathrm{Na}$ Drnovem je bilo Flančišče mikrotoponim za rodoviten prostor $\mathrm{v}$ sklopu ledine, ki jo opredeljuje toponim Trebež in njene soseščine, znotraj več hektarjev velikega osrednjega vaškega pašnika Barovna.

Tu so imele ženske flančišča, vsaka eno gredo po $5 \times 5 \mathrm{~m} .{ }^{\mathrm{I2}}$ Vsak je imel eno gredo, kot soba veliko, tam so si posejale flance, pa peso, po tem pa so tisto pukale in presajale po njivah. ${ }^{\mathrm{I3}}$

Io Iz nem. Pflanze, kot rastlina ali narečno flanc. V obravnavanih vaseh je flanc sinonim za sadiko zelja.

Informator VMA, TTR.

I2 Informator RVA

13 Informator RVA
Na Bregah je toponim Flančišče sčasoma zaobjel prostorsko nekaj hektarjev velik nekdanji pašnik na meji z drnovsko Barovno. Na robovih in v notranjsoti tega pašnika so izpričana flančišča tako na Bregah (Sl. 2), kakor na Drnovem. ${ }^{14} \mathrm{Na}$ meji med Barnopakami in Flančišči so v daljšem pasu izpričani majhni vrtovi za sajenje pese in zelja za kasnejši razsad, ${ }^{15}$ kar prav tako ustreza flančiščem.

Iz Gorenjih Skopic je znan naslednji opis:

Flančišče. Spomin mi seže v pretekla leta,
nazaj v mojo mladost, ko si je naša mama v
zgodnji spomladi, kot so včasih rekli - ko se
ptički ženijo, naložila samokolnico dobrega
gnoja in ga peljala po makadamski cesti do
konca vasi, in še ven. Tam smo kraj imenova-
li Flančišce. Bilo je v grmovju. Rasel je črni
trn. Tam je imela vsaka hiša gredico, da so si
spomladi posejali flance za zelje. Trnje okoli
je z vinkom obsekala, zemljo prelopatala in
zagnojila. V velikem tednu, na veliki petek,
je vzela seme, ki si ga je sama vzgojila, vzela
grablje in šla posejat seme. Ko pa je prišlo ob-
dobje za sejanje, je gospodar vzel koš in šel
populiti flance in jih prinesel na zelnik, kjer
smo flance posadili z lesenimi klini. Po tem
smo pazili, da njiva ni ozelenela. Če je še bilo
vreme naklonjeno, je bilo zelja, da smo na-
polnili polno vinsko kad. Bilo ga je za celo
leto. (Vodopivec zoo8, p. 30 ).

Gorenjeskopiško Flančišče je kasneje, po razdelitvi skupnih površin, zajemalo »27 parcelic, velikostipo 2-3are. $\ll^{16}$

Flančišče torej ( $v$ današnjem smislu) posnema domačo rodovitno in gnojeno vrtno gredico, vendar na dislociranem koščku zemljišča, navadno znotraj večjega pašnika, kjer se vsako leto išče in izkorišča spočite in rodovitne predele, $\mathrm{ki}$ so nastajali z grmovno preperlino v povrhnjici. Bistvena prednost tako odbranih površin je njihova rodovitnost, ne da bi jih bilo potrebno gnojiti z domačim gnojem, ki ga je vselej primanjko-

I 4 Informator VMA, FSI, VER, RVA

I5 Informator VER

I6 Informator XSX-MST 
valo. Varstvo rastlin pred živalmi, predvsem pred pašno živino, je zagotavljala okoliščina krčenja za flančǐ̌če v grmovju. Za tako ograjena flančišča vemo iz Drnovega in z Breg. Kaže, da o njihovem značaju in razprostranjenosti govorijo tudi imena sama, v odnosu do površine, znotraj katere velja toponim. Na Bregah je več hektarjev velik predel pašnika med ljudmi enotno poimenovan Flančišči, torej Flančišča. To je moč razložiti $s$ tem, o čemer priča že samo izročilo in pričevanja, in sicer, da so bila na tem območju flančišč razkroplejena po različnih predelih celotnega območja, pa tudi na robovih. Na Drnovem so flančišča obstajala na starem, več hektarjev velikem pašniku ledine Barovna, znotraj katerega je bila izkrčena ledina Trebeži, znotraj te pa velja toponim Flančišče. Vendar je bil ta prostor dovolj velik, da je po potrebi omogočal menjavanje gredic. Primer iz G. Skopic že kaže primer, kako so starejša migrirajoča flančišča prerasla $v$ stalne gredice, ki so jih v 1930-tih gnojili, kar je povezano z že razparceliranimi deleži nekdanjega skupnega pašnika.

Bistven poudarek opisanih flančišč je torej $\mathrm{v}$ njihovi legi, in sicer na rodovitnem in vlažnem območju spodnjega polja ter njihovi vlogi v procesu pridelave zelja, ki je tu, kakor tudi marsikje drugod, pomenilo steber prehrane predvsem hladnega dela leta.

Na flančiščih pridelane sadike so po razsaditvi zahtevale nadalnjo nego na primerno pripravljenih in kvalitetnih zemljiščih. S tem že prehajamo na drugo obliko rodovitnih zemljišč, ki so se prav tako nahajale v spodnjem polju, kamor so običajno v kolobarju za junijsko žetvijo žita, na strnišče prenseli sadike - flance. To so njive zelniki oz. njive s (po)vrtninami. Takšne njive imajo tod značilna imena Zevniki, Drage, Drašce ali Vrti. ${ }^{17}$ Sledi izbran primer ledine Zev-

Tu omenimo, da toponimi Zevniki in Flančišče - obstajajo tudi v zgornjem polju (npr. Vihre in Drnovo), kjer so izvajali iste dejavnosti, kot v spodnjem polju. Vendar retrogradni pregled razvoja zemljiških deležev kmetij, ki so tam nekdaj obdelovala zemljišče, pokaže, da gre glede na ostale kmetije v vasi, za izrazito mlade ali vsaj relativno mlajše kmetije. Zanje, v času njihovega formiranja, v spodnjem polju ni bilo več prostora za pridobitev zemljiških deležev. Prav te kmetije si zato (čeprav redkeje), po vzoru iz spodnjega polja, urejajo zelnike/flančišča $v$ izbranih in najrodovitnejših predelih zgornjega polja. Npr. na Drnovem ima relativno najmlajši vaški pre- niki na Drnovem, kot najtipičnejše oblike njive s (po)vrtninami na obravnavanem območju, kjer so pridelovali zelje v stopnji po razsadu iz Flančišč. Poglejmo.

\section{Zelniki, Zeuniki}

Med najtipičnejše njive s povrtninami na Drnovem sodi ledina Zevniki na prvi savski terasi pod vasjo. O tamkajšnji izjemni rodovitnosti priča izročilo o pridelovanju zelja, ki ga danes nekateri imenujejo staro zelje ${ }^{\mathrm{r8}}$ in pričevanja o posebnem tretiranju teh njiv (Rihter 2015, 25). Količino pridelanih zeljnih glav s teh njiv so merili v številu vozov oz. v konicah. Omenjajo se več sto litrske kadi kisanega zelja ter prav tako tudi prodaja svežih zeljnih glav v bližnjem hribovju, npr. v smeri Rake in drugih delov Krškega hribovja. ${ }^{19}$ Pričevanja o velikem pomenu zeljnega pridelka na Drnovem (npr. Počkar 1998, 287) ter o visoki stopnji znanja in dovršene ter obsežne pridelave zelja, govori podatek iz leta 1862 , ki sicer nekoliko vzneseno pravi, da naj bi v drnovskem »hafnu«, tj. na današnji ledini Zevniki, pridelali dovolj zelja za vso Ljubljano (Rihter 2015, 25 ). Razširjeno in uspešno pridelavo zelja na Drnovem omenja tudi kronika sosednje župnije Videm ob Savi, iz leta ı880, ki govori, da na Vidmu zeljnih sadik niso vzgajali sami, temveč so jih kupovali v vasi Drnovo, v leskovški župniji na Kranjskem, po 30 do 50 krajcarjev za Ioo kosov (Ripšl 2007, 154).Zevnikom po kvaliteti primerljiva ledina za pridelavo zelja in drugih povrtnin je bila na nasprotnem bregu stare struge, na ledini Breg, prostor med njima je nosil zgovorno ime - Med vrti. Na Bregah so tem istim namenom, za razsad sadik služile ledine Vrti, Barnopake in Drage. V vseh primerih je razvidna Ioo do naj-

del im. Pasje polje, svojo ledino Zevnik, južno od vasi v zgornjem polju. Enako najdemo južno od vasi ledino Flančišče v vasi Vihre. Poglavitno jedro površin za flančišča in zelnike je tod nedvomno vezano na spodnje polje.

I8 Tako so pravili neki vrsti zelja z odličnimi lastnosti tako za solate kakor tudi za kisanje. Imelo naj bi drugačne lastnosti od t. i. Ljubljanskega zelja (Rihter 2015,25) in ni enako t. i. varaždinskemu zelju. Ta vrsta zelja je po mojem poznavanju ohranjena le še na nekaterih drnovskih kmetijah, seme pa je vsaj v enem primeru preživelo celo nemško okupacijo, saj so ga izgnanci v času internacije v Nemčijo vzeli sabo in je bilo po vrnitvi v uporabi še naprej.

19 Informator TTR, STM, MIM, idr. 
več 200-metrska oddaljenost od vasi. Takšne njive so bile deležne tudi izdatnejšega gnojenja in nasploh večje pozornosti.

Tako so na Drnovem usedline iz vaške Kilarjeve ali Jakšave mlake uporabljali prav za gnojenje dveh za pridelavo vrtnin najpomembnejših ledin Zevniki in Breg (Rihter 2014, 39).

Iz zelnikov v spodnjem polju se sedaj prestavimo v vasi, na stare savske ježe, oz. na vaška dvorišča, kjer se dvojnost življenja na meji obeh svetov pokaže, tokrat $\mathrm{v}$ še manjši obliki kot pri ravnokar opisanih flančiščih in zelnikih, to je v t. i. zgodnjih in poznih gredah ali vrtih. Tudi ti so bili plod naravnih danosti in izbrane lege naselbin ter mikrotopografije posameznih dvorišč.

\section{Zgodnje in pozne grede/vrtovi}

Vpogled v mikrotopografijo planiranja posevkov na meji obeh ekoloških con, nam dajejo tudi pričevanja o hišnih vrtovih v vasi Brege, kjer se naselbinski deli severne polovice vasi deloma usedajo na pleistocensko teraso/zgornje polje, s spodnjimi deli dvorišč pa proti severu že prehajajo $\mathrm{v}$ poplavno ravnico/spodnje polje, značilno imenovano Vrti (Sl. 2). Vrtovi, kot deli spodnjih koncev dvorišč, so bili ograjeni s pletenimi plotovi iz vejevja, v katerih so bili značilni prehodi im. prelozi. Severna polovica vasi Brege, torej ta, ki je neposredno mejila na spodnje polje, je imela vrtove na senčni in vlažnejši, prvi spodnji terasi (Sl. 2). Južna polovica vasi, onkraj vaške ceste, pa je že v celoti stala na sončnejši, pleistocenski terasi, a s prepustnejšo, prodnato prstjo. Bistvo razlike $\mathrm{v}$ legi obeh vrtov strne informator $\mathrm{z}$ severnega dela vasi: »V južni polovici vasi je imel vsak svojo gredico skonca dvorišča, tam je bilo prej za saditi spomladi. Ti so imeli vse poprej, mi pa vse kasneje. Njim pa je ob suši vse prej vzelo kot nam. $\ll^{20}$ Po tem principu so torej tod ravnali tudi pri vseh drugih kulturah na večjih njivskih površinah. ${ }^{2 I}$ $\mathrm{V}$ 20. stoletju vsakdo seveda te možnosti ni imel. Mnoge po nastanku mlajše kmetije namreč niso imele deležev v spodnjem rodovitnejšem polju (prim. Rihter 2015, 34-52 in Sl. 16). Princip »po-

\footnotetext{
20 Informator VER

2I Informator VER, TTR, RAD, FSI, idr.
}

znega vrta« (prim. Počkar 1998, 58-60) oziroma njiv, ki so vzdržale sušo ter tako zagotavljale pridelek, je bil tu tesno povezan s poplavno ravnico. Resen strah pred sušo, ki se najsiloviteje in hitro pokaže predvsem na zgornjem, peščenem polju (prim. Teppey I97I, 22) slikovito opiše naslednji stavek, ki se nanaša na zgornje polje: »Pri nas je namreč samo takrat dobra letina, ako naše brate preko Sotle zaliva voda, to se pravi: Ako poleti ali vsaj v času glavne rasti dvakrat ali trikrat na teden dežuje. « (D. S. I930, II).

O pripravnosti aluvialnih tal za intenzivne gojitvene potrebe na tem področju prvič slišimo v letu I893 ko so ob Savi pri D. Skopicah želeli postaviti deželno trsnico - po napadu trtne uši ki bi proizvedla 0,5 mio cepljenih ameriških trt letno. ${ }^{22}$ Po drugi svetovni vojni je trsnica pričela delovati, in sicer na ledini Marof. ${ }^{23} \mathrm{Na}$ tem mestu zgolj omenimo kmetijsko in gospodarsko intenziviranje poplavne ravnice, ki je sledilo v prvih dveh desetletjih po koncu 2. svetovne vojne in ki je vzpostavilo obsežne monokulturne nasade topolov in njiv s krmnini in semenskimi rastlinami na obeh bregovih reke save med Krškim in Brežicami.

Prisotnost ali bolje rečeno neposredna bližina mokrega sveta je bila za preživetje v ravnici ključnega pomena. Poglejmo sedaj pobliže različne vidike življenja z mokrim svetom.

\section{Mokri svet Vrbine}

Mnogo najnižjih predelov poplavne ravnice so $\mathrm{v}$ I9. stoletju uporabljali kot pašnike (Rihter 20Io, 34). Pašniki so tod ob izteku fevdalne dobe zajemali nekaj sto hektarjev različnih kakovostnih razredov. Med njimi so bile tudi mrtvice in območja s talno vodo na površju. ${ }^{24}$ Skupnih pašnikov (kot katastrsko vodene kulture) na zgornjem polju v k. o. Drnovo, razen redkih izjem tedaj

\footnotetext{
22 Dolenjske novice (1.5. 1893).

23 Informator ZXF.

24 Glej franciscejski kataster za k. o. Drnovo - grafični del (mapni list VI), abecedni seznam posestnikov, zapisnik zemljiških parcel in cenilni elaborat; za k. o. Krška vas - zapisnik zemljiških parcel, abecedni seznam posestnikov in in cenilni elaborat ter za k. o. Leskovec pri Krškem - grafični del (mapni list VII), abecedni seznam posestnikov, zapisnik zemljiških parcel in in cenilni elaborat (gl. Literatura).
} 
skorajda ni bilo (Rihter 2015, 37). Sredi prve polovice 20. stoletja so bile največje pašne površine, še vedno omejene na poplavno ravnico. Med njimi so bile ponekod še vedno odprte vodne površine $s$ talno vodo in tudi mrtvice. Različne oblike vodnih površin so pestrile okolico, $v$ okviru paše pa so bile pomembne predvsem zaradi napajanja živine (Vodopivec 2008, p. 72).

Do leta 194I je obstajala učinkovita izraba mokrega sveta tam, kjer so bile vodne površine še prisotne. Glede na oddaljenost od naselbinskih delov je šlo po naši presoji (s kriterijem možnosti za koriščenje) za 4 skupine vodovja, ponekod brez izrazitih meja pri prehodu iz ene oblike v drugo:

I. vodne površine $\mathrm{v}$ neposredni bližini vasi ali znotraj njenega obsega (vaške mlake, talna voda),

2. vodovje znotraj obsega vaškega polja ali na njegovem obrobju (talna voda, stalni (potok) in občasni izviri),

3. voda v oddaljenih pašnikih Vrbine (mrtvice) in

4. glavni tok Save (tekoča voda).

$\mathrm{V}$ vseh naštetih conah so se odvijale različne oblike paše in številne druge dejavnosti, ki jih predstavljamo v nadaljevanju.

\section{Mokro godenje lanu}

Mokro godenje lanu v mrtvici je bilo v obravnavanih vaseh do slej izpričano le na G. Skopicah na ledini Spina, kjer so to opravilo dokumentirano izvajali še v 1930-tih letih. Povsod drugod so v tem času izvajali le še vlažno godenje lanu na travnikih ali njivah v nesposredni bližini vasi. To povezujemo $\mathrm{z}$ dejstvom, da so mrtvice $\mathrm{v}$ večjem številu tedaj obstajale le še na skopiškem. Danost so $s$ pridom izkoriščali, seveda premišljeno do drugih odprtih vodnih virov, v katerih so napajali živino ali prali tkanine. Znano je namreč, da namakanje lanu poleg smradu, povzroča tudi toksikacijo vodnih virov (prim. Hoffmann 1996 , 645; 2008, 48). Tozadevno je pomembno, da je na Spini, poleg ene večje vodne površine, obsta- jalo še nekaj manjših, nepovezanih vodnih površin ob poti na Gorenje prude:

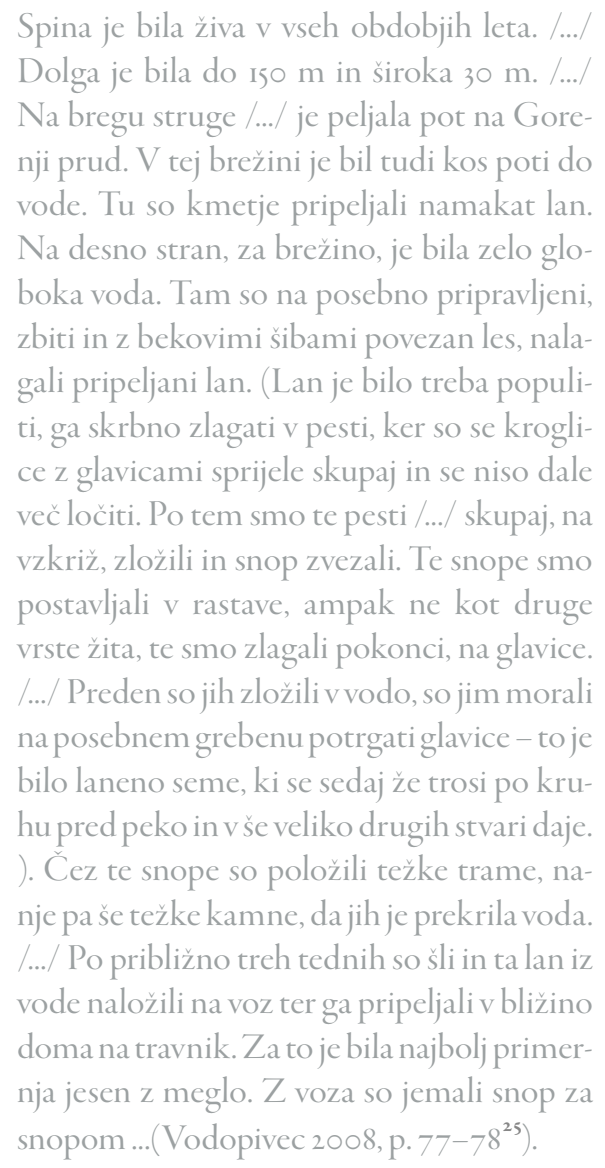

$\mathrm{S}$ posevki lanu in konoplje so praviloma $\mathrm{v}$ vseh vaseh povezane tudi skoraj izključno njive v poplavni ravnici.

\section{Ribolov}

$\mathrm{O}$ t. i. športnem ribolovu v času pred 1945 na območju naše obravnave, ne poročajo nikjer. Savski ribolov je bil v drugi četrtini 20. stoletja tod predmet zakupa, z njim pa so se ukvarjali različni posamezniki. $V$ obravnavanih vaseh so to bili brodniki in tisti z malo ali nič zemljišč, vendar ne množično. Iz vasi bližje regulirani Savi (Brege in Mrtvice) je poimensko znanih nekaj ribičev, ki so lovili ribe za blagovno menjavo. Navkljub temu je bilo na individualni ravni posameznih

25 Neobjavljeno delo (gl. Literatura). Navedeni odstavek je bil objavljen pri Rihter (2010, 25-26). 
kmetij obvladovanje številnih ribolovnih veščin zabeleženo marsikje.

Poglejmo sedaj ugotovitve o stanju voda in zmožnostih za ribolov $\mathrm{v}$ vaseh od zahoda proti vzhodu. Na Drnovskem spodnjem polju zaradi nestanovitne narave zastalega vodovja (nihanje talne vode) in drugih dejavnikov (tacanje živine in prisotnost domače perjadi) stalno prisotnih rib v 20. stoletju ni bilo nikjer. $\mathrm{Na}$ območju Breg smo glede na število mest $s$ stoječo ali zastalo vodo (npr. Velike vode, Globajnk ali Zlatičje), pričakovali, da bomo tam našli pričevanja o prisotnosti rib in njih ribolovu (Rihter 20IO, 3I), sedaj pa je na podlagi dodatnih pričevanj že jasno, da tu v tridesetih letih preteklega stoletja ni bilo rib, razen krajša ali daljša obdobja za poplavami, kjer je šlo za naplavljene ribe, ki so jih za hrano seveda pobirali iz kotanj. ${ }^{26} \mathrm{Tu}$ kajšnji manjši obseg talnega/zastalega vodovja in s tem povezani nestanovitni življenjski pogoji, so onemogočali preživetje in reprodukcijo ob povodnji naplavljenih rib. Vsa pričevanja o ribolovu na brižanskem, so torej že vezana izključno na glavni savski tok. To je razvidno tudi po izpričanih ribolovnih vrstah v vasi Brege: somi, veliko belic velikosti do $30 \mathrm{~cm}$ in občasno sulci (Rihter 20IO, 3I). Nasprotno pa na Vihrah, v t. i. vihranski vrbini, kjer so bile mrtvice tedaj še ohranjene (npr. na ledini Struga/Spina), še zlasti pa na več mestih na območju obojih Skopic, v t. i. skopiški vrbini, je bil pravi ribolov v mrtvicah še zelo razširjen. O vodnatosti in življenjskih pogojih tamkajšnjih mrtvic pričajo omembe ribjih vrst in temu prilagojena ribiška oprema, kakor bomo videli v nadaljevanju. Poglejmo sedaj natančneje pričevanja o ribolovu v posameznih vaseh, od tistih z bolj osušenimi mrtvicami, kjer so ribolov izvajali le še neposredno ob reki (Brege), do tistih, ki so v okviru svojega polja še imeli mrtvice (Vihre, G. in D. Skopice).

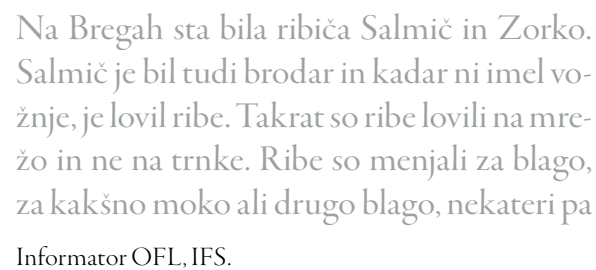

\section{so jih že prodajali, npr. Salmič. Ribič Zor- ko si je sam pletel ribiške mreže. Lovili so na križ. Dobili so mrene in ploske, včasih tudi kakšnega soma. Največ je bilo ploskov. ${ }^{27}$ Zorko je lovil tudi s sakom, največ je bilo ploskov, ki pa so vsi po nafti smrdeli. ${ }^{28}$ V̌́a- sih so lovili tudi menke. ${ }^{29}$}

$\mathrm{Z}$ ribolovom so se na Bregah pred drugo svetovno vojno ukvarjali poleg Zorka, še Kočevar in Judež.

\section{Ker so bili tabarharji so si na ta način služili kruh. Mama so od njih kupili ali menjali ribe za moko. Bile so to ribe velikosti do $20 \mathrm{~cm}$ in so imele veliko kosti. ${ }^{30}$}

$\mathrm{V}$ vas je pripeljal žive $\mathrm{v}$ posodi napolnjeni z vodo. ${ }^{3 \mathrm{I}} \mathrm{Na}$ Drnovem, pravijo, da so bile savske ribe malokdaj $25 \mathrm{~cm}$ velike, z njimi pa jih je zalagal stari ribič Zorko, im. tudi Zorkac z Breg, ${ }^{32} \mathrm{ki}$ je lovil z mrežo. ${ }^{33}$ Brižani so pobirali/lovili naplavljene ribe v starih strugah tudi po poplavah.

Podobno je bil ribolov v vasi Mrtvice priložnostno vezan na predele $\mathrm{v}$ starih strugah, sicer pa ob glavnem toku:

\section{V kakšnih globanjkih ali tolmunčkih so lo- vili, kjer je ostalo kaj rib. Šularu Martenk je imel tudi nekakšne hakle, pa šivanko lese- $\mathrm{no}^{34}$ (prim. Sl. 3).} $\downarrow$

(a)

(

Pletenja mrež so se pri nejm učili še v povojnem času. ${ }^{35}$ Sicer pa je bil omenjeni mož tudi eden izmed brodarjev na brižansko-mrtviškem brodu, ki je v Vrbini, najverjetneje v bližini broda, po pričevanju živel v nekakšni zemljanki. ${ }^{36}$ Splošno znan pa je bil tudi kot ribič. Pri brodu je bila kasneje tudi brodarska hišica.

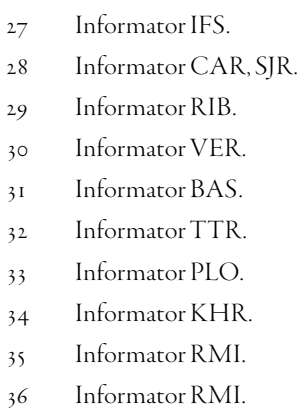


V Vihranski vrbini je bil, za razliko od do slej omenjenih področij, že možen ribolov v mrtvici celo še nekaj časa po 2. svetovni vojni:

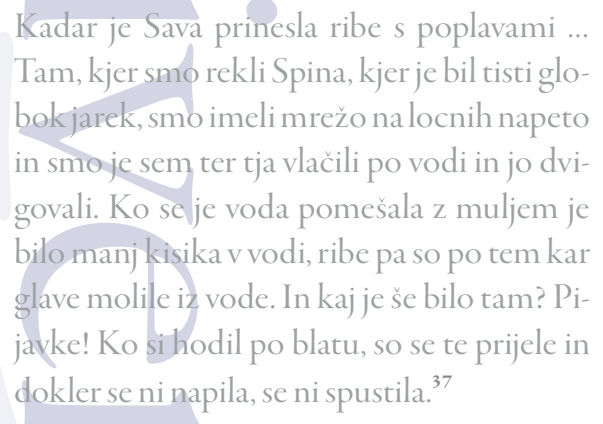

Ribolovni tereni na skopiškem so bili za razliko od omenjenih vasi mnogo bolj pestri. Ribolov je bil mogoč na številnih mestih, tako ob Savi, kakor tudi v mrtvicah, npr. na predelu Spina in Amerika, predvsem pa na ledinah vzhodno od predela Studenec. To območje se je polnilo s tamkaj (na Studencu) izvirajočo vodo, ki je v obliki potočka odtekala po opuščenih savskih strugah severno od ledine Patarsko, Lastine in Gladiš, in sicer preko ledin: Perišče, Dolenji prud, Marlenček in Šlegel (Mali/Veliki), ${ }^{38}$ kjer se je izlival v Savo (Rihter 20IO, 27 in 3I). Morfologija starih savskih strug na njegovi poti je narekovala ustvarjanje blatnih tolmunov in plitvih prehodov s tekočo vodo. Za prve poročajo o izobilju rib in pijavk, na drugih pa so bili zaradi plitvin ustvarjeni prehodi, ki so vodili v notranjost Vrbine, $\mathrm{k}$ reki. Prehode za pešce so kazali na dnu položeni večji kamni. Kot taki pa so bili priročni za pranje tkanin (stepanje), kar so tu dokumentirano tudi izvajali (gl. Pranje...). Potoček je presahnil pred več kot pol stoletja, vendar po večjih povodnjih, ko se za kratek čas poustvarijo (v oziru vodostaja v zaledju ravnice) nekdanjim podobne razmere, se na ledini Studenec ponovno vzpostavi izvir, ki po okoli 3 tednih presahne, npr. povodenj 2010 in 2012. Voda priteka (brizga) pod pritiskom navpično iz dna struge, navadno iz ene večje luknje (globina $120 \mathrm{~cm}$, širina $0,5 \mathrm{~m}$ ), ki se pri tem oblikuje ter iz nekaj manjših v neposre-

37 Informator PAT.

38 Informator RCD dni bližini ${ }^{39}$. Prav takšno stanje pa opisujejo tudi ljudski spomini na Drnovem, ob pričetku zalivanja stare struge pod vasjo (Gl. Lomljenje ...).

$\mathrm{Na}$ ledinah vzhodno od Studenca so lovili krape in šlaje (linj; Tinca tinca) tako, da so mreže vlekli k sebi.

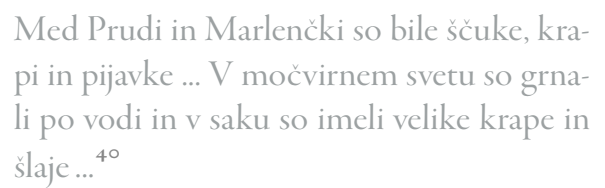

$\mathrm{Na}$ ta način so dobili po okoli 5 do 6 rib. $^{4}$ Voda je bila tu blatna in gosto poraščena, ob njej so pasli kobile, ki jim je voda tedaj segala do vampa in kadar so prišle ven, so jim morali z nog pobirati in stiskati pijavke ${ }^{42}$ (gl. tudi Rihter (2010, 3I). Studenc - tu je voda tekla, notri so bile ribe, /.../ stric je lovil ribe na Perišču ${ }^{43}$. V bližnji Borovini se je predel imenoval Žokalova amerika, kjer je bila stalna voda. Pred 80 leti so se nekateri tam kopali, drugi pa lovili ribe. ${ }^{44}$ Dolenjeskopiški pastirji so ribe lovili v kotanji Veliki šlegel ob ob Savi pri pašniku Spinca. V toplih dneh so navadno slekli del oblačila, jih na odprtih koncih zvezali s srebotino ter jih uporabljali za lovljenje in prenos rib. Ribe so čistili ob glavnem toku Save v čisti vodi, pekli pa na ognjišču iz blata. ${ }^{45}$

O življenjskem okolju šlajev na območju Studenca in Perišča v tridesetih letih preteklega stoletja piše Uršula Vodopivec:

Ta vrsta rib se zadržuje v vodi z resjem. Njih loviti na že omenjeni način zaradi resja ni mogoče. Oče si je plel takšne, imenoval jih je bobne, koše so rekli nekateri. Spravil si jih je v Vrbini, pod noč pa jih je šel nastavit. Potlačil jih je med reso, navlekel nanje tisto dolgo travo in odšel domov. Zgodaj zjutraj je že moral iti pogledat, če je kateri (šlaj, op. J. R.

39 Stanje dokumentiral avtor prispevka 3. 10. 2010, 27. 10. 2010 in 8. I I. 2012.

40 Informator RCD

4I Informator RCD

42 Informator RCD

43 Informator SZP.

44 Informator RCD

45 Informator $\mathrm{ZHK}$ 


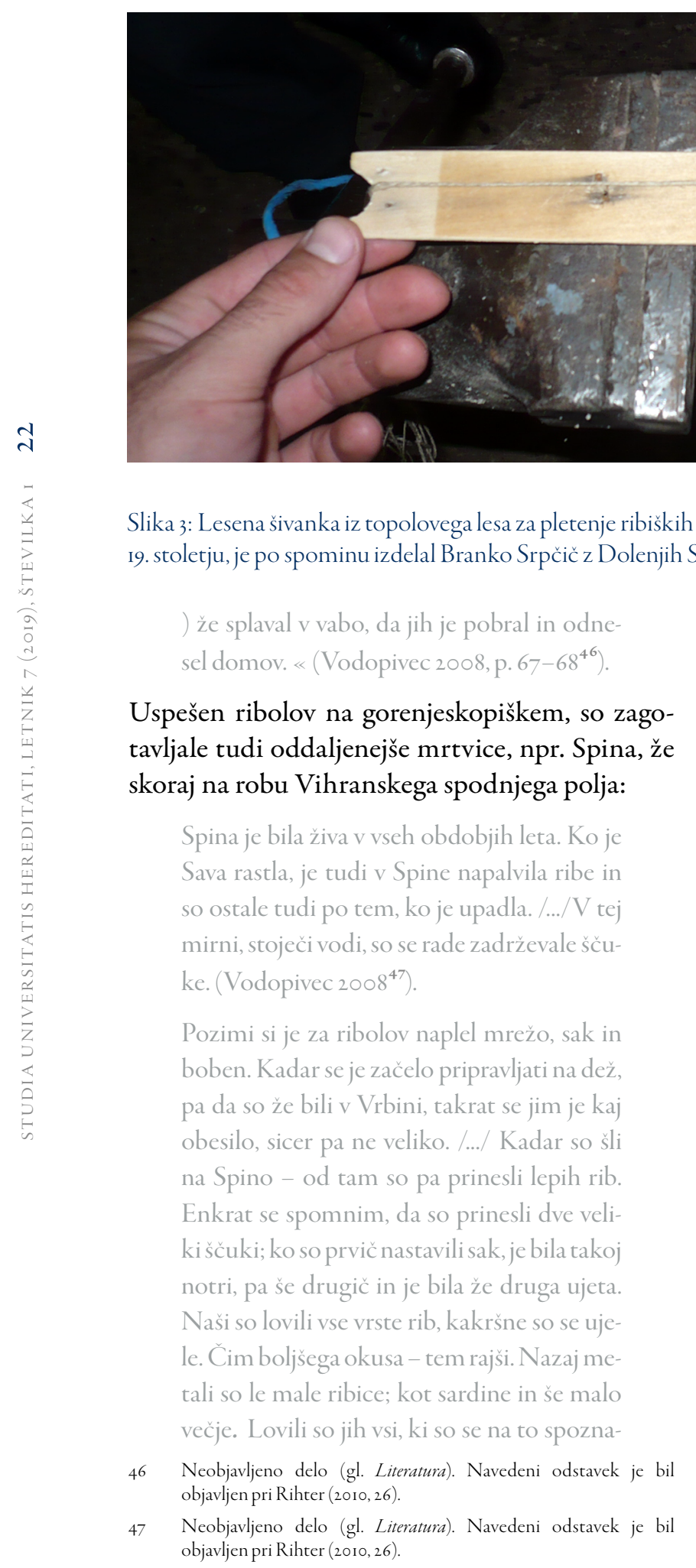

li in če so imeli s kom. (Vodopivec 2008, p. $67-69){ }^{48}$

Torbi v kateri so na skopiškem nosili ribe domov, so pravili karnir, ki je bil sešit iz domačega platna (Vodopivec 2008, p. 67-68). V bližini je bila tudi mrtvica Zlatič, ki je bila sicer znana, kot lokacija za zdravljenje s pijavkami, izpričana pa je tudi kot ribolovno območje. ${ }^{49}$

Pomudimo se še nekoliko na tem območju $\mathrm{s}$ stališča modernih opažanj in se $\mathrm{v}$ naslednjem odstavku ponovno vrnimo $\mathrm{k}$ ribolovu. $\mathrm{Na}$ njivah, ki so do danes nastale v strugi Spina, se v ornici občasno vidijo ostanki lupin rečnih školjk (Unio sp. ). Struga Spina predstavlja ostanek zadnje aktivne struge t. i. skopiškega rokava ${ }^{5 \circ}$ pred rečno regulacijo v 19. stoletju (Rihter 2009; 2015, 6I-69; 2016a, 58; 2016b, I5I). Opažanje se sklada z situacijo, ki je bila vidna leta $2016-2017 \mathrm{v}$ tej isti strugi, nekaj sto metrov severozahodneje od Spine, kjer je ob izgradni jezu za HE Brežice prišlo do uničenja Petrove škarpe ob njenem izklinu v Skopiški zaliv, v dolžini $300 \mathrm{~m}$. Pod uničeno su-

48 Neobjavljeno delo (gl. Literatura). Navedeni odstavek je bil objavljen pri Rihter (2010, 25).

Informator TXJ.

so Savski tok najjužnejšega dela skopiškega rokava je pred savsko regulacijo zajemal ledine Gorenji prudi - Spina (G. Skopice) - Zlatič - Srednji prudi - Studenec - Perišče - Dolenji prudi/Marlenčki Spinca - Veliki/Mali Šlegel. 
hozidno krono nasipa Petrove škarpe, ki je prečno zapiral vhod v skopiški rokav, so bili na globini do $3 \mathrm{~m}$ vidni tako ostanki lukenj in lesenih pilotov - ostankov regulacijskih del (prim. Rihter 2016a, 58; 2016b), kakor tudi zamuljene leče nekdanjih rečnih nivojev dna z izdatnimi količinami lupin rečnih školjk.

Nadaljujemo s pričevanji o ribolovu. Tudi druga poročila s Skopiškega potrjujejo zgoraj izpostavljene lokacije in vrste rib: Na Skopiškem se je lovilo s saki in kadar je voda rasla se je grnalo po vodi. Skopičani so večinoma lovili ob glavnem toku na ledini Pod krči ali do Cesarskega (D. in G. cesarsko), kamor je sodil tudi rečni zaliv im. Skopiški zaliv. Lovili so klece (tj. pisanica), zelenke (tj. zelenike), žagarčke (t. s. ostriži), šlaje (tj. linje) idr. ${ }^{\text {II }}$ (gl. tudi Rihter 2oro, 32). Uršula Vodopivec opisuje Skopiški zaliv, kot nekakšen zaton, ki se je običajno uporabljal za pranje pšenice. To mesto drugi opisujejo kot jamo v Savi, z imenom Perina jama. ${ }^{52}$ Kadar so na tem mestu ob spiranju žita nastavljali tudi sake, so ribe privabljali s trosenjem žita v vodo (gl. Perišča). Nadalje pravi tudi, da so nekateri ribe dvigovali iz vode s pomočjo koze. Ta pa je sestavni element ribolova z mrežo po metodi, tod imenovani na križ. O tej isti metodi ribolova govori tudi pričevanje: Mreže so pletli sami ali pa so jih od kje dobili. Lovili so v Savi šstangami in locni, pa so dvigovali.

\section{Pranje thanin in žit}

Vasi so imele po regulaciji Save različno dolgo pot do reke Save. V tridesetih letih preteklega stoletja v vaseh zahodno od Viher žehte praviloma niso več prali na Savi. V vaseh tedaj ni manjkalo vaških štirn, pa tudi privatne so bile vse bolj pogoste. ${ }^{54}$ Predvsem so na Savi še vedno spirali snetljivo žito in to opravilo je za sabo potegnilo tudi pranje rjuh. Konopljene ali lanene spalne rjuhe so imele ravno pri tem opravilu ključno vlogo oz. so bile sestavni del tega opravila. Pred

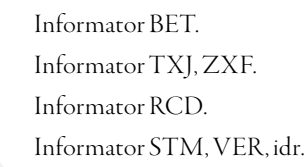

dejanskim pranjem so jih namreč najprej izkoristili še za grobo sušenje spranega žita na prodišču, nakar so bile končno oprane tudi same. Gljivam žitnih sneti, so se ob dozorevanju spore spremenijale $v$ temen prah, kar je imelo za posledico temno obarvanost oziroma zaprašenost tudi sicer zdravih žitnih zrn. Takšno žito je zavrnil vsak mlinar, zato so bili viri tekoče in čiste vode takorekoč nujni. ${ }^{55}$ Čeravno v dobi številnih vaških štirn, smo spomine, še večkrat pa prvoosebna pričevanja o tem opravilu zabeležili pri domala vsaki hiši/informatorju.

V tem oziru je na Gorenjih Skopicah veljala nekoliko drugačna situacija, saj se je v eni od vasi najbližjih starih savskih strug, preko ledine Perišče, pretakala tekoča voda - studenčnica, ki je izvirala na ledini Studenec (gl. Ribolov). To danost so zaradi razmeroma majhne razdalje od vasi (ca. $700 \mathrm{~m}$ ), napram tisti do Save, s pridom izkoriščali. Voz s tkaninami so pripeljali na Perišče, kjer so perice stale v vodi in stepale rjuhe.

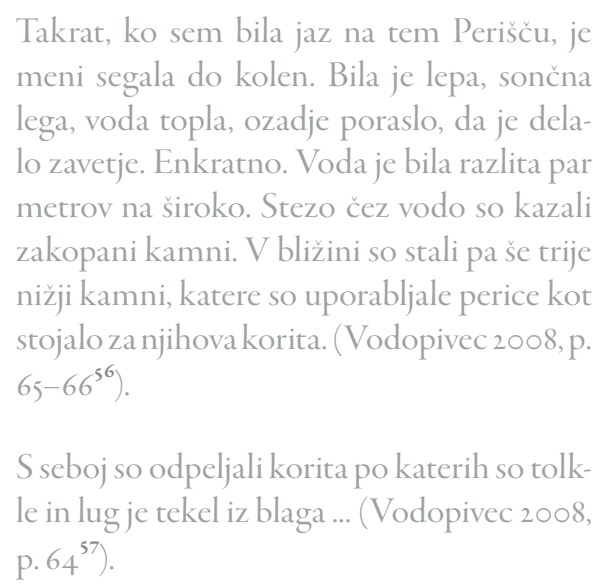

Na območju Perišča je bila voda prisotna voda še v $1960-$ tih. $^{58}$

Drugo lokacija za pranje perila na Gorenjeskopiškem se nanaša na glavni savski tok, kot stranska dejavnost ob spiranju snetljivega žita.

\footnotetext{
55 Informator VER.

56 Neobjavljeno delo (gl. Literatura). Navedeni odstavek je bil objavljen pri Rihter (2010,26).

57 Neobjavljeno delo (gl. Literatura). Navedeni odstavek je bil objavljen pri Rihter (2010,26).

58 Informator ZXF.
} 
Slednje opravilo je zahtevalo večje količine tekoče vode. V Gorenjeskopiški vrbini, na ledini Gorenje cesarsko, v bližini Skopiškega zaliva, sta bili v brežino vsekani dve dostopni rampi do vode (gl. Gradbeni...):

Oče je pripeljal voz s konicami do praga, tu
so naložili čeber z žehto. Mama je nanosila
v drug čeber še tedensko perilo, v tretjega so
pa nanosili še snetljivo pšenico, da jo je op-
rala v Savi. Ko je mama prala, sta oče in brat
obrnila seno, jaz pa sem na naši obali (bili so
lastniki travnika nad reko, op.J. R.) pazila se-
stri. Brat in oče sta navezala na travniku štrik,
da sva midva z bratom obešala rjuhe in po-
tem še ostalo perilo /.../ Midve z mamo sva
zlagali rjuhe in perilo, ter jih pospravili v čeb-
re, odvezale štrike, pospravile grablje. Moški
so pa oprali in skrtačili v vodi konja in kravi
ter jih napojili. No, oče pa je moral še pogle-
dati v sak, če se je kaj slučajno zataknilo in je
treba rešiti. Tako smo preživeli dan in se vsi
oprani in okopani vrnili domov. (Vodopivec
2008, p. 65 - $66^{59}$ ).

Nekaj deset metrov gorvodno od ravnokar opisanega mesta, so v zatonu, po Uršuli Vodopivec (ustno) imeli plavalci 6 stopnic za skakanje $\mathrm{v}$ vodo. To mesto oz. zaton, ki ga omenja, je po drugih virih prostor, ki so ga imenovali Perina jama na Savi (gl. Ribolov), drugod imenovan skopiški zaliv. V lokalni zavesti gre tu za eno najpomembnejših mest na toku Save med Krškim in Brežicami. Ta prostor je vsaj v i9. stoletju, najmočneje zaznamoval stik t. i. krškega prekopa $\mathrm{z}$ skopiškim rokavom, ki je do tlej narekoval različne zgodovinske meje (Rihter 2009; 2015, 6I-69; 2016a, 58; 2016b, I5I).

Na Mrtvicah so v i9. stoletju še prali tkanine severno od ledine Stare vačke, v strugi, ki so jo imenovali Prudi. To je bilo pred nami, kar so starši povedali. ${ }^{60}$ Brižani so prali pšenico, nekateri tudi perilo, na Sopin, na Sopini (im. tudi Sprud ali $\operatorname{Prud}^{6 r}$ ), kjer je deloval brižanski/

59 Neobjavljeno delo (gl. Literatura). Navedeni odstavek je bil objavljen pri Rihter (2010, 26).

60 Informator KHR.

6I Informatorja DIN, DIT, idr. mrtviški brod in kjer je bilo rečno dno drobnoprodnato. Tu so tudi napajali živino. Vsa ta opravila so opravljali na istem mestu, kajti drugod v brižansko-mrtviški vrbini, so bili bregovi že strmi, ker so Savo gradili savski delavci. ${ }^{62}$ Drobnoprodnato rečno dno in plitvino povsod navajajo kot temeljni pogoj za izvajanje teh del. Tudi na Vihrah so prali pšenico v Savi, tjakaj so jo peljali običajno s kobilo. ${ }^{63} \mathrm{Na}$ Drnovem, ki je najbolj oddaljena vas od regulirane Save, je bila navada pranja žehte na reki že zelo redka. Opravilo so opravljali največ 2 -krat letno, snetljivo žito pa je na Savi spiral komajda še kdo, še zlasti ne, če so imeli pri hiši že štirno. Kadar so Drnovci vendarle prali žehto na Savi, so zapregli kravo in vse peljali na plitvino pri brižansko-mrtviškem brodu, kjer so v plitvini perice ožemale rjuhe. ${ }^{64}$ Torej na isto lokacijo, kot Brižani in Mrtvičani v tem času. Ta predel je po savski regulaciji, zaobjemal še vse potrebne danosti tako za varen dostop, kakor tudi za nadalnje delo, ki je zahtevalo plitvino in ustrezno rečno dno. Ob vse bolj strmih brežinah, ki so nastajale v letih po rečni regulaciji še zlasti na zahodnem delu obravnave, je bilo takšnih mest postopoma vse manj.

\section{Lomljenje ledu in igre povezane z vodo}

$\mathrm{Tu}$ je bilo $\mathrm{v}$ zimskem času tudi priljubljeno $\mathrm{dr}$ sališče, kamor so v 1930-tih prihajali otroci raznih imenitnikov iz Krškega. ${ }^{65}$ Drsali ali sličali ${ }^{6}$ so s sliči, tj. z doma narejenimi drsalkami (Rihter 2015, I83, prim. Počkar 1998, 285), običajno iz lesenih polen okovanih s kosom železa ali žeblji, namesto vezalk pa so včasih porabili konjske cugle. ${ }^{67} \mathrm{~V}$ toplejših mesecih so tu pluli s kadujami, tj. lesenimi kadunjami za šopaje (goljenje) prašiča (Rihter 2015, I83).

Dolenjeskopiški pastirji so igrali igre na ledu na Šleglih (veliki in mali). Za lomljenje ledu pa

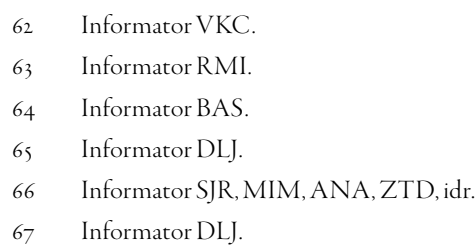


so bili skopičani angažirani v Brežicah, v Vrbini pod gradom.

Del iger je predstavljalo tudi plavanje. $\mathrm{Na}$ dolenjeskopiškem je imel Mali Šlegel plitvejšo vodo in je bil primeren za plavanje mlajših otrok, ker ni bil povezan z glavnim rečnim tokom. V Velikem šleglu je bila voda globlja. ${ }^{69}$ Plavali so tamkaj tudi na območju Pruda in Amerike. ${ }^{7}$ Brižani so se kopali v Savi na območju plitvine pri brodu. ${ }^{71} \mathrm{~V}$ vasi Brege se $\mathrm{v}$ zvezi z otroškimi igrami omenja plitva vodna površina na ledini Traminčki in Mlake pod vasjo, kamor se je v obcestni jarek ob nekdanjem jagnedovem drevoredu stekala vaška voda. Tu je prihajalo tudi do občasnega dviga talne vode. ${ }^{72}$ Drnovski pastirji so se kopali v vodi, ki je nekdaj zalivala jamo na Barovni pri ledini Za mlake.

\section{Gnoj iz mokrih kotanj ob poteh}

Med navadami manjših kmetov in sebenjkov v povezavi z mokrim svetom, je zanimivo še izročilo o »sebenkovem gnoju « z Breg, ki pravi, da so imeli sebenki iz drugih vasi, na brižanskem polju posejano po kakšno njivo koruze, ki so jo nato poželi, doma pa pokrhali štroke. Stebla - koruzenco pa so nasekljali na koščke in zvozili v kotanje na blatnih odsekih ob poti pri Barnopakah in dalje ob Gmajni. Tam so pustili, da so z vozovi vozili preko in se je zmes dodobra pregnetla z muljem. Na ta način so tudi sebenki prišli do gnoja, ki so ga nato razvozili po njivi. ${ }^{74}$ Gre za tod nekdaj razširjen princip namenske priprave kompostnega gnojiva $\mathrm{v}$ jamah - mlakah. V neposredni bližini naše obravnave, le onkraj Save, ga v župniji Videm leta I880 opisuje Dragotin F. Ripšl, ko pri opisu hišnih mlak pravi, da se v njih zbira deževnica, mulj, blato, listje, lubje, kratko rezana drozga ipd, kar vse se porabi naslednjo pomlad za gnojenje mladih trsov (Ripšl 2007,

68 Informator TXJ.

69 Informator ZXF.

70 Informator RCD.

7I Informator IFS, IKC.

72 Informator EKC, VER, IFS

73 Informator JAN.

74 Informator VER.
I46). V bližnji Veliki vasi so v 30-ih letih preteklega stoletja za potrebe gnojenja praznili mlako ob potoku v ravnini, ki je vanjo prinašal listje iz svojega zgornjega (gozdnega) toka. Še stoletje pred tem pa je bil tik ob tej mlaki, na srenjskih površinah tudi zelenjavni vrt, pri čemer njegova bližina verjetno ni naključna. Na Drnovem so z muljem iz vaških mlak (Kilarjeva in Jakševa mlaka) pri nekdanjem sejmišču bogatili le najrodovitnejše njive ledin Zevniki in Breg (Rihter 20I4, 39). Na Bregah izpričana navada izdelave gnoja ob mokrih obrobjih poplavne ravnice torej kaže, da ta proizvodnja ni bila rezervirana izključno za domače ali vaško okolje mlak, temveč se je lahko odvijalo tudi v poplavni ravnici, dlje od doma.

\section{Živinska paša in napajanje}

Živinska in konjska paša na obravnavanem območju je predstavljala najbolj razširjeno dejavnost. Zabeležili smo številna pričevanja o poteku in načinu paše ter kvalitetah in posebostih posameznih pašnikov. Paša je bila pretežno v domeni otrok in starcev. Temu prilagojene so bile ponekod tudi pašne razmere. Najmlajši otroci so pasli bližje domu, starejši dlje od doma v smeri reke Save. $S$ pašo so bile povezana tudi različne pastirske igre in znanja, kakršno je izdelovanje igrač in lesenih izdelkov za domačo uporabo ter nabiranje zdravilnih in drugih rastlin ter živali. Nekatere od teh omenjamo $\mathrm{v}$ pričujoči obravnavi. Zaradi obširnosti dejavnostih povezanih s pašo konj in živine, bodo te predmet ločene obravnave v prihodnosti. Trenutno izpostavljamo napajanje živine.

Sestavni del živinske in konjske paše je torej napajanje. To opravilo je zahtevalo večje količine primerne vode. Njeno zagotavljanje na nivoju vasi, je v času brez vododvodne napeljave, zahtevalo veliko skrb in napore, predvsem pa tvorno terminsko usklajevanje udeleženih pri skupnih vaških vodnjakih. ${ }^{75}$ Zato je bilo napajanje ob paši v poplavni ravnici nuja oz. njen sestavni del. Osnovna naloga tukajšnjih pastiric in pastirjev, je bila pašno žival v obe smeri pasti, nazaj grede,

75 Informator TTR 
ob poti, tudi napojiti. ${ }^{76} \mathrm{~V}$ obravnavanem času je bilo to še skoraj povsod možno. Vendar so bile že prisotne številne ovire, npr. neprimernost vode ali pa težka dostopnost rečne gladine reke Save na nekaterih odsekih brižansko-mrtviške vrbine, kjer se je Sava v novem kanalu do tega časa že znatno poglobila. Do izraza so zato prihajale vodne površine med reko in vasjo.

Poglejmo sedaj topografijo teh voda. $\mathrm{Na}$ skopiškem območju je bilo na gorenjeskopiškem, okoli $150 \mathrm{~m}$ dolga vodna površina na Spini (Vodopivec 2008, 77-78), na ledini Sredji prudi, se omenjajo v mrtvicah trije napajalniki ( Vodopivec 2008, p. 72, 77), to so omejena območja $z$ vodo v stari strugi. O njihovi osnovni rabi zgovorno priča ime samo. Globina najmanj enega med njimi je zahtevala plavanje živine pri prečkanju (Vodopivec 2008, p. 77) in prav tako na ledini Amerika. Na dolenjeskopiškem so bile vodne površine primerne za napajanje na več mestih vzhodno od ledine Studenec, in sicer: Dolenji prudi, Spinca/Veliki in Mali Šlegel. ${ }^{77}$ Te vode so dokončno presušile do 1960-tih let ali nekoliko kasneje. ${ }^{78} \mathrm{~V}$ vaseh zahodno od skopiškega območja so bila takšna območja površinsko manj obsežna. Na brižanskem: na ledini Globajnk (kjer se zaradi nevarnosti terena ni napajalo živine), Velike vode, Zlatičje, občasno, v jesenskem času, še na predelu Ločica in Delečki. Vodnata je bila tudi ledina Pod vrbam. Na mrtviško-vihranskem je bila voda na ledini Struga, Pod belim bregom in morda še kje v bližini Petrove škarpe. ${ }^{79} \mathrm{Na}$ Drnovem le na območju Mlak in deloma na ledini Barovna. Druge drnovske mlake, npr. Kilarjeva in Jakševa, niso bile primerne za napajanje živine.

\section{Paša gosi}

Pred drugo svetovno vojno so bile gosi, poleg kokoši tod najštevilčnejša perjad, njihova paša je bila najbolj povezana $\mathrm{z}$ mokrim svetom v neposredni bližini vasi. Na Bregah, kjer naj bi bilo,

\footnotetext{
76 Informator VER, EKC, IFS.

77 Informator RCD, STM, XSX, idr.

78 Informator ZXF.

79 Informator PAT, PAJ.
}

pred letom 194I po pričevanju, več gosk kakor rac, ${ }^{8 \circ}$ so poleg dveh s perutnino preobremenjenih vaških mlak, kjer je večja nosila značilno ime Račještališče, cenili čistejše vodne površine lučaj od vasi, na ledini Mlake in Pod vrbe, v sklopu velike ledine Gmajne. Tu je izpričana tudi paša koz, od perutnine pa so se tu v največji meri pasle gosi, ki so tod našle kvalitetnejšo pašo, kot $\mathrm{v}$ umazanih vaških mlakah. Te so številčno prevladovale nad racami, saj so jih - poleg mesa - cenili zaradi najfinejšega perja za posteljnino in peruti za omela $^{81}$ ter zaradi obrednega pripravljanja (božične) zdravilne maščobe. Nesoljena surova maščoba gosi v posodi, je bila na Bregah sestavni del jaslic in s tem božičnega blagoslova. Takšna se je stalila in se uporabljala skozi vse leto za zdravljenje. Gosjemu perju je po kvaliteti sledilo račje, ki pa je bilože težje in manj zaželjeno. Kokošje pa je zaradi svoje težine sploh veljalo za najslabše. ${ }^{82} \mathrm{Na}$ Drnovem so za posteljnino tedaj cofali perje še domala pri vsaki hiši ${ }^{{ }^{8} 3}$ dejavnost pa je pomenila tudi pomemben socialni vidik, zimskega druženja predvsem ženskega dela domačije.

$\mathrm{Na}$ Drnovem so gosi in race zahajale v obe vaški mlaki, tj. Kilarjevo in Jakšavo. $\mathrm{V}$ njih je voda človeku segala do pasu, na gladini pa je od pregretosti in preobremenjenosti $v$ vročih dneh plavala »zelena smetana«. ${ }^{84}$ Paša gosi je bila na Drnovem razširjena tudi na območju ledine Mlake v smer vasi Brege. Tam je šlo za večje in čistejše vodne površine, kot posledice dviga talne vode (Rihter 2015, I83-185). Tod zelo razširjena vrsta domačih rac so bile t. i. gluhe race ali mutke, ki so bile običajno tudi letalke. Tudi domače gosi so bile tedaj vsaj deloma še leteče. Paša teh je bila prosta, človekova prisotnost ob paši pa nepotrebna. Največ gosi je premogel vaški predel Kot, ki je bil najbližje vaškima mlakama:

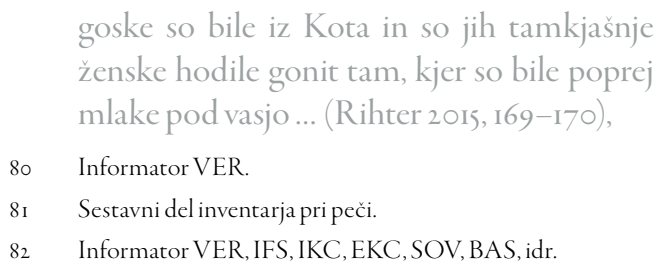


pa tudi obcestni del Fara, kjer so imeli do 25 gosi na hišo, ni zaostajal. ${ }^{85}$ Preprost izračun pove, da je občasno šlo za stotine gosk, kakor tudi sicer poriča izročilo in spomini. Gosi so na pašo hodile tudi same v gosjem sledu ali pa so iz dvorišč nad staro brežino poletavale $\mathrm{v}$ mlake in se od tam pred večerom tudi vračale. ${ }^{86}$ Opoldne so gospodinje prihajale $\mathrm{k}$ mlakam $\mathrm{z}$ žitnim zrnjem, da bi iz jate priklicale svoje gosi in jih nahranile. Pred večerom so jih prišle včasih ponovno iskat. ${ }^{87}$ Preverjali so število vrnjenih gosi in po potrebi (manjkajoče), iskali v mlakah, kjer so navadno zaostale zaradi poškodb ali nenadne obolelosti.

O dobrih pogojih za rejo perutnine v Posavju v 2. polovici 19. stoletja piše Ferdinand Ripšl, za sosednjo, videmsko župnijo onkraj Save, kjer naj bi nekatere vrste pa so ob pitanju dosegale nenavadne velikosti. Gosi so naprimer pri pečenju dajale tudi 2 dunajska funta masti (tj. I, I2 kg). Sloves videmske perutnine je tedaj segal daleč preko meja Štajerske (Ripšl 2007, I58). Reja, kokoši, rac, gosi in puranov je bila nasploh značilna za Krško polje v času konec i9. stoletja in v začetku 20. stoletja. Prav tako prekupčevanje z jajci, kjer se v Brežicah omenja »jajčni kralj« (D. S. I930, II), podobno tudi na Drnovem od koder je Vene Franc st. vozil jajca v Zagreb in v Trst (Rihter 2015, 176).

Gosi so bile še pred desetletji tod zelo pomembna vzrejna vrsta povezana $\mathrm{z}$ mokrim svetom. $\mathrm{Z}$ spremenjenimi navadami prebivalstva, modernizacijo dvorišč in novih podob vasi, opremljenih z elementi, ki so značilnejši za mesta ter $\mathrm{z}$ spremembami $\mathrm{v}$ dostopnosti do (nekdanjih) skupnih vaških površin in nenazadnje, $\mathrm{z}$ osušitvijo mokrega vaškega okolja, je reja gosi po vaseh skoraj povsem zamrla.

\section{Paša (krškopoljske pasme) prašičev}

$\mathrm{V}$ kolikor spregovorimo o paši prašičev $\mathrm{v}$ poplavni ravnici Krškega polja, pravzaprav govo-

\footnotetext{
85 Informator EDA.

86 Informator DMD

87 Informator EDA

88 Informator DMD.
}

rimo tudi o izvornem življenjskem okolju avtohtone krškopoljske pasme prašiča.

Krškopoljska pasma je predstavljala edino pasmo, ki so jo pred vojno tod redili, ${ }^{89}$ pravili pa so ji pasasta sorta, ${ }^{\circ}$ ki se ji je po vojni pridružila in pomešala še t. i. hrvaška sorta ${ }^{91}$ in druge (prim. Rohrman I899, 9; Počkar 200Ib, 577; Šalehar 2015). Zato pred obravnavo njegovega pašnega zaledja spregovorimo še nekaj o splošnih podatkih o povezavi te pasme $\mathrm{z}$ našim območjem.

Viljem Rohrman, ki prvi podrobno opisuje krškopoljskega prašiča, je izpostavil značilno območje njegovega življenjskega okolja pri Šentjerneju, ob Krki in ob Savi, na Krškem polju (I899, 9). Skupna značilnost v vaseh, ki jih našteva kot najpomembnejše pri vzreji krškopoljskega prašiča, je bližina mokrotnega obrobja Krakovskega gozda ali poplavnih ravnic Krke in Save. Drnovo poimensko izpostavlja kot pomembnejše vzrejišče, ob tem pa tudi kot enega štirih največjih središč za trgovanje s temi prašiči (Rohrman I899, 9-10). Na Drnovem so bili namreč od leta I855 dalje trije letni, veliki svinjsko-živinski in kramarski sejmi, na ledini Gmajna v stari savski strugi, in sicer: $\mathbf{1 2}$. marca , 24. junija in 29. septembra to so bili t. i. Gregorjev, Janezov in Mihelov sejem (Rihter 2015, I85-189). V I920-tih letih so krškopoljske prašiče prodajali po 8-ıo tednov stare na Notranjsko, Goriško, v Istro in v nemške avstrijske dežele, še poprej pa tudi na Gorenjsko in na Kočevsko (D. S. 1930, II). S tem se naše območje krškopoljskih vasi, s poplavno ravnico in zaledjem rodovitnih njiv, opredeljuje kot temeljni življenjski okoliš krškopoljskega prašiča, kjer je bilo hkrati zadoščeno tako gojitvenin, kakor tržnim potrebam in kjer zlasti izstopa vloga vasi Drnovo. Vas Drnovo, ima za razliko od ostalih petih v sklopu naše obravnave, ohranjene še nekatere prvine stare poljske razdelitve, ki bi je bilo - če ne iz drugačnih razlogov - nemara vsaj zaradi povezave $s$ krškopoljsko pasmo, nujno ohraniti kot tako. Poglejmo zakaj.

\footnotetext{
89 Informatorja TTR in STM.

90 Informator MIM, TTR, SJR, IFS, VER, idr.

91 Informator IFS
} 
Krškopoljčeva anatomija kratkega in močnega vratu $\mathrm{z}$ močno razvitim rilcem, pripravnim za pašo (Rohrman I899, IO), pravzaprav kaže na mokrotno okolje v katerem je živel in se razvijal. To okolje, kot smo videli v uvodu, zaradi človekovih posegov v prostor danes ni več ohranjeno. Ohranjeni pa so zadnji segmenti tedanje, stare poljske razdelitve pri Drnovem (Rihter 2015), ki izvira še iz fevdalne dobe, ki pa je prav tako sestavni del z rejo tega prašiča povezane pokrajine. Tako se je na celotnem obravnavanem prostoru spodnjega polja med Dolenjimi Skopicami in Drnovim, do dandanes z originalno poljsko razdelitvijo na delce, ohranilo komaj za vzorec polja, to je približno $1,5 \mathrm{~km}^{2}$ spodnjega polja severno pod vasjo Drnovo. Gre za edinstven preostanek mozaične pokrajine, ki v zadnjih letih posepešeno izginja $z$ intenziviranjem kmetijstva. Upamo, da bo ta ostanek starega polja v poplavni ravnici kmetijska in turistična stroka ob spodnji Savi, predvsem pa v občini Krško, če ne drugače, ob razvijanju projekta Črno-belo bogatstvo s Krškega polja, katere končni cilj je razvoj nove lokalne turistično-kulinarične ponudbe-produkta, temelječe na avtohtoni slovenski pasmi krškopoljskega prašiča (prim. Šubic 20I8), prepoznalo kot zgodovinsko izvorno zaledje reje in paše krškopoljskega prašiča ter staro delitev polja prav zato ohranilo in jo vključilo v celotno podobo t. i. »produkta « ali morda bolje, tudi v njegovo rejo. Reja krškopoljca je bila namreč tesno povezana z mozaično kulturno pokrajino in ni nikoli temeljila na intenzivnem kmetijstvu, kakršne predstavljajo in spodbujajo današnje, tod pred kratkim komasirane zemljiške površine. Drnovsko spodnje polje (trenutno, september 2019) torej še vedno, na celotnem krškem polju med Brežica$\mathrm{mi}$ in Krškim, edino še ohranja avtentično podobo iz časa fevdalne ureditve zemljišča (Rihter 2015). Čeravno je takšna parcelacija za trenutne, tod porajajoče se intenzivne oblike kmetijstva, povsem neprivlačna, bi lahko šlo na Drnovem, ob prepoznavanju naštetih dejstev, kot ključnih in pomembnih za celotno podobo te avtohtone pasme, za posebno danost in za priložnost.
Del mozaične podobe drnovskega spodnjega polja bi se moral ohraniti, kot vzorčni del stare, krškopoljske kulturne pokrajine; toliko lažje, v kolikor bi se spojila s kakšno izmed neintenzivnih in ekološko vzdržnih kmetijskih dejavnosti, kakršno npr. zahteva avtentična reja krškopoljskega prašiča. Ozadje avtentiče reje teh prašičev pa pomeni mdr. tudi neintenzivno pridelavo krme, s katero je krmljen. V praksi bi to lahko pomenilo spodbudo za oživitev kakšne izmed starih drnovskih kmetij, ki še razpolagajo z nekomasiranimi zemljišči na spodnjem polju, t. j. z okoli IO-I2 parcelami v različnih delih spodnjega polja.

Za nazornejšo ilustracijo nekdanjega življenjskega okolja krškopoljske pasme, navajamo nekdanjim našim razmeram sorodne in še danes ohranjene poplavne ravnice iz soseščine, dolvodno ob Savi na Hrvaškem, v parku Lonjsko polje. Tu še vedno izvajajo t. i. žirjenje svinj (pašo plodov) v hrastovih gozdovih, kakor tudi običajno pašo. Pašna živinoreja se tam izvaja na poplavnih travnikih, ki so hkrati tudi pomembna ribja drstišča. Velika okoljska pestrost se odraža tudi na številu živalskih vrst, ki tam domujejo. Zato ne preseneča, da je ravno tam koncentracija avtohtonih hrvaških živalskih pasem največja. Tu namreč domujejo turopoljski prašič, posavska gos, med konji - hrvaški posavec in hrvaška hladnokrvna pasma in slavonsko-sremsko podolsko govedo (Gugič 2006, 6 in II). Takšna okolja so na našem prostoru že dolgo izgubljena, nekaj možnosti za ohranitev mozaične pokrajine pa je vendarle še ostalo, kakor smo pokazali in opozorili v zgornjem odstavku ter nadaljujemo v naslednjem.

Povrnimo se sedaj v mokro okolje Drnovega in pašo prašičev. Nekdanje mokro okolje obeh vaških mlak (t. i. Kilarjeve in Jakševe mlake), v stari savski strugi v sklopu skupnega pašnika Gmajna, je bilo tipično in za celotno vas osrednje mesto paše številnih živali. Zgoraj smo že omenili tukajšnjo pašo stotin gosi, ki se jim pridružujejo tudi race, med njimi pa so bili tudi prašiči:

na gmajnah so bile svinje, ki so jih kar nagnali na pašo in koder je bila trava, so se ustavile 
in same pričele pasti. Njih paša je bila lahka, ker so bile ubogljive (Rihter 2015, I69-170).

Mirna narava in krotkost krškopoljskih prašičev je značilnost te pasme (Rohrman I899, Iо; prim. Počkar 20orb, 577). Na drnovski Gmajni se je pred drugo svetovno vojno zmeraj paslo nekaj svinj. ${ }^{92}$ Nekateri vaščani Viher so imeli možnost paše svinj v hrastovem gozdičku ob strugi pod vasjo (Rihter 2010, 30). Tam so ob in v stari savski strugi na SV delu vasi, na vaški zemlji, kjer je rasla robinja in grmovje, $v$ času pred in po drugi svetovni vojni delom še pasli prašiče. ${ }^{93}$

$\mathrm{Na}$ Bregah so se svinje pasle ob stoječi vodi na ledini Pod vrbam. ${ }^{94}$ Izpričan je tudi spomin na svinjsko pašo »pred več kot sto leti $\ll,{ }^{95}$ ki se je izvajala dlje od vasi, na območju močvirnega Globajnka in neposredne okolice, kjer naj bi se svinje tudi kalužale $\mathrm{v}$ blatu. $\mathrm{V}$ prid tej navedbi govori podatek iz leta 1893 , ki pravi, da je neki Urbanč z Breg zahteval odškodnino mdr. za 6 svinj, ki jih $\mathrm{v}$ času vojaških vaj topničarjev ni mogel pasti. ${ }^{96}$ Ker pa vemo, da je poligon za topničarske vaje na brižanskem spodnjem polju zajemal področje severno od vključno ledine Globajnk (Rihter $2016 \mathrm{~d}$ ), to pomeni, da se je brižanska prašičja paša tedaj, izvajala na pašnikih globlje od Globanjka proti reki Savi. Torej od vasi več kot $\mathrm{I} \mathrm{km}$ globoko v poplavni ravnici (Sl. I). V prvi polovici 20. stoletja pri Globajnku prašičev niso več pasli. ${ }^{97}$ Prašičja paša na skupnih gmajnah je bila v Posavju nasploh običajnejša pred I. svetovno vojno (prim. Počkar 200Ib, 579), pa tudi drugod. Omenjena poročila o prašičji paši globlje v Vrbini so torej sled starejših oblik reje prašičev, v našem primeru gotovo deloma povezane tudi z starejšo, manj osušeno podobo poplavne ravnice na območju zaledja Breg, pa tudi z spremembami v načinu kmetovanja. Na Kranjskem je prašičjereja prešla iz pašnega gospodarstva v hlevsko rejo v drugi polovici 19. stoletja. Prehod so pos-

92 Informator VVK.

93 Informator PAT.

94 Informator OFL, IFS, EKC.

95 Informator OFL

96 Dolenjske novice (15. I. 1893).

97 Informator IFS. pešile nove agrarne razmere $\mathrm{v}$ pomarčni dobi in večje izkoriščanje krmnih kultur in okopavin (krompir, koruza, pesa, detelja), ki so jih začeli na Kranjskem uvajati v skladu s fiziokratskimi prizadevanji. Povedano drugače, je prehod na hlevsko rejo, ki je bila sicer zahtevnejša, a donosnejša, zahteval privatno lastnino, potekal pa je vzporedno z razkrojem fevdalne agrarne strukture (Britovšek 1964, I45-146).

\section{Mokri svet in nadnaravno}

Človekove dejavnosti v poplavnem svetu so spremljala tudi nadnaravna doživetja, zato je prav, da jih enakovredno predstavimo. Opazna so relativno pogostejša pričevanja o nadnaravnih doživetjih $\mathrm{v}$ poplavni ravnici in na njenih robovih, kakor na zgornjem polju. Časovni seštevek tistih dejavnosti v poplavni ravnici, ki smo jih že opisali in tistih, ki jih bomo v nadaljevanju, jasno pokaže, da je človek tam preživel več časa, kot na zgornjem polju. Prisotnost človeka v zgornjem polju je bila vezana večinoma na obdelavo njiv, oskrbo posevkov in na žetev. To seveda časovno ni bil majhen zalogaj, vendar v skupnem mnogo manjši, kot tisti, preživet $v$ poplavni ravnici. Gibanje $\mathrm{v}$ poplavni ravnici $\mathrm{v}$ večernem in nočnem času, še zlasti pa v gluhi dobi noči, ki so jih občasno zahtevala različna opravila ali poti (npr. košnja, žetev), so človeka pogosto soočala z nadnaravnim. Tu se ne želimo spuščati $\mathrm{v}$ različne vidike razlag teh pojavov in povezav naprimer $\mathrm{z}$ različnimi mejami v prostoru, ki imajo $\mathrm{v}$ tradicijskih verovanjih pomembno vlogo (npr. Hrobat 2009; Mencej 2006) in so bile v tem oziru na območju Drnovega deloma že obravnavane (Rihter 2015, 206-285; 2017, 71-76). Predstavljamo zgolj kratek prostorsko umeščen pregled pričevanj o nadnaravnem, pričenši na skopiškem območju.

Nekatere dolenjeskopiške kmetije naj ne bi prale perila ali svinjskih črev na Savi, zaradi prisotnosti Babe, tj. velikanke z dolgimi nogami, dolgim krilom in rdečo ruto, ki je prala na Savi. Temu so se nekateri izognili tako, da so raje hodili prati na bližnjo reko Krko. ${ }^{98}$ Motiv velikanke, ki pere na Savi ali pa stoji z eno nogo levem

98 Informator ZHK. 
ali desnem bregu Save je tod sicer dobro znan in razširjen (Rihter 2015, 204). Vendar je običajneje povezujejo $\mathrm{z}$ dejanji, ki posegajo $\mathrm{v}$ arheološke ostanke, npr. prestavljanje rimskih kamnitih ostankov, kjer pa lahko to isto delo opravlja tudi moški lik - velikan (Rihter 2015, 204, 23I in 25I). Na območju ledine Perišče v zaledju G. Skopic, so znana pričevanja o pojavljanju lučk v nočnem času. ${ }^{99}$ Nedaleč od tu, na dolenjeskopiškem, na območju Luga, Marofa in Javšine, so gibanje v prostoru, $\mathrm{v}$ določenih smereh omejevale kače in tudi kača, ki čuva zaklad. ${ }^{100}$ Prisotnost kače, sicer s človeško glavo, je znana iz zaledja Mrtvic na ledini Struga. ${ }^{\text {IO }}$

Pričevanja o sledi božjega kosca v žitu, sicer vidne le v času žetve, so, kakor se zdi trenutno, pogostejša za spodnje polje. Šlo naj bi za več desetin metrov dolge ravne črte $\mathrm{v}$ žitu preko več njiv, ki so jih povezovali z onostranskimi, »božanskimi« znaki zadovoljstva nad dobro žitno letino. Pojav je bil omejen le na leta $z$ dobro letino. Sledi, ki jo povezujejo z božjim koscem, opisujejo na Gorenjih Skopicah, Bregah in na Drnovem (Rihter 2015, 208). Z Breg je znana v spodnjem polju na ledini Mrtvišce. ${ }^{\text {I02 }}$ Nek nepojasnjen dogodek v žitu na ledini Sarkovšče, ki je imel za posledico uničeno žito, je prav tako znan z Breg. ${ }^{\text {103 }}$ Vasi Brege prvi in najbližji skupni pašnik na območju ledine Gmajna, je bil na severovzhodnem obrobju omejen $\mathrm{z}$ vodnato in močvirno ledino Globajnk, kjer je po izročilu bival povodni mož. Njegova prisotnost je zlasti močno omejevala gibanje pastirjev. ${ }^{104} \mathrm{Ob}$ tamkajšnjem pomembnem razpotju, kjer ima $\gg$ baba noge narazen $\ll,{ }^{\text {105 }}$ na zahodnem obrobju pašnika Gmajna ob poti na Remen, je znan prostor pojavaljanja prikazni ženske s trugo (Rihter 2015, 254). Iz poplavne ravnice onkraj reke Save, je znan nočni kosec prikazen, ki kosi na drugem koncu travnika na-

99 Informator BET.

Ioo Informator ZHK

IOI Informator XMR.

IO2 Informator EKC, VER

IO3 Informator KHR.

I04 Informator VER, EKC, IFS

Ios Informator DIN. S tem izrazom opisuje križiščce Y-oblike. sproti dejanskemu koscu - pričevalcu (Rihter 2015, 268).

Pomembna prostorska točka je širše območje podružnične cerkve sv. Urha na Vihrah, ki stoji ob cesti, ki tam prehaja iz zgornjega polja $\mathrm{v}$ poplavno ravnico. Tamkajšnja nadnaravna srečanja zajemajo širok spekter izročil, ki se pojavljajo med ledino Pri križi in cerkvijo. Med njimi je zlasti zanimiva prikazen nevarne divje svinje z I2 mladiči ter izročila o prestavljanju cerkve, utopljenem dečku v jezeru, naplavljenih cerkvenih vratih, o lesenem gradu in drugih nenavadnih doživetjih (Rihter 2015, 240), pridružujejo pa se jim še $z$ arheološkimi ostanki povezana izročila o rimskih vratih (Rihter 2017,64 ). Približevanje cerkvi je bilo pri nekaterih skopiških hišah dovoljeno le v času maše na dan sv. Urha, ki je mdr. naznanil tudi pričetek izkopavanja mladega krompirja za hrano. Nasploh je bila tudi sama cerkev nosilka nadnaravnih pojavov, saj naj bi mimoidoči bili vedno znova vznemirjeni nad prižiganjem luči in občasno (ne)zastrtimi okni. ${ }^{106}$ Vihranska ledina Brodišče pod Brežnicami, ki predstavlja večperiodno arheološko najdišče (Pergar in Rihter 2008, 297), kjer naj bi v času turkov deloval brod (Rihter 2010, 32-33; 2015, 278; 2016, 242) in ledina Zgorelo v poplavni ravnici, sta $\mathrm{v}$ izročilu povezani s čarovnicami, kot lučkami. ${ }^{\text {x }}$

Z Drnovskega območja so znana številna pričevanja o nadnaravnih doživetjih, zlasti z območij, ki mejijo na poplavno ravnico ali pa so $\mathrm{v}$ starih strugah. Npr. o divji jagi v strugi na relaciji Drage-Gauge-Žadovinek, o velikem človeku - nemem spremlejvalcu na cesti ob strugi med drnovskim Belim bregom in Zevniki, ali mrtvecu, ki preko Drašč sledi koscem na ledino Remen, idr. (Rihter 2015, 254-260, 267). Izstopajoč prostor $s$ posebno nadnaravno veljavo na tem območju izstopa ledina Gauge pri brižanskem Belem bregu (Rihter 2008), severno od Drnovega, ki zajema staro savsko brežino, na križišču in stiku katastrskih mej. Tamkajšnjim različnim pojavom, od nočnih lučk, izročil o obešanju ljudi,

I06 Informator ZHK.

107 Informator PAT, CAR 
o zbirališču čarovnic, o nasilnih čarovnicah, ki lovijo mimoidoče, do strašljivih zvokov, idr., se pridružujejo pričevanja o nenavadnih doživetjih tudi $\mathrm{z}$ ledin $\mathrm{v}$ neposredni bližini (Rihter 2015, 257-258, 262). Ledina Mlake, v stari strugi pod vasema Drnovo in Brege je bila splošno znana po nočnih lučkah, sam prostor na območju arheoloških ostalin Nevioduna, pa tudi kot zbirališče čarovnic (Rihter 2006; 2015, 244-245).

Številna pričevanja o nadnaravnih elementih $\mathrm{v}$ poplavni ravnici, torej logično odražajo intenzivnost človekove prisotnosti v njem, predvsem pa jo $\mathrm{v}$ percepciji prostora postavljajo enakovredno med sestavne dele vaških celot. Poplavna ravnica se torej tudi preko nadnaravnega ponovno kaže kot neločljiv in sestavni del vsake vasi.

\section{Nabiralništvo}

Sledijo opisi navad vsakovrstnega nabiranja rastlin in živali v poplavni ravnici, s kratkim dodatkom o lovu. Pri tem imejmo v mislih, da so bile ob tem na zgornjem polju le njive in zelo redki travniki, še manj pa je bilo pašnih površin. $\mathrm{Z}$ grmičjem poraslih površin skorajda ni bilo. Zato je bilo večina nabiralnišstva skoraj izključno vezana na poplavno ravnico. $V$ nadaljevanju obravnave je delitev na hrano za živali in za ljudi vzpostavljena arbitrarno, za potrebe lažjega pregleda in drži le v grobem. Vemo namreč, da sta se obe skupini po namenu pogosto prepletali, najpogosteje vobdobjih pomanjkanja.

\section{Hrana za živali}

Podroben vpogled $\mathrm{v}$ nabiralništvo $\mathrm{v}$ poplavni ravnici pred letom 194I, nudijo pričevanja tedanjih sebenjkov, pa tudi kmetov, v zvezi z dopolnjevanjem prašičje krme. Tudi tu, kakor pri paši je ključno vlogo nosilo prav spodnje polje. Za robovi strug in ob mejnicah srenjskih pašnikov ter ob poteh, je bilo moč s prosto rastočimi rastlinami znatno dopolnili primanjkljaje krme, kar je prišlo do izraza še posebej spomladi, v času po setvi in pred žetvijo, ko je bilo pomanjkanje največje. Strah pred izgubo te možnosti ilustrira te- danje ljudsko razmišljanje, ki je postalo sedaj, ob komasaciji zemljišč ponekod zopet aktualno:

\section{Pravili so že tedaj, da ko bodo veliki kmetje strnili svoje njive skupaj, majhnim ne bo os- talo niti za kozo napasti ob poti. ${ }^{\text {1.8 }}$}

Na Drnovem so pri neki dninarski hiši v I930-tih za svinjski kotel ${ }^{109}$ pleli po stari savski strugi ob njivah in mejah proti severu, vse do ledine Gauge. Nabirali so mladi osc (osat) in modrušo, ki naj bi cvetela $\gg$ rdeče in zeleno $\ll{ }^{\mathrm{IIO}} \mathrm{oz}$. modro, med žitom ${ }^{\text {III }}$ ter mlečk, ki so mu pravili tudi frauca, kakor so imenovali spodnji del maka (Papaver sp. ) v času pred razvitejm cveta. Na boljši zemlji, v svižnatem ${ }^{112}$ na pašniku Barovna so nabirali še lapuhovo listje (Tussilago farfara), ki so ga svinjam kuhali skupaj s koprivami (Urtica sp. ), bezgovim listjem (Sambucus sp. ) in slakom (Convolvulus arvensis) skupaj z žiti. ${ }^{113}$ Pri neki drugi kmetiji na Drnovem so dopolnili kotel v kobinaciji kopriv, osata, fravce in slaka (Convolvulus arvensis), ${ }^{\mathrm{Ir} 4}$ ponekod so v kotlu nad žito (ječmen in koruzo) dajali le lapuh. ${ }^{\text {II5 }}$ Lapuh je bil običajno sestavina kuhanih obrokov, surovega niso pokladali. ${ }^{116} \mathrm{Na}$ Barovni so za kotel nabirali še velike liste parkla (verjetno Heracleum sphondylium), ki so ga skupaj s koprivami in bezgovimi listi kuhali nad ječmenom $v$ pečeh. ${ }^{\text {II7 }}$

Io8 Informator SOV.

I09 Z izrazom svinjski kotel označujem - kakor danes informatorji svinjsko skuho, čeravno se je ta v času, ki ga obravnavamo, izvajala še skoraj izključno v krušnih pečeh v svinjskih loncih iz lončenine in ne v kotlih. Informatorji že zelo dolgo v te namene uporabljajo brzoparilnike, ki mu pravijo kotel. Sprva so ponekod imeli njegovo predhodno različico, tj. obzidano litoželezno posodo - kotel. S to napravo je povezan že tudi nov prostor, to je t. i. svinjska kubna, ki je bil tod, pred 2. svetovno vojno, kot zidan in samostojen prostor, še izjemno redka zgradba. Ena prvih je bila na Škrabčevi domačiji na Bregah že v 1930-tih letih., kjer je bil v istem času zgrajen tudi eden prvih objektov z armirano litobetonsko stropno ploščo.

I IO Informator TTR

i i Informator EKC.

II2 Rečne naplavine najdrobnejšega peska tod imenujejo sviž.

I13 Informator TTR.

I1 4 Informator ALS.

i15 Informator VMA.

I16 Informator IFS.

I17 Informator EDA. 
Slak so tod, med pleveli, poleg kopriv, prištevali $\mathrm{k}$ izdatnejšim krmilom. $\mathrm{Na}$ Bregah so kmalu po skopnenju snega za prašiče nabirali ostk (osat) in frauco, kasneje tudi sunogo, ki je rasla po nezoranih njivah. Našteto so pokladali prašičem večinoma surovo. Enako tudi vodiko ${ }^{\mathrm{II} 8}$ ali vodenko, ${ }^{\mathrm{II} 9}$ ki so jo želi po Vrtih in ob močvirnih predelih. ${ }^{\text {I20 }}$ Špela Pungaršek (Prirodoslovni muzej Slovenije) je vodenko, ki jo je v naravi poiskala Vera Jurečič z Breg, identificirala kot navadno krišino (Parietaria officinalis). Sunogo, ki jo je v naravi poiskala Elka Grilc, pa kot smrdljičko (Geranium robertianum) (Pungaršek, Š., osebna komunikacija, Io. 5.2016 in I. 7. 2016). Tudi regač (navadni svinjak, Hypochaeris radicata), ki se je na Bregah trebil iz travnikov in z njiv kot plevel, so dajali svinjam skupaj z navadnim regratom kar surovega. ${ }^{\mathrm{I2I}} \mathrm{Za}$ svinjsko skuho so na Bregah nabirali koprive in slak ter ostk (osat). ${ }^{122} \mathrm{Ob}$ omembah osata dodajamo še, da so ga povsod tod uporabljali tudi za prvo pomoč pri urezninah (poleg lastnega urina) in drugih poškodbah na polju. Osat so zmehčali v dlani, da se je pocedil sok, ki so ga nanesli na rano. ${ }^{123} \mathrm{Ob}$ lapuhu kot krmi, je znana tudi njegova razširjena uporaba pri toaleti za veliko potrebo. ${ }^{124}$

Ivanka Počkar je pri obravnavi različnih vidikov domače svinjereje v Posavju, med hranili zabeležila tudi koprive in lapuh (200Ib, 578 ), v podobnih kontekstih krmljenja s kuho, kot smo jih zabeležili v naši raziskavi.

\section{Hrana (rastlinska) za ljudi}

Bezgovo cvetje in cevtje hacane ali gacje (tj. robinje; Robinia pseudoacacia), ki so ga nabirali ob poraslih brežinah, so tod povsod cvrli v tajgu (tj. jajčnem testu) za posladek. Omenimo še, da so donedavno njeno listje skupaj z vejami sekali

I18 Informator IFS

I I9 Informator VER, EKC.

I20 Informator IFS.

I2 I Informator VER.

I22 Informator VER

I23 Informator VER, EKC, TTR, idr.

I24 Informator MIM, VER, ANA, idr. tudi za krmo kuncem v prosti reji v hlevu, ${ }^{\mathrm{I} 25} \mathrm{ki}$ so jih tod redili pred drugo svetovno vojno. ${ }^{126}$ Pomladno nabiranje regrata (Taraxacum Weber sp. ) in motovilca (Varianella Mill. sp. ) po strniščih in drugod je bilo splošno prisotno še nedavno. Motovilec v času prve polovice 20. stoletja ni bil (skoraj) nikjer vrtni posevek, temveč samorasli strniščni pridelek, nabiral pa se je, kakor regrat, tudi za prodajo na trgu v Krškem. Najboljši regrat in najlažje dostopen (rahla zemlja) je izviral iz polja v poplavni ravnici. Pri regratu za živalsko hrano je ponekod šlo za temnozelene, bohotne nadzemne dele regrata, ki uspevajo ob poteh in na travnikih. Teh večinoma niso uporabljali za ljudsko prehrano, kot je to $v$ navadi dandanes. Še nekako do začetka 9o-ih let 2o. stoletja je bil tod bolj cenjen beli, podzemni del regrata, ki se je spomladi kopal ob robovih jeseni preoranih strnišč njiv ali travnikov ter deteljišč ali pa v krtinah. Regrat je spomladi pognal iz globine preko ornice na površje, pri tem pa ustvaril dolg bel podzemni del, ki je spominjal na radič. Mešane solate $\mathrm{z}$ regratom so tedaj $\mathrm{v}$ zgodnjepomladanskem času marsikje večkrat predstavljale glavno oz. samostojno jed celotne družine. V povojnem času so globoko koreninjen regrat $\mathrm{v}$ razmeroma mehki ornici običajno ruvali z vojaškimi bajoneti, ki so tod ostali še iz časov nemške okupacije. V 90-ih letih preteklega stoletja je regrat, kakor tudi motovilec, z njiv postopoma izginil skupaj z drugimi vrstami plevi, najverjetneje kot posledica uporabe herbicidov.

Nabiranje travniških kukmakov - šampinjonov na travnikih in strniščih žit v spodnjem polju ni mogoče, saj uspevajo izključno na zgornjem polju (pleistocenska terasa). $\mathrm{V}$ poplavni ravnici pa so nabirali predvsem štorovke na deblih topola. V okviru domačih vrtov pa največ na slivovih štorih. ${ }^{127} \mathrm{Na}$ Vihrah so jih nabirali pri belih topolih na ledini Podjagendi. ${ }^{128} \mathrm{~V}$ G. Skopicah so spomladi v manjši meri uživali še listje gabeza (Symphytum sp.), ki so ga pome-

I25 Informator TTR

I26 Informator VER

I27 Informator SIR.

I28 Informator MRI 
šali v jajčno cvrtje, $v$ poznem poletju pa na isti način tudi ob reki nabran divje rastoči hmelj (Humulus sp. ) in še nekatere druge mlade poganjke rastlin, ${ }^{129}$ med njimi npr. kopino tudi $\mathrm{v}$ čaju. ${ }^{{ }^{30}}$ Podobno, v jajčnem cvrtju, na Bregah, le v zdravilne namene tudi poljac (Mentha pulegium) (gl. Zdravilne ...).

Še zlasti pastirji so dobro poznali oz. vedeli za rastišča plodonosnih grmovnic. $\mathrm{Ob}$ poti v Vrbino so na G. Skopicah obirali maline in drugo plodonosno grmičevje (Vodopivec 2008, p. 7I-72). Sicer pa so se skopiški otroci v Vrbini sladkali še $\mathrm{z} \gg$ vlašicami ${ }^{1331}$ kakor so imenovali neko vrsto jagodičevja (Rihter 2010, 30), pa tudi z medvedovimi hruškami (glog; Crataegus sp. ), trnulami (črn trn), ipd. ${ }^{\mathrm{I32}} \mathrm{Na}$ drnovskem območju so za prehrano nabirali tudi plodove črne in bele murve (Morus sp. ) ter divjih češenj, ki so tod še dandanes razširjena drevesa. Murve so po izročilu ostanek sviloprejske dejavnosti povezane $\mathrm{z}$ velikovaško graščino (Rihter 2014, 79). Na Drnovem tarnul (črni trn) omenjajo za kuho marmelade (Rihter 20ı, 33). Tudi iz gloga so ponekod kuhali marmelado, ${ }^{133}$ iz češmina pa napravljali kis. ${ }^{134}$ Pastirji z Breg so žvečili in (ali) jedli: češmin ${ }^{135}$ (Berberis vulgaris), trnule (črni trn; Prunus spinosa), ${ }^{136}$ medvedove hruške, lešnike (Corylus avellana), divje jagode (Fragaria sp. ) kopine (robida; Rubus sp. ), kislico (Rumex acetosa), gartrože (šipek; Rosa sp. ), črna semena dobroletine (Viburnum lantana) in srkali cvetni med kozjega zizka (kovačnik; Lonicera caprifolium). ${ }^{137}$ Preseneča redkost drena tedaj, kakor še danes:

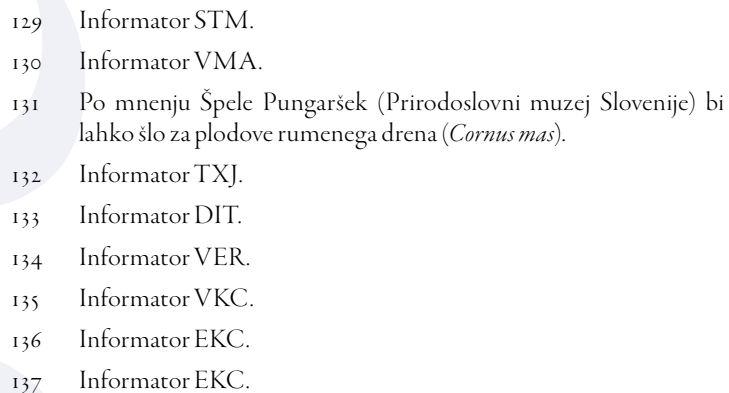

\section{$\mathrm{Na}$ brižanskem je bil samo en dren proti le- skovški gmajni, kjer je še danes, uporabljali paso ga za izdelavo butaric. ${ }^{138}$}

Izpričana je uporaba njegovega lesa, o uporabi njegovih plodov ne govori skoraj nihče. Za Brege se omenja, da so v Vrbini nabirali plodove neke vrste grmovnice za črnilo in liste za zdravljenje rdečike pri prašičih (Rihter 2010, 30), vendar nam v kasnejših pogovorih, teh rastlin ni uspelo identificirati. Ena od možnosti uporabe za črnilo je izpričana v okolici Trebnjega, kjer so za izdelavo črnila uporabljali črni trn (Papež 20IO, 38 ).

Danes izginula cipresovka $\mathrm{v}$ Vrbini je brin (Juniperus sp. ). Na vihranskem je bilo veliko brinja na pašnikih im. Cesarsko. Nekateri so brinove jagode nabirali in jih dajali $\mathrm{v}$ šnopc, večina pa ga je uporabljala pri dimljenju mesa. ${ }^{\mathrm{I} 9} \mathrm{~V}$ Gorenjeskopiški vrbini:

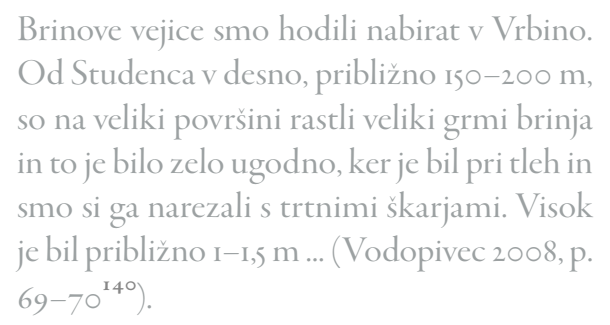

V Brižanski Vrbini je rasel na ledinama Mali in Veliki prudi (Rihter 20ı0, 30). Tako v skopiškem kot v brižanskem primeru je bilo njegovo rastišče v prvi polovici 20. stoletja tam, kjer so bili v 2. četrtini 19. stoletja ali še kasneje, rečne struge še pretočne, a so po savski regulaciji ostale suhe in puste. Kakor ugotavljajo domačini, je brin že v začetku 2. polovice 20. stoletja povsod tod postopoma izginil. Od začimb se na Bregah omenjajo rastišča kimla (kumine) na ledini Stare gmajne. ${ }^{141}$ V zvezi s tem je tod znano, da se kumina pojavlja na ilovnatih tleh, navadno na robovih Krškega polja, npr. ob vznožju Veniš, zato je pričevanje v primeru Starih gmajn zelo pomenljivo. Tam je šlo ob meji z Hančavimi Lastina-

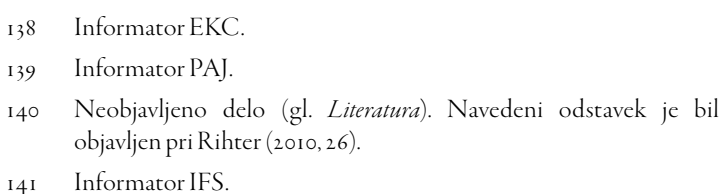


mi za strugo z ilovnato naplavino, $v$ situaciji podobno, kakor je predstavljeno v poglavju Ilovica (gl. tam).

V raziskavi prehrane v 19. stoletju na Slovenskem, Gorazda Makaroviča, najdemo številne vzporednice z zgornjimi podatki in tudi prepletanje istih rastlinskih vrst tako $\mathrm{v}$ ljudski prehrani kakor tudi pri živalski krmi (prim. Makarovič 1991, I6I-163). Prav tako sta tozadevno izpovedni raziskavi Borisa Kuharja iz srede 20. stoletja z območja Škocjana na Dolenjskem (Kuhar 1972) in Vilka Novaka (1947) za območje Prekmurja. Slednji je izpostavil tudi pomen zbiralnega/nabiralnega gospodarstva tako z etnološkega (Novak 1957, 19-20) kot tudi gospodarskega vidika in nekatera $s$ tem povezana raziskovalna vprašanja (Novak 1957, 27). Vlasta Mlakar prinaša pregled tradicionalnih znanj o uporabi rastlin na Slovenskem (2015), kjer najdemo našim podobne ter številne druge primere uporabe rastlin.

\section{Zdravilne rastline}

Brižani so kot zdravilno rastlino cenili polaj ali polajc (iz nem. polei za Mentha pulegium), ki je rasla na gmajni Pod vrbami, nekoliko višje nad tam zastajajočo vodo, za razliko od sička (gl. Druge ...), ki je tam rasel neposredno ob vodi. Polajc je dišal kot meta in ji je bil tudi podoben, cvetel pa je modro. ${ }^{142} \mathrm{Na}$ Drnovem so ga imenovali polaj in so ga nabirali na območju Gmajne na predelih v stari strugi. ${ }^{\text {I43 }} \mathrm{Na}$ Bregah: Jedli smo / ... /, če si bil bolan pa polajc z jajci. ${ }^{144} \mathrm{Ra}$ stlino so osmukali in pekli z jajci, zato so pravili tudi: Polajc pa devet jajc! Ali pa: En poljac pa deset jajc! ${ }^{145}$ Nekateri razlagajo pretirano količino jajc s tem, da se je šele tako lahko pojedlo sicer zelo grenak polajc, ki so ga uporabljali tudi proti driski. ${ }^{146}$ Drugi pravijo, da je pomagal pri prehladu in za pljučne bolezni. ${ }^{147}$ Zvočno podob-

I42 Informator VER.
I43 Informator EDA.
I44 Informator EKC.
I45 Informatorji VKC, VER, EKC in IFS. Obstaja več variant o številu
jajc.
I46 Informator IFS.
I47 Informator EKC.

no ime za neko zelišče imenovano pelajc se pojavlja nedaleč od tod, v Gorjancih, in sicer v vaseh okoli Orehovca, kjer so poznali »čaj za moške iz »moškona«, »pelajca «, ki naj bi pomagal tudi pri prehladu. «(Sosič 2000, 243).

A že v sosednjih Mrtvicah so nekateri imeli istoimensko, vendar očitno ne enako rastlino, polajc, za t. i. grdo rastlino, ki naj bi povzročala glavobol. Nekateri so jo uporabljali kot repelent, za žvadi tikute ${ }^{\mathrm{r} 48}$ odganjati. Na Mrtvicah ga je bilo največ na Gmajni, a se je do danes zatrl. ${ }^{\text {I9 }}$ $\mathrm{Na}$ Mrtvicah verjetno ni šlo za isto rastlino kot na Bregah, čeprav ju po ljudskem spominu druži isto ime. Izginotje te rastline v brižanski vrbini domačini povezujejo s savsko regulacijo in posledičnim padcem talne vode.

$\mathrm{Na}$ brižanskem spodnjem polju so poznali na pustih tleh rumeno deteljico, ki so jo nabirali za zdravilni čaj, ${ }^{\text {I5o }}$ cvetela je med prvimi cvetlicami že konec aprila na ledini Pliš-Zaroman ${ }^{\text {I5I }}$ in na ledini Remen. ${ }^{152}$ Po vojni so jo nabirali in sušili za farmacijo. ${ }^{153}$ Rasla je tudi na ledini Flančišče in povsod na ubožanih travnikih. ${ }^{154}$ Poznali so tudi belo deteljico, ki je imela »bel, resast cvet $\ll$ za katero so pravili, da je za »en čaj ${ }^{15}$. 5 Špela Pungaršek (Prirodoslovni muzej Slovenije), domneva, da bi lahko šlo v prvem primeru najverjetneje za hmeljno meteljko - Medicago lupulina ali pa za poljsko deteljo - Trifolium campestre), $\mathrm{v}$ drugem pa najverjetneje za plazečo deteljo - Trifolium repens (Pungaršek, Š., osebna komunikacija 6. 5. 2016).

Tavžentrože (Centaurium Hill sp. ) so na brižanskem rasle na slabi zemlji severno od Zarbenic in do reke Save. ${ }^{156}$ Prav tako na Zaromanih tam, kjer so bila tla pusta. Bile so priljubljeno

\footnotetext{
I48 Informator KHR. Tikut v pomenu tekut in źvand ali źvad, ki na Krškem polju pomeni domačo perjad, še zlasti kokoši. Npr. žvausko meso, v pomenu kurje meso.

I49 Informator KHR.

I50 Informator VER. Informator ne pomni v kakšne namene.

I5 I Informator IFS

I52 Informator EKC

153 Informatorja IFS in VKC.

I54 Informator VER. Ubožani travniki so slaborodni travniki.

I55 Informator VER

I56 Informator EKC
} 
zdravilo moških za želodčne težave. ${ }^{157}$ Vihrani so nabirali tavžentrožo na ledini Cesarsko in na ledini Toplica. ${ }^{158} \mathrm{Na}$ skopiškem so rastle po pašnikih, kjer so ostajale za kravami, ki so jih zaradi grenkobe puščale. ${ }^{159} \mathrm{Na}$ Drnovem so hodili po tavžentrožo (Centaurium sp. ) na Barovno, ${ }^{160}$ drugi pa na t. i. Vrbinske travnike, t. j. v Remen in Zaroman. ${ }^{61}$ Namakali so jo v žganju, uporabljali pa za obkladke in masiranje, sušili za čaj ali pa jo nosili prišito v rob površnika, da jih je varovala pred uroki. Če je bilo tavžentrože kako leto malo, so nabirali tudi rumeno cvetočo grenčico (Blackstonia perfoliata), ki je bila zastopana $\mathrm{z}$ dvema podvrstama, obe sta uspevali na drnovskih travnikih stare savske struge. Njuna grenčina, je pomagala pri umirjanju razdraženega želodca (Sonja Budna, osebna komunikacija 23. I1. 2016). Že leta I85 I je Valentin Plemel grenčico, tedaj imenovano Chlora perfoliata (Sonja Budna, osebna komunikacija 23. II. 2016), nabiral na mokrih travnikih v stari savski strugi pod Drnovim - kakor je izpostavil - le lučaj proč od rimskodobnih ruševin (Plemel I862, I28), ${ }^{162}$ najverjetneje na ledini Mala barovna.

$\mathrm{Na}$ dolenjeskopiškem, na ledini Marof je rasla arnika (Arnica montana). ${ }^{163}$ Iz šentjanževke (Hypericum perforatum) so na Bregah napravljali šentjanževo olje, ki so ga dali na sonce, da je rdeče ratalo. ${ }^{164}$ Šentjanževka je rasla na koncih njiv, kjer je bila stara savska brežina, npr. na ledini Stari tramleki. Tam, skonca je bilo vsesorte rož. ${ }^{165}$

$\mathrm{Na}$ Drnovem so nabirali materino dušico na drnovskih Flančiščih ob robu ledine Barovna. Pri nekaterih hišah so jo, poleg siceršnje rabe za zdravljenje prehladov, s posebno recepturo uporabljali tudi za umiritev driske. ${ }^{166}$ Glog so nabi-

$\begin{array}{ll}157 & \text { Informator VER. } \\ 158 & \text { Informator CAR. } \\ 159 & \text { Informator RCD. } \\ 160 & \text { Informator BAS. } \\ 161 & \text { To pomeni na območje vasi Brege, na predel Remen in Zaroman. } \\ 162 & \text { Za ta podatek sem hvaležen Sonji Budna. } \\ 163 & \text { Informator SUT. } \\ 164 & \text { Informator VER. } \\ 165 & \text { Informator VER. } \\ 166 & \text { Informator TTR. }\end{array}$

rali v času cveta za probleme s pritiskom. ${ }^{167} \mathrm{Za}$ domače zdravljenje so Drnovci v Vrbini nabirali »češmigono « (češmin) in »babji zob (šipek) ter lipove cvetove (Tilia sp. ) (Rihter 2010, 30). Pri neki hiši na Drnovem so po obnovi med vojno požgane domačije pastirjem naročili, naj jim prineso iz Vrbine mlado lipo, da bo hiši v okras, za senco in za čaj. ${ }^{168} \mathrm{Ob}$ poteh, na suhem je rasel rmanc (rman; (Achillea sp. ), ki so ga uporabljali za čaj in za zdravljenje razpokanih nog ${ }^{169}$ ter kot nujno sestavino piče za mlade račke. ${ }^{170} \mathrm{Na}$ pašniku Barovna so nabirali tudi gladeš (Ononis sp. ) in ga uporabljali za odvajanje vode iz telesa ${ }^{171}$ in za lajšanje težav z ledvičnimi kamni. ${ }^{172}$ Brižani so ga na Gmajnah kosili skupaj z ostalim travinjem za steljo, ker ga živina ni marala (gl. Stelja). ${ }^{173}$ Vihrani pa so njegove korenine uporabljali za zdravljenje konj in ledvičnih kamnov, nabirali pa so ga na ledini Cesarsko. ${ }^{174}$

$\mathrm{Na}$ Mrtvicah so v Vrbini, ob poteh, na pustih tleh nabirali vratič (Tanacetum vulgare). Uporabljali so ga za zdravljenje živine, kadar jo je napihovalo. Nabirali so ga na ledini Prudi severno od Starih vačk. ${ }^{175}$ Vratič so na D. Skopicah sušili in kobilam dajali med oves, za boljše odvajanje blata in za siceršnje zdravje. ${ }^{176}$ Iz Drnovega je znan podatek o nekdanji uporabi vratiča za mehansko razširjanje materničnega vratu za sprožitev prekinitve nosečnosti (Sonja Budna, osebna komunikacija, 26. II. 20I6). Na Bregah so vratič uporabljali za teleta, če so imela drisko. Iz cvetov so kuhali čaj. Nekateri ga imajo tu sedaj za okras v vrtu, nekdaj pa so bila njegova rastišča ob brežinah, kjer niso kosili ter ob grmovju in ob po-

$\begin{array}{ll}\text { I67 } & \text { Informator EDA. } \\ \text { 168 } & \text { Informator TTR. } \\ 169 & \text { Informator TTR. } \\ \text { I70 } & \text { Informatorja MIM in VER. } \\ \text { I7I } & \text { Informator VVK. } \\ \text { I72 } & \text { Informator PLO. } \\ \text { I73 } & \text { Informator VKC. } \\ \text { I74 } & \text { Informator PAT. } \\ \text { I75 } & \text { Informator KHR. } \\ \text { I76 } & \text { Informator RCD. }\end{array}$


teh. ${ }^{177} \mathrm{Na}$ Vihrah so ga uporabljali proti driski za prašiče in za živino. ${ }^{178}$

Kot mažo so na Mrtvicah pripravljali gabezove korenine, ki so jih prepražili na maščobi. ${ }^{179}$ $\mathrm{Na}$ Drnovem so gabezovo mast (iz gabezovih korenin) uporabljali za težko celeče se rane, ozebline in preležanine (Sonja Budna, osebna komunikacija, 26. II. 2016).

Za bolezni srca so Mrtvičani nabirali glog in trnulo ali trnuluc (črni trn), ki je rasel na (mrtviški) Barovni, Drašcah in na Prudih. ${ }^{180}$ Glog so uporabljali za zdravljenje težav povezanih s srcem, kuhali pa so ga v čaju. Nabirali so tudi šipek, ki so mu tam pravili divja gajtroža. ${ }^{181}$ Iz čičmigone (češmin) so po vojni delali tudi kis. Gladeš so kopali za zdravila na ledinah Stara vačka in Prud. ${ }^{182} \mathrm{Na}$ Bregah je na predelu Gmajna rasel na več mestih (gl. Stelja). ${ }^{183} \mathrm{Za}$ drisko so na Mrtvicah nabrali hrastovo lubje. ${ }^{184}$ Podobno so tudi na Vihrah zdravili drisko svinj s hrastovim lubjem. ${ }^{185}$ Sladke koreninice so na Vihrah rasle na ledini Pod belim bregom. ${ }^{186} \mathrm{Na}$ brižanskih pašnikih je rastel tudi bodeč kačji stric, kot pravijo, dveh vrst, in sicer visok, ki je cvetel rdeče ter nizki z belim cvetom, ki je kazal vreme.

\section{Rastlinje za okras}

$\mathrm{V}$ veselje in za okras so predvsem pastirice v 1930tih letih na brižanskem, nabirale različne rože, predvsem je izpričano veselje do nabiranja orhidej, ki jih opisujejo takole: V Zaromanih na Pliši so rasle kukavice/kukuce, imenovali so jih tudi petelinčki (Ophrys sp. ). Najprej so nabirali modrellila (Orchis morio), za tem pa še mačja očesa, ki so jim pravili tudi račke (Ophrys sp. ). Ko so prve kukavice odcvetele, so pričele cveteti več-

177 Informator VER.

178 Informator CAR.

179 Informator XMR, KHR.

180 Informator XMR.

I8I Informator KHR.

I82 Informator KHR.

183 Informator VER.

I84 Informator KHR.

I85 Informator CAR.

I86 Informator CAR. je kukavice z roza cvetovi (Ophrys sp. ). ${ }^{187}$ Raslo je več vrst kukuc, različnih barv, visoke ali nizke in kakor ugotavljajo - so do danes številna njihova rastišča uničena $\mathrm{z}$ sodobnimi kmetijskimi praksami. Okoli Remena in pri Žabljeku so v maju rasli visoki večcvetni zvončki. ${ }^{188}$ Spomladi so kukavice rasle po celotnem Remenu, sedaj, kot pravijo, le še v Podmališču. ${ }^{189}$ Rasle pa so na območju Remena, kot pravijo, tudi velikonočnicam podobne rože. ${ }^{190}$ Najverjetneje je šlo za isto vrsto, kot na ledini pri Dolgem grmu na drnovskem polju, kjer je izpričano nabiranje $z a$ spank $^{191}$ (Pulsatilla nigricans), ki so jim na Drnovem pravili fajfe. ${ }^{192}$

\section{Od Borovnic navzdol so travniki im. So- višče (Savišče), ki se stegajo na mrtviško in prav tam je največ podleskov. ${ }^{193}$}

Neznanokje na brižanskem so nabirali tudi encijanček ali bobke, kot so pravili encijanu ${ }^{194}$ (Gentianasp.).

$\mathrm{Na}$ bogatstvo in številčnost orhidej in drùgih rastlin na ubožanih travnikih ob Savi, kot jim pravijo nekateri domačini, in na pomen tega habitata v svetovnem merilu, je že pred leti opozoril Dušan Klenovšek (200I, II).

\section{Rastlinje za velikonočne in kresne šege} ter druge navade

Rastlinje, ki se je uporabljalo za velikonočne in kresne šege so nabirali skoraj izključno v poplavni ravnici. Tam so razen redkih izjem dobili vse potrebne sestavine.

$\mathrm{V}$ okviru predvelikonočnega obredja so ponekod v G. Skopicah za butaro za cvetno nedeljo $\mathrm{v}$ Vrbini iskali vrbove veje, bezeg in bršljan ( $\mathrm{He}$ dera helix). ${ }^{195}$ Tudi v vasi Brege so za butaro do-

$\begin{array}{ll}187 & \text { Informator EKC. } \\ 188 & \text { Informator EKC. Zaenkrat nedoločljiva vrsta. } \\ 189 & \text { Informator VKC. } \\ 190 & \text { Informator EKC. } \\ 191 & \text { Informator VKC. } \\ 192 & \text { Informator MIM. } \\ 193 & \text { Informator VKC. } \\ 194 & \text { Informator EKC. } \\ 195 & \text { Informator STM. }\end{array}$


bili večino sestavin v Vrbini. V butarici je moralo biti s leskovih šib, brin (gl. Hrana za ljudi...), bezeg in dren, vrh pa je bil ovit z žingrcem (zimzelen, Vinica sp. ). Brižani so pred cvetno nedeljo obiskovali tam edini, stari dren v bližini Save

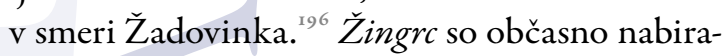
li tudi izven območja naše raziskave v Venišah, ${ }^{197}$ skonca Strgarjevega (izven karte na Sl. I), ${ }^{198}$ še zlasti ob žegnanjskih nedeljah in ob božjih poteh, ko so z njim okrasili vozove. ${ }^{199}$ Gorenji Skopičani so žingarc nabirali v pustih grmovjih na ledini Flančišče. ${ }^{200}$

Ponekod na Mrtvicah so butarco sestavljali iz bršljana, leske, dobroletine (Viburnum lantana), gabra (Carpinus sp. ), žingarca, farone in oljke. Pri opisih farone gre po mnenju Špele Pungaršek (Prirodoslovni muzej Slovenije) za navadno trdolesko - Euonymus europaeus (Pungaršek, Š., osebna komunikacija, 6. 5. 2016). Žingarc ali zimzelen je prej rasel na več mestih v bližini stoječih voda. Tako so ga Mrtvičani nabirali Pod belim bregom pri Vihrah, kjer ga je bilo še posebej veliko. ${ }^{201}$ Razen oljke, so vse sestavine našli v Vrbini, celo gaber. Zanj so npr. verjeli tudi, da varuje pred strelo. Zgolj za primerjavo in vtis navedimo, da Drnovci v okviru svojega spodnjega polja, ki je bilo tedaj že relativno suho, za butarico v njem niso našli vseh potrebnih rastlin, zato so jih iskali tudi drugod. Tako so žingrc nabirali v oddaljenem Trnovcu (izven karte na Sl. I), kakor so Drnovci imenovali konec doline potoka Žlapovec, tik pred njegovim nekdanjim izlivom v Savo v Krškem.

V G. Skopicah naj bi vsak pastir večer pred kresom (poletni solsticij) v Vrbini nalomil veje belega topola (Populus alba) in nabral šentjanževe rože: »Napravili so se šopi, da se je lažje nosi-

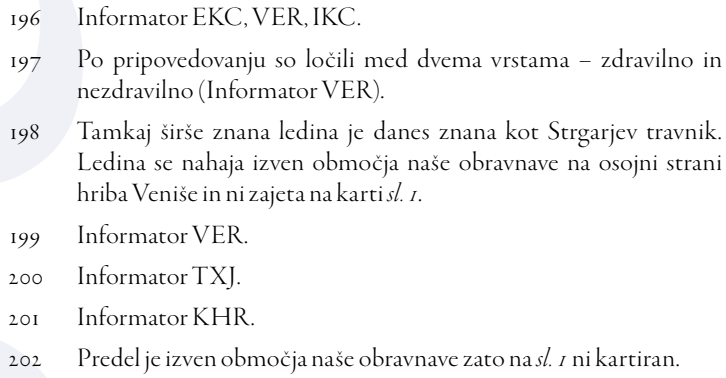

Predel je izven območja naše obravnave zato na sl. I ni kartiran.

lo domov. Veje so doma vstavljali za tesane stebre v plotu ob glavni vaški cesti. Iz šentjanževih rož pa smo vrh lat naredili preplet. In tako cela vas. Po treh dneh se je ves okras vrgel na domači gnoj. $\ll^{203}$ Isti običaj je izpričan tudi v vasi Brege, kjer so morali na predvečer kresa pastirji prinesti domov še pred sončnim zahodom rastlinje za krašenje vaških plotov.

Rož smo nabrali za polne naročaje - rume-
ne in bele kresne rože, ni bilo pravih kresnic,
pobrali smo vse kar je takrat cvetelo. Krasi-
li smo po plotih med latami, na stebre smo
pa šopke dajali in okrasili smo tudi krave, ki
smo jim rože napletli med rogove. ${ }^{204}$

$\mathrm{Na}$ plotove so napletali kresnice; nekateri so jih dajali le na stebre, drugi so iz njih napravljali preplete. Nekateri so ločili med $\gg$ belo $\ll$ in $\gg r u-$ meno kresnico «, obe pa so nabirali na ledini Remen in Gmajna. ${ }^{205}$ Nekateri pravijo, da je šlo v teh primerih za rože vrste lakota ${ }^{206}$ (Galium sp. ). Tudi na Drnovem so ob kresu krasili plotove $\mathrm{z}$ rastlinjem, ${ }^{207}$ vendar se potankosti o poteku niso ohranile. Vemo pa, da so drnovski koledniki sv. Jurija nalomili vrbove vejice za Savo, ki so jo po tem polagali na okna hišs. ${ }^{208}$

Količino paše so na Drnovem napovedovali po neki, $v$ času po kresu belo cvetoči in asparagusu podobni roži, na peščenih tleh pašnika Barovna. ${ }^{209} \mathrm{Na}$ brižanskih pašnikih so po bodeči neži (Carlina acaulis) napovedovali vreme.

Kurjenje ognja - kresovanje $\mathrm{v}$ času kresa (poletni solsticij) je bilo tesno povezano $s$ poplavno ravnico polja. Na Drnovem se je izvajalo na ledini Barovna, ${ }^{210}$ na Bregah v savski brežini pod vaško kapelico pri ledini Traminčki, ${ }^{211}$
203 Informator STM
204 Informator EKC.
205 Informator IFS
206 Informator EKC.
207 Informator VVK
208 Informator EDA
209 Informator TTR
210 Informator SVD, SJR, idr.
21 I Informator RVA, RVL. 
na Mrtvicah na ledini Barovna. ${ }^{212}$ Mesto kresa na Gorenjih Skopicah pa poleg ljudskega spomina izdaja kar toponim sam - Kresi, severno za t. i. Luznarjevo kapelico. ${ }^{213}$

\section{Druge uporabne rastline}

Brižani so poznali na močvirnih in vlažnih območjih tudi rastlino, ki so jo imenovali sić, ${ }^{214}$ $s_{i c ̌ k}^{215}$ ali sičjak ${ }^{216}$, rasel je pri ledini Globajnk s stalno vodo ${ }^{217}$ in pod Vrti, na ledini Pod vrbami pri Gmajni in v Ločici, ${ }^{218}$ kjer je zastajala voda. ${ }^{219}$ Kot zanimivost omenimo, da je na območju brižanskega spodnjega polja znana tudi ledina Sičjaki. Ime je izpričano za njive že na franciscejskem katastru leta 1824 , kot Sitschenyaki. ${ }^{220}$ Sičk, je bil zlasti cenjen med otroki - pastirji, zaradi dobrih lastnosti za vezavo in za pletenje. Rasel je na močvirnih predelih. Na paši so ga uporabljali za izdelavo igrač, pa tudi sicer. Pletli so iz njega izdelke za igro, kot so košarice, reziraparate in klobuke ter številne druge izdelke. ${ }^{22 x}$ $\mathrm{Na}$ Brižanskem - ugotavljajo domačini - danes ni več sička. Na podlagi vzorčnih stebel sička, ki jih je iz drugega rastišča priskrbela Elka Grilc iz Sevnice, je Špela Pungaršek (Prirodoslovni muzej Slovenije), ugotovila, da gre najverjetneje za sivozeleni loček (Juncus inflexus) (Pungaršek, Š., osebna komunikacija, IO. 5. 2016 in I. 7. 2016). $\mathrm{V}$ poplavni ravnici reke Sotle so sivozeleni loček imenovali šar (Kolbezen in Žagar 1978, 177). $\mathrm{V}$ zvezi z otroško igro in pletenjem igral se tam omenja tudi sitje, kot visokorasla trava ob Sotli (Počkar 1998, I05).

$\mathrm{Na}$ Bregah so poznali na mokrih tleh tudi rastlino im. flošc, $\gg$ visoko, ostro in grobo, sivo tra-

$\begin{array}{ll}212 & \text { Informator KHR. } \\ 213 & \text { Informator STM. } \\ 214 & \text { Informator EKC. } \\ 215 & \text { Informatorja EKC in VER. } \\ 216 & \text { Informator VKC. } \\ 217 & \text { Informator VKC. } \\ 218 & \text { Informator IFS. } \\ 219 & \text { Informator VER. } \\ 220 & \text { Glej franciscejski kataster za k. o. Drnovo - grafični del (mapni list } \\ & \text { VI) (gl. Literatura). } \\ 221 & \text { Informator EKC. }\end{array}$

vo, $\mathrm{z}$ večkrat preščipnjenim/zavitim steblom «. ${ }^{222}$ To so prinesli domov, jo poravnali v šop, ki so ga v dlani ovili v krog premera okoli $20 \mathrm{~cm}$ ter ga stisnili skupaj. Takšna priprava je nadomeščala krtače za ribanje tal. Bila je zelo trpežna, vendar zaradi grobosti za roke zelo neprijetna. ${ }^{223}$

O domači izdelavi krtač poroča Elka Grilc:

»sirkove krtače za ribanje tal. Iz nekih trav
je poiskal korenine, ki so bile bolj tanke, dalj-
še in rahlo kodraste. Te korenine je opral,
lepo zložil in namakal v vodi, da se niso po-
sušile. Iz teh korenin je naredil krtače, po-
dobne tistim, ki so jih prodajali in smo z nji-
mi ribali tla v hiši.

Šlo naj bi za korenine neke trave, ki je rasla na starih travnikih:

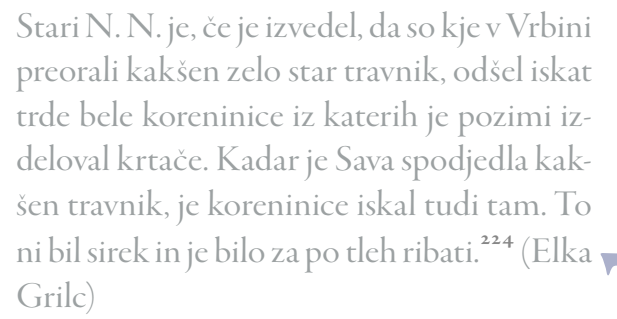

Poznali pa so tudi »temnosivo, tanko in ostro travo «, ki je na brižanskem v 30 -ih letih 2o. stoletja rasla le še na manjšem, mokrem odseku remenske struge na predelu Delečki. Ta »trava $\ll$ zaradi redkosti njenih rastišč ni bila več del splošno razširjene uporabe, ljudje pa so do danes pozabili njeno pravo ime. Zanjo pomnijo, da so jo generacijo starejši prebivalci z Breg še uporabljali za polnjenje štrozakov (ležišč) in komatov. Krave je namreč niso marale. Cenjena lastnost je bila ta, da se po sušenju ni sprijemala in je bila enakomerne sive barve. ${ }^{25}$ Domala ista uporaba je zabeležena v bližnji Kostanjevici na Krki za neko močvirsko rastlino, ki so jo tam imenovali plaščnka. Šlo je za manj kot meter visoko »travo«, ki so jo želi v gozdu in sušili, z njo pa polnili komate. Ker je bila čista in brez zeli so jo upo-
222 Informator VER, IFS
223 Informator VER, IFS
224 InformatorjaVER, IFS.
225 Informator VER 
rabljali tudi za polnjenje žimnic (Zakšek 2OI2, 30) in za izdelavo pastirskih plaščev, kakršne so nosili v tamkajšnji okolici (Makarovič 1960, 202; Mlakar 20I5, 65). Po mnenju Sonje Budna, gre za migalični šaš (Carex brizoides $\mathrm{L}$. ), ki so ga $\mathrm{v}$ Zakrakovju (izven karte na Sl. I) imenovali plaščenka ali tudi pleščinka, zanj pa so vedeli tudi na Drnovem (Budna, S., osebna komunikacija 6. ı.. 2016).

Franc Lovrenčak, v opisu prsti in rastja poplavenga sveta ob reki Krki ugotavlja, da tamkajšnje higrofilne rastlinske vrste, zlasti tiste iz rodu ločkov (Juncus. Sp. ), nimajo hranilnih lastnosti, travniki kjer rastejo pa naj bi imeli neznaten gospodarski pomen (Lovrenčak 1980, I40).

Zgoraj našteta pričevanja s Krškega polja, npr. da krave teh močvirnih trav niso marale ter opisi njihovih lastnosti, da se po sušenju niso sprijemale in so ohranjale barvo, sama po sebi govorijo o njihovi povsem drugačni, nekrmni uporabi. Pomen teh trav, torej vsaj za starejša obdobja, ne moremo videti skozi gospodarsko vlogo travnika kot takega. Zgoraj izpričani načini uporabe omenjenih trav, še v I. polovici 20 . stoletja, govorijo o drugačnih vrednostih tovrstnih travnikov, ki jih ni moč razumeti v današnji luči intenzivne izrabe.

\section{Nabiranje in uporaba drobnih živali}

$\mathrm{Na}$ paši v Vrbini so pastirji iskali čričkove rokav$c^{2} k e^{226}$ ali srajčke $e^{227}$, kakor so pravili pajčevinastim oblogam $\mathrm{v}$ rovčkih, ki so jih uporabljali za zdravljenje ran. Kot pripoveduje Elka Grilc, so rokavcke ali srajcke zbirali in jih imeli vedno tudi doma na zalogi za zdravljenje ran vseh vrst. Čakali so pred luknjo, dokler živalica ni prišla ven, nato pa so jo hitro odstranili, da ni mogla nazaj v luknjo. Živalica je bila hitra, obnašala pa se je zelo previdno. Segli so s prstom v luknjo in ven potegnili rokavček. Ti so bili dolgi približno Io $\mathrm{cm}$ in spodaj okroglo zaprti, kot naprstniki. Zunanja stran je bila blatna in prašna, znotraj pa gladka »kot pajčevina«. Notranjo stran so dajali na rane za zašcito in za obsušitev ter za boljše

\section{Informator EKC.}

227 Informator VER celjenje. $\ll^{228} \gg$ Pajčevino v zemljii $\ll$ so za celjenje ran kopali tudi na Drnovem in tamkajšnjih pašnikih. ${ }^{229}$

Po mnenju Tomija Trilarja (Prirodoslovni muzej Slovenije) ni šlo niti za črička (ta ne koplje lukenj) in niti za poljskega murna (ta koplje luknje, vendar nima predilnih žlez), s katerim bi utegnili zamenjati črička, temveč verjetno za pajka tapetarja ali vrečkarja iz rodu Atypus. Ta živi v kolonijah na travnikih in si izkoplje rov v zemljo, ki ga okrog in okrog obloži z mrežo im. »svilena vrečka«. O tem verjetno govori tudi potankost v zgornji navedbi, da so pred luknjo $\gg$ čakali « in ne $\gg$ bezali $\ll$ kakor pri murnih. Namreč v kolikor bi vanjo drezali, bi se pajek vanjo le še bolj odmaknil (Trilar, T., osebna komunikacija, 20. -21. 4. 2016).

O zdravilnih učinkih pajčevine je mnogo poročil. Krškopoljski identična uporaba »svilenih vrečk« pajkov vrste Atypus, za zdravljenje ran je izpričana v Južnih Karpatih (Wright in Goodacre 20I2, in tam navedena literatura). V Sloveniji je uporaba pajčevine etnološko izpričana predvsem za namene zdravljenja ran na koži; ureznin, oteklin in ustavljanja krvavitev (Sosič 2000, 224, 228, 231-232, 236 in 239). Ponekod na Dolenjskem za zdravljenje ran in zaustavljanje krvavenja navajajo pajčevino, ki so jo imenovali »marijini štumfki« (Sosić 2000, 217 in 244), na območju Kobarida pa »Matere Božje nogavice« (Sosić 2000, 233) ali v okolici Cerknega - »bohkove hlačce« (Sosić 2000, 240). V enem primeru z Dolenjske je razvidno, da je pajčevina izvirala tudi z neke rože (Sosić 2000, 217).

Vihrani so izvajali s pomočjo pijavk, ki so jih nabirali na ledini Spina/Struga tudi zdravljenje:

To so govorili stari ljudje. So šli in vzeli pijavko in če je imel vnetje zoba ali če se je vnela korenina, so si dali gor pijavko, da se je prisesala in bolno kri potegnila ven. To so počeli tukaj in še ne tako dolgo nazaj, so govorili. In enako tudi, če si imel kakšen tvor. ${ }^{230}$

228 Informator EKC

229 Informator BAS.

230 Informator PAT. 
Tudi na Bregah je bilo razširjeno zdravljenje s pijavkami. Izvajali so ga pri ljudeh s slabo prekrvavljenimi in nasploh slabotnimi nogami.

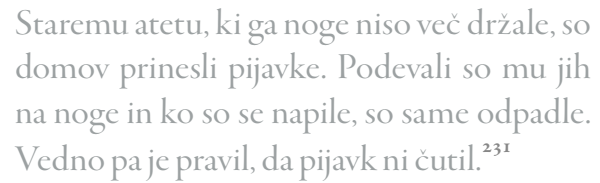

Na Skopiškem:

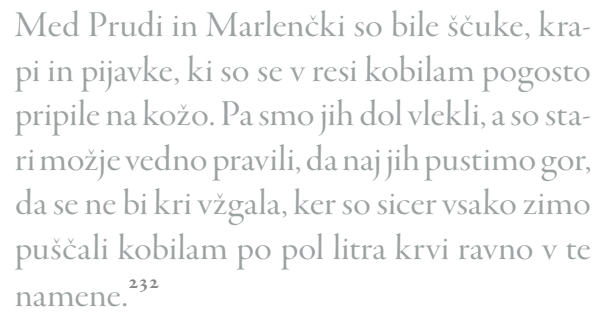

Stari ate, ki je bil rojen leta 1887 je pripovedoval, da so se na gorenjeskopiškem na predelu mrtvice Zlatič, zdravili s pijavkami na mestu samem. Pijavk je moralo biti na obolelih mestih ravno pravšnje število, kot so govorili stari možje. ${ }^{233}$

Nabiranje in raba zdravilnih rastlin ter pijavk na Krškem polju ima dobre primerjave v pregledu gradiva o ljudski medicini, ki so ga zbrale terenske ekipe SEM med 1948-1984 v Sloveniji (Sosič 2000). V obravnavanemu primerljivem okolju, kakršno je pokrajina ob Muri, najdemo našim zelo podobna poročila o ljudski medicini s pijavkami in rastlinami (Zadravec 1985, 130-131), naprimer pri zobobolu, krčnih žilah in ranah na nogah (Zadravec 2000, 59).

$\mathrm{Na}$ Bregah so ob stoječi vodi pri Pod vrbah in na vzhodnem delu Gmajn, na rastlinah, ki so jih imenovali »rdeči mlečki« nabirali velike pisane gosenice raznolikih barv $\mathrm{z} \gg$ rožičkom $\ll{ }^{234}$. Pripovedovalci pravijo, da je rumeno-rdeče cvetje delovalo dekorativno in kot se je zdelo, je vsak cvet imel svojo gosenico, ki so jim pravili tudi konjički. Vsaka gosenica je bila drugačna, vsaka lep$\check{s} a$. Opazovali so jih leže ${ }^{235}$ ali pa jih nosili domov,

$$
\begin{array}{cl}
231 & \text { Informator VER. } \\
232 & \text { Informator RCD. } \\
233 & \text { Informator TXJ. } \\
234 & \text { Informator VER. } \\
235 & \text { Informator EKC. }
\end{array}
$$

kjer so jih starejši družinski člani uporabljali za napovedovanje letine (česa bo več) in poteka zorenja žita, za kar sta govorili njihova barva in okras oz. pisanost. V zgodnjem poletju, $\mathrm{v}$ času pred žetvijo ječmena in pšenice, so bili pozorni na gosenice, na katerih je prevladovala rumena barva. Ker pa so za pšenico in ječmenom, včasih še tudi za ovsom, v poznem poletju sejali ajdo, so tedaj iskali takšne gosenice (iste vrste), ki so omogočale napoved količine ajdove moke. Zato so sedaj posvečali pozornost tistim, ki so imele več rjavkaste ali črne barve v podlagi. Črna barva ajdovih luščin je namreč pomenila več moke, rjava pa manj namlete moke. ${ }^{236}$ Tudi na Drnovem so na paši iskali gosenice s pikami in jih nosili kazati domov. Največ jih je bilo na pašniku Barovna. Posamičen vzorec je simboliziral določeno žito. ${ }^{237}$

Po mnenju Tomija Trilarja (Prirodoslovni muzej Slovenije) je verjetno šlo za gosenice navadnega mlečkarja (Hyles euphorbiae), ki se prehranjujejo na mlečkih (Euphorbia sp. ) (Trilar, T., osebna komunikacija, 20.-2I. 4. 2016).

Že pred drugo svetovno vojno so v Brežicah odkupovali polže, ki so jih v brižanski Vrbini v te namene tudi nabirali. ${ }^{238}$ Polži so se za prodajo tod nabirali še v 80 -ih letih 20. stoletja. Sicer pa so jih pred tem pekli tudi na paši.

\section{Lov}

$\mathrm{V}$ poplavni ravnici je bila številčna tudi divjad, ki je bila sestavni del občasnega jedilnika. Visoke divjadi pred drugo svetovno vojno tod še ni bilo ali pa je bila zgolj prehodna. Polje je še daleč v drugo polovico 20 . stoletja slovelo predvsem po zajcih in poljskih kurah; fazanih, jerebicah in prepelicah, pri čemer slednji vrsti od 1960-tih nista več lovni. Že Valvasor omenja na Krškem polju prisotnost velikega števila jerebic v povezavi s kulturno pokrajino in tudi njihov lov (Vlavasor 2010,246 in 248). Lov je bil pred povojno ustanovitvijo lovskih družin Krško in Cerklje ob Krki, predmet različnih zakupnikov (prim.

236 Informator VER, EKC in IFS

237 Informator BAS.

238 Informator EKC.

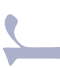

\section{O} (n) (n) 
Šribar 2018, 123-125). V 1930-tih so npr. na drnovsko spodnje polje zahajali zagrebški lovci, ki so bili v zimskem času nastanjeni na Drnovem. ${ }^{239}$ $\mathrm{V}$ okviru obravnavanega območja, njegovih naravnih danosti in $\mathrm{v}$ zvezi $\mathrm{z}$ Vrbino ter gospodarjenjem $z$ divjo perjadjo, omenimo domačina Franca Škofljanca z Breg, ki je kot vsestransko dejaven $\mathrm{v}$ povojnih letih znatno pripomogel pri vzreji in povečanju staleža jerebic. Nadaljeval je tudi kinološko tradicijo dr. Vilka Pfeiferja iz predvojnega časa, ko je na Bregah leta 1962 ustanovil psarno nemških kratkodlakih ptičarjev $\mathrm{z}$ zvenečim domačim imenom »Vrbinska $\ll$, ki je aktivna še danes (B. T. 201 4, 464).

Povrnimo se obravnavanem času prve polovice 20 . stoletja. T. i. krivolov je bil prisoten predvsem v sebenjkovskih pa tudi v nekaterih kmečkih družinah. Tema je zanimiva in bi zahtevala širšo razpravo, zato se tukaj omejimo le na kratek pregled lovskih dejavnosti brez naprednih lovnih pripomočkov, ki so bile $\mathrm{v}$ domeni pastirjev $\mathrm{v}$ Vrbini. Izjema so le opisi lova s kamni, ki ga opisujemo v odstavku o Prodnikih (gl. Prodniki).

Pastirji predvojnih in tudi povojnih generacij, so spremljali premike različnih divjih živali, zato so lahko pravočasno dostopali do jajc zlasti poljskih kur, od mladičev pa so cenili zlasti golobje, grličje, sračje in vranje, seveda v času njihove največje tolstosti, to je tik pred vzletom. Drobovje so otrebili na kraju samem, meso pa sprali $v$ reki ali v mlaki ${ }^{240}$ ter ga spekli na ognjišču, ki je bilo večinoma stalno, v bližini kakšnega večjega drevesa, npr. vrbe. $Z$ gnezd, večinoma poljskih kur, nabrana jajca so dolenjeskopiški pastirji pekli na ognjišču, ki so ga oblikovali iz blata. V prvem desetletju po vojni so v te namene, pa tudi za peko rib, na območju dolenjeskopiške Spince že uporabljali pleh, navadno pridobljen iz tamkajšnjih letalskih razbitin. ${ }^{241} \mathrm{~K}$ temu spomnimo še na peko polžev, ki smo jih omenili že v poglavju o nabiralništvu (gl. Nabiralništvo). Prehrana z ježi je tod izpričana v času krize

239 Nformator DLJ.

240 Informator TXJ.

24I Infortamtor ZHK. prvih povojnih let, ${ }^{242} \mathrm{v}$ poplavni ravnici, na ledini Pod vrbam pa je izpričana v 1930-tih letih v prehodnih romskih taborih. ${ }^{243}$

Velika biodiverziteta nekdanjega okolja se je odražala v bogastvu živali neposredno ob reki Savi in v ravnici ob njej. Sočasen vpogled dajejo nekatera poročila, ki pričajo o obilju lovno zanimivih živalskih vrst. $\mathrm{Z}$ območja levega brege Save so znani zanimivi opisi lovnih vrst živali Ferdinanda Ripšla iz I880-tih let (2007, I55I58). V Savi je bila v 1930-tih letih do Sevnice npr. še kečiga (KLDB 1937, 239 in 288). Stanje živega sveta $\mathrm{v}$ kasnejšem, poregaulacijskem obdobju in problematiko njegovega dolgoročnega obstoja, prikazujejo številne raziskave (npr. Klenovšek 1999; 2001; 2009; Vogrin, M. in Hudoklin 1993; Hudoklin 1993; 2008).

\section{Lesne surovine}

$\mathrm{Na}$ vihranskem, ${ }^{244}$ brižanskem ${ }^{245}$ in skopiškem za obravnavano obdobje kot pomembne omenjajo različne vrste vrb (Salix sp. ) ter topolov (Populus sp. ), med njimi jagend (Populus nigra, jagned) in topolovko, kakor ljudsko imenujejo beli topol (Populus alba), kjer izpostavljajo njegovo svetleče listje in mehak les. Omenja se tudi hrast dob (Quercus robur), vendar je bil tedaj že redko drevo. Jesenovim drevesom na Vihrah pravijo jesenovc (Fraxinus sp. ), manjši gozdič tam še danes uspeva na območju Petrove škarpe severno od ledine Zgorelo, na Bregah pa ob robu Gmajne in med Delečki. Od drugih listavcev omenjajo še črno (Alnus glutinosa) in belo jelšo, ${ }^{246}$ lipo (Tilia sp. ), murvo (Morus alba in Morus nigra), gacjo ali hacanko (Robinia pseudoacacia) in brest (Ulmus sp. ). ${ }^{247}$ Jelše so bile na skopiškem nekdaj zelo razširjene in kjer jih najdemo še danes. $\mathrm{Na}$ Brižanskem so jelše rasle na ledini Velike vode in na ledini Delečki, kjer je običajno zastajala voda

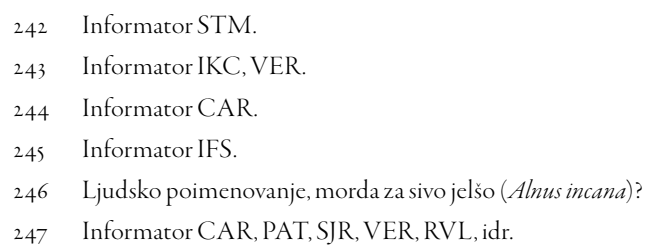


t. i. leskovškega potoka Pašenka. ${ }^{248}$ Jeseni je njegova voda po starih savskih strugah, preko ledine Ločica in Delečki, pritekala vse do zaledja vasi Brege (Rihter 2015, 56 in 262-263). Drnovci so do jelševine prihajali na ledini Zlatičje šele po tem, ko so tam prišli do novih zemljišč v prvi polovici 2o. stoletja. ${ }^{249}$

\section{Grmovnice}

Grmovne vrste so bile zelo razširjene na jarkih in nasipih, ki so omejevali pašnike ter v mejnicah, predvsem pa na pašnikih. Ob poteh v zaledju Breg in Mrtvic so mejnice varovale pred ubegom živine na travnike in na njive. $V$ brižanskih mejnicah spodnjega polja posebej omenjajo vrbo, trnulj (Prunus spinosa), glog (Crataegus sp., tod ljudsko hrušca in redkeje medvedove hruške) ter lesko (Corylus avellana).

Na starih prodiščih - pašnikih (ledini Gorenji prudi in Dolenji prudi) so na skopiškem in brižanskem (Mali in Veliki prudi) kopali za prodajo korenine češmina (Berberis vulgaris) za barvanje tkanin. ${ }^{250} \mathrm{Na}$ skopiškem, vihranskem in brižanskem se omenja nabiranje brinovih jagod in vej (gl. Nabiralništvo). Na Drnovem so vejevje črnega trna za potrebe ograjevanja vrtov in krpanja dotrajanih plotov sekali v mejnicah na spodnjem polju. V zvezi s tem je zanimivo pričevanje o vaški podobi v času druge polovice 20 -ih let in $\mathrm{v}$ tridesetih letih preteklega stoletja:

Planke, malo zagrajeno ali pa iz protja spleten plot in zopet malo zagrajeno/.../ s tem je bilo veliko dela, naš ate - vem, ker smo morali gredo za hišo ograditi - so šli in nasekali tarnula - tarnulavo tarje,25I po tem pa smo s tem pletle ograjo. / ... /, si se takoj nadrl na trnje (Rihter 2015,169-170).

248 Informator EKC

249 Informator BAS

250 Informator VER, IKC, EKC, IFS, STM, idr. Na tem mestu opozarjamo na napako v avtorjevem članku iz leta 2010 (Rihter) na str. 30, kjer bi moralo namesto »kopali korenine jasmina (Rihtzer 2010, 30), pisati »kopali korenine češmina «!

251 Narečno poimenovanje za črni trn (Prunus Spinosa). Tarnulavo tarje, v pomenu trnje črnega trna. Tod razširjeno poimenovanje zanj je tudi darnul, čeravno ne gre za drnulje drena.

\section{Jagned}

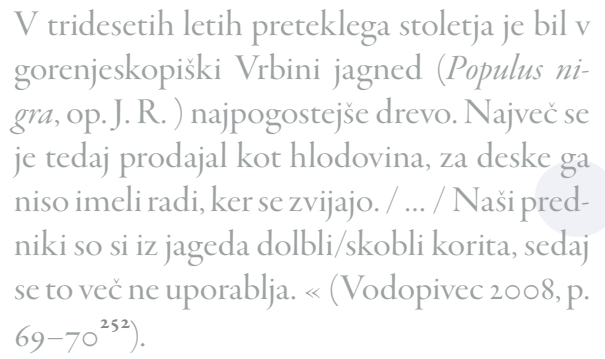

O njegovi nekdanji razširjenosti na vihranskem priča tudi toponim Pod jagnedom, ki je izpričan že leta $1824^{253}$ in je živ še danes v obliki Mali in Veliki podjagend. $\gg$ Iz jagnedovega lesa so na skopiških domovih dolbli korita različnih dimenzij za različne potrebe. « (Vodopivec 2008, p. 69$\left.70^{254}\right)$. To je lahek in močan les, a le če je bil na suhem. Zaradi prepletenosti z žilami ga ni bilo moč kalati, temveč je bil izvrsten za dolbenje. ${ }^{2}$ $\mathrm{Na}$ Vihrah so dolbli manjša, polkrožna korita za prestrezanje črev ob kolinah, ki so jih imenovanih nejcke oz. bance. ${ }^{256} \mathrm{Na}$ D. Skopicah so jagned uporabljali za izdelavo manjših sani, iz njegove skorje pa so otroci rezljali igračke (Rihter 2010, 30). Uporaben je bil tudi kot gradbeni les. $\mathrm{V}$ vasi Vihre še danes najdemo nekatere skednje, ki so obiti s krivimi jagnedovimi deskami (Rihter 20I0, 30). Na Bregah so iz jagneda izdelovali gajbice za hranjenje poljščin in za izdelavo zgornjih delov voza; konic in skončnikov ${ }^{257}$, predvsem pa so tod izdelovali predmete, ki so služili delu z žitom in moko. Takšna sta npr. vijavnica in skledasto polkrožno korito za mesenje kruha - banca. Prav takšne, odslužene bance, so otroci tod uporabljali za spuščanje po snegu. ${ }^{258}$ To je omogočala njihova nič manj skrbno kot notranjost, lepo zaobljena zunanjost (nehorizontalno

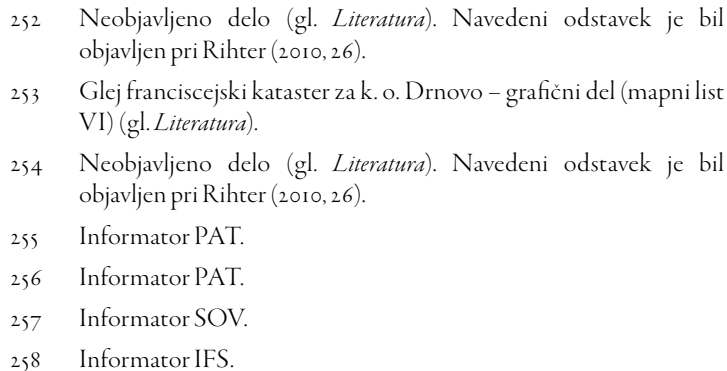


dno). V času po 2. svetovni so v vihransko Vrbino prihajali potujoči rezbarji iz Slavonije (ali Srbije in Madžarske), ${ }^{259}$ ki so od domačinov kupili jagnedova drevesa, jih posekali in na mestu samem mesec in več dolgo izdelovali različne okrasne motive (npr. živalski motivi), ${ }^{260}$ ter druge izdelke, npr. korita in bance. ${ }^{261}$

$\mathrm{V}$ luči današnje podobe nekdanje poplavne ravnice dodajamo, da so bila najjugozahodneje $\mathrm{v}$ poplavni ravnici dokumentirana tri jagnedova drevesa na holocenskih terasah pri vasi Brege, na meji ledin Traminčki in Flančišče (SL. 2). Ta so imela po izročilu veliko prostorsko in simbolno vlogo, saj naj bi bila simbolično potaknjena na mejo med pašnikom in vaško zemljo (Rihter 2015, 239, Op. 343). Izročilo pravi, da je praded Jurečič iz Breg pri določanju meje med pašniki in njivami šel k takratnemu jagnedovem drevoredu ob cesti, nalomil veje, jih prinesel $\mathrm{k}$ meji in jo označil tako, da je vejice potaknil v linijo. Tri zaporedne vejice naj bi vzklile in zrasle v velika drevesa, ki so jih ohranili kot mejnike. Izročilo še pravi, da so to pomembno dejanje razmejitve polja od pašnikov, ob veliki udeležbi vpletenih, obilno »zalili $\ll \mathrm{z}$ vinom. ${ }^{262} \mathrm{Ob}$ komasaciji zemljišč je prišlo leta 2013 do menjave lastništva in posledičnem nepričakovanem poseku le-teh, nakar se je prebudil tudi ljudski spomin o njihovi nekdanji vlogi, ki smo ga zapisali zgoraj. Danes sta za Bregami na območjo Barnopak in nekdanje Gmajne še dva manjša jagneda, nekaj več pa jih je bilo še na skopiškem v smeri vihranske ledine Prudi. ${ }^{263}$

Današnje stanje. Osrednji del obravnavanega področja je med leti 2009 - 2014 zajela komasacija, ki je povsem spremenila kulturno pokrajino spodnjega polja. Zabrisana je parcelacija in ustroj poti, ki je izviral še iz fevdalne dobe. $\mathrm{Na}$ območju spodnjega polja med Vihrami in Brega-

Informatorji niso bili enotni v navajanju narodnosti. Nekateri omenjajo potujoče Rome. Vilko Novak je v etnografski študiji na območju Prekmurja ugotovil, da so korita in posode iz jagnedovine tam dolbli Romi (Novak 1947, I20).

260 Informator IFS

26I Informatorja CAR in PAT.

262 Informator RVF.

263 Informator PAT. mi v obsegu komasacije so (ne)posredno izginile številne mejnice na vihranskem (ob poti na relaciji Brodišče-Zgorelo), na brižanskem (Hančave lastine, Stara gmajna, Zavrbenice, Naša vrbina) ter večina starih markantnih osamelcev, npr: edini hrast na ledini Pod vrbe, edini hrast na ledini Naša vrbina, osamelci različnih vrst vzdolž Velikega savišča, že omenjeni trije mejni jagnedi na meji ledini Traminčki/Flančišče (gl. Jagned) (Rihter 2015, II-I4), tod najstarejši osameli glogovi drevesi (!) nad Podmališčem. idr. Omenjenemu neprimerljivo in večje uničenje naravne in kulturne pokrajine pa je pomenila izgradnja akumulacijskega bazena za HE Brežice, ki - po savski regulaciji - pomeni doslej najradikalnejši poseg v dosedanji obrečni prostor (prim. Hudoklin I993; 2008, i-iii; Brečko 2008).

\section{Hrast}

Pričevanja o gospodarski izrabi vrbinskih hrastov so redka. Vemo, da jih vrbinski pastirji niso marali za kritje $\mathrm{v}$ slabem vremenu, zaradi strel. ${ }^{264}$ Razpolagamo pa s podatki o svinjski paši pod hrastovimi drevesi in uporabi za zdravljenje (gl. Zdravilne ...). Zanimivo je pričevanje o hrastu, kot pomembnem mejniku na spodnjem polju brižanske vrbine, nekje na območje ledine Borovnice in Stare vačke, kjer je potekala vzhodna poljska meja med vasjo Brege in Mrtvice.

Brižani smo pasli do Struge, ${ }^{265}$ kjer je v stru-
gi tekel majhen potoček, nekje ob meji z
mrtviškim. Tem potočku smo rekli Struga.
Tam, na meji je rasel osamelec, edini hrast
od Zavrbenic naprej, za katerega nihče ni
vedel koliko sto let star je bil. Zraven hrasta
je bila struga, ki je danes ni več in do tam
smo smeli pasti. Stal je na meji med našim in
mrtviškim. Tako je pripovedovala stara ma-
ma, ${ }^{266}$ ki me je enkrat peljala do tega drevesa
in mi je pokazala mejo. ${ }^{267}$
Informator FSI.
Natančneje nelociran toponim. Zelo verjetno gre za
mikrotoponim znotraj ledin Malo in Veliko savišce ali v njuni
neposrednibližini.
Informator EKC. Stara mamaje umrla leta i94ov starosti 83 let.
Informator EKC.

267

\section{4}


Stari Mrtvičani so namreč kričali, če je živina ušla preko meje. ${ }^{268}$ Ta potoček, bržkone zarisuje že t. i. avstrijska vojaška specialka iz leta 1882 in v nadaljnih letih vse do leta $1943 .{ }^{269}$ Po tej karti je gotovo, da je izviral in tekel po strugi na ledini Veliko savišče, ki jo predstavlja star meanderski lok oklepajoč ledini Borovnice, Stare vačke in druge. Verjetno je šlo za podobne okoliščine, kot pri potočku, ki je izviral na ledini Studenec na gorenjeskopiškem (gl. Ribolov).

Jelsa

Uršula Vodopivec je zapisala:

\section{Jaged je v Vrbini najpogostejše drevo, bolj na mokrem svetu pa jelše (Alnus sp., op. J. R. ). $\mathrm{V}$ prejšnjem stoletju je raslo še veliko število vrb. Sedaj so se posušile. (Vodopivec 2008, p. $\left.69-70^{270}\right)$}

Kot že omenjeno, so jelše obraščale remensko strugo na brižanskem spodnjem polju, na predelu Delečki. ${ }^{271} \mathrm{Na}$ G. Skopicah so jelšev les uporabljali za tla v živinskem hlevu, ki so ga cenili zaradi trajnosti v mokrem okolju (Vodopivec 2008, p. $\left.7 \mathrm{I}-72^{272}\right)$. Na Bregah je hlev Vinka Škofljanca, zgrajen leta I900, ki ima še vedno deloma originalen jelšev tlak iz $20 \mathrm{~cm}$ dolgih in v premeru I2 $\mathrm{cm}$ širokih prečnih rezin jelševih debel. Stari rejci naj bi izdelovali izključno tovrstne pode, saj so na podlagi izkušenj menili, da takšna tla živini in konjem zagotavljajo varno vstajanje, predvsem pa z svojimi robovi in medprostori onemogočajo drsenje nog. Podoben učinek razgibanosti in opore $\mathrm{v}$ tlaku hlevskih tal so dosegali s tlakovanjem z velikimi prodniki in lomljenci. Ostanke takšnih izvedb tal smo pred leti še lahko videli na nekaterih domačijah, npr. pri stari p. d. Rahličevi domačiji na Bregah (gl. Prodniki).

$\mathrm{Na}$ skopiškem so $\mathrm{v}$ poletnih mesecih kurili jelšev les, ker ta ni imel posebne kalorič-

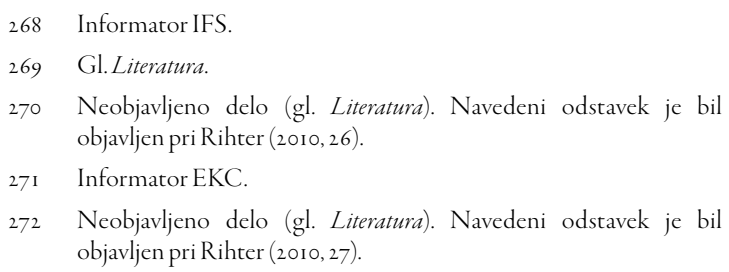

ne vrednosti (Vodopivec 2008, p. 7I-72). Jelševina za poletno kurjavo je znana tudi iz drugih poplavnih ravnic (prim. Novak 1947, I17). Na brižanskem se je jelševina $\mathrm{z}$ Velikih vod prodajala mizarjem, ki so jo cenili npr. za izdelavo obročkov za karnise. Na Bregah je izpričana njena uporaba tudi za platišča vozov. ${ }^{273}$

\section{Jesen}

Jesenov (Fraxinus sp. ) les so na Vihrah cenili za izdelavo delov vozov, na Skopicah so ga uporabljali za izdelavo smuči s postopkom kuhanja in uvijanja (Rihter 2010, 30), podobno na Bregah in Vihrah. ${ }^{274} \mathrm{Na}$ splošno pa je bil tod priljubljen za izdelavo raznih ročajev. ${ }^{275} \mathrm{Na}$ Bregah so jesenovino sekali v Zlatičju, jo skobli in s pomočjo toplote in šablon ukrivljali za smuči. Sicer pa je bila tod jesenovina nepogrešljiva za špice voza in za kosišča. ${ }^{276}$

\section{Vrbe}

Med drevesnimi vrstami po omembah izstopa obilje različnih vrst vrb (Salix sp. ), ki je postalo ob savski regulaciji še izdatnejše. Osnovni naravni gradniki za utrjevanje savskih brežin so bile namreč vrbe oz. t. i. vrbove fašine. ${ }^{277}$ Vrbe so na savskih obrežjih sicer rasle samoniklo, na reguliranem kanalu pa sprva kot posledica utrjevalnih del, gojene pa naj bi bile bile tudi $\mathrm{v}$ nasadih (D. Skopice) (Rihter 2007, 35; 2010, 30, 35-36; op. 23 in 43; 2015, 69). Nasade in porasle brežine so »savski mirkači < kakor so na Bregah pravili čuvajem savskih obrežij, čuvali pred nenadzorovanim sekanjem. To bi namreč ogrožalo trdnost brežin. $\mathrm{Na}$ ta način so varovali tudi naravne zaloge za izdelavo novih fašin za utrjevanje spodžrtih brežin. ${ }^{278}$ Neupravičeno rezanje vrbovih šib v Vrbinah pod Zotterjevo pristavo (severno od Žadovinka), navaja Majda Smole po graščinskih

273 Informator IFS

274 Informator IFS, RVL, PAT.

275 Informator CAR.

276 Informator RVF, IFS.

277 SSKJ: fašina -e ž (i) grad. butara protja za dreniranje ali utrjevanje rečnih bregov.

278 Informator IFS 
arhivih Šrajbarskega turna (Smole i980, 9I). Šlo je za organizirano službo varovanja in popravljanja spodžrtih brežin, za katere nosilca se je v ljudskim spominu ohranilo poimenovanje savski inženir ali inšpektor. Na Bregah se v tej vlogi v 19. stoletju omenja Škofljanec. Kot izvajalec del oziroma savski delavec pa Završnik. ${ }^{279} \mathrm{~V}$ Dolenjih Skopicah je o tej dejavnosti ohranjen spomin, da so ljudje iz vasi hodili na delo v brežiški grad, kjer so pletlifašine ${ }^{280}$ za utrjevanje brežin. Na območju Čateža pa naj bi delavci vodne skupnosti tovrstne fašine izdelovali še v 1960-tih in 1970tih, ${ }^{281}$ kjer je od leta 1938 dalje kot rečni načelnik deloval Franc Avšič (Teppey 1977, 29). Ugotavljamo, da bi bilo pred desetletji možno v tu obravnavanih vaseh še pridobiti prvoosebna pričevanja o načinu in poteku tovrstnih del predvsem na skopiškem območju, kot jih omenja Uršula Vodopivec (2008).

Ljudem so tako negovani, mladi obrežni nasadi vrb izjemno ugajali za pletarstvo v okviru domačih potreb. Zaradi periodičnih človekovih utrjevalnih posegov ob reki, so se stari nasadi pomlajevali, hkrati pa nastajali novi. Tako je bilo primernega materiala - maldic - vedno dovolj. Tudi v času pred rečno regulacijo, si lahko verjetno predstavljamo podobno izobilje samoniklega vrbja, ki je ob spremembah rečnih strug, kot pionirsko, poraščalo vedno nova prodišča in brežine. Že pred 2. svet. vojno so na Skopiškem vrbove šibike nabirali za prodajo, kupci pa so bili razni korbarji, ki so pletli korbe za blagoslov velikonočnih jedi; manjše korbe $\mathrm{z}$ locnjem, cekarje za raznovrstno rabo in tudi stole (Vodopivec 2008, p. 69-70 $0^{282}$ ). K tej omembi pritegnimo še poročilo iz tedanjega Brežiškega okraja, objavljeno v Slovenskem gospodarju, ki pravi, da so leta I90 I zaradi velikega zaledja $\gg$ vrbin $\ll$ z vrbami, $\mathrm{ki}$ jih je bilo v nekaterih občinah od 40-60 oralov

\footnotetext{
279 Informator VER, EFF, STM.

280 Informator TXJ.

28I Informator TXJ.

282 Neobjavljeno delo (gl. Literatura). Navedeni odstavek je bil objavljen pri Rihter (2010, 26).
}

in so jih do tlej kupovali italijanski kupci, celo razmišljali o ustanoviti pletarske šole. ${ }^{283}$

Še zlasti je bila tod priljubljena vrsta im. zlatikona ali zlatika (Salix sp.). Njene enoletnice so cenili za izdelavo špal in za pletenje košar. Rasla je na savskih obrežjih, največ pa so je nabirali na ledini Zlatičje, ki naj bi po ljudskoetimološki razlagi dobila ime prav po zlatiki oz. zlatikoni. Zlatikono Brižani opisujejo kot vrsto vrbe, ki je pod lubjem rumene barve in so jo cenili za izdelavo špal in za pletenje.

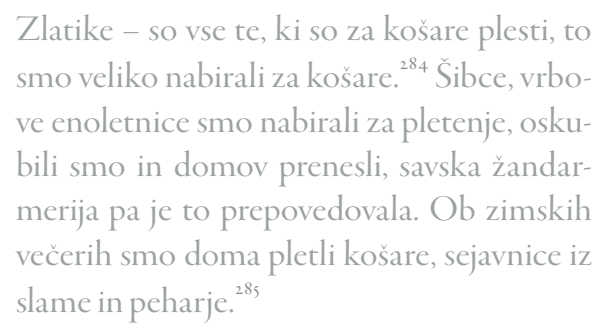

Sicer pa je bila izdelava špal pogosto delo pastirjev na paši, ki so s žepnimi nožiči klali vrbove veje, ${ }^{286}$ izdelovali pa so jih tudi iz maklena.

Tudi pletar Bogolin z Mrtvic - ki ga na Krškem polju kot prodajalca košar, košev in jerbasov pomnijo na drnovskih in drugih sejmih, ${ }^{287}$ je svoje surovine pridobival $\mathrm{v}$ poplavni ravnici. Imel je namreč svoj vrbov nasad v stari strugi pod vasjo. ${ }^{288}$ Njegov repertoar izdelkov je natančneje opisala Ljudmila Bras. Izdeloval je koše in košare iz surove, nebeljene vrbe, pisane locnjevke, bele jerbase toplarje z dvojno kito, košare za perilo, zibke in koše za mošt (Bras 1970, II).

Od brižanske vrbine in Zlatičja gorvodno, v smeri Krškega, kjer so bili osušeni savski tokovi že dokaj oddaljeni od regulirane struge, so v I930-tih določene predele že prodajali za posek zlatike $\mathrm{z}$ namenom oskrbe s kurjavo. Iz vzhodnega dela tega območja je znana tudi lomenjena edina Zlatičje, ki naj bi po ljudskoetimološki razlagi dobila ime prav po zlatikoni. S takimi po-

\footnotetext{
283 Slovenskigospodar, 28. I I. I90 I.

284 Informator VKC.

285 Informator EKC.

286 Informator EKC.

287 Informator TTR.

288 Informator IFS
} 
seki so dopolnjevali oskrbo z drvami, še posebej tisti, ki niso imeli lastnih gozdov v krakovskih gozdovih. $^{289}$

Vrba, beka (Salix viminalis) in še neka druga vrsta vrbe $\mathrm{z}$ od beke boljšimi lastnostmi za vezavo, je bila tedaj še povsod osnovna surovina za vezavo v vinogradništvu. Na Drnovem so jo poleg tega, uporabljali tudi za žlimaje/žlemaje svinjskih črev. ${ }^{290}$ Brižanski pastirji so izdelovali veliko izdelkov iz mladega vrbovega lubja, pezde$c e$, piščalke in rogove. ${ }^{291} \mathrm{Na} \mathrm{D}$. Skopicah so tako izdelan rog imenovali horn ${ }^{292}$ (Rihter 20I0, 30), prav tako na Drnovem. ${ }^{293}$ Uršula Vodopivec piše, da so jim med vojno, ko so bili izgnani v delovna taborišča v Nemčijo, Kočevarji posekali vse domače beke na dvorišču in po vrnitvi iz internacije niso imeli s čim vezati. Zopet so se zatekli v Vrbino, a tam, niso več dobili dovolj kvalitetnega šibovja za vezavo (p. 69-7094). To pomanjkanje bi bilo možno razložiti s tem, da med okupacijo na določenih odsekih ni prihajalo do rednega pomlajevanja nasadov $\mathrm{z}$ utrjevanjem brežin, zaradi česar tudi ni bilo ustreznih mladic za pletenje ali vezavo.

\section{Leska}

V brižanski vrbini ob poti čez ledino Remen, na razdalji med Delečki in Zaromani so bili pred izgradnjo letališča Remen (tj. pred letom 1937 , prim. Ravbar 2008), na obeh straneh poti, z grmovjem poraščeni jarki z nasipi. Ti so varovali pred ubegom živine na travnike. V tej mejnici je bila najbolj zastopana vrba, črni trn, glog in leska (Corylus avellana). Tu so spomladi nabirali leskove šibe $\mathrm{v}$ mezgu za pletenje košar $\mathrm{z}$ locnjem in jerbasov za velikonočni žegenj in jerbasov za prenašanje dojenčkov. Pravočasno olupljene leskove šibe so bile bele barve, kar je dajalo izdelkom posebno vrednost. Belina jih je izvzemala iz vsakodnevne rabe; takšni izdel-

$\begin{array}{ll}289 & \text { Informator IKC, VER. } \\ 290 & \text { Informator MIM, SJR. } \\ 291 & \text { Informator EKC. } \\ 292 & \text { Horn ali rog je bilo glasbilo (trobilo). } \\ 293 & \text { Informator SJR. } \\ 294 & \begin{array}{l}\text { Neobjavljeno delo (gl. Literatura). Navedeni odstavek je bil } \\ \text { objavljen pri Rihter (2010, 26). }\end{array}\end{array}$

ki so bili ponekod v uporabi le ob praznikih. ${ }^{295}$ Uporabljali so jo tudi za izdelavo špal za špiljenje klobas ${ }^{296}$ in nosilnih kolov za dimljenje mesa. ${ }^{297}$ Nekateri Brižani so za nosilne kole pri dimljenju uporabljali tudi drenov les (Rihter 20I0, 30), ki naj bi ga po nekaterih podatkih sekali nekje na Gmajni in pri nekaterih hišah uporabljali tudi za špale, ${ }^{298}$ enako kakor maklenov les (Rihter 20ı, 30). Iz leske so izdelovali locnje za ribolov z mrežo na križ. Izbrane kole premera do $4 \mathrm{~cm}$ so ukrivili tako, da so jih z obema koncema potaknili v zemljo in pustili nekaj dni (gl. Ribolov), da so se ukrivili. Pastirske palice so bile iz leske in praviloma okrašene z vzorci napravljenimi z izmeničnim izrezovanjem lubja. ${ }^{299}$ Leska je bila po vseh vaseh nepogrešljiva za koljenje visokih sort fižola, v otroški igri pa za izdelavo lokov. ${ }^{300} \mathrm{O}$ široki uporabi leske govori naslednji odstavek:
Stric je prepletene biče delal - lesen del je iz leskove palice, zgornji del je grel in klal. Izde- loval je še vitre. En del leskove palice je od- luščil in ga obdeloval nato pa v snegu puščal, da se ni posušilo. To so vitre. Izdeloval pa jih je iz par metrov dolgih kolov, ki jih je dal v peč, olupil, nato pa z nožem luščil par mili- metrov na debelo, nato pa spet in spet luščil, da je dobil tanke vitre. Na usnjenem kolenč- niku jih je z nožem fino obdelal. Nato pa jih je dal v sneg, da se niso izsušile. Ostanki leske so bili za locen. Košare je delal nato iz viter. Tako narejene košare so bile za na njivo in za vse iz njive domov prinesti. Koši so imeli šir- še vitre. Za sejanje so bile košare iz slame, im. sjavence. Pozimi je pripravil še brezov les za popravila na plugu. Grablje so prav tako na- redili iz leske, vse iz Vrbine. ${ }^{301}$

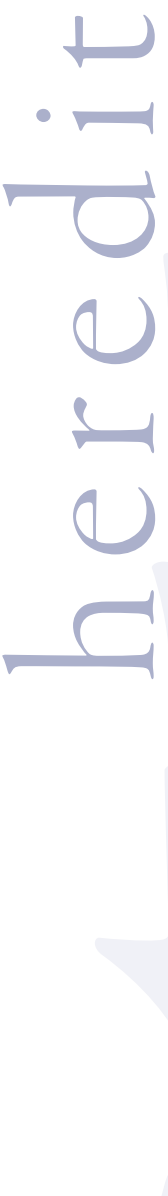

295 Informator VER

296 Informator VER

297 Informator IFS.

298 Informator IFS

299 Informator EKC.

300 Informator SJR.

301 Informator EKC. 
Na Drnovem so iz leske izdelovali mreže za sušenje lanu in konoplje kot delov zidanih sušilnic. ${ }^{302}$ Gradili pa so na Drnovem tudi iz protja pletene in z ilovico ometane peči za sušenje lanu. ${ }^{303}$

\section{Stelja}

Grabljenje stelje na skopiškem v tridesetih letih preteklega stoletja omenja Uršula Vodopivec:

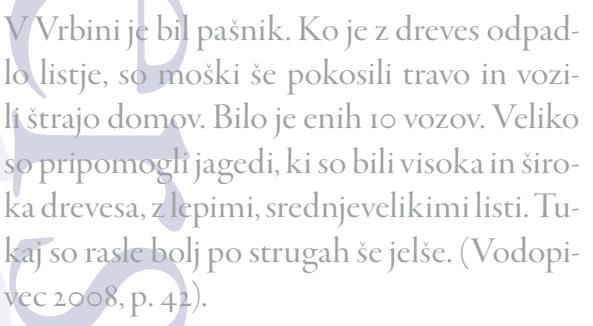

Na brižanskem pašniku Gmajna, kjer so izvajali skupno pašo navpreko, čeravno na razparceliranih delcih, so vsako jesen vse kmetije opravile še čistilno košnjo za steljo, a sedaj le v okviru svojih parcel. S tem so pašnik pripravili na počitek še pred zimo. Šlo je za nekoliko obraslo travo v šopih, ki se je obrasla od poletja le okrog gladeža in drugih bodečih ali živini neokusnih rastlin. Takšna stelja ni bila cenjena, saj pogosto poročajo o poškodbah rok z rastlinskimi bodicami.

\section{Polajc in gladiž rasteta na Gmajnah, tega je bilo veliko in kačji stric. Za steljo je bil vmes, vendar gaživina ne mara. ${ }^{304}$}

Vrbinske stelje tisti z gozdovi v Krakovskem gozdu niso potrebovali, saj so obilnejšo strajo dobili kar tam. Zato so jesensko/predzimsko košnjo na Gmajnah odstopali tistim, ki niso imeli drugih možnosti za pridobivanja stelje. Ta košnja je bila sicer nujna predpriprava pašnika za drugo leto in je zato vselej moral dočakati zimo očiščen. ${ }^{305}$

\footnotetext{
302 Informator STA

303 Informator ALS.

304 Informator VKC.

305 Informator VER in IFS.
}

\section{Gradbeni materiali}

\section{Ilovica}

$\mathrm{Na}$ Bregah so koristili ležišča ilovice za domače potrebe na ledini Globajnk, na Vihrah na ledini Pod belim bregom in na ledini Prudi. Nobeno ležišče danes ni več vidno oz. odprto. Znano je, da je šlo za manjše kope na mestih, ki so jih naznanjala močvirna območja. Koriščenje ilovic je jenjalo s pričetkom 2. svetovne vojne oz. s povojnimi spremembami v načinu gradnje. Zato tu danes ni nobenega ohranjenega kopa več. Zanimala pa nas je primernost ilovic za opisane in druge potrebe. Odgovore so ponudila opažanja v neposredni bližini znanega starega kopa v Globajnku, in sicer na sosednji ledini Podmališče, ki ju povezuje ista struga. Nedavno je tamkajšnji izkop za vodovod na liniji Brege-NE Krško, pokazal, da se pod I,5 $\mathrm{m}$ pretežno poplavnih muljastih peščenih naplavin pričenja naplavina mazave sive ilovice $\mathrm{z}$ vključki rjavo obarvanih peg. ${ }^{306}$ Enaka ilovica je prisotna tudi na Drnovem pod vasjo, na prvi terasi im. Zevniki, kjer se na okoli $2 \mathrm{~m}$ globine, pod čistimi ponekod pa pod muljastimi peščenimi naplavinami, pojavi do I $\mathrm{m}$ debela naplavina ilovice, ki se useda neposredno na peščenoprodnati zasip. Prehod med njima pa je obarvan rjavordeče v debelini okoli Io $\mathrm{cm} .{ }^{307}$ Poizkusi so pokazali, da je to ilovico možno oblikovati in tudi žgati. Sklepamo, da je na Bregah in na Vihrah šlo za izkoriščanje opisanim podobnih naplavin ilovice.
Na brižanskem v Globanjku je bila rjava gli- na. Naša stara mama so jo hodili iskat za bru- ne fugirat v skednju. Notri so dali ovsene ple- ve in to z nogami zmesili do gostote testa za kruh. S to zmesjo so spomladi, ko se je oto- plilo, zafugirali vse reže v tleh in stenah ske- dnja. Mi smo doma vršili žito v skednju s kra- vami ali konji in smo potrebovali zatesnjena
Vidno dne, 27. 12. $2013 \mathrm{v}$ več izpraznjenih jamah, ki so bile izkopane ob naknadnem odkopu spojk že položenih vodovodnih cevi na celotni trasi sicer ravnokar položenega vododvodnega voda na območju struge Podmališče, do poti Žadovinek-Velike vode (avtor prispevka).
307 Takšno situacija je bila dokumentirana dne 13. 5. 2009, na liniji izkopa za kanalizacijo preko njiv ledine Zevniki (avtor prispevka). 
bruna, da žito ni uhajalo. To je imela pri nas stara mama čez. Tam v Globajnku, kjer so kopali glino je v jami ostajala voda - tam smo verjeli, da prebiva povodni mož. Tudi lesene hiše iz brun so zamazali s to glino, le da so jih pobarvali še z modro in belimi pikicami. $^{308}$ Kadar pa je na svinjakih odpadel omet sva s staro mamo, s prav tako zmesjo ilovice in plev ter s pomočjo kalanih leskovih palic kot armature, popravile poškodbe. ${ }^{309}$

V Globajnku so Brižani jemali ilovico tudi za zdravljenje rdečike pri prašičih. Umešali so jo z vinskim kisom in mazali po koži. ${ }^{3 \mathrm{IO}}$ Kaleš, raztopino kravjega blata in ilovice, ki so ga na Bregah uporabljali za presajanje krmne pese na strnišče (gl. Flančǐ̌če), ${ }^{311}$ so prav tako pripravljali iz ilovice iz Globajnka. ${ }^{312}$

$\mathrm{Na}$ Vihrah so v Margečevi strugi Pod Belim bregom Vihrani dobili »sivo blato «, ki so ga uporabljali za zamazovanje tal $\mathrm{v}$ hišah (za praznike so tla poflikal ${ }^{13}$ ) in za tesnenje prostora, kjer so mlatili žito in so ga na Vihrah imenovali uguna (gumno). ${ }^{314}$ Kot še pravijo na Vihrah, so »posebno zemljo《 ali »rjavo glino za izdelavo tal v zgradbah nekdaj kopali tudi na ledini Prud. Njena ležišča so naznanjali predeli na katerih je zastajala voda, kopali pa so do I m globoko. ${ }^{315}$

O še nekem mestu, kjer so prvotno najverjetneje kopali ilovico, kasneje pa (izpričano) predvsem pesek in prod, morda priča ledinsko ime Brnokop na Skopiškem in temu zvočno podobno ime Brnopake ali Barnopake na brižanskem. Besedo brnokop razlaga L. Pintar, kot kraj kjer se koplje prst ali ilovica za tlakovanje (Pintar i895, 4). V narečni slovenski besedi brn pa je ohranjen pomen $\gg$ rečno blato, mulj $\ll$, brna $\gg$ ilovica, zemlja, humus« (Snoj 2009, 82-83). V Pleteršnikovem slovarju najdemo brnje, kot die Dammerde

\footnotetext{
308 Informator VER, ELK.

309 Informator ELK.

3 Io Informator VER.

3I I Informator IFS.

312 Informator IFS.

313 Informator CAR.

314 Informator CAR.

315 Informator RMI
}

v nemščini ${ }^{316}$, kar Ivan Zelko pri obravnavi Prekmurskih ledinskih imen prevaja kot »črna prst« (Zelko 1985, 460). Kopanje rodovitne zemlje za rož $e^{317}$ ter peska in proda je izpričano na Bregah, ob robovih ledine Barnopake, ki je toponim za staro strugo. V njej je ob zahodni brežini, pod teraso Vrti, potekal pas srenjskega zemljišča, ${ }^{318}$ kjer so imeli vaščani po izročilu odprte manjše skupne kope proda. Med njimi so bili nekateri opuščeni že pred 2. svetovno vojno, saj so vanje že takrat odvažali hišne odpadke. ${ }^{319} \mathrm{Na}$ ledini Barnopake so v grmovju kopali humozno zemljo za rože in druge domače posevke še $\mathrm{v}$ 90-ih letih 20. stol. ${ }^{320}$ Vzdolž nasprotne, zahodne brežine Barnopak, so imeli pred 2. svetovno vojno pas majhnih gojitvenih vrtov-flančišč, ${ }^{321}$ ki naznanjajo prehod Barnopak $\mathrm{v}$ obširno ledino Flančišče proti zahodu (Gl. Flančišče).

Kopanje na ledini Brnokop na skopiškem dodatno osmišlja ljudski spomin na že pred letom 194I odprte kope; omenjata se dve jami, ${ }^{3}$ kasneje pa je to področje prečkala avtocesta in danes niso več vidni. Zaenkrat žal ni natančneje znano, kaj so v omenjenih jamah kopali.

V Gorenjih Skopicah so (v času velike noči) glino za lesene hiše fugirat ${ }^{323}$ kopali za vasjo na Stazah. Šlo je za sivo glino, ki so jo mešali z pšeničnimi plevami. O primernem ležišču ilovice za izdelavo opek priča tudi v izročilu ohranjen podatek o obstoju opekarne na vzhodnem robu Dolenjih Skopic, ${ }^{324}$ kjer so v letih 1900 in 1901 izdelali vso potrebno strešno in zidno opeko za izgradnjo nove cerkve sv. Marka v Cerkljah ob Krki, kakor poročajo domačini ${ }^{325}$ in župnijska kronika (objavljena pri: Smuković 20I4, 243).

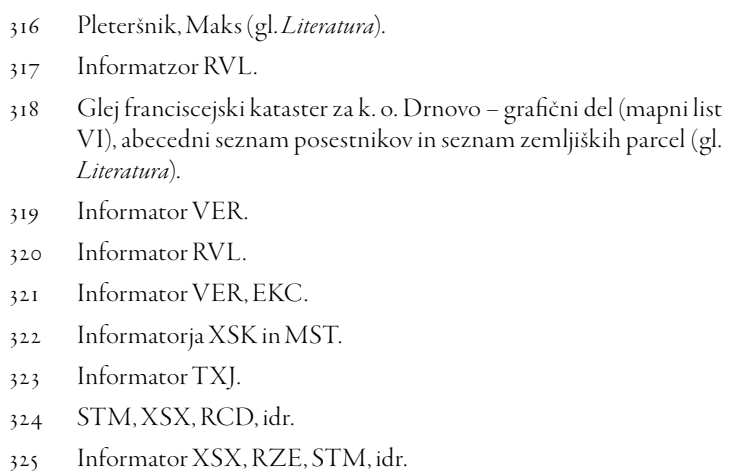


Lokacija opekarne sovpada z arheološkim najdiščem Dolenje Skopice - Arheološko najdišče Ravne, kjer naj bili nekateri ostanki kamenja, opeke in lončenine, prepoznani kot rimskodobni. ${ }^{326} \mathrm{Na}$ tem mestu, ki so ga značilno imenovali Ciglana, so domačini dobili

\section{ilovko za mazat po hišah. ${ }^{327}$ Ciglarna je bla tu, rekli so Pod črešje. Bil je ohranjen še kos zida. Se je vidlo od deleč. ${ }^{32}$}

Ta podatek se nanaša na čas 1930-1940. Opekarna pa naj bi po mnenju nekaterih prenehala $z$ delovanjem že pred I. svetovno vojno. ${ }^{329}$ Krajevni leksikikon dravske banovine $(1937,258)$ omenja opekarno tudi v Gorenjih Skopicah.

\section{Sviž in prod}

$\mathrm{V}$ vseh obarvnavanih vaseh se je pred drugo svetovno vojno droben pesek, ki ga tod imenujejo sviž, črpal izključno na spodnjem polju (holocenske terase). Prod pa se je v tistem času kopal ob glavnih cestah predvsem za njihovo oskrbo in to skoraj izključno na pleistocenski terasi. Pogosto so se kopi nadaljevali kar na robovih starejših kopov, v katerih so sicer že uspevali travniki in njive. Med njimi so namreč v okolici Drnovega nekateri zelo verjetno še rimskodobne starosti (Rihter 2015, 209-216).

Za ceste so skrbeli domači zogarji, ${ }^{330}$ ki so - kot že rečeno - prod črpali v nekaterih starih kopih, hkrati pa so deloma že odpirali tudi kope na svojih zemljiščih v bližini cest (npr. Brege). Nove kope so odpirali v času okupacije tudi Nemci predvsem na območjih, kjer so gradili t. i. avionske ceste, $s$ katerimi so povezali glavno letališče v Cerkljah ob Krki, z zakloni za letala na poraščenih obrobjih polja bližje reki Savi. Večji kop proda je v tem času (med okupacijo) na novo nastal južno od c. sv. Urha na ledini Pri križi ${ }^{33}$, ki je trenutno $v$ fazi zasipavanja. $V$ času okupa-

Dolenje Skopice - Arheološko najdišče Ravne (EŠD I0779)): Dostop: http://giskd6s. situla. org/giskd/ (17.08. 2019).

327 Informator RCD

328 Informator STM

329 Informator TXJ

$330 \mathrm{~V}$ pomenu cestni delavec.

33 Informator FSI, VER, EXC, LPT, XSX cije so zaradi umeščanja avionske ceste pri ledini Mrtvišce, znatno povečali tudi kop proda pri Bregah na mestu, kjer je kasneje domovala »gramoznica in cementnine Brege « kasneje del IGM Sava Krško. ${ }^{332}$ Do takšnih posegov v brežino in prod, je med 2. svetovno vojno prišlo tudi na Vihrah na ledini Drašca. ${ }^{333}$

Ko je po drugi svetovni vojni prod postal prevladujoč gradbeni material za zidavo, so se nekdanji obcestni kopi zaradi ugodne prometne lege nesluteno razširili daleč onkraj nekdanjih meja. Za nazornejšo ilustracijo - na drnovskem zahodnem robu se je stari kop proda, ki je še leta 1824 meril 7 arov, do danes povečal za 1600-krat (Rihter 2015, 174), na Bregah je južno od vasi takšen kop uničil več kot 42 ha dotedanjih njiv. Med Drnovim in Gorenjo vasjo pa skoraj 6oha. Samo na razdalji $\mathrm{I}, 5 \mathrm{~km}$ med Bregami in Drnovim, je bilo od 1970-tih let in do danes trajno uničenih več kot Iooha nekdanjih njiv. Na neodgovorno in kratkovidno gospodarjenje Krške občine $z$ umeščanji kopov proda na ekološko krhko ravnico, je že leta 1977 opozarjal Albin Stritar (Stritar 1977, 637), vendar so se od tlej nekatere gramoznice še razširile.

Posvetimo se sedaj pregledu razvoja kopov sviža na spodnjem polju, ki nas tu najbolj zanimajo. Če so se kopi proda vidneje razširili šele po sredi 20. stoletja, je za kope sviža, ki so vezani izključno na spodnje polje, značilno, da so se razmahnili že konec 19. in v začetku 20. stol. Ta trend v okviru Drnovega povezujemo z obnovami drnovskih pogorišč (prvič po lesenih gradbenih fazah), v zidani izvedbi z opeko. Drnovo je namreč med leti 1899 in 1915 , torej v samo 16-letnem obdobju gorelo kar devetkrat, do konca druge svetovne pa še najmanj $3-\mathrm{krat}$. Izmenoma so pogoreli skorajda vsi vaški predeli, nekateri tudi po večkrat in to v istem letu (Rihter 2015, I70). Povečane potrebe po svižu so ta čas zaznavne tudi v drugih tukajšnjih vaseh in so povezane $\mathrm{z}$ novim načinom gradnje $\mathrm{v}$ opeki in izdelavi značilnih glajenih fasad pogosto oker barv, $\mathrm{z}$ dekorativnimi elementi še zlasti ob odprtinah ali

332 Informator VER, IFS

333 Informator LPT 
nišah v zatrepu ali na vogalih, katerih glavna sestavina je sviž. Takšne zgradbe naj bi po izročilu v zimskem času gradili krškopoljski zidarji, ki so sicer gradili zagrebško secesijo. ${ }^{334}$ Dejavnost opekarstva na bližnjem brežiškem prostoru je raziskala Ivanka Počkar (2000, 200ıa). Manj znane pa so območju naše obravnave bližnje opekarne, nekatere med njimi sicer mlajšega nastanka, v vasi Gorica, Pristava, Velika vas in Gorenja vas (prim. Pirc 2014, 162, 165; Rihter 2014, 48; Horvat 2014,200 in 211 ).

Iz izročila vemo, da navkljub velikim potrebam po mivki, srenja Drnovega pred 2. svetovno vojno ni dopuščala nekontrolirano črpanje sviža, četudi pogorelcem iz sosednjih vasi. Vendar je bil istočasno tudi $\mathrm{v}$ drugih vaseh urejen nadzor nad skupnimi resursi na gmajnah (Rihter 20II, 4: op. 26; 2015, 173-174). O redu pri upravljanju s skupnimi viri oz. črpanju drnovskega sviža posredno priča tudi vzorna urejenost srenjskega kopa na Barovni, kot ga prikazuje fotografija Drnovega, avtorja Vekoslava Kramariča, zajeta med leti 1928-1947. ${ }^{335}$

Spodnje drnovsko polje je torej na prelomu iz I9. v 20. stoletje, s povečanimi kopi sviža na Barovni, postopoma pričelo pridobivati drugačno podobo. Več kot $2 \mathrm{~m}$ debeli nanosi kvalitetnega sviža so znani predvsem na relaciji DrašceBarovna-Flančišče. Srenjski kopi na Barovni pa so bili izkoriščani še na pragu tretjega tisočletja. Kot rečeno, imajo hiše iz preloma I9. v 20. stoletje, širom Krškega polja, že glajene notranje omete ter zunanjo fasado, za kar vse so prvič po obdobju lesenih gradenj potrebovali izdatne količine kvalitetnega sviža. Ta ni smel vsebovati organskih primesi, še zlasti ne premoga. Relativno starejše holocenske terase - kakršne tu, v bližini vasi, nedvomno so - ustrezajo temu pogoju, saj v času njihovega oblikovanja, v srednjem savskem toku še niso izpirali premoga. Povpraševanju po kvalitetnem svižu so zlasti po drugi svetovni vojni sledili posamezniki, ki so odprli kope kar na svojih njivah (Drašce, Blog, Mali blok), po razdelitvi nekaterih delov srenjskih pašnikov pa po-

334 Informator VRD.

335 Kramarič, Vekoslav (gl. Literatura). novno tudi tam - vzhodni rob Barovne na meji z ledino Flančišče in na Mali barovenci. V času izgradnje vojaških kasarn v Cerkljah ob Krki leta 1947-48 in nekaj let za tem še ob gradnji tamkajšnje nove vzletno-pristajalne steze, so se tudi na Drnovem pričeli odpirati privatni kopi sviža na dotedanjih njivah, kar je še danes vidno v obliki poglobljenih njiv predvsem na ledini Drašce, Blog in Za mlako. ${ }^{336}$ Med starejše kope sviža na drnovskem spodnjem polju lahko štejemo tiste na Barovni, zelo star kop proda in tudi sviža je bil v Gaugah na severnem obrobju drnovskega spodnjega polja, ki je izpričan že na franciscejskem katastru (Rihter 2015, 174 in 255).

$\mathrm{Na}$ brižanskem območju spodnjega polja so kopali sviž na ledini Zarbenice ali Zavrbenice. Za prod je bil na brižanskem odprt kop na meji med zgornjim in spodnjim poljem na ledini Mrtvišce. ${ }^{337}$ Sviž se je kopal tudi na ledini PlišZaroman, kajti iz tamkajšnjih predelov bližje toku Save ni bil uporaben za vsakovrstno zidavo, zaradi vsebnosti premogovih delcev. ${ }^{33^{8}} \mathrm{Na}$ Drnovem so pravili, da v nasprotnem - če se tak sviž s primesmi premoga uporablja za fine izravnave - iz sten kasneje »premog ven tolče «, torej, da na beležu pušča madeže (Rihter 2010, 29 in 2015, 172).

$\mathrm{Na}$ zgoraj omenjeni ledini Pliš-Zaroman lahko sledimo enemu največjih, še ohranjenih ročnih (!) kopov mivke na obravnavanem območju. Gre za ročni površinski kop nemških vojaških ujetnikov, ki so z nakopanim svižem in zemljo izravnavali tukajšnje rezervno travnato vojaško letališče Remen v povojnem času. ${ }^{339} \mathrm{~S}$ to informacijo dopolnjujemo leta 2012 izraženo napačno domnevo, da je tod morda šlo za strojno odstranitev, zelo velike, več kot 0,5 ha velike površine (Rihter 2016d, 249-250).

Na skopiškem so kopali sviž na ledini Malenček oz. Marlenček (Rihter 20IO, 29). Uršula Vodopivec v zvezi s kopi sviža omenja širše območje Skopiškega zaliva: »Moj oče pa, če je ra-
336 Informator JZJ.
337 Informator IFS, VER
338 Informator VER.
339 Informator FSI 
bil sviž doma, se je zapeljal na Gorenje cesarsko in tam v bližini našega tala (op. a., tj. Gorenjega cesarskega in Skopiškega zaliva) in Save, kopal jarek kot kolovozno pot proti Savi. Ko je bila leva stran že usposobljena za prevoz, se je lotil še desne strani. In tako, kos za kosom, in je bilo že izhodišče gotovo. / ... /. « (Vodopivec 2008, p. 65$\left.66^{34 \circ}\right)$. Na Skopiškem poznamo še več kopov iz povojnega obdobja, za katere še ni povsem gotovo ali njihovi pričetki segajo tudi v predvojni čas. Tod je izpričana tudi uporaba sviža v hlevu kot izravnava za jelšev tlak (gl.Jelša).

Poleg uporabe v gradbeništvu, so sviž pogosto uporabljali tudi v gospodinjstvu, npr. za zasipavanje korenja v kleteh. ${ }^{3+\mathrm{I}} \mathrm{Na}$ Bregah so železni jedilni pribor ali bištek, ki je rjal, čistili z svižem, prav tako cilindre petrolejk in litre (steklenice) ter nasplošno rjaste železne predmete. Petrolejkin cilinder se je ob svižu pral tudi s koprivami v vodi. ${ }^{342} \mathrm{Na}$ Drnovem se je sviž uporabljal kot primes pri zasipu za sajenje sadnega drevja in trt na zgornjem polju (pleistocesnka terasa).

$\mathrm{Na}$ Vihrah poznamo še lokacijo starega kopa proda, na ledini Zgorelo, ki ga je preko izročila možno posredno tudi datirati. Izročilo pravi, da naj bi tu kopali zemljino in prod med izgradnjo tamkajšnje t. i. Petrove škarpe. Material so uporabljali za izdelavo nasipa, ki so ga nato tlakovali s kamenjem $^{343}$ (Rihter 2016b, 152). Verjetno je bil kop kasneje še deloma izkoriščan, a glede na morfologijo terena (globina, oblika dna in sten) se je videlo, da vanj nikoli ni posegel strojni izkop. V času zaključne faze komasacije zemljišč, je bil ta kop pred nekaj leti zasut.

\section{Prodniki}

$\mathrm{V}$ vseh vaseh je v starejših gradnjah (kadar gre za kamnite zgradbe) zaslediti tudi večje prodnike (velikosti $30 \mathrm{~cm}$ in več) $\mathrm{v}$ temeljih, $\mathrm{v}$ manjši meri celo $\mathrm{v}$ polnilu sten zidanih zgradb. $\mathrm{Za}$ omenjene dimenzije prodnikov vemo, da jih je moč $\mathrm{v}$ večjih količinah dobiti le $\mathrm{v}$ rečnih strugah in

340 Neobjavljeno delo (gl. Literatura). Navedeni odstavek je bil objavljen pri Rihter (2010,26).

34I Informator TTR

342 Informator VER.

343 Informator CAR. še to ne na vsakem prodišču. So pa bila ta pred stoletjem vsekakor številčnejša in predvsem lažje dostopna. V starih hlevih ponekod še vidimo tlake iz velikih prodnikov (Brege) im. kugle. Tu in tam vidimo tudi manjša tlakovanja pod napušči ali pred vhodi v bivalne in gospodarske objekte ali pa nanje naletijo ob prenovah. Dotrajani stebri plotov so ponekod zagozdeni z večjimi prodniki. Ker na območju obravnavanih vasi lomljen kamen naravno ni prisoten, razen konglomerata $\left(V_{i h r e}{ }^{344}\right)$ ali pa je prisotnost kamenja povezana $\mathrm{z}$ arheološkimi najdišči v bližini, so tod za uteži pri kisanju zelja in repe uporabljali predvsem večje prodnike. Nabiranje teh v izročilu ni vezano na kope proda, saj ročni površinski kopi navadno niso dajali prodnike željene velikosti in s tem povezane teže, če že, pa so bili redki in morda tudi neprimerni. Predvsem niso smeli biti apnasti. ${ }^{345}$ Morda so prav zato poročanja o iskanju kamnov za kisanje vedno vezana na predele ob reki Savi, ${ }^{346}$ kjer je bila izbira neprimerno večja:

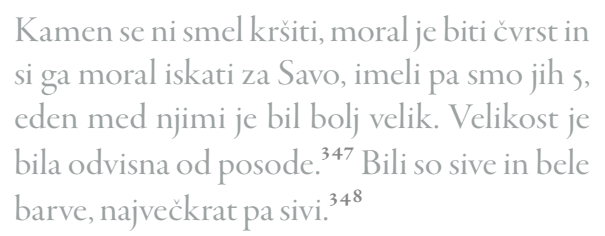

Za navajanje kokoši na stalno gnezdo so odbrali lep prodnik bele barve, ki je posnemal obliko in velikost pravega jajca. Takšen kamen so na Drnovem imenovali podlošk, v uporabi pa je lahko bil desetletja dolgo. ${ }^{349}$ Navadno je šlo že na videz za »lepše « prodnike, gladkih in skladnih površin, večinoma bele barve po obliki in velikosti podobne kurjemu jajcu. Na nekdanjih ${ }^{350}$ savskih prodiščih pa so takšni, med navidez veliko izbiro vendarle ne tako pogosti. Na starih dvoriščih in kmetijah jih je zavržene v okolici gospo-
344

345

346

347

348

349

350

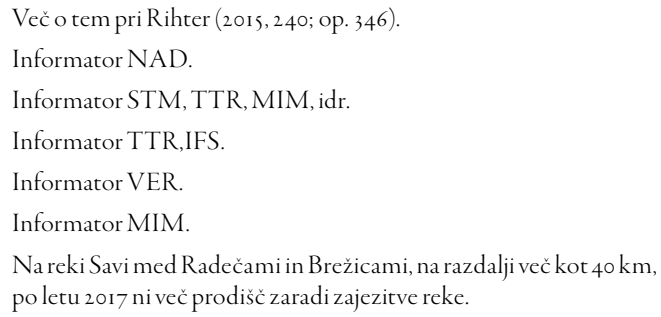


darskih poslopij (npr. pod nadstreški, kapom, ipd) možno pogojno prepoznati po zgoraj omenjeni obliki, v izjemnih primerih (v suhih kontekstih) pa tudi po še ohranjenih drobcih jajčnih lupin, ki so ostali z jajčno vsebino prilepljeni na površino kamna, kot posledice razbitja.

Vse pastirske igre, ki so vključevale tudi kamne (npr. kotlanje), so zahtevale lepo izbrane, navadno bele prodnike. ${ }^{351}$ Pastirji so s prodniki zaščitili pred živino (oz. njenim žrtjem) tudi svojo obleko na prodiščih med kopanjem v Savi. ${ }^{352}$ Odraslo divjo perjad, predvsem nekoliko večje fazanje mladiče so nekateri lovili z metanjem skrbno odbranih prodnikov velikosti okoli $5 \mathrm{~cm}$. Te so nabirali na zalogo ob priložnosti povsod, nosili pa so jih v žepu (gl. Lov). ${ }^{353} \mathrm{Na}$ ravno »lepo « oblikovani prodniki, predvsem pa kremenovi - za katere so pravili, da so za ogenj kresiti $^{354}$ - so vedno pritegnili pozornost in tako pogosto našli prostor tudi doma, čeravno zgolj v okras, kjer so se porazgubili po dvorišču. Sem sodijo tudi prodniki s predrtinami. Še zlasti oblike, ki so funkcionalno posnemale kakšna orodja, npr. brus ali sekiro tu in tam še najdemo po domovih za okras. Nekatere prodnike, ki so jih našli za Savo, so uporabljali tudi za brušenje domačega rezalnega /sekalnega orodja. ${ }^{355}$

\section{Pred zaključkom}

$\mathrm{V}$ obravnavanem obrečnem prostoru smo zabeležili tudi številne druge oblike človekove prisotnosti in njegovih dejavnosti. Ena teh je npr. prestrezanje premoga, o kateri za spodnje Posavje podrobneje beremo $\mathrm{v}$ raziskavah Ivanke Počkar (2009) in pri Živku Šebku (2010). Tu so še nabiranje naplavljenega lesa, ki pri Srednjem Marofu v Žadovinku izprčano sredi i 8. stoletja (Valenčič 1965, I87-I88) in pričevanja o kupčijah s savinjskimi flosarji in razdiranju flosov $\mathrm{v}$ brižansko-mrtviški in vihranski vrbini, ${ }^{356} \mathrm{ki}$ se

351 Informator EKC.

352 Informator EKC

353 Informator MIM.

354 Informator SJR.

355 Informator MIM, IFS.

356 Informator RMI, MRT kot trgovanje s Štajerskim lesom na Savi v Krškem, omenja že sredi i8. stoletja (Valenčič 1965, I88). Nadalje smo zabeležili spomine na poplave, brodarske in druge nesreče povezane $\mathrm{z}$ reko Savo, ${ }^{357}$ vojaške nesreče, ${ }^{358}$ poškodbe in smrti z ubojnimi sredstvi, ${ }^{359}$ pastirske igre, ${ }^{360}$ plutje po poplavljenem polju ter pričevanja o kmetijski in drugi škodi ${ }^{361}$ ipd. Tudi ti vidiki, ki jih na tem mestu podrobneje ne predstavljalamo, posredno dodatno pričajo o človekovem gibanju v tem prostoru. Tem se pridružujejo še razne vojaške dejavnosti, med njimi avstroogrsko vojaško topničarsko strelišče (Brenčič et. al. 2003, 52) in druge, kasnejše vojaške dejavnosti na relaciji Žadovinek - D. Skopice (Rihter 2016d, 247-248). Mnogo je tudi jarkov in nasipov, med katerimi so nekateri ostanki vojaških aktivnosti (Rihter 2015, 261, op. 413), drugi pa razmejitvenih del, pogosto med pašniki in njivami (Rihter 2015, 239, Op. 343, 264).

$\mathrm{Na}$ drugi strani so tu še pričakovane dejavnosti, ki pa jih zaenkrat (še) nismo odkrili v ljudskem spominu, v naravi pa jih težje prepoznavamo zaradi številnih sprememb v načinu kmetijske obdelave površin, vendar jih poznamo od drugod. Takšno je naprimer navodnjavanje travnikov, ki je izpričano v le kakšna $2 \mathrm{~km}$ oddaljeni Stari vasi onkraj Save (Ripšl 2007, I58). Ta način gospodarjenja s travniki, ki je zajemal tako namakanje kakor tudi gnojenje, je bil dobro dokumentiran npr. $v$ porečju Pšate (Radinja et al. 1976, II3). V zaledju vasi Brege ga na pašniku Gmajne in na predelu Velikega Savišča, na podlagi nekaterih topografskih znakov zaenkrat zgolj domnevamo $v$ sicer neznani preteklosti.

V vseh vaseh so izstopali posamezniki z velikim repertoarjem specifičnih znanj in potankosti povezanih s poplavno ravnico; npr. s poznavanjem nekdanjih značilnosti travnikov in pašnikov ter tamkajšnjih trav in rož na obeh

357 Informator ZHK, VER, EKC, IFS, SJR, idr.

358 Informator SJR, IKC, ZHK,idr

359 Informator VER, EKC, FSI, SJR, idr.

360 Informator VER, EKC, VVK, idr.

36I Informator DIN, DIT, STM 
bregovih reke Save, z sposobnostmi natančnega slikanja preteklih podob parcelacije, nekaterih zgodovinskih dogodkov, mest osamelih dreves in nekdanjih vodnih površin do natančnega poznavanja obsegov ledinskih imen in drugih zanimivosti. Mnogi med njimi budno opazujejo spremembe $\mathrm{v}$ poplavni ravnici že 8 desetletij in so neprecenljiv vir informacij o nekdanjem življenju tukajšnjega človeka. Tozadevno izpostavimo Elko Grilc, rojeno na Bregah, ki je bila v 1930-tih letih vrbinska pastirica, in ki še vedno spremlja pokrajino nekdanjega pašnega zaledja vasi Brege. Plod poznavanja in zanimanja za domače okolje Vrbine so tudi dokumentirani vsi večji vodostaji, ki jih na D. Skopicah že desetletja fizično beleži Jože Račečič p. d. Šavarč in so vidni v tamkajšnjem avtocestnem podvozu.

Obseg predstavljenih znanj in dejavnosti v poplavni ravnici, kaže tudi druge, neagrarne vidike človekove prisotnosti, ki jih ni moč prezreti. Takšna so naprimer pričevanja o nadnaravnem, ki jih za celovito razumevanje človekovega življenja s poplavno ravnico, ni možno obravnavti ločeno od gospodarskih dejavnosti, saj so - kot smo videli zgoraj - soočenja z nadnaravnim potekala sočasno, predvsem pa so bila del tedanje stvarnosti (gl. Mokri svet in nadnaravno). Razvidna je tudi močna simbolna vloga poplavne ravnice, ki je s svojo raznovrstnostjo naravnih in kulturnih oblik, za človeka predstavljala do neke mere neukročen svet, kar se odraža preko pričevanj o zahtevanih pastirskih veščinah in spretnostih. Zlasti na Bregah je razvidna izrazita dvodelnost paše; z nasipi in gostimi mejicami ograjen bližnji pašnik Gmajna (pri vasi) je bil v domeni otrok in star$\operatorname{cev}^{362}$ (Sl. 2). Paša izven teh okvirjev, do $2 \mathrm{~km}$ globoko v poplavni ravnici na relaciji Borovnice-Smrekce-Dolgi prudi-Sopina/Sava, pa je zahtevala starejše in izkušene pastirje in pastirice, še zlasti ob neprilikah, ki so se dogajale ob novem kanalu reke Save (neizkušenost plavalcev) in vodenju živine ob močvirni ledini Globajnk. ${ }^{363}$ Franci Škrabec z Breg zahtevnost in

362 Informator EKC, IFS, VER, SOV, idr.

363 Informator EKC, IFS, VER, SOV, DIN, RVF, idr. pomembnost paše $\mathrm{v}$ poplavni ravnici strne $\mathrm{v}$ šaljivem stavku, ki je nekdaj veljal med tukajšnjimi pastirji: »Na pule srat, v Vrbino scat, pri pastirjih pa maniro držat!«

Sledovi regulacijskih del pod vasjo Drnovo iz različnih obdobij, ki jih je opazoval in beležil že rečni načelnik Franc Avšič (Teppey 1977, 29) in tudi domnevno rimskodobnih, kot za nekatere med njimi domneva Mitja Pergar (ustna informacija), so raziskovalni izzivi, ki nas še čakajo. Obstoj rimskega mesta Neviodunum na območju današnje vasi Drnovo tik nad poplavno ravnico, nas opominja, da je potrebno rimskodobne, kakor tudi sledove drugih obdobij, pričakovati tudi v poplavni ravnici, še zlasti v zaledju Drnovega in Breg (Rutar ı899, II7-II8; Rutar in Premerstein I899, 30; Pergar in Rihter 2008, 60; Rihter 2010, 34; 2015, 69; 2016e) pa tudi Viher (Rihter 2015, 278, Op. 470). Posebno vprašanje v zvezi s tem je, v kakšnem obsegu in stanju so ti ostanki ohranjeni (Mlekuž 2009, 8-9).

\section{Zakjuček}

Raziskava zaledja kmečkih gospodarstev v poplavni ravnici reke Save na Krškem polju na območju vasi Drnovo, Brege, Mrtvice, Vihre ter Gorenjih in Dolenjih Skopic, razkriva pomen človekovega bivanja $\mathrm{v}$ neposredni bližini vodnih virov. Podaja nekatere odgovore na vprašanje, zakaj je človek naseljeval robove poplavnih ravnic in predvsem, kaj je $\mathrm{v}$ njih počel $\mathrm{v}$ prvi polovici 20. stoletja. Hkrati pa nas navaja $\mathrm{k}$ razmisleku o koristnosti teh informacij pri preučevanju preteklosti te in podobnih pokrajin $\mathrm{v}$ različnih zgodovinskih obdobjih.

Zapisali smo pričevanja tistih delov človekovih dejavnosti v konkretnem prostoru poplavne ravnice, ki pogosto ne puščajo materialnih sledi (arheologija) in niso bili pogosta tema zapisovanj (zgodovina). Se pa nanje, kot na povsem samoumnevne pogosto sklicujemo, npr. pri opisih razlogov zakaj je neka naslebina zavzela ta ali on prostor $\mathrm{v}$ nekem prostoru, npr. ob reki ali drugih vodnih površinah. 
Predstavljena pričevanja raziskovalce tega in drugih obrečnih okolj seznanjajo z možnimi in pričakovanimi nabori človekovih dejavnosti v poplavni ravnici, ki so (lahko) pustile sledove v raznovrstnih zapisih, bodisi arheoloških ali drugih, in sicer na točno določenih mestih, tako v poplavni ravnici kakor tudi v naselbinah. Nabor predstavljenih dejavnosti poraja nekatera raziskovalna vprašanja tudi za starejša obdobja v tem in drugih okoljih. Nanje bo možno odgovarjati v prihodnosti z ustrezno izbiro raziskovalnih metod $\mathrm{v}$ okviru posameznih ved. V zvezi z nabiralništvom spomnimo, da vseh dejavnosti ni možno nekritično aplicirati na starejša obdobja, na kar je opozoril že Viko Novak (1957), saj so mnoge med njimi odgovor na že spremenjene gospodraske prakse, kakršna je npr. uvedba hlevske živinoreje (Novak 1957, 20).

Pomembna ugotovitev je, da je človek v poplavni ravnici našel znaten del virov za preživljanje in da so tamkajšnje, na videz drobne individualne dejavnosti, ki so po letu 194I sicer že izgubljale pomen, dejansko predstavljale sestavni in nepogrešljiv del kmečkega življenja. Očitna količinska prevlada podatkov o koriščenju poplavne ravnice, napram količini podatkov o dejavnostih na peleistocenski terasi - ki sicer ni bila predmet pričujoče obravnave, vendar se prevlada kaže kot vzporedni/posredni rezultat te iste raziskave - kaže, da večine teh dejavnosti v suhem, zgornjem polju (pleistocenska terasa), ni bilo možno izvajati. Narava obeh polj je namreč neposredno neprimerljiva. Eden od rezultatov raziskave je torej tudi odgovor na vprašanje kaj sploh je človeku dajalo zgornje polje na pleistocenski terasi, poleg svojih, ne povsod najbolj rodovitnih njiv? Odgovor je skoraj nič iz naslova neagrarnih dejavnosti, kakršne smo spoznali v poplavni ravnici. V poljedelskem oziru je zgornje polje sicer pomenilo žitnico, vendar bi bil vtis, da je bilo zaradi tega tudi pomembnejše od spodnjega polja, napačen. Spodnje polje je namreč dajalo enako dober ali še boljši žitni pridelek ob dejstvu, da je stanovitnejše ob suši. Seveda pa je lahko bilo tudi poplavljeno, vendar praviloma ne $\mathrm{v}$ času največje suše. Gre torej za komplementaren način gospodarjenja, kjer bi bilo izključevanje pomena enega ali drugega dela polja napačno. Zato je pravilneje misliti o komplementarnem gospodarjenju v mokrem in v suhem polju, kjer pa so imele vasi z roba poplavne ravnice neprimerno boljša gospodarska izhodišča, kakor tista, ki so stala drugje. Pomembni sta bili torej obe polji, zgornje in spodnje. $\mathrm{Z}$ izbiro prostora za setev v spodnjem in/ali v zgornjem polju, je lahko človek aktivno vplival na količino pridelka v nepredvidljivih vremenskih in drugih situacijah in s tem tudi na svoj obstoj. Narava obeh polj je $\mathrm{v}$ osnovi zahtevala različna znanja in predpriprave za upravljanje, toda izplen za preživetje je bil boljši. Privlačnost takšne naselitve in takšnega načina gospodarjenja, zato ne moremo razumeti zgolj z bližino vodnih virov kot takih, npr. pitna voda, temveč v pestrosti njihovih pojavnih oblik in spremljevalnih okoliščinah, ki so jih te porajale. V občasno poplavljenih lokah in logovih je človek še pred dobrimi 70 leti tod pridobival številne surovine potrebne $\mathrm{v}$ kmečkem gospodarstvu in gospodinjstvu. Osušene in še živeče mrtvice so naseljevale živali, ki jih ob reguliranem rečnem toku ni bilo več ali pa je imel človek do njih že omejen/otežen dostop, npr. pri ribolovu in drugem koriščenju reke. Podobno velja tudi za rastline, ki so poraščale ti dve območji. Zaradi bogatstva raznovrstnega življenja, ki se ustvarja na stiku kopnega in tedaj deloma še živega in razvejanega vodnega sveta, smo tu zabeležili številna, danes že pozabljena opravila in načine ekstenzivne izrabe (Tab. I), kakršno je naprimer mokro godenje lanu v skopiških mrtvicah. Mnoge predstavljene dejavnosti prejkone, pomenijo zadnje odmeve naravnih danosti, starih navad in znanj pridobljenih s tradicijo življenja ob poplavni ravnici.

Članek posvečam pokojni Uršuli Vodopivec, rojeni Srpčič leta 1926 na Gorenjih Skopicah. 


\section{Summary}

The aim of this inquiry was to collect the last remnants of first-person accounts of farming-related activities in former wetland areas/floodplains located on the right bank of the Sava River in Krško polje (Slovenia). The process of data collection was accompanied by placing the old field's place-names onto exact points in the landscape. In the article, we presented mainly data that can be associated with a particular point in the landscape and represented by a place-name (see Fig. I and Table I). The article is focused on the floodplain area as it was in the first half of the $20^{\text {th }}$ century. During the $19^{\text {th }}$ century, river irrigation works were performed here with the aim to direct the river into a single river flow, i. e. into a channel. Because the works were slower and not as successful as planned, certain areas (including those that are part of this inquiry) in the river's hinterland continued to exist in an almost pre-regulated wetland state. It stayed like that up to the first half of the $20^{\text {th }}$ century. Likewise, some backwaters remained. This enabled the pursuance of low-intensive farming-related activities associated with this type of environment. Some of the people that practiced this kind of husbandry are still alive today and have presented us with the opportunity to get some of the last living accounts of using the damp areas as a part of domestic economy.

Following the deepening of a new river channel the water level was slowly decreasing. By the second half of the $20^{\text {th }}$ century, the area in question was no longer suitable for extensive cultivation and food gathering to a previous extent. A wide variety of activities that were taking place in the first half of the $20^{\text {th }}$ century was documented in the area of the (albeit partially dried) floodplain. They are listed in the table below (Tab. I).

The article also highlights the advantages of living in a border area between two different types of environment: The Holocene Sava terraces and the Upper Pleistocene Sava terrace. The former is characterised by being fertile and moist and the latter by being fertile yet dry. These characteristics conditioned the regional planning of crop cultivation. During drought, the fields located on the Holocene terraces were crucial. Similarly, in the case of floods the Upper Pleistocene terraces were indispensable. We identified three types of fields that are specific for the floodplain area. The first one is Flančisčce (place for breeding plants). It represents the smallest semi-cultivated area and it was usually developed in a wider pastureland area by uprooting shrubs to make place for crop cultivation. Flanišce was not permanently placed - it was in use for up to four months per year and could change location within the pastureland area. Plants (mostly cabbage and fodder beet) were transplanted from flančišce in late June. They were transplanted to the second type of field that was usually selected for this purpose after the barley harvest. These fields were located to up to a $200 \mathrm{~m}$ distance from the settlement and were typically named Drage, Drašca, Vrti and Zevniki. The third type of field forms the smallest example of micro-regional planning of crop cultivation. The best example of this field type can be seen in the Brege village (Fig. 2) with its small house gardens. The Southern part of the village is placed exclusively on the Pleistocene terrace. The Northern part's farmyards extended all the way to the first Holocene terrace below the village. The Southern part of the village had the so called »early gardens «, where the harvest of greens/ crops was earlier than anywhere else, but where the crop was destroyed in case of drought. The Northern part of the village had the so called »late gardens « on lower alluvial fields, where the harvest of greens/crops came later. This area was more resistant to drought.

To conclude: the settlements that were placed above the floodplains in this border area between two different types of environment had undeniable advantages in husbandry in comparison to villages located elsewhere. They could practice not only complementary husbandry but also plenty of other subsidiary activities involving non-agrarian exploitation of natural resources on the area of the Holocene terrace. The types of documented activities in the floodplain are listed in the table below. Every activity in the table is followed by a number for the place-name (represented on Fig. I) where this activity took place. 
Tabela ı: Povezetek glavnih človekovih dejavnosti v poplavni ravnici.

Summary of human main activities in a floodplain.

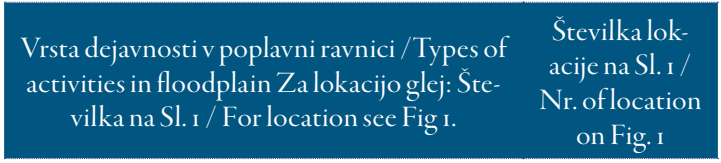

Mokro godenje lanu v mrtvici / Wet retting of flax in backwater

26

Zdravljenje s pijavkami v mrtvici; nabiranje pijavk za domačo uporabo/ Medical treatments with leeches in backwater; collecting $\quad 31,38,43$ leeches for home use

$\begin{array}{lc}\text { Ribolov v mrtvicah / Fishing in backwaters } & \begin{array}{c}26,32,33,37, \\ 39,40\end{array} \\ \begin{array}{l}\text { Ribolov v glavnem rečnem toku / Fishing in } \\ \text { the main river stream }\end{array} & 2,44,5 \mathrm{I} \\ \begin{array}{l}\text { Pranje tkanin ob glavnem rečnem toku / } \\ \text { Washing textiles in the main river stream }\end{array} & 44,50,5 \mathrm{I} \\ \begin{array}{l}\text { Pranje tkanin ob drugih vodnih virih / } \\ \text { Washing textiles in other water sources }\end{array} & 37,49 \\ \begin{array}{l}\text { Spiranje snetljivega žita / Rinsing of blast- } \\ \text { ed cereals }\end{array} & 44,47,50\end{array}$

Kopanje ilovice za domače potrebe / Quarrying clay for domestic use

$29,96,102$

Kopanje zemlje/ Quarrying soil

II, 104

Kopanje peska / Quarrying sand 9, IO, I5, 44, 6I, $73,82,83,108$, IO9, III

Kopanje proda / Quarrying gravel $9,11,39,65,69$, $72,73,104,107$, 109, 110

Nabiranje zdravilnih rastlin in zdravilnih živalskih proizvodov ter rastlinske hrane/ Collecting medicinal plants and animal products and vegetale food

$9,25,48,49,53$, $57,77,78,79$ $82,87,88,89$, $90,91,92,93$, 96, II 4

Nabiranje okrasnih in obrednih rastlin ter živali / Collecting ornamental and ceremo- $\quad 9,12,53,67,96$ nial plants and animals

Rastline za domačo izdelavo orodij in pripomočkov / Plants for home-made tools and accessories

I, 17,30, 53, 55, $56,57,97$

\section{Vrsta dejavnosti v poplavni ravnici / Types of activities in floodplain Za lokacijo glej: Šte- vilka na Sl. I / For location see Fig I.} on Fig. I

Flančišča - nestalni gojitveni vrtovi /

Flančišča - inconstant places for cultivation $\quad 7,8,9$ IO, I2 of plants

Pridobivanje lesa za gradnjo in za druge domače potrebe / Acquisition of construction wood and wood for domestic use

I, 28, 30, 53, 56, 78,79

Drevesa kot mejniki / Trees as a boundary markers or landmarks

IO, $48,95, \mathrm{IOI}$

Nabiranje plodov plodonosnega grmičevja / Gathering of fruit from fruitful shrubs

$5,33,76,77$, 78,79

Lomljenje ledu za ledenice / Acquisition of ice for icehouses

52

Izviri - potočki / Springs - brooks

$29,33,37,38,40$

$49,52,55,56$,

92,93 ,

Paša živine in konj / Pasture of cattle and $9,26,27,28,38$, $40,42,49,53$, horses

$54,56,57,78$, $79,86,96,113$

Paša gosi / Geese pasture

$21,22,52,57$ 58,61

Paša avtohtone krškopoljske pasme prašičev / Pasture of the autochthonous »Krško-polje-type $\ll$ of pigs

$9,29,57,61$

Nabiranje hrane za prašiče / Gathering of fodder for pigs

$9,17,73$

Plavanje, drsanje na ledu in druge otroške igre / Swimming, ice skating and other childhood games

$9,32,38,40,5 \mathrm{I}$, $58,95,111$

Prostori kurjenja (poletnih) kresov / Places for (midsummer) bonfires

$9,88,94,95$

Improvizirane mokre jame ob poteh za predelavo rastlinskih odpadkov v gnojila/ Improvised damp pits along the paths for pro-

II, 53 cessing of vegetal waste into manure

\section{Zahvale}

Za podatke o nekdanjem življenju s poplavno ravnico hvala vsem pripovedovalcem. Za pomoč pri opisih in iskanju rastlin v naravi ter za mož- 
nost ogleda originalnih predmetov hvala Elki Grilc, Veri Jurečič, Ivanki Kobal, Branku Srpčiču, Franciju Škrabcu in Sonji Budna. Za izdatno pomoč pri lociranju nekaterih toponimov hvala st. Francu Škofljancu, Marjanu Barbiču, Jožetu Stoparju, Vinku Škofljancu, Jožetu Račečiču - Šavarču, Janku Teršeliču, Marjanu Horženu, Anici Zahrastnik, Jožetu Gramcu, Mirku Račiču, Dušanu Lukiču, Tomažu Margetiču, Petru Račiču, Janezu in Francu Lopatiču, Slavku Žičkarju, Alojzu Golobu, Alojzu Pircu, Ani Žabkar, Ani Strle in Jožetu Urbanču. Hvala Špeli Pungaršek (Prirodoslovni muzej Slovenije, Kustodiat za botaniko) za določanje nekaterih rastlinskih vrst na podlagi ljudskih imen in opisov ter Tomiju Trilarju in Tei Knapič (Prirodoslovni muzej Slovenije, Kustodiat za nevretenčarje) za vsa dognanja v zvezi s pajkom Atypus in gosenic. Hvala Mitji Pergarju (ZVKDS, OE Ljubljana) za pogovore o poplavni ravnici in njenem izgledu v arheoloških dobah. Za kritično branje, za koristne pripombe ali za nasvete hvala Anji Mlakar, Mihi Miheliču, ZVKDS (CPA) in Timoteju Knificu (NMS). Z Inštituta za arheologijo ZRC-SAZU hvala Maji Andrič, Andreju Pleterskemu, Benjaminu Štularju, Tjaši Tolar in Borutu Toškanu.

\section{Viri in literatura}

Bavec, U. 2006. »Arheološko najdišče Gorenje Skopice - Pečina. «Varstvo spomenikov 42 (Poročila): 44-45.

Bavec, U. 2009. »Rimljani ob veliki reki poskus opisa rimske poselitve Posavja v času od I. do 4. stoletja. «V Ukročena lepotica: Sava in njene zgodbe, uredil J. Petrnel, 5I-76. Sevnica: Javni zavod za kulturo, šport, turizem in mladinske dejavnosti.

Britovšek, M. 1964. Razkroj fevdalne agrarne strukture na Kranjskem. Ljubljana: Slovenska matica.

Bras, L. 1970. Pletarstvo na Slovenskem. Vodnik po razstavi. Ljubljana: Slovenski etnografski muzej.
Brečko, B. 2008. Živi svet Vrbine. Brežice: Agencija za radioaktivne odpadke, Lokalno partnerstvo.

Brenčič, P., et al. 2003. Krško: stoletje na razglednicah. Krško: Založba Neviodunum.

Brown, A. G. 2001. Alluvial geoarchaeology: floodplain archaeology and environmental change. Cambridge manuals in archaeology. Cambridge : University press.

B. T. 2or 4. »Jubilanti. «Lovec, XCVII, September 2014: 464.

Costa, H. 1848. »Reiseerinnerungen aus Krain. Druck der Eger'schen GubernialBuchdruckerei. « Laibach I848: 103.

C. -Hoffmann, R. 1996. »Economic Development and Aquatic Ecosystems in Medieval Europe. «The American Historical Review IOI (3): 631-669.

D. Š. 1930. »Življenje in tegobe Krškega polja. «Jutro, XII (295) (2I. I2. 1930): II.

Evans, J. G. 2003. Environmental archaeology and the social order. London: Routledge.

Gugič, G. 2006. Bilten Parka prirode Lonjsko polje Vol. 8/No. I/2. Krapje: Javna ustanova Park prirode Lonjsko polje.

Hoffmann, R. 2008. Medieval Europeans and their Aquatic Ecosystems. V Beiträge zum Göttinger Umwelthistorischen Kolloquium 2007-2008, ur. B. Herrmann, 45-64. Göttingen: Universitätsverlag.

Hudoklin, A. 2008. »Naravovarstveni pogled na Vrbino. « Živi svet Vrbine, i-iii. Brežice: Agencija za radioaktivne odpadke, Lokalno partnerstvo.

Hudoklin, A. 1993. »Naravovarstveni pomen habitatov v spodnjem Posavju. « Acrocephalus (Spodnje Posavje) I4(6I): I77185 .

Vogrin, M. in A. Hudoklin. 1993. »Ptice ob spodnjem toku reke Save. «Acrocephalus 6I(1993): 19I-200.

Hrobat, K. 2009. »Folklora v vlogi označevanja vaških mej kot prostorskih vrzeli v onostranstvo: primer Rodika. « Studia mythologica Slavica XII: 207-222. 
Klenovšek, D. 2009. »Kvaka, a leti - kvakač. « Svetptic 15(2): 22-23.

Klenovšek, D. 200I. »Travniki ob Savi so še bogati. « Dolenjski list 52(27) (2006) (05. 07. 200I): II.

Klenovšek, D. 1999. »Ptice ob reki Savi. « Proteus 62(I) (sep. 1999): 30-34.

Kuhar, B. 1972. Odmirajoči stari svet vasi: poljudno znanstvena razprava. Ljubljana: Prešernova družba.

Koropec, J. 1977. »Krško v obdobju velikih slovenskih kmečkih vstaj. « Krško skozi čas: 1477-1977. Zbornik ob soo-letnici mesta, ur. L. Smrekar, 45-6o. Krško: Skupščina občine Krško.

Kronberg, H. 1839. »Die Schiffahre Sava in Krain. « Carniola 92(15. 3. I839): 366-367.

Lovrenčak, F. 1980. »Prst in rastje poplavnega sveta ob Krki. « Geografski vestnik: Geografske značilnosti poplavnih območij ob Krkipod Otočcem XX (1980) (198I): 95208.

Makarovič, M. 1960. »Delo etnografskega muzeja v Ljubljani v letih 1957-1959. « Slovenski etnograf $30(\mathrm{I}): 20 \mathrm{I}-207$.

Makarovič, G. 1991. »Prehrana v 19. stoletju na Slovenskem. « Slovenski etnograf XXXIIIXXXIV (1988-1990): 127-206.

Martinčič et al. 1999. Mala flora Slovenije: ključ za določanje praprotnic in semenk (3., dopolnjena in spremenjena izd. ). Ljubljana: Tehniška založba Slovenije.

Mencej, M. 2006. Coprnice so me nosile. Raziskava vaškega čarovništva v vzhodni Sloveniji na prelomu tisočletja. Ljubljana: Filozofska fakulteta, Oddelek za etnologijo in kulturno antropologijo.

Mlakar, V. 2015. Rastlina je sveta, od korenin do cveta. Tradicionalno znanje o rastlinskem svetu na Slovenskem. Ljubljana: V. Mlakar.

Mlekuž, D. 2009. Poplavne ravnice v novi luči : LiDAR in tafonomija aluvialnib krajin. Arheo (26): 7-22.

Mlinarič, J. 1977. »Krško in njegova gospoščina v srednjem veku. « Krško skozi čas: 14771977. Zbornik ob soo-letnici mesta, ur. L.
Smrekar, 25-44. Krško: Skupščina občine Krško.

Novak, V. 1947. Ljudska prehrana v Prekmurju. Etnografska študija. Ljubljana: Slovenski knjižni zavod.

Novak, V. 1957. »Vprašanje nabiralništva pri Slovencih. « Slovenski etnograf X (1957): 19-28.

N. N. 1893. »Gospodarske stvari: Pauliš Baraczko. «Dolenjske novice (I. 5. I893), IX (9): 69-70. www. dlib. si

N. N. 190I. »Pletarska šola. « Slovenski gospodar (28. II. I90I), 35 (48): 3. www. dlib. si

N. N. I893. »Domače vesti (Iz Krškega). « Dolenjske novice (I5. I. I893), IX (2): 13-I4. www. dlib. si

Papež, A. 2010. Uporaba divje rastočih rastlin $v$ prehrani. Neobjavljeno diplomsko delo, Oddelek za biologijo. Ljubljana: Biotehnična fakulteta Univerze v Ljubljani.

V 1 (1) gar, M. in Rihter, J. 2008. »Drnovo-Žabjek. 60. « Varstvo spomenikov 44: 60.

Pergar, M. in Rihter, J. 2008. »Vihre -Brežnice. 60. « Varstvo spomenikov 44: 297.

Plemel, V. I862. »Beitrage zur Flora Krain's. «Drittes Jabresheft des Vereines des krainischen Landes-Museums, $120-164$.

Pintar, L. I895. »Slovarski in besedoslovni paberki. « Letopis slovesnke matice, ur. A. Bartel, I-52. Ljubljana: Založila in izdala matica slovenska.

Pirc, F. 20I4. »Dvorec Grossdorf Velika vas. «Velika in Gorenja vas, Leskovec pri Krškem, ur. J. Spahalić, 163-169. Velika vas: Fotografika.

Počkar, I. (ur) 1998. Iz časov ječmenove kave: življenjepisi Štajercev in Kranjcev ob sotočju Krke, Save in Sotle. Novo mesto: Tiskarna Novo mesto.

Počkar, I. 2000. »Opekarstvo in opekarji v Brežicah. «Rast XI, 6(72), XI: 525-536.

Počkar, I. 200Ia. »Opekarstvo in opekarji v Brežicah. (Nadaljevanje iz prejšnje številke). Rast XII, I(73): 33-49. 
Počkar, I. 20orb. »Od svinje do votivnega prašička. « Rast XII, I(73): 576-589.

Počkar, I., 2009. »Kólnarji - lovilci in nabiralci premoga v Savi pri Brežicah, po toku navzgor in navzdol. « Gospa, če ni dobro, ni treba nič plačat: Brežice, trgovsko mesto (Brežiške študije; 3), ur. J. Škofljanec, 319387. Krško: Zavod Neviodunum.

Radinja, D. et al. 1976. »Geografske značilnosti poplavnega področja ob Pšati : I. del dolgoročne raziskovalne naloge »Geografija poplavnih področij na Slovenskem «, ki jo je prevzel Inštitut za geografijo SAZU. « Acta geographica I5: II-60.

Ravbar, M. 2008. »K nekdanjemu sijaju: letališče Cerklje ob Krki. «Revija obramba 40(6) (jul. 2008): 48-5I.

Rihter, J. 2006. \O prežitkih čarovništva na Drnovem in v okolici. «Profil: revija študentskega arheološkega društva, Študijsko leto 2005/2006, 3: 19-22.

Rihter, J. 2007. Vodic po kranjski vrbini, 25. september 2007. (Neobjavljeno gradivo, hrani ZVKDS OE Ljubljana Dopolnjena verzija).

Rihter, J. 2008. \O strahovih na Krškem polju - dve ledini Beli breg in Gauge. « Profil: revija študentskega arheološkega društva, Śtudijsko leto 2007/2008, 5: 2I-23.

Rihter, J. 2010. »Antropogene aktivnosti na holocenskih terasah južno od reke Save v zaledju Gorenjih in Dolenjih Skopic na Krškem polju in izbrani odstavki iz knjige spominov Uršule Vodopivec. « Profil: revija študentskega arheološkega društva, Študijsko leto 2009/2010, 6: 24-37.

Rihter, J. 20II. »Odnos do arheološke dediščine na Drnovem pri Krškem (Neviodunum) skozi časopisje od sredine 19. do sredine 20. stoletja. «Profil: revija študentskega arheološkega društva, Študijsko leto 2010/201I, 3-15.

Rihter, J. 20I 4. »Drobci iz preteklosti Velike vasi in Gorenje vasi v Leskovcu pri Krškem. «Velika in Gorenja vas, Leskovec pri Krškem, ur. J. Spahalić, 9-87. Velika vas: Fotografika.

Rihter, J. 2015. Drnovo pri Krškem: retrogradna analiza katastra, ustno izročilo, arheološka topografija in mitična pokrajina.

Neobjavljeno diplomsko delo. Oddelek za arheologijo. Ljubljana: Filozofska fakulteta Univerze v Ljubljani.

Rihter, J. 20I6a. »Gorenje/Dolenje cesarsko - ostanki kamnitih struktur iz časa regulacije reke Save. «Varstvo spomenikov 50-51: 58-59.

Rihter, J. 2016b. »Mrtvice in Vihre - Petrova škarpa (del obsavske vlečne poti med letoma 1853 in 1862 ). «Varstvo spomenikov 50-51: 15I-I52.

Rihter, J. 2016c. »Vihre - Turški brod pri Skopiškem zalivu. «Varstvo spomenikov 50-5I: 24I-242.

Rihter, J. 20ı6d. »Avstro-ogrsko vojaško strelišče topničarjev in vadbeni poligon letalskih sil JA/JLA. «Varstvo spomenikov 50-51: $247-249$.

Rihter, J. 20I6e. »Pliš-Zaroman. «Varstvo spomenikov 50-51: 249-250.

Rihter, J. 2017. »Območje jugovzhodne neviodunske vpadnice v ustnem izročilu. « Studia mythologica Slavica XX: 55-8I.

Ripšl, D. F. 2007. »Kronika fare Videm. « Med najlepše kraje slovenskega Štajerja šteje se župnija Videm : zbornik ob 85o-letnici prve pisne omembe pražupnije Videm ob Savi, ur. A. Črnelič Krošelj in M. Makarovič, I38I7I. Krško: Valvasorjev raziskovalni center Krško.

Rohrman, V. I899. »Prašičje pleme na Dolenjskem. « Kmetovalec: gospodarski list s podobami I6(2) (3I. OI. I899): 9-II.

Rutar, S. in A. Premerstein. 1899. Römische Strassen und Befestigungen in Krain mit Karten und Facsimilien. Wien: K. K. Central-Commission zur Erforschung und Erhaltung der kunst- und historischen Denkamale. 
Rutar, S. I899. »Rimska cesta $\gg$ AquileiaSiscia«. «Izvestja Muzejskega društva za Kranjsko 9(4): II3-II9.

Seručnik, M. 2009. »Reambulančni kataster za Kranjsko. « Kronika: časopis za slovensko krajevno zgodovino 57(3): 49I-504.

Snoj, M. 2009. Etimološki slovar slovenskih zemljepisnih imen. Ljubljana: Modrijan, Založba ZRC.

Sosič, B. 2000. »Gradivo o ljudski medicini v zapisih terenskih ekip slovenskega etnografskega muzeja. «Etnolog: glasnik Slovenskega etnografskega muzeja 10: 213254.

Stritar, A. 1990. Krajina, krajinski sistemi; Raba in varstvo tal v Sloveniji. Ljubljana: Partizanska knjiga.

Stritar, A. 1977. »Tla in podobe krajin v spodnjesavskem predelu Slovenije. « Lado Smrekar (urednik), Krško skozi čas: I4771977. Zbornik ob soo-letnici mesta, ur. L. Smrekar, 627-638. Krško: Skupščina občine Krško.

Smole, M. 1980. Graščina Šrajbarski turn. Ljubljana: Arhiv SR Slovenije.

Šebek, Ž. 2009. Krško - življenje z reko Savo. Krško: Založba Neviodunum.

Šribar, L. 20I8. »Kmetijsko zadružništvo. Zadružno gospodarjenje v Leskovcu pri Krškem na področju agrokulture. «Leskovec pri Krškem skozi čas, ur. J. Spahalić, 99-I47. Leskovec pri Krškem: Krajevna skupnost.

Šubic, P. 2018. Krškopoljski prašič bo glavna zvezda nove turistično-kulinarične ponudbe v Posavju (19. or. 2018). Dostopno: https:// agrobiznis. finance. si $/ 8863778$ ?cctest $\&$ (10. OI. 2019).

Teppey, J. 1971. »Dolga sobota kmetice z Drnovega. « Dolenjski list XXII(47) (II30), (25. II. 1971): 22.

Teppey, J. 1977. »Prijateljstvo z reko. « Dolenjski list XXVIII (44)(I475) (Iо. II. 1977): 29.
Umek, E. 1986. »Plovba po Savi in Ljubljanici v i8. stoletju. « Zgodovinski časopis $40(3)$, 233-286.

Umek, E. 1996. »Promet po Savi in mitnina v Krškem. « Gestrinov zbornik, 27I-278. Ljubljana: ZRC SAZU.

Valenčič, V. 1965. »Iz zgodovine naših gozdov. Dolenjski gozdovi v terezijanskem katastru. « Gozdraski vestnik XXIII: I8I192.

Valvasor, J. V. 2010. Slava vojvodine Kranjske, II. knjiga: Kratka topografija. Ljubljana: Zavod Dežela Kranjska.

Vrhovec, I. I895. »Čolnarji in brodniki na • Ljubljanici in Savi. «Slovenska matica IX: 97-I4I.

Valenčič, V. 1970. »Vrste zemljišč. « Gospodarska in družbena zgodovina Slovencev: Zgodovina agrarnih panog. Zv. I, Agrarno gospodarstvo, I3I-I 48. Ljubljana: Državna založba Slovenije.

Verbič, T. in B. Berič. 1993. »Struge reke Save • med Krškim in Brežicami v 19. stoletju. « Proteus 56(1993-1994): 327-333.

Verbič, T. 2004. »Stratigrafija kvartarja in neotektonika vzhodnega dela Krške kotline. I. del: Stratigrafija. «Razprave 45(3)(2004): 17I-225.

Šalehar, A. 2015. Krškopoljski prašič: iskanje ostankov, ohranjanje in osvežitev pasme v letih 19go-2003. Slovenj Gradec : Kmetijska založba.

Verbič, T. 2008. Kvartarni sedimenti, stratigrafija in neotektonika vzhodnega dela Krške kotline. Neobjavljena doktorska disertacija, Oddelek za geologijo.

Ljubljana: Naravoslovnotehniška fakulteta Univerze v Ljubljani.

Vrhovec, I. I895. »Čolnarji in brodniki na Ljubljanici in Savi. « Slovenska matica IX: 97-I 4I.

Vodopivec, U. 2008. Knjiga spominov (za Jerneja). Rokopis. Privatni arhiv. Neobjavljeno gradivo.

Wright, S. in S. L. Goodacre. 2012. Evidence for antimicrobial activity associated with 
common house spider silk. BMC Research Notes 5(326): I-6.

Zadravec, J. 1985. »Fragmenti iz ljudske medicine v severovzhodni Sloveniji. « Zbornik za zgodovino naravoslovja in tehnike 8, ur. F. Dominko, str. 127-136. Ljubljana: Slovenska matica Ljubljana.

Zadravec, J. 2000. »Ljudsko zdravilstvo v Prekmurju. « Etnolog: Glasnik Slovenskega etnografskega muzeja 10: 45-62.

Zakšek, J. 20r2. 》Milena Kuhar z Malenc, ki je ugledala luč sveta prvega januarja 1928. « Kostanjeviške novice. Glasilo občine Kostanjevica na Krki, marec(54): 29-33.

Zelko, I. 1985. »Prekmurska ledinska imena -in primerjava s Panonskoslovenskimi imeni. « Slavistična revija 33 (4) (oktoberdecember): 459-465.

\section{Leksikoni, spletne zbirke in slovarji}

KLDB 1937: Krajeuni leksikon dravske banovine: krajevni repertorij $z$ uradnimi, topografskimi, zemljepisnimi, zgodovinskimi, kulturnimi, gospodarskimi in tujskoprometnimi podatki vseh krajev dravske banovine. Ljubljana: Uprava Krajevnega leksikona dravske banovine.

Pleteršnik, M. Slovensko-nemški slovar: Dostop: www. fran. si. (4. 7. 2019).

Kramarič V. Fototeka SEM. 604 Fo037206. Drnovo pri Krškem. Med leti 1928 in 1947 (https://www. etno-muzej. si).

\section{Arhivsko gradivo}

SI ARS, AS 176, Franciscejski kataster za Kranjsko, k. o. Leskovec pri Krškem; mapni list VII, N o87(I824), abecedni seznam posestnikov $\mathrm{N} \circ 87$ PUA (24. 4. I825); zapisnik zemljiških parcel, $\mathrm{N} \circ 87 \mathrm{PS}$ (april I825), cenilni elaborat, NO 87PZ (26. 3. 1834 ).

SI ARS, AS 176, Franciscejski kataster za Kranjsko, k. o. Krška vas: mape (I824), zapisnik zemljiških parcel, $\mathrm{N}_{165}$ PS (9. 4. I825); abecedni seznam posestnikov, $\mathrm{N}$
I65 PUA (9. 4. 1825) in cenilni elaborat, $\mathrm{N}$ I65PZ (28. 4. 1833).

SI ARS, AS 176, Franciscejski kataster za Kranjsko, k. o. Drnovo; mapni listi (1824); abecedni seznam posestnikov, $\mathrm{N} 033$ PUA (I0. 4. I825); zapisnik zemljiških parcel, N 033 PS (10. 4. 1825), cenilni elaborat, NO ${ }_{33} \mathrm{PZ}$ (20. januar I833). 



\title{
»Prekrasni arhitektov sen o našem Pantheonu « - Plečnikovi neuresničeni načrt za slavnostno pokopališče zaslužnih Slovencev
}

\author{
Franci Lazarini, Univerza v Mariboru, Filozofska fakulteta, Maribor in ZRC SAZU, \\ Umetnostnozgodovinski inštitut Franceta Steleta, Ljubljana
}

Prispevek obravnava neuresničene načrte Jožeta Plečnika za »Častno pokopališče zaslužnih Slovencev«. V sklopu urbanističnega urejanja Bežigrada, severnega dela Ljubljane, se je arhitekt posvetil tudi ureditvi območja opuščenega pokopališča pri sv. Krištofu, kjer bi poleg povečave tamkajšnje cerkve in gradnje novega monumentalnega sakralnega objekta (Hrama slave) uredili tudi spominski park, ki bi kot Slovenski panteon ključno pripomogel h kreiranju zgodovinskega spomina in spodbujanju narodne zavesti. Projekt zaradi drugačnih želja lastnika zemljišča, ljubljanske škofije, ni bil uresničen, njegov edini ostanek je spominski park Navje, ki že zaradi majhnih dimenzij nikoli ni igral vloge, kot bi jo prvotna zamisel.

Ključne besede: Jože Plečnik, Ljubljana, Navje, nacionalni panteon, zgodovinski spomin

The article discusses the unexecuted plans for "Honorary cemetery of important Slovenians", designed by architect Jože Plečnik. In the frame of urban planning of Bežigrad, northern part of Ljubljana, the architect also dealt with the territory of the abandoned St. Christopher cemetery, where the enlargement of St. Christopher church, new monumental church (Hall of Fame) as well as memorial park has been planned. The latter should become a Slovenian Pantheon and as such play an important role in creating historical memory and promoting national consciousness. Due to the different wishes of the owner of the area, Diocese of Ljubljana, the project was never executed, its only remaining is Navje memorial park, which has, due to much smaller dimension, never played the same role as Plečnik's original idea would.

Key words: Jože Plečnik, Ljubljana, Navje, national pantheon, historical memory

$\mathrm{D}$ vajseta in trideseta leta 20 . stoletja predstavljajo obdobje, ko je Ljubljana precej spremenila svoj videz. K temu je poleg precejšnjega povečanja prebivalstva prispevala težnja, da bi prestolnica Slovencev v novi državi južnih Slovanov dobila vse za narod pomembne kulturne ustanove in njim pripadajoče objekte, pa tudi, da bi izgubila videz avstrijskega provincialnega mesta, pri čemer je ključno vlogo igral arhitekt Jože Plečnik (I872-1957), s svojimi izjemnimi arhitekturnimi in urbanističnimi rešitvami. Pričujoči prispevek obravnava njegove pretežno neuresničene načrte za ureditev območja opuščenega pokopališča pri svetem Krištofu za Bežigradom. Medtem ko so se starejše študije ukvarjale zlasti z urbanističnim pomenom projektov (Prelovšek 1992, 276; Krečič 1992, 21924; Stabenow 1996, 62-66; Prelovšek 2017, 32829), monumentalno cerkvijo (t. i. Hramom slave) (Prelovšek 1992, 306-7; Prelovšek 2017, 365-66) ali povečavo nekdanje pokopališke cerkve sv. Krištofa (Krečič 1992, 257-6I; Valena 2013, 348), pa se pričujoči prispevek osredotoča na neuresničene načrte za ureditev slavnostnega pokopališča 


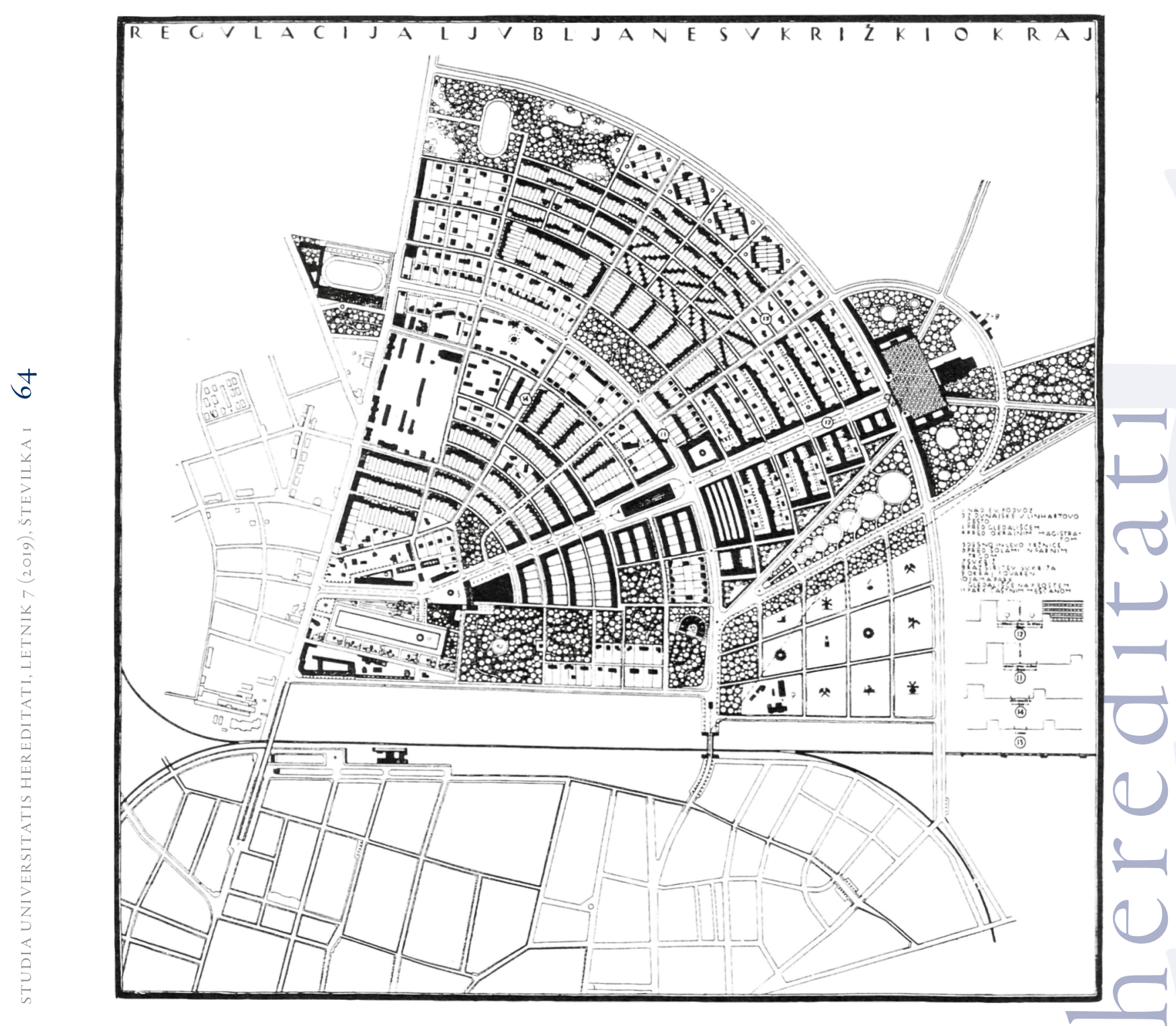

Slika i: Jože Plečnik: Regulacijski načrt za Svetokrižki okraj, Ljubljana, 1928 (po: Plečnik 1929).

zaslužnih Slovencev, $s$ katerim bi mesto dobilo svojevrsten nacionalni spomenik, ki bi imel pomembno vlogo pri oblikovanju narodne zavesti in spodbujanju domoljubja.

Bežigrad, severni del Ljubljane, je v obravnavanem času izmed vseh mestnih predelov doživel največji gradbeni razcvet. Medtem ko je prvi urbanistični načrt za Bežigrad že leta 1898 izdelal Maks Fabiani (1865-1962), ki je ta del mes- ta zasnoval skladno $s$ sodobnimi urbanističnimi smernicami, s pravokotno se sekajočo ulično mrežo in prestavitvijo železniške proge, ki bi omogočila nadaljevanje glavnih cest iz centra (Fabiani I899, 5-12; Pozzetto 1983, 37-38; Krečič 1992, 22I-22; Pozzetto 1997, IIO-II; Mihelič 2008, 9), pa je do večjih gradbenih posegov prišlo šele po prvi svetovni vojni, pri čemer se je Fabianijev načrt, uradno odobren I90I, izkazal za neiz- 
vedljivega, ker ni upošteval obstoječih parcelnih mej, zaradi česar bi bile potrebne obsežne komasacije (Lenarčič 1940, 36, 41; Krečič 1992, 220). Problematiko je mestna oblast leta 1918 formalno rešila z odločitvijo o izdelavi regulacijskega načrta, ki je upošteval dejanske parcelne meje, ni pa se oziral na prometne, gospodarske in estetske vidike. Prav njegova pretirana liberalnost je povzročila nekaj daljnosežnih napak v zasnovi Bežigrada, načrt pa so že pred sredino dvajsetih let zavrgli (Lenarčič 1940, 42-44). Do pomembnejšega premika je prišlo šele 1924 , ko je vodja mestnega gradbenega urada inž. Matko Prelovšek (I876I955) Plečnika povabil k pripravi novega urbanističnega načrta za severni del mesta. ${ }^{.}$Tako je leta 1928 arhitekt izdelal regulacijski načrt za Svetokrižki okraj (kot je po cerkvi sv. Križa pred novim pokopališčem, Bežigrad poimenoval Plečnik), katerega izhodišče je predstavljala četrtina kroga, enega ključnih elementov pa osrednja avenija, ki bi povezovala novo pokopališče pri svetem Križu (sedaj Žale) z opuščenim pokopališčem in cerkvijo sv. Krištofa in ob kateri si je mojster zamislil javne stavbe (občinska hiša oz. okrajni magistrat, šole, gledališče) (Plečnik 1929, 91; Prelovšek 1992, 274-77, Krečič 1992, 222-23; Stabenow 1996, 62-66; Prelovšek 2017, 326-30). S tem je bil postavljen temelj za Plečnikova prihodnja razmišljanja o ureditvi območja starega pokopališča, med drugim $\mathrm{z}$ vzpostavitvijo parka slavnih, ki bi hkrati služil tudi kot pomemben urbanistični element, saj bi pomagal usmerjati potek nove trase Linhartove ceste.

Ena prvih stavb na območju današnjega Bežigrada je bila srednjeveška, v 17. in I8. stoletju v več fazah barokizirana, cerkev sv. Krištofa, ki je bila podružnica šempetrske župnije. ${ }^{2}$ Njen pomen se je precej povečal leta 1779, ko so okoli nje uredili osrednje ljubljansko pokopališče (Bajuk 1930, 6; Steska 1940, 31; Lavrič 20I2, 19). ${ }^{3}$ Kot

\footnotetext{
Muzej in galerije mesta Ljubljane, Plečnikova zbirka, Pismo Matka Prelovška Plečniku, 19.4. 1924.

O zgodovini, arhitekturi in opremi cerkve sv. Krištofa: Lavrič 20I2, $7^{-22}$.

Slednje je nadomestilo srednjeveška ljubljanska pokopališča, zlasti tisti ob nekdanjem frančiškanskem samostanu (na območju današnjega Vodnikovega trga) in ob cerkvi sv. Petra.
}

posledica naraščajočega mesta je bila na prehodu 19. v 20. stoletje sprožena pobuda za gradnjo novega pokopališča pri svetem Križu, kasnejših Žal, za katerega je načrte izdelal dunajski arhitekt Ferdinand Trummler, ki je bilo odprto leta 1906 (Bajuk 1930, 17; Steska 1940, 31; Piškur 2004, 7-8; Sapač 2015, 483). S tem so postopoma prenehali pokopavati za Bežigradom, nadaljnja usoda prostora, ki je predstavljalo versko, pietetno in siceršnje središče tega dela Ljubljane, pa je ostala nejasna. Še zlasti v sredini dvajsetih let, ko so dokončno prenehali s pokopi na starem pokopališču, je prostor postal žrtev različnih vandalizmov, pogoste pa so bile tudi kraje kovinskih nagrobnih križev (Piškur in Žitko 1997, 9).

Plečnik se je z območjem pokopališča pri svetem Krištofu prvič ukvarjal že leta 1919, ko je ljubljanskemu škofu dr. Antonu Bonaventuri Jegliču (1850-1937) predlagal povečavo Krištofove cerkve (Prelovšek 1992, 306; Hrausky et al. 1996, 187; Valena 2013, 249, op. 32; Prelovšek $2017,365) .{ }^{4}$ Intenzivneje pa se je področju posvetil po $1924 \mathrm{~V}$ sklopu izdelave regulacijskega načrta. V tem okviru je leta 1927 Matku Prelovšku predlagal, da bi na mestu opuščenega grobišča uredili pokopališče nedolžnih, po potrebi pa tudi nezakonskih otrok ter pokopališče »slavnih mož Slovenije«, s čimer bi ublažili »ostrašujoči učinek navadnega britofa« (Gostiša 1986, II6). ${ }^{5}$ Medtem, ko se je prvi ideji, zaradi nerazumevanja javnosti, kmalu odrekel, čeprav jo mimogrede še navede v obrazložitvi regulacijskega načrta, pa je spominski park ves čas ostal sestavni del arhitektovih razmišljanj, ki ga je z zapisom »park častnih meščanov« vključil tudi v sam regulacijski načrt (Plečnik 1929, 9I). S tem predlogom se je navezal na starejše težnje različnih društev in posameznikov, ki so se zavzemali za ureditev pokopališča zaslužnih Slovencev na novem pokopališču pri svetem Križu in za skrb za pomembne grobove pri svetem Krištofu (Piškur in Žitko 1997, 8). Po objavi Plečnikovega regulacijskega načrta se je povečalo zanima-

4 Načrt za povečavo cerkve sv. Krištofa iz leta 1919 je reproduciran v: Valena 2013,248.

Plečnikovo pismo Matku Prelovšku, 6. I. 1927, je v lasti Damjana Prelovška. Prepis je objavljen v: Gostiša 1986, 116. 
nje za usodo starega pokopališča, tako je na primer $\mathrm{v}$ strahu pred njegovo odstranitvijo klasični filolog in glasbenik Marko Bajuk (I882-196I) izdal popis nagrobnikov pomembnih osebnosti na obeh osrednjih ljubljanskih pokopališčih (Bajuk I930); slednji je predstavljal eno od izhodišč za kasnejši izbor nagrobnikov v spominskem parku (Piškur in Žitko 1997, 9).

Možnosti za realizacijo Plečnikovih načrtov za park slavnih so se pokazale v začetku tridesetih let, ko se je poleg želje po ureditvi središča Bežigrada pojavila tudi potreba po večji cerkvi, saj je bila pri sv. Krištofu načrtovana ustanovitev župnije, kar se je zgodilo I. januarja 1934 (Zakrajšek I940, 66). Plečniku se je tedaj ponudila izjemna priložnost, $v$ eni potezi rešiti oba navedena problema, hkrati pa prispevati pomemben spomenik slovenski preteklosti in kulturi. Slednji bi imel ključno vlogo pri krepitvi narodne zavesti, pa tudi pri generiranju narodovega zgodovinskega spomina. Skladno z ambicioznimi načrti, izdelanimi leta 1932 (Hrausky et al. 1996, I84), ki jih je javnosti v reviji Dom in svet leto dni kasneje predstavil umetnostni zgodovinar dr. France Stele (1886-1972), bi novo ureditev dobilo celotno območje opuščenega pokopališča, le njegov severozahodni vogal bi »žrtvovali $\ll$ za novo Linhartovo cesto, $v$ severovzhodnem pa zgradili šolsko poslopje (Stele 1933, 65; Stele 1940, 45-46). Ker zaradi finančnih razlogov ni bilo verjetno, da bi Bežigrad v kratkem dobil novo svetišče, je Plečnik izdelal načrte za prizidek h Krištofovi cerkvi, kasnejšo cerkev sv. Cirila in Metoda, ki je bila ena najizvirnejših povečav sakralnih stavb pri nas. Zasnovana je bila tako, da bi, ko bo nekoč zgrajena nova cerkev, stara lahko prevzela vlogo župnijske dvorane (Stele 1933, 65-66; Stele I940, 46, 48; Prelovšek 1992, 307; Valena 2013, 248; Prelovšek 2017, 365). Med povečano župnijsko cerkvijo in novo stanovanjsko hišo severno od nje, bi ležal tudi vhod v celoten kompleks. Prizidek h Krištofovi cerkvi bi s svojo neobičajno lego usmerjal z drevoredoma obdano glavno pot, ki bi se iztekla v veliki cerkvi, posvečeni sv. Cirilu in Metodu, sicer pa imenovani Hram slave, ki bila zgrajena vzhodno ob obstoječe, ko bi zadoš- čala finančna sredstva. Izjemno monumentalno stavbo, za katero je načrte izrisal arhitektov študent Edvard Ravnikar (1907-1993), po drugi svetovni vojni eden vodilnih slovenskih arhitektov, bi poudarjal visok ploščat koničast zvonik (Plečnik 1937, s. p.; Gollmann 2005, 33), ${ }^{6}$ ki podobno kot nekateri drugi detajli spominja na $\mathrm{v}$ tistem času dograjeno Plečnikovo cerkev Srca Jezusovega v Pragi (zgrajena 1928-1932) (Prelovšek 1992, 307; Prelovšek 2017, 365). ${ }^{7}$ Hram slave bi na obeh straneh obdajal drevored, ki bi obiskovalce pripeljal do preostanka pokopališča, preurejenega v spominski park. Arhitektu so izhodišče za njegovo načrtovanje predstavljale klasicistične arkade na vzhodnem robu pokopališča, zgrajene I865 (Piškur in Žitko 1997, IO; Sapač 2015, 483). ${ }^{8}$ Pravokotno na njih bi na obeh straneh postavil nove arkade, ki bi skupaj z obstoječimi v tlorisu tvorile obliko črke U. Na tak način bi zamejevale večjo parkovno površino. Na zahodni strani, ob Hramu slave, bi bile zgrajene prehodne arkade, nekakšen vhod na spominski park, tem pa bi proti vzhodu sledil glavni del pokopališča $s \gg s i s-$ temom ograjenih malih pokopališč « (osrednji del), grobnicami (ob južnem zidu) ter nasadi in grobovi (na trikotnem delu ob severnem zidu). Med grobnicami glavnega dela pokopališča in arkadami za Hramom slave bi stal govorniški oder, severno steno pa bi z zunanje strani dopolnjeval niz trgovskih lokalov, ki bi usmerjal potek Linhartove ceste. Najpomembnejše nagrobne spomenike je arhitekt nameraval ohraniti in situ ali pa postaviti ob prizidek k cerkvi sv. Krištofa oziroma dostop do Hrama slave. ' Sočasno z ureditvijo spominskega parka bi evangeličansko

6 Muzej in galerije mesta Ljubljane, Plečnikova zbirka, načrti za Hram slave. Gollmann 2005, 33, ob predstavitvi projekta zgolj pavšalno navaja, da gre za načrt cerkve, ne pa tudi katere. Ostale monografske predstavitve Ravnikarja načrta ne obravnavajo.

$7 \quad$ Temeljna literatura o cerkvi Srca Jezusovega v Pragi: Prelovšek 1992, 229-35; Krečič 1992, 126-31; Prelovšek 1996, 565-79; Hrausky et al. 1998, 165-74; Prelovšek 2017, 232-44.

8 Glede na lego rizalita, lahko sklepamo, da so bile klasicistične arkade že prvotno zamišljene v večjem obsegu in so bile le delno zgrajene (Sapač 2015, 483).

9 France Stele je v tem času sestavil seznam I2 I nagrobnikov, ki jih je potrebno ohraniti bodisi zaradi zgodovinskega pomena bodisi zaradi oblikovnih značilnosti. Omenjene spomenike je mestna uprava leta I932 tudi pravno zaščitila (Piškur in Žitko 1997, 10). 


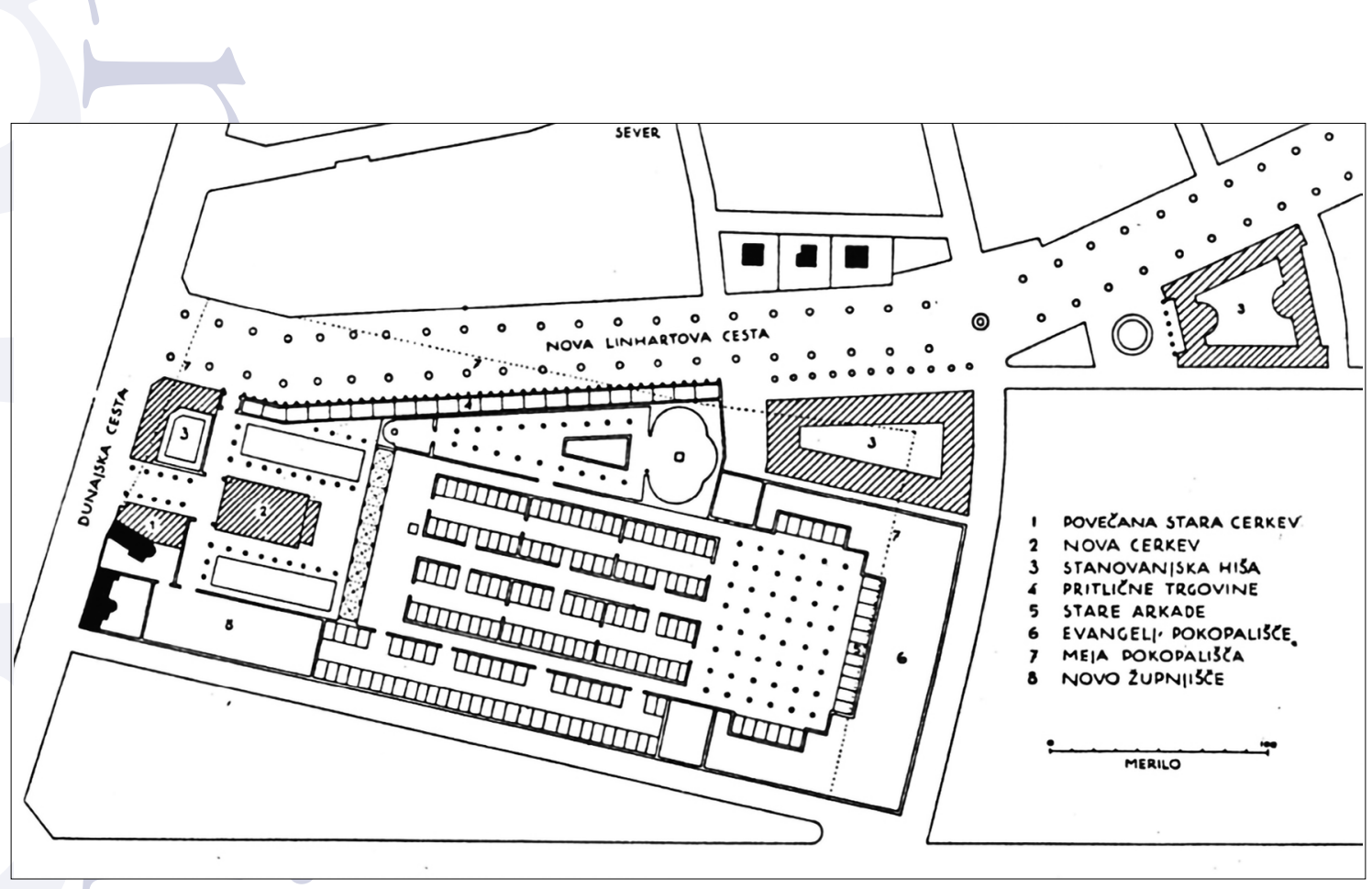

Slika 2: Jože Plečnik: Načrt ureditve Častnega pokopališča zaslužnih Slovencev, Ljubljana, 1932 (po: Stele 1933).

pokopališče, ki se je nahajalo vzhodno od starih arkad in je tvorilo samostojno celoto, odstranili oziroma nadomestili s parkom (Stele 1933, 65-66; Stele 1940, 46-47; Piškur in Žitko 1997, Iо)..$^{\circ}$ Plečnikova rešitev ne bi v enem zamahu rešila le vprašanja opuščenega pokopališča in premajhne cerkve, temveč bi vzpostavila pomemben spominski kompleks, kombinacijo arhitekture, nagrobnih spomenikov in zelenih površin, katerega pomen bi daleč presegal okvire Ljubljane in za katerega bi se po Steletovem mnenju moral zavzeti ves slovenski narod (Stele 1933, 65; Stele 1940,46$)$.

Ta vseslovenski spomenik bi predstavljal enega od ključnih elementov oblikovanja narodne zavesti in bi sodil med tiste narodotvorne spomenike, ki so jih po tedanjih predstavah imeli vsi razviti narodi. »Častno pokopališče zaslužnih Slovencev« (Stele 1933, 65; Stele 1940, 46) bi imelo tudi izjemno vlogo pri kreiranju zgodovinskega spomina slovenskega naroda, ki je

Io Evangeličansko pokopališče, na katerem so prenehali pokopavati 1934, je tudi po ureditvi Navja ostalo na svojem mestu, odstranili so ga šele 1956 in posmrtne ostanke prenesli na Žale (Piškur in Žitko 1997, 12, 18). po letu 1918 vstopil $v$ novo politično stvarnost, pri čemer pa bi morali že $\mathrm{v}$ začetku določiti, nagrobnike katerih oseb bi prezentirali, v čigavi pristojnosti bi bil njihov izbor ipd. V času prve jugoslovanske države smo Slovenci dobili različne ustanove nacionalnega pomena (npr. Univerzo Kraljestva Srbov, Hrvatov in Slovencev v Ljubljani, Univerzitetno biblioteko, Akademijo znanosti in umetnosti, Narodno galerijo), Plečnik pa se je lotil načrtov za vrsto objektov, katerih pomen je daleč presegal mestni nivo (npr. kasnejšo Narodno in univerzitetno knjižnico, neuresničeni načrti za Univerzo in Narodno galerijo v Tivoliju, Banske dvore, Aleksandrove propileje, med drugo svetovno vojno pa npr. za Akademijo znanosti in umetnosti, Odeon ${ }^{\text {II }}$ in pokopališče pomembnih Slovencev s Hramom slave bi zasedalo osrednjo vlogo med njimi. Posebej pa je potrebno poudariti še en pomen načrta, o katerem $v$ javnosti seveda ni bilo govora. Načrt je nastal v času šestojanuarske diktature, ko je bila poudarjena unitaristična ideja enega jugoslovan-

I I neuresničenih načrtih za Ljubljano: Krečič 1990; Krečič et al. 2007 
Slika 3: Jože Plečnik: Hram slave, Ljubljana, 1932, zunanǰ̌čina in prerez (Muzej in galerije mesta Ljubljane, Plečnikova zbirka).

skega naroda, nacionalna gibanja pa preganjana, zato lahko v tem drznem projektu vidimo tudi neke vrste tihi protest proti uradni politiki beograjskih krogov.

Arhitekturne zglede za Plečnikove načrte, zlasti za monumentalni Hram slave, je predstavil že Damjan Prelovšek (Prelovšek 1992, 307; Prelovšek 2017, 365), medtem ko se dosedanji raziskovalci niso posvečali viru same ideje $\gg$ našega Pantheona $\ll$ (Stele 1933, 7I). Stele v predstavitvi projekta v Domu in svetu omenja nekaj spomenikov pri slovanskih narodih, ki igrajo podobno spominsko in narodno konstitutivno vlogo, kot bi jih imela Plečnikova zamisel; Vavel in Skałko v Krakovu, Slavín na praškem Vyšehradu in Mirogoj v Zagrebu (Stele 1933, 7I). Vsi našteti so Plečnikovem načrtu sorodni predvsem po name- nu, po svoji pietetni, spominski, pa tudi vzgojni in izobraževalni vlogi, skratka vlogi nacionalnega panteona, medtem ko so njihove formalne rešitve popolnoma različne. $\mathrm{V}$ obeh poljskih primerih gre za grobnice znotraj cerkve, $v$ češkem za monumentalno grobnico na osrednjem pokopališču, še najbližji po formalni plati je Mirogoj, kjer Stele izpostavi zlasti arkade, pod katerimi so grobovi. Slednje, zgrajene med letoma 1879 in 1917 po načrtih Hermana Bolléja (1845-1926) (Premerl 2000, 74-76), spominjajo na arkade, ki si jih je Plečnik zamislil za okvir parkovnega predela slavnostnega pokopališča.

Ideja nacionalnega spomenika, med katere sodijo tudi $\gg$ nacionalni panteoni $\ll$, je bila v 19 . in začetku 20. stoletja precej aktualna $\mathrm{v}$ evropski arhitekturi, tako so bili Plečniku na voljo naj- 
različnejši bolj ali manj monumentalni zgledi. ${ }^{\mathrm{I}}$ Posebej pa je potrebno poudariti, da so se $\mathrm{v}$ začetku 20. stoletja, torej v času, ko je Plečnik živel na Dunaju, s problemom nacionalnega panteona ukvarjali tudi v šoli njegovega učitelja Otta Wagnerja (184I-I9I8). Tako je Madžar István Benkó Megyaszay (I877-1959) leta 1903 izdelal načrte za Madžarski panteon, ki si ga je zamislil na hribu Gellert nad Budimpešto, na mestu, kjer se nahaja citadela. Oblikoval ga je kot mogočno stavbo, s povišanim osrednjim delom, kritim s kupolo. Do panteona bi vodil kompleksen sistem klančin, ki bi ga ob vznožju hriba obdajala dva stolpa (Pozzetto 1979, IoI). Leto dni kasneje je za diplomsko nalogo Čeh Bohumil Hübschmann (tudi Hypšman, 1878-196I) izdelal načrte Češki panteon, imenovan tudi Gomila preteklosti (Mohyla minulosti). Obsežen kompleks bi tvoril zaključek Vyšehrada, šlo pa bi za veliko stavbo s tlorisom krožnice, ki bi jo kronala betonska kupola velikega razpona, krita $\mathrm{z}$ aluminijasto oblogo, podobno tisti pri Wagnerjevi cerkvi sv. Leopolda na Steinhofu. Stavbo bi na obeh straneh obdajal zid, ki bi ga na eni strani zaključil manjši stolp, na drugi pa kip češke legendarne junakinje Libuše v nadnaravni velikosti, višji od same kupole (Pozzetto 1979, IIO; Kusáková 2013, II; Brůhová 2015, 60). Istega leta 1904 je, tokrat neodvisno od Wagnerjeve šole, nastal tudi načrt za Avstrijsko dvorano slave (Österreichische Völker- und Ruhmeshalle) na Leopoldsbergu v 19. dunajskem okraju, ki sta ga izdelala Karl Troll (1865-1954) in Franz Biberhofer (1859-?), za idejnega očeta te »avstrijske Valhale« pa velja pisatelj in filozof Richard von Kralik (18521934). Sestavljala bi jo osrednja dvorana s cesarjevim konjeniškim spomenikom, stenskimi poslikavami, kipi, mozaiki in slikanimi okni s prizori iz avstrijske zgodovine od rimskih časov dalje, prostor pa bi obdajali babenberška in habsburška dvorana. Mogočno, bogato okrašeno stavbo, bi tudi v tem primeru kronala kupola, ki bi se $\mathrm{v}$ zgornjem delu zaključila s cesarsko krono. Tako kot prejšnja dva, tudi ta ambiciozni projekt ni bil uresničen, in to navkljub dejstvu, da so I9Is zanj

I2 O problematiki nacionalnih spomenikov: Pevsner 1976, I I-26. celo razpisali javni natečaj (Kassal-Mikula 1999, 220-21; Telesko 2008, 22).

Plečniku tako ideja nacionalnega panteona brez dvoma ni bila neznana in po vsej verjetnosti je poznal omenjene tri načrte, med drugim zato, ker so nastajali v času, ko je živel in delal na Dunaju. ${ }^{\mathrm{I3}}$ Seveda pa je rešitev, ki jo je približno tri desetletja kasneje predlagal v Ljubljani, precej drugačna. Izjemna je že lega $\gg$ Slovenskega panteona «, saj se ta ne bi nahajal na hribu, temveč $\mathrm{v}$ ravnini, $\mathrm{v}$ novonastajajočem delu mesta, precej večji poudarek pa bi bil namenjen parkovnim površinam, kar je nenazadnje povezano $s$ težnjo po ohranitvi obstoječih nagrobnikov in situ. Skupen vsem projektom pa je osrednji objekt monumentalnih mer, vendar se Plečnik odpove kupoli, priljubljeni pod vplivom Wagnerjeve cerkve na Steinhofu, namesto nje pa ima njegov Hram slave unikatno obliko, ki jo odlikuje trikotni zvonik.

Plečnikov ambiciozni načrt je ostal torzo, ključni razlog za njegovo neuresničitev pa ni bilo ne ves čas prisotno pomanjkanje finančnih sredstev (Prelovšek 1992, 307; Prelovšek 2017, 365) ne politika, temveč lastnik zemljišča, ljubljanska škofija. Ljubljanski škof dr. Gregorij Rožman (1883-1959) je sprejel še danes težko razumljivo odločitev, na področju opuščenega pokopališča zgraditi nov škofijski kompleks (Prelovšek 1992, 277; Hrausky et al. 1996, 179; Prelovšek 2017, 33I). Kasneje je velikopotezni projekt omejil le na gradnjo novega semenišča, imenovanega po misijonarju Frideriku Baragi (Stele 1940, 47; Štrukelj 1940, 69-71; Prelovšek 1992, 307-8; Krečič 1992, 261-65; Hrausky et al. 1996, 179-8I; Prelovšek 2017, 366-67). Plečnik se je tako vdal v usodo in leta 1936 izdelal ambiciozne načrte za Baragovo semenišče, stavbo $s$ tlorisom v obliki krožnice, na severni strani obdane z monumentalnim vhodnim krilom. Slednje bi bilo razširjeno z nizom pritličnih trgovin, ki bi usmerjal potek nove trase Linhartove ceste.

\footnotetext{
I3 Zagotovo je poznal Trollove in Biberhoferjeve načrte za Avstrijsko dvorano slave, saj so bili razstavljeni na 2. razstavi Leonove družbe (Kassal-Mikula 1999, 220). Ta je potekala od 3. decembra 1904 do I. januarja I905 v Künstlerhaus na Dunaju, Plečnik pa je bil eden od članov organizacijskega odbora razstave (Prelovšek 1979, 195).
} 


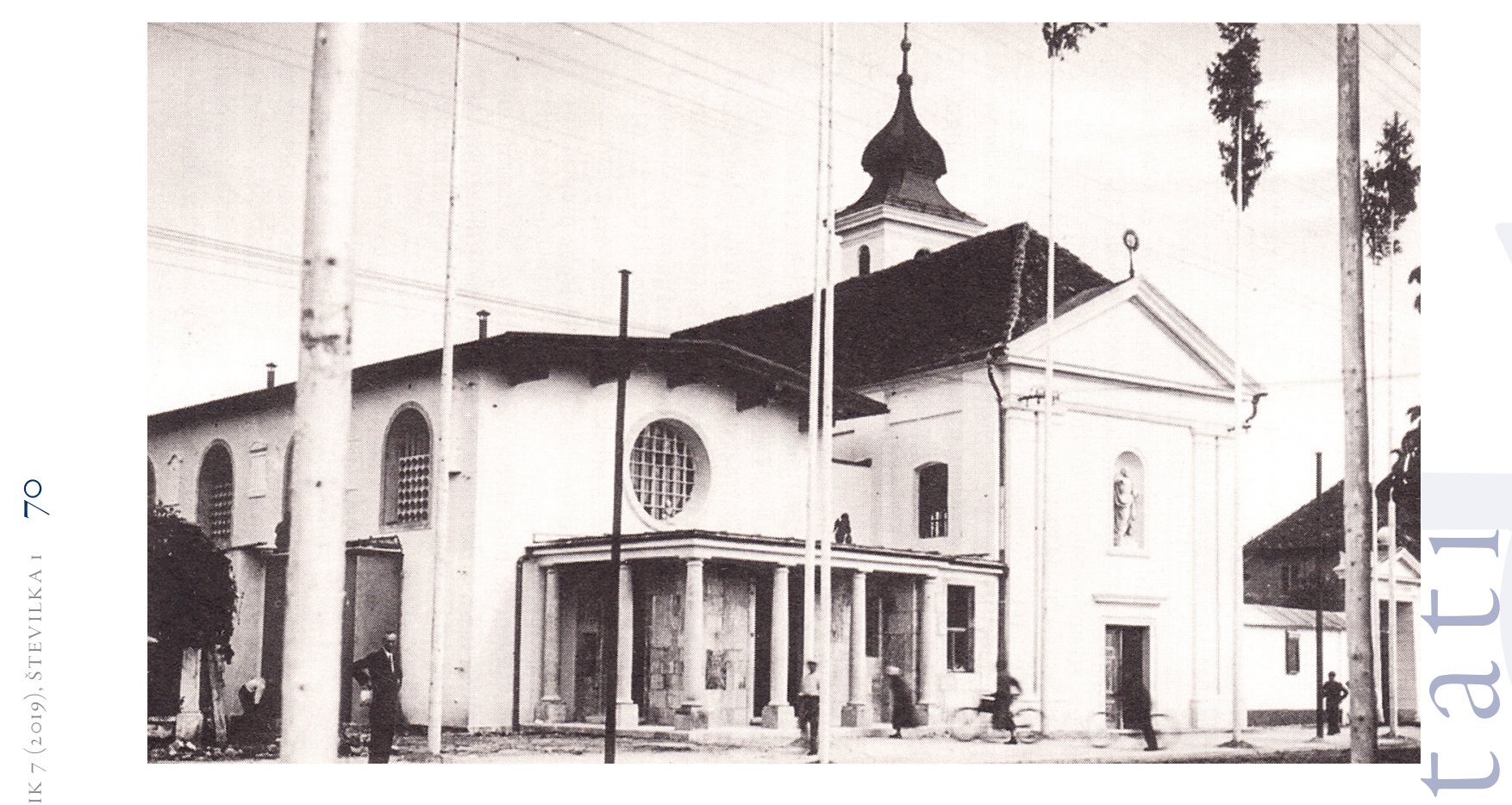

Slika 4: Jože Plečnik: Župnijska cerkev sv. Cirila in Metoda (prizidek cerkve sv. Krištofa), Ljubljana, 1933-1934, porušena $1957-1958$ (po: Razbočan 1995).

Semenišče so pričeli graditi 1938 in ga do začetka druge svetovne vojne zgradili približno do polovice, $v$ petdesetih letih pa po načrtih arhitektovega učenca Toneta Bitenca (1920-1977) le zasilno dokončali in namenili profanim funkcijam (Akademski kolegij, Festivalna dvorana, Kino Soča, Pionirski dom, Mladinsko gledališče), dela so bila končana 1955 (Krečič 1992, 257; Hrausky et al. 1996, 179). Neposredno po začetku gradnje je prišlo do konflikta med arhitektom in vodjem gradnje, inž. Antonom Suhadolcem (1897-1983), ki je menda samovoljno spremenil nekaj detajlov, zato se je Plečnik načrtu odrekel (Krečič i985, II5; Prelovšek 1992, 308; Krečič 1992, I57; Hrausky et al. 1996, 179; Prelovšek 2017, 367).

$S$ tem, ko je pristal na zamisli ljubljanskega škofa, se je Plečnik sam odpovedal svojemu projektu parka pomembnih Slovencev, resnici na ljubo pa drugih možnosti niti ni imel. Kot nekakšen torzo je ostal le prizidek k cerkvici sv. Krištofa, nova cerkev sv. Cirila in Metoda (1933-1934), izjemno zanimiv objekt, ki priča o Plečnikovem izjemnem občutku za povečevanje sakralnih stavb, saj je ne le ohranil vse arhitekturno in umetnostno pomembne elemente stare zgradbe, temveč je novo cerkev vkomponiral tako domiselno, da ni »nadglasila « baročne predhodnice (Stele 1933, 66-68; Stele 1940, 4852; Krečič 1992, 257-61; Krečič i995, 83-86; Hrausky et al. 1996, I85, I87-89; Valena 2013, 24748). Tudi pri zasnovi prizidka lahko opazujemo Plečnikove težnje po ohranjanju spomina, saj je nekatere nagrobnike iz opuščenega pokopališča dal vzidati v cerkveno zunanjščino (Krečič 1992 , I60), prav tako so v cerkev prenesli posmrtne ostanke nekaterih pomembnih Slovencev; njihova imena je Plečnik obeležil na ploščah, ki obdajajo stene prezbiterija (Krečič I995, 87; Piškur in Žitko 1997,12$){ }^{14}$

Po propadu projekta pokopališča pomembnih Slovencev je Plečnik skušal »rešiti, kar se rešiti $\mathrm{da} \ll$. Pomembno spodbudo je predstavljala pobuda mestnega svetnika Viktorja Andrejke (I88I-1947), ki se je konec leta 1936 ponovno zav-

I4 Poleg njih so na ploščah navedeni tudi dobrotniki cerkve (Krečič 1992, 159; Razbočan 1995, 20). 


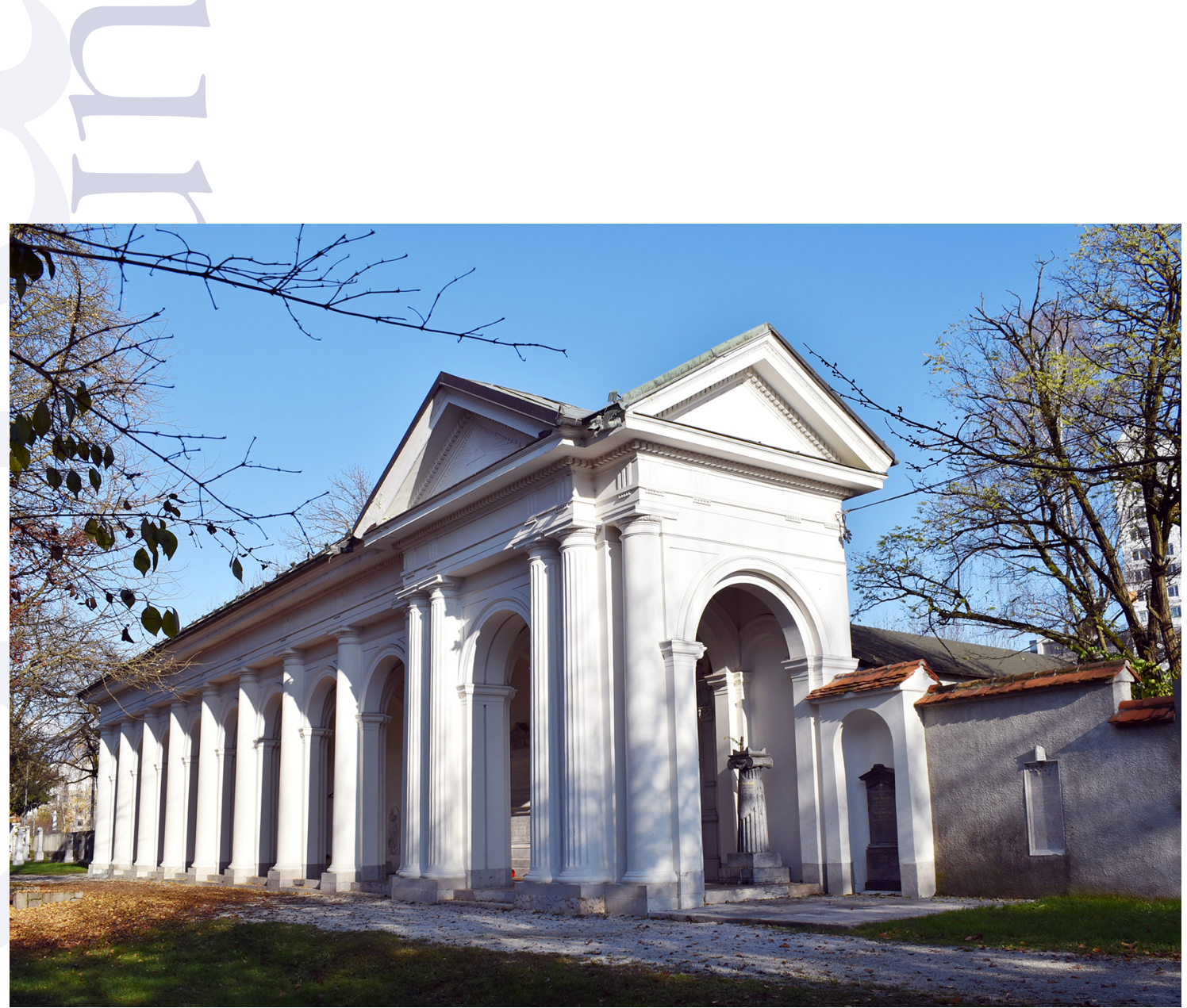

Slika 5: Jože Plečnik: Navje, Ljubljana, 1937-1938. (Foto: K. Šmid).

zel za ureditev parka slavnih, na podlagi česar je škof Rožman, po Plečnikovem nasvetu, sklenil mestni občini odstopiti vzhodni del nekdanjega pokopališča, ob klasicističnih arkadah (Stele 1940, 47-48; Mole 1940, 72; Piškur in Žitko 1997, 13). Na tem mestu so po Plečnikovih načrtih v letih 1937-1938 uredili spominski park Navje (Bajuk 1940, I-2; Mole I940, 72; Hrausky et al. 1996, I85; Piškur in Žitko 1997, I4-17). Hrbtenico novega projekta so zopet predstavljale obnovljene klasicistične arkade, ki so jih po arhitektovih načrtih na krajših stranicah odprli, s čimer so poudarili njihovo prehodnost. ${ }^{\text {I5 }}$ Pod njih je dal Plečnik pokopati nekatere pomembne Slovencev, druge so pokopali v bližino arkad ali pa tja postavili le njihove nagrobnike (Mole 1940, 73). Okolico arkad je Plečnik parkovno uredil, nekaj nagrobnikov, med njimi grob svojih staršev, pa ohranil in situ. Park je na južni strani do-

is Fotografija arkad pred Plečnikovo prenovo: Piškur in Žitko 1997, 14. bil vhod, v stene katerega so vzidali fragmente nagrobnikov, železna vrata pa so izdelana iz ograje ene od opuščenih grobnic (Mole 1940, 7274, Prelovšek 1992, 308; Hrausky et al. 1996, 185; Piškur in Žitko 1997, I 4-19; Prelovšek 2017, 367). Navje je bilo od začetka zamišljeno kot spomenik vsem pomembnim Slovencem, na kar kaže tudi dejstvo, da so nanj prepeljali posmrtne ostanke nekaterih pomembnih osebnosti iz drugih ljubljanskih pokopališč, leta I940 pa so tu pokopali tudi najpomembnejšega slovenskega politika časa med obema svetovnima vojnama, dr. Antona Korošca (1872-1940), kar je bil tudi zadnji pokop na Navju, saj je načrtovane prekope drugih uglednih pokojnikov preprečila druga svetovna vojna. Koroščev grob, v katerega naj bi pokopali tudi njegovega naslednika, dr. Franca Kulovca (I884-194I), je tudi edini, ki ga je zasnoval Plečnik (Hrausky et al. 1996, I85-86; Piškur in 


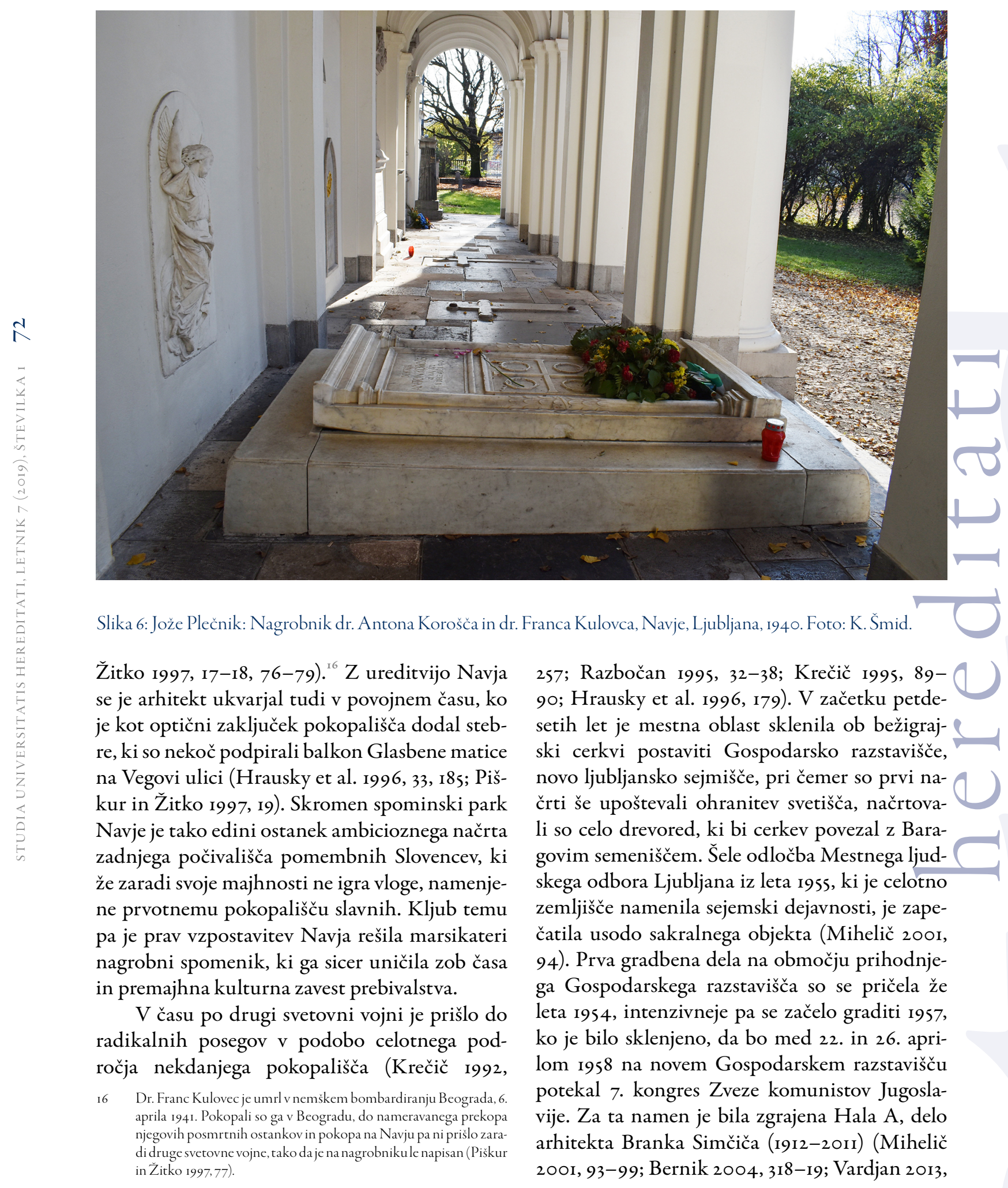


226-3I), sočasno z gradnjo pa so porušili župnijsko cerkev, najprej decembra 1957 Plečnikov prizidek, februarja 1958 pa še staro Krištofovo cerkev (Razbočan 1995, 36). ${ }^{17}$ Plečnikova cerkev sv. Cirila in Metoda je bila z velikanskim angažmajem tamkajšnjih frančiškanov, še zlasti župnika p. Krizologa Zajca, pod vodstvom Toneta Bitenca prestavljena na Vodovodno ulico (Razbočan 1995, 36; Krečič 1995, 90-92), ne pa tudi baročna cerkev sv. Krištofa, zaradi česar je Plečnikova mojstrovina izgubila svoj estetski učinek (Krečič 1992, 257; Hrausky et al. 1996, I89; Valena 2013, 249, op. 33). Nekaj časa je bila negotova tudi usoda Navja, saj so resno razmišljali o selitvi nagrobnikov na Žale ali katero drugo pokopališče, zaradi česar so bila v spominskem parku dovoljena le nujna vzdrževalna dela (npr. košnja, manjši ureditveni posegi) (Šumi 1960-1961, I23; Piškur in Žitko 1997, 18-20), Plečnik pa je celo pripravil načrte $\mathrm{za} \gg$ novo Navje $\ll \mathrm{v}$ obliki spominske aleje med Žalami in parcelo nasproti njih (Šumi 1960-1961, I23; Hrausky et al. 1996, I85; Piškur in Žitko 1997, 20). ${ }^{18} \mathrm{Na}$ srečo do selitve ni prišlo in tako so Navje ostale edini ostanek ambicioznega vseslovenskega projekta. Čeprav imajo Navje izjemen zgodovinski in kulturni pomen, pa že zaradi svoje majhnosti, pa tudi večdesetletnega zanemarjanja, ki se je končalo šele v osemdesetih letih, ne igrajo vloge, ki bi jo igral prvotno zamišljeni projekt »častnega pokopališča zaslužnih Slovencev«.

$\gg$ Prekrasni arhitektov sen o našem Pantheonu $<$ (Stele 1933, 7I) brez dvoma predstavlja enega najbolj dovršenih Plečnikovih načrtov za Ljubljano. Izjemno večplasten projekt, s katerim bi arhitekt rešil vprašanje usode opuščenega pokopališča, bi hkrati postavil temelje urbanistični ureditvi Bežigrada in omogočil gradnjo nove žu-

17 Na mestu župnijske cerkve sedaj stoji paviljon Jurček, delo Marka Šlajmerja (1927-1969) iz leta 1960.

18 Projekti o opustitvi Navja in preselitvi nagrobnikov na Žale so bili aktualni vse do leta 1980, ko je selitev, za katero so že potekale priprave, preprečilo nasprotovanje Društva slovenskih pisateljev, Društva za varstvo okolja Ljubljane in nekaterih drugih organizacij in posameznikov. Nekaj časa je celo veljalo, da Navje predstavlja oviro širitvi glavne železniške postaje. Šele 1981 je Skupščina mesta Ljubljana sprejela sklep o obnovi in trajnem vzdrževanju spominskega kompleksa Navje na obstoječi lokaciji (Piškur in Žitko 1997, 20; Arh Kos 1997, 22) pnijske cerkve, predvsem pa bi imel močan nacionalni naboj, saj bi se na njegovi podlagi sčasoma izoblikovalo eno od kulturnih in pietetnih središč Slovencev. Pomembno bi vplival na oblikovanje zgodovinskega spomina slovenskega naroda, imel pa bi tudi izjemno izobraževalno vlogo. Le obžalujemo lahko, da ambiciozni načrti, nastali v času precejšnjih pritiskov unitaristično usmerjenih beograjskih oblasti, zaradi kratkovidnosti nekaterih akterjev niso bili uresničeni, saj je bila s tem zamujena izjemna priložnost, da bi tudi Slovenci dobili svoj nacionalni spomenik, kot ga ima večina »velikih « narodov. ${ }^{\text {I9 }}$

\section{Povzetek}

Najpomembnejši slovenski arhitekt Jože Plečnik (I8721957) se je vse od leta 1924 posvečal urbanističnemu urejanju severnega dela Ljubljane, Bežigrada. V regulacijskem načrtu, objavljenem 1929, je med drugim predlagal rešitev za opuščeno pokopališče pri sv. Krištofu, glavno ljubljansko pokopališče med letoma 1779 in 1906, na katerem je bila ohranjena vrsta nagrobnikov pomembnih Slovencev. V podrobnejših načrtih (1932) je predvidel povečanje cerkve sv. Krištofa, zidavo nove monumentalne cerkve (t. i. Hrama slave), kakor tudi preureditev preostalega območja pokopališča v spominski park, enkratno kombinacijo arhitekture, zelenih površin in grobov pomembnih Slovencev. »Častno pokopališče zaslužnih Slovencev« bi s tako postalo Slovenski panteon in bi igralo pomembno vlogo pri oblikovanju zgodovinskega spomina in spodbujanju narodne zavesti. Še več, projekt lahko obravnavamo tudi kot tihi protest proti tedanji jugoslovanski politiki, ki je forsirala idejo enotnega jugoslovanskega naroda.

Čeprav je bilo v 19. in zgodnjem 20. stoletju v Evropi zgrajenih ali načrtovanih več nacionalnih panteonov, tematika pa je bila v začetku 20. stoletja priljubljena tudi na Dunaju (še zlasti v šoli Plečnikovega učitelja Otta

\footnotetext{
I9 Raziskave za pričujoči prispevek so potekale na ZRC SAZU, Umetnostnozgodovinskem inštitutu Franceta Steleta, v okviru raziskovalnega programa Slovenska umetnostna identiteta v evropskem okviru (P6-006I), ki ga sofinancira Javna agencija za raziskovalno dejavnost Republike Slovenije, in na Univerzi v Mariboru, Filozofski fakulteti, v okviru aplikativnega raziskovalnega projekta Mapiranje urbanih prostorov slovenskih mest v zgodovinskem okviru. Modernistična Nova Gorica in njeni konteksti (L6-8262), ki ga sofinancirajo Javna agencija za raziskovalno dejavnost Republike Slovenije, Slovenska akademija znanosti in umetnosti ter Mestna občina Nova Gorica.
} 
Wagnerja), je potrebno poudariti, da Plečnikova rešitev iz arhitekturnega vidika ne spominja na nobenega od starejših nacionalnih panteonov.

Žal Plečnikova zamisel nikoli ni bila uresničena, ker se je lastnica zemljišča, ljubljanska škofija, odločila na njem zgraditi novo stavbo semenišča (ki jo je prav tako načrtoval Plečnik). Od prvotnega projekta je bil tako uresničen le prizidek k cerkvi sv. Krištofa, tj. župnijska cerkev sv. Cirila in Metoda, ki so jo zgradili med letoma 1933 in 1934. Poleg tega pa je bil v letih 1937-1938 na vzhodnem robu nekdanjega pokopališča po Plečnikovih načrtih urejen manjši spominski park Navje.

Po drugi svetovni vojni je bilo celotno območje nekdanjega pokopališča znova preurejeno, saj se je lokalna oblast odločila na njem zgraditi mestno sejmišče (Gospodarsko razstavišče), ki so ga začeli graditi 1954, gradnjo pa je pospešila odločitev, da bo v aprilu 1958 na njem potekal 7. kongres Zveze komunistov Jugoslavije. Sočasno z izgradnjo Hale A (Branko Simčič, 1957-1958) je bila podrta bežigrajska župnijska cerkev in le Plečnikov prizidek je bil kasneje rekonstruiran na drugi lokaciji, ne pa tudi cerkev sv. Krištofa. Tudi usoda Navja je bila kar nekaj desetletij nejasna, saj so bili načrti za selitev nagrobnikov na glavno ljubljansko pokopališče, Žale, aktualni vse do leta 1980. Čeprav se je situacija precej izboljšala po letu 198I, ko je bilo Navje spomeniško zaščiteno, pa spominski park zaradi svoje majhnosti, pa tudi desetletij zanemarjanja, ne igra vloge, ki bi jo "Častno pokopališče zaslužnih Slovencev".

Danes lahko le obžalujemo, da ni prišlo do uresničitve Plečnikovega Slovenskega panteona, saj bi ta predstavljal izjemno arhitekturno rešitev, pomembno sredstvo za oblikovanje slovenskega zgodovinskega spomina, imel pa bi tudi pomembno vzgojno-izobraževalno vlogo in bi bil ključen za spodbujanje slovenske narodne zavesti.

\section{Summary}

The most important Slovenian architect Jože Plečnik (1872-1957) was 1924 engaged in the urban planning of Ljubljana’s northern district Bežigrad. In his urban plan, published in 1929 , he also proposed the solution for the abandoned St. Christopher cemetery, which was the main cemetery of Ljubljana from 1779 until 1906 and thus contained the graves of many important Slovenians. In his detailed plans (1932) Plečnik proposed the en- largement of St. Christopher church, construction of the new monumental church (so-called Hall of Fame) as well as rearrangement of the rest of cemetery in the memorial park, unique combination of architecture, nature and tombs of important Slovenians. "Honorary cemetery of important Slovenians" would thus become a Slovenian Pantheon and would play an important role in defining the historical memory as well as creating the national consciousness. Furthermore, the project can also be observed as a kind of protest against contemporary Yugoslav politics, who promote the idea of a single Yugoslav nation.

Although several national pantheons were built or designed in Europe in $19^{\text {th }}$ and early $20^{\text {th }}$ century and that the topic of national pantheon was popular in early 1900's Vienna (especially in the school of Plečnik's teacher Otto Wagner) Plečnik's solution is unique from architectural point of view and does not resemble and of the older national pantheons.

Unfortunately, the project was never executed, because the owner of the territory, the Diocese of Ljubljana, decided to build a new priest seminary building (also designed by Plečnik) in the middle of it. From the original project only the extension of St. Christopher church, i. e. the parish church of St. Cyril and Methodius, was constructed in 1933-1934. In addition, on the eastern part of former cemetery the much smaller Navje memorial park was established according to Plečnik's plan in $1937-1938$.

After the Second World War the whole territory of former cemetery was rearranged again, because the local authorities decided to build a city fair (Ljubljana Exhibition and Convention Centre). The construction started in 1954 , but the decision to held there the $7^{\text {th }}$ Congress of the League of Communists of Yugoslavia on April 1958, stimulated the construction significantly. For that reason, the exhibition hall A (Branko Simčič, 1957-1958) was built and at the same time Bežigrad parish church was demolished. Only Plečnik's extension, church of St. Cyril and Methodius, was later reconstructed on another location, while St. Christopher church was not. Also the destiny of Navje Memorial park remained open for several decades, since the plans for removing the gravestones to Žale Central cemetery were current until 1980. Although the situation has much improved since 1981, when Navje Memorial park was put under mon- 
ument protection, due to its smallness and decades of neglecting, Navje never played the role that "Honorary cemetery of important Slovenians" would.

From today's point of view, we can only regret, that Plečnik's Slovenian Pantheon was never executed, since it would be a unique architectural solution, an important mean of creating the Slovenian historical memory, it would have a significant pedagogical role and it would be crucial for establishing Slovenian national consciousness.

\section{Viri in literatura}

Muzej in galerije mesta Ljubljane, Plečnikova zbirka

Arh Kos, M. 1997. "Spomeniškovarstvena problematika Navja po letu 1980.” V Ljubljansko Navje, ed. M. Piškur in S. Žitko 22-24. Ljubljana: Državna založba Slovenije.

Bajuk, M. 1930. Vodnik po ljubljanskih pokopališcih. Ljubljana: Jugoslovanska knjigarna.

Bajuk, M. 1940. Navje. Ljubljana: Kulturni odsek mestnega poglavarstva.

Bernik, S. 2004. Slovenska arhitektura dvajsetega stoletja / Slovenian Architecture of the Twentieth Century. Ljubljana: Mestna galerija.

Brůhová, K. 2015. "Architektura Bohumila Hübschmanna: konstrukce a estetika.” Beton: technologie, konstrukce sanace 5: 6063.

Fabiani, M. 1899. Regulacija deželnega stolnega mesta Ljubljane. Dunaj: samozaložba.

Gollmann, K. F. 2005. Edvard Ravnikar: Bauten und Projekte: Die Fortsetzung einer mitteleuropäischen Architekturtradition. Wien-Graz: Neuer Wissenschaftlicher Verlag.

Gostiša, L., ur. 1986. Arhitekt Jože Plečnik: Razstava v Ljubljani 1986, Ljubljana: Delavska enotnost.

Hrausky, A., J. Koželj in D. Prelovšek. 1996. Plečnikova Ljubljana: Vodnik po arbitekturi. Ljubljana: Dessa.

Hrausky, A., J. Koželj in D. Prelovšek. 1998. Plečnikv tujini: Vodnik po arhitekturi. Ljubljana: Dessa.
Kassal-Mikula, R. 1999. "Karl Troll und Franz Biberhofer 1904: Österreichische Ruhmeshalle auf dem Leopoldsberg." V Das ungebaute Wien: Projekte für die Metropole: I800 bis 2000, 220-2I.Wien: Historisches Museum der Stadt Wien.

Krečič, P., ur. 1985. Plečnik in jaz: Pisma Jožeta Plečnika Antonu Suhadolcu: Suhadolčevi spomini na Plečnika. Trst: Založništvo tržaškega tiska.

Krečič, P., ur. 1990. Monumentalni (nerealizirani) načrti za Ljubljano Jožeta Plečnika. Ljubljana: Arhitekturni muzej Ljubljana.

Krečič, P. 1992. Jože Plečnik. Ljubljana: Državna založba Slovenije.

Krečič, P. 1995. "Sveti Krištof in sveta Ciril in Metod." V Naš Bežigrad: župnija sv. Cirila in Metoda Ljubljana Bežigrad ob šestdesetletnici 1934-1994, uredil Franci Seničar, 78-94. Ljubljana: Župnijski urad Ljubljana-Bežigrad.

Krečič, P., V. Miškovič in D. Prelovšek. 2007. Da ne pride vpogin in pozabljenje: Plečnikova vizija Ljubljane - slovenskih Aten: arhitektov dar knjižnici. Ljubljana: Narodna in univerzitetna knjižnica.

Kusáková, A. 2013. "Bohumil Hypšman - moderní architekt v historickém městě.” Dipl. naloga, Univerzita Karlova v Praze.

Lavrič, A. 2012. "Ljubljanska cerkev sv. Krištofa za Bežigradom.” Kronika: Časopis za slovensko krajevno zgodovino 60 (I): 7-22.

Lenarčič, V. 1940. “Razvoj Bežigrada.” V Naš Bežigrad: V luči zgodovine, kulture, gospodarstva, uredila Vilko Fajdiga in France Jesenovec, 36-44. Ljubljana: Stavbarska zadruga Bežigrajski dvor.

Mihelič, B. 200I. "Gospodarsko razstavišče." V 2o. stoletje: Arbitektura od moderne do sodobne: Vodnik po arbitekturi, uredila Damjana Prešeren, 93-99. Ljubljana : Zavod za varstvo kulturne dediščine Slovenije.

Mihelič, B. 2008. "Maks Fabiani in dunajski urbanizem na prelomu 19. stoletja." Urbani izziv 19 (I): 5-10. 
Mole, R. 1940. "Navje." V Naš Bežigrad: Vluči zgodovine, kulture, gospodarstva, uredila Vilko Fajdiga in France Jesenovec, 7278. Ljubljana: Stavbarska zadruga Bežigrajski dvor.

Pevsner, N. 1976. A History of Building Types. London: Thames and Hudson.

Piškur, M. in S. Žitko. 1997. Ljubljansko Navje. Ljubljana: Državna založba Slovenije.

Piškur, M. 2004. Ljubljanske Žale: Vodnik po pokopališču. Ljubljana: Družina.

Plečnik, J. 1929. "Studija regulacije severnega dela Ljubljane." Dom in svet 42 (3): 91.

Plečnik, J., ed. 1937. Lučine: Nadaljevanje: 118 izbranih del arhitektov Tehnike Univerze ljubljanske: 1929-1937. Ljubljana: Ognjišče akademikov arhitektov.

Prelovšek, D. 1979. Josef Plečnik: Wiener Arbeiten von I896 bis I9I4. Wien: Edition Tusch.

Prelovšek, D. 1992. Josef Plečnik (1872-1957): Architectura perennis. Salzburg-Wien: Residenz Verlag.

Prelovšek, D. 1996. "Kostel Nejsvětějšího Srdce Páně v Praze." V Josip Plečnik: Architekt Pražského hradu, uredili Zdeněk Lukeš, Damjan Prelovšek in Tomáš Valena, 56579. Praha: Správa Pražského hradu.

Prelovšek, D. 2017. Jože Plečnik: Arhitektura večnosti: Teme, metamorfoze, ideje. Ljubljana: Založba ZRC.

Premerl, T. 2000. "Bolléov Mirogoj -nadrastanje vremena i stila."

V Historicizam u Hrvatskoj I, 73-79. Zagreb: Muzej za umjetnost i obrt.

Pozzetto, M. 1979. La scuola di Wagner 1894IgI2: Idee, premi, concorsi. Trieste: Comune di Trieste.

Pozzetto, M. 1983. Max Fabiani: Ein Architekt der Monarchie. Wien: Edition Tusch.

Pozzetto, M. 1997. Maks Fabiani - vizije prostora. Kranj: Libra.

Razbočan, R. 1995. "Kronološki prikaz ustanovitve in delovanja župnije.” V Naš Bežigrad: župnija sv. Cirila in Metoda Ljubljana Bežigrad ob šestdesetletnici 1934-1994, uredil Franci Seničar, 7-77.
Ljubljana: Župnijski urad Ljubljana-Bežigrad.

Sapač, I. 2015. "Katalog pomembnejših klasicističnih, bidermajerskih in historističnih arhitekturnih stvaritev na območju Republike Slovenije." V Sapač, I. in F. Lazarini. Arbitektura 19. stoletja na Slovenskem, 36I677. Ljubljana: Muzej za arhitekturo in oblikovanje, Fakulteta za arhitekturo.

Stabenow, J. 1996. Jože Plečnik: Städtebau im Schatten der Moderne. Braunschweig-Wiesbaden: Vieweg.

Stele, F. 1933. "Hram Slave pri sv. Krištofu." Dom in svet 46 (I-2): 64-7I.

Stele, F. 1940. "Veliki načrti." V Naš Bežigrad: $V$ luči zgodovine, kulture, gospodarstva, uredila Vilko Fajdiga in France Jesenovec, 44-55. Ljubljana: Stavbarska zadruga Bežigrajski dvor.

Steska, V. 1940. "Iz nekdanjih dni." V Naš Bežigrad: V luči zgodovine, kulture, gospodarstva, uredila Vilko Fajdiga in France Jesenovec, 25-31. Ljubljana: Stavbarska zadruga Bežigrajski dvor.

Štrukelj, T. 1940. “Baragovo semenišče.” V Naš Bežigrad: Vluči zgodovine, kulture, gospodarstva, uredila Vilko Fajdiga in France Jesenovec, 69-71. Ljubljana: Stavbarska zadruga Bežigrajski dvor.

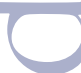

Šumi, N. 1960-1961. "Ljubljana, prenos in preureditev Navja." Varstvo spomenikov 8: I23.

Telesko, W. 2008. Kulturraum Österreich: Die Identität der Regionen in der bildenden Kunst des Ig. Jahrbunderts. Wien-Köln-Weimar: Böhlau Verlag.

Valena, T. 2013. O Plečniku: Prispevkik preučevanju, interpretaciji in popularizaciji njegovega dela. Celje: Celjska Mohorjeva družba.

Vardjan, M. 2013. "Hala A Gospodarsko razstavišče Ljubljana.” V Čelik, M., M. Vardjan in B. Zupančič. Pod skupno streho: Moderne javne zgradbe iz zbirke MAO in drugih arhivov, 226-31. Ljubljana : Muzej za arhitekturo in oblikovanje. 
Zakrajšek, K. 1940. "Od sv. Krištofa do sv. Cirila in Metoda." V Naš Bežigrad: V luči zgodovine, kulture, gospodarstva, uredi-

la Vilko Fajdiga in France Jesenovec, 5668. Ljubljana: Stavbarska zadruga Bežigrajski dvor.

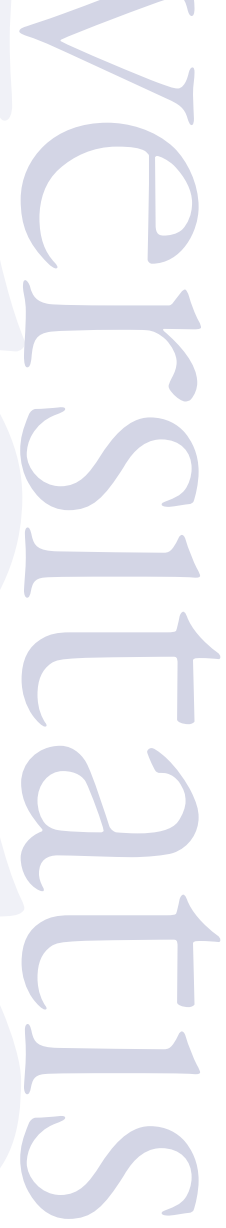





\title{
Odtujevanje kulturne dediščine: primer premeščenih artefaktov iz mest Slovenske Istre
}

\author{
Janja Babelić, mag. umetnostne zgodovine
}

Med drugo svetovno vojno, ko so obalna mesta pripadala Italiji, je bilo zaradi nevarnosti vojne iz omenjenih krajev premeščenih nekaj predmetov kulturne dediščine. Problematika restitucije umetnin je tako na Slovenskem kot drugod že nekaj desetletij pereč problem. Cilj prispevka je strnjeno predstaviti historični pregled po vojni odtujenih artefaktov iz obalnih mest, $\mathrm{z}$ namenom postavitve trdnih temeljev za nadaljne raziskave.

Ključne besede: kulturna dediščina, 2. sv. vojna, Slovenija, Italija, restitucija.

During World War II, when the coastal towns of Slovenia were part of Italy, many of heritage objects and artifacts were taken to safety and relocated because of bombing threats. The problem of restitution of artifacts is still today a burning question in Slovenia and others parts of the world. The scope of this article is to give a condensed historical review on the fate of the relocated artifacts from the coastal towns, because further research must be placed on solid foundations.

Key words: cultural heritage, WWII, Slovenia, Italy, restitution.

M ed drugo svetovno vojno, ko so obalna mesta severne Istre pripadala Italiji, je bilo zaradi nevarnosti vojne od tam premeščenih nekaj predmetov kulturne dediščine. Predmeti so bili odpeljani na varno, vendar se zaradi sprememb meja $v$ teh okrajih niso nikdar vrnili na svojo izvorno lokacijo. Kmalu po drugi svetovni vojni je Jugoslavija ustanovila komisijo za restitucijo artefaktov ${ }^{\mathrm{I}}$. Cilj prispevka je strnjeno predstaviti usodo po vojni odtujenih artefaktov iz obalnih mest, $\mathrm{z}$ namenom, da bi te raziskave bile $\mathrm{v}$ prihodnje nadgrajene. $\check{Z}_{\mathrm{i}}$ vimo $\mathrm{v}$ času, ko je tematika vračanja umetnin zelo prikladna za politične in populistične namene. Zaradi tega je nujna kontekstualizacija in poglobljena analiza podobnih primerov. Uporabljena metodologija je preplet pregleda umetnostnozgodovinskih, zgodovinskih in arhivskih vi-

I Pojem artefakt v tem kontekstu uporabljam kot širšo definicijo, ki zajema sakralno in profano premično kulturno dediščino. rov. Historični pregled v tem članku predstavlja le temelje za nadaljnje raziskave na tem področju, ker je problem odtujenih umetnin izjemno zahteven za raziskavo, saj pokriva različna raziskovalna področja.

Po Ashworthu je ravno pomen, ki ga pripisujemo dediščini, tisti, ki ji določa vrednost (Ashworth in soavtorji 2007, 3). Nacionalna dediščina je del javne kulturne in zgodovinske sfere, je del procesa vlade in vladanja (Mason in Baveystock 2009, 17). Marta Anico (2009, 63) piše, da je dediščina izjemno učinkovito sredstvo za uveljavljanje kontinuitete in stabilnosti, ki omogoča družbam definiranje in sidranje njihove identitete. Kot jasno kažejo sodobne razlage s področja kritičnih dediščinskih študij, artefakti in nesnovni elementi dobijo vrednost dediščine skozi proces dediščinjenja (heritageisation; Harvey 200I), ki ga sooblikujejo diskurzi. Avtorizirani diskurz v dediščini je tisti, katerega no- 
silci so politične elite in strokovnjaki, stremijo pa h konsenzualnem, narodotvornem tolmačenju zgodovine, in torej dediščine; obratno pa subalterni diskurz temelji na vključujočem načelu različnih družbenih (nehegemonskih) skupin in odpira prostor za konfrontacijo različnih razlag (Smith 2006, 4-6). Dediščina je torej vedno bila ideološko osnovana, je simbolični konstrukt pod vplivom zgodovine, politike in družbenih okvirjev, v katerih nastanejo in so interpretirani kulturni pomeni (Anico 2009, 63), s tem pa instrument kulturne moči (Harvey 200I, I5).

Obstoj neke stvari, po Benjaminu (2003, I5I), je zbir vsega, kar ji je od začetka dodala tradicija, od njenega materialnega trajanja vse do zgodovinskega pričevanja. Enkratna vrednost prave umetnine je utemeljena $\mathrm{v}$ ritualu, $\mathrm{v}$ katerem je imela svojo izvirno in prvotno uporabno vrednost (Benjamin 2003, 154). Mnogi artefakti, kot so na primer knjige, kipi, medalje ipd., so v osnovi narejeni kot premični predmeti, drugi artefakti, ki pa so nepremični oziroma namenjeni za $\mathrm{v}$ točno določen prostor, pomen in vrednost dobivajo iz okolice. Če se ta spremeni, izgubijo kontekst in ambient prikrajšajo za svojo prisotnost. Nekatere artefakte so premaknili zaradi spremembe okolice (tempelj v Aswanu), druge zaradi vojne, kraje ali nesreč. Nekateri se lahko vrnejo, drugi so še vedno na tujem. Odstranitev v nekaterih primerih postane življenjskega pomena za njihovo historično reševanje (Lowenthal 2015, 444). Taka odstranjevanja pa imajo posledice: premik spomenikov uniči njihovo pričevanjsko vrednost in povezava $s$ krajem izvora je mnogokrat izbrisana. Veliko relikvij je danes dostopnih $\mathrm{v}$ muzejih ali galerijah in jih v prvotni katedrali ali oddaljenem gradu ne najdemo več. Če umestitev relikvije med štiri stene pomeni lažji dostop do njih, jim to sočasno odvzame časovno zavedanje, ki ga ne more popraviti niti bližina kraju izvora niti najbolj inovativna in dovršena postavitev (Lowenthal 2015, 448). Opravka imamo s spolzkim področjem, saj je dediščina del preteklosti, s katerim se zelo enostavno manipulira.
$\mathrm{V}$ članku predstavljeni historiat nam osvetljuje pomen restitucije umetnin za Slovenijo in Italijo, poleg tega pa razkriva še mnogo nerešenih vprašanj, predvsem pa političnih ozadij, ki niso bila še ustrezno obravnavana. Primer kliče po kontekstualizaciji predvsem dejstva, da so nekatere rane iz polpretekle zgodovine še odprte. Pomen restitucije umetnin se ne nanaša samo na umetnostno zgodovino, ki ima nalogo raziskati avtorstvo in provenienco odtujenih umetnin, ampak tudi na zgodovinski, družbeni ter politični kontekst, saj je dediščina učinkovito orodje za politično manipulacijo in apropriacijo (tako kulturno kot ozemeljsko). Od sprejetja ICOMOS-ove Beneške listine (1964) dalje (Doktrina I Mednarodne listine ICOMOS 2003, 26), se dediščina varuje $\mathrm{v}$ kontekstu. Vprašanje, ki si ga moramo ob tem postaviti, pa je: Kaj se zgodi v primeru, ko je kontekst sporen? Komu pripada ta dediščina? Dediščinske študije ta problem jasno artikulirajo:

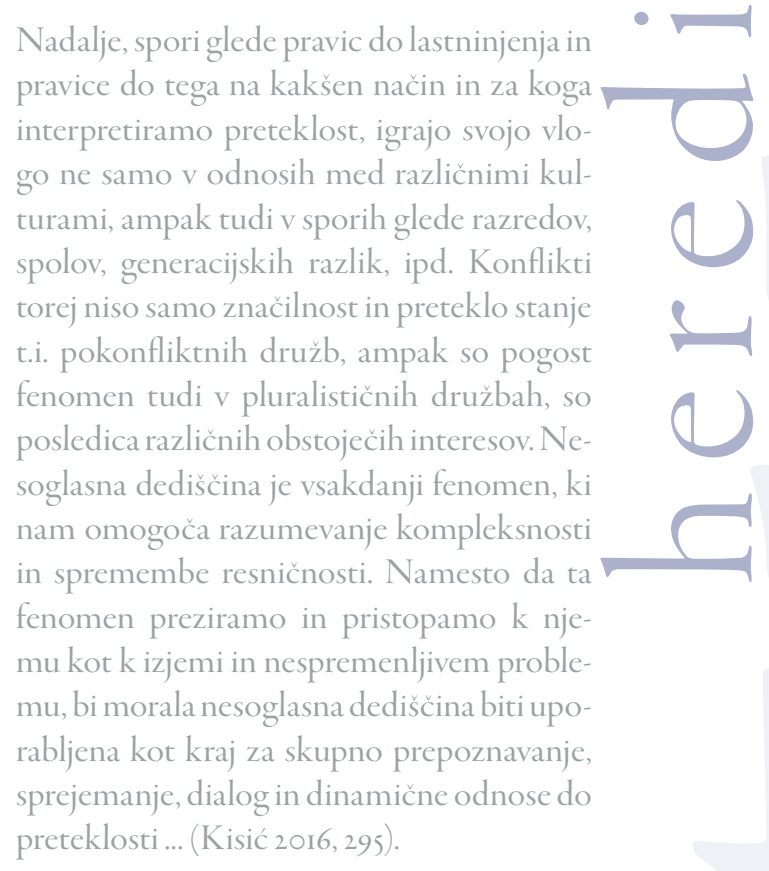

Socialni konstrukti preteklosti so ključni elementi v procesu dominacije, podrejanja in odpora (Silverman 20II, 3). Niso samo ljudje tisti, ki želijo vrnitev in/ali nadzor nad svojo dediščino, tudi države si to želijo in zanimati nas mora, 
zakaj in kako so ti objekti dediščine manipulirani skozi diskurz (Silverman 20II, I4). Ko ljudje definirajo idejo vključevanja in izključevanja, se sklicujejo na povezanost $\mathrm{s}$ krajem oziroma vsaj z reprezentacijo kraja, to pa uporabijo za legitimacijo svojih zahtev po teritoriju (Ashworth in soavtorji 2007,5$)$. Dediščina je sestavljena iz različnih preteklih dogodkov, osebnosti, spominov, mitologij, fizičnih relikvij in krajev, s katerimi je simbolično povezana (Ashworth in soavtorji 2007,40 ). Dediščina je tudi politični proces, $v$ katerem so določeni kraji vključeni v dogovorjen nacionalni pogled na svet, medtem ko so drugi zanikani ali namensko prezrti, ker predstavljajo grožnjo dogovorjeni nacionalni podobi (Knapp in Antoniadou 1998, 33). Današnje razumevanje identitete kot mnogovrstnost lastnin, in potrebe posameznikov do pripadnosti teritorialno določeni družbeni skupini, ni nič manj pomembna kot takrat, ko so se definirale nacionalne države i9. stoletja. Razlika je le v tem, da so identifikacije $\mathrm{z}$ reprezentacijo prostora in kraja postale kompleksnejše, ker globalizacijo spremlja reteritorializacija, ki privilegira regionalno in lokalno na račun nacionalnega (Ashworth in soavtorji 2007, I). Preučevanje dediščine se ne nanaša neposredno na preučevanje preteklosti, ampak na vsebino, interpretacijo in reprezentacijo dediščinskih diskurzov ter na to, kako so izbrani glede na povpraševanje sedanjosti. Pomen je tisti, ki daje vrednost dediščini (Ashworth in soavtorji 2007, 3). Dediščina je socialni konstrukt, ki ga oblikujejo politični, ekonomski in družbeni vplivi sedanjosti. Dediščinski konflikt je postal globalni problem, ker je tako prepleten s procesom družbenega vključevanja in izključevanja, da definira družbene karakteristike z vedno bolj kompleksnimi formami kulturne drugačnosti (Ashworth in soavtorji 2007, 4).

\section{Zgodovinski okvir}

Zgodovinski okvir obravnavanega primera je izredno kompleksen in vreden posebne obravnave, zato sem se odločila, da se osredotočim izključno na nekaj najpomembnejših zgodovinskih prelomnic (za več glej Pirjevec 2007), na katerih slo- ni razlaga v nadaljevanju. Obalna mesta so bila od svojega osnovanja vezana na romanski svet ob severnem Jadranu (med I3. in I8. st. primarno na takratno oblastno strukturo Beneške republike iz. Serenissime), obenem pa v stalnem stiku s slovanskim svetu v mestnem zaledju. Avstrijska oblast v i9. stoletju je večkulturnost še spodbujala. A prav večkulturni značaj regije se je z oblikovanjem nacionalnih držav izkazal za odlično odskočno desko za utemeljevanje ozemeljskih apetitov. Prvo svetovno vojno je dokončno zaključila Rapalska pogodba, podpisana leta 1920 , ki je na novo zarisala mejo med kraljevinama (Italija in SHS) in današnja pokrajina Primorske je pripadla Italiji (Pirjevec 2008, 107-I09). Obdobje med obema vojnama je zaznamoval fašizem in strmoglavljenje slovensko-italijanskih odnosov med prebivalstvom. Po nastopu druge svetovne vojne je v začetku aprila i94I Italija s pomočjo Nemčije in Madžarske napadla Kraljevino Jugoslavijo (Gombač 1996, 8I). Koncu druge svetovne vojne (1945) je sledilo dolgotrajno določanje novih državnih meja. Devetega junija I945 sta generala Arso Milovanović in William D. Morgan podpisala $\mathrm{v}$ Beogradu sporazum, ki je bil povsem v sozvočju zahtevami takratnega ameriškega predsednika Trumana. Jugoslovanske enote naj bi se umaknile iz Trsta, Gorice in drugih območij zahodnega dela Julijske krajine, za t.i. Morganovo črto (Pirjevec 2007, 315). Dvanajstega junija 1945 so se morale jugoslovanske enote, $\mathrm{v}$ skladu s sporazumom iz Beograda, umakniti za demarkacijsko linijo. Obsežno obmejno sporno ozemlje Julijske krajine je bilo razdeljeno na dve okupacijski coni, A in B, od katerih je v pričakovanju dokončne razmejitve na mirovni konferenci prva prišla pod anglo-ameriško, druga pod jugoslovansko vojaško upravo. (Pirjevec 2007, 3I8). Na Pariški konferenci leta 1947 je bila usoda večine spornega ozemlja dorečena, ostalo pa je odprto vprašanje pripadnosti Trsta in njegovega neposrednega zaledja, od Devina do Novigrada. Oblikovana je bila začasna tamponska državica Svobodno tržaško ozemlje (STO) oz. Territorio Libero di Trieste (TLT), ki je imela lasten statut, po katerem je bila država tudi uradno večjezič- 
na. Tudi ta politična tvorba je bila razdeljena $\mathrm{v}$ dve coni in ločeni upravi: cono A, ki je obsegala Trst z okoliškimi vasmi na kraškem robu, je upravljala $Z_{V U^{2}}$; cono $\mathrm{B}$, ki jo obsegala območje od Ankarana do Novigrada, pa je upravljala VUJA ${ }^{3}$ (Poročilo SIZKK 2000, I3; Pirjevec 2007, 368, 374). Po večletnih pogajanjih in skorajšnjem ponovnem spopadu (1953) je bilo tržaško vprašanje razrešeno, posledično pa določena meja med Italijo in Jugoslavijo (in torej med demokratično-kapitalističnim Zahodom ter socialističnim Vzhodom). Z Londonskim sporazumom (oktobra 1954) je cona A pripadla Italiji, cona B pa Jugoslaviji (Pirjevec 2007, 478).

\section{Usoda umetnin iz Kopra, Izole in Pirana pred, med in po vojni}

O usodi artefaktov iz Kopra, Izole in Pirana pred, med in po vojni pišeta zlasti dve avtorici: Sonja Ana Hoyer in Irene Spada. Obe se sklicujeta predvsem na dnevnik honorarnega inšpektorja in direktorja evakuacije umetnin in zaščite umetniškega patrimonija Vidma z okolico, Carla Someda de Marca, ter ostale dosegljive arhivske vire. Zaradi tega se v nadaljevanju sklicujem predvsem nanju, saj sta edini, ki se ukvarjata specifično z odtujenimi artefakti na območju obalnih mest s širšo okolico.

\section{Pred drugo svetovno vojno}

Že po prvi svetovni vojni je italijansko ministrstvo za javno izobraževanje vpeljalo merila za reševanje in ohranjanje umetniške dediščine v primeru oboroženega spopada. Pomembna osebnost, zadolžena za varovanje dediščine, je bil nadzornik Ferdinando Forlati, arhitekt na Nadzorništvu v Benetkah (Spada 2017, 19I). V pismu, poslanem 7. januarja I93I na Direzione generale antichità e belle arti, je takratni nadzornik v Trstu Forlati spisal po njegovem mnenju uporabne nasvete za varovanje nacionalnega umetniškega zakladja pred letalskimi napadi. Predlagal je dve možnosti: direktno obrambo in prenos umetnin na varne kraje. $\mathrm{V}$ pismu je omenjal, da mu

\footnotetext{
Zavezniška vojaška uprava
}

Vojaška uprava Jugoslovanske armade je največ skrbi povzročalo dejstvo, da se je večina umetnin $\mathrm{v}$ njegovi pristojnosti nahajala $\mathrm{v} \mathrm{ob}-$ mejnih okrajih (Spada 2017, 192). Februarja 1932 je ponovno poslal pismo, $v$ katerem je spraševal o napredku glede očuvanja kulturne dediščine pred letalskimi napadi. Takrat je Forlati pripravljal seznam umetnin degni di particolare interesse (posebnega zanimanja) (Forlati 1932 v Spada 2017,193$)$ in seznam pomembnejših stavb. $\mathrm{Na}$ prvi verziji poslanega seznama ni bilo zabeležene Istre (Spada 2017, 193). Italijanski kralj Vittorio Emanuele III je 5. marca I934 odobril prvi dekret za zaščito teritorija in civilnega prebivalstva pred letalskimi napadi Regolamento per la protezione antiaerea del territorio nazionale e della popolazione civile (Uredba za očuvanje pred letalskimi napadi nacionalnega teritorija in civilnega prebivalstva), ki je vseboval odlok o ustanovitvi instituta občinskih in provincialnih odborov za obrambo pred letalskimi napadi (Spada 2017, 195). Ministrstvo za vojno se je odločilo, da brez njihove odobritve nadzorniki niso imeli prostih rok glede ukrepov za očuvanje dediščine (Spada 2017, 196). Januarja 1935 so bili narejeni seznami, vključno z oceno stroškov v primeru premikanja in zaščite umetnin. Forlati ${ }^{4}$ ni verjel, da so obmejni kraji varni za zbiranje umetnin in je bil mnenja, da bi umetnine morali premestiti v Veneto (Spada 2017, 198). Prvi predlog varne lokacije, ki ga je ponudil nadzornik Gino Fogolari, je bil frančiškanski samostan Carceri, sedem kilometrov oddaljen od kraja Este. Zanj se niso odločili, saj je bila stavba v statično slabem stanju (Spada 2017, 199). Predlagane so bile tudi druge lokacije, ki pa se niso uveljavile. Prvi seznam, ki ga je sestavila Regia Soprintendenza alle opere d'antichità e d'arte di Trieste (Nadzorništvo za starine in umetnine iz Trsta), je prišel na Direzione generale antichità e belle arti 21. marca 1935 (Spada 2017, 200). Na seznamu so bile premičnine razdeljene po provincah. Poleg tega so bile na seznamu tudi manjše stvari, za katere so menili, da bi se jih dalo zlahka odtujiti. V primerjavi s se-

4 Konec leta 1935 so Forlatija premestili v Benetke, v Trstu pa ga je nasledil Giovanni Brusin, vendar samo do konca leta 1936, ko ga je zamenjal Bruno Molajoli. Bruna Molajolija je v Trstu kasneje zamenjal Fausto Franco (Spada 2017, 210). 
znami za očuvanje iz prve svetovne vojne so bile na tokratnih seznamih tudi umetnine iz zasebnih rok. Ministrstvo za nacionalno izobraževanje je po Ministrstvu za vojno obvestilo Nadzorništvo, da mora v primeru vojne ohraniti sedež v Trstu (Spada 2017, 20I). Januarja 1936 je Brusin poslal na Direzione generale provizorični seznam umetnin v zasebni lasti, saj naj v danem trenutku ne bi bilo mogoče narediti dokončnega (Spada 2017, 202). Na dopolnjenem seznamu, poslanem februarja 1936, je navedel Koper in Pulo kot kraja, kjer bi se umetnine lahko zbirale (Spada 2017, 202). Koper in Pula sta bila zapisana kot zbirna centra, kjer naj bi se umetnine dokončno zapakiralo in od tam odpeljalo na varno na naknadno določeno lokacijo. V Bolletino d'arte, ki ga je izdalo Ministrstvo za nacionalno izobraževanje aprila 1938, je minister za nacionalno izobraževanje Giuseppe Bottai jasno izrazil svoj namen, $\mathrm{da}$ bo zaščitil umetnine $\mathrm{v}$ sklopu nacionalnega teritorija, hkrati pa je odločno zavrgel idejo profesorja Alberta Geouffreja De La Pradelle, ki je predlagal, da se umetnine premestijo na ozemlje nevtralnih držav (Spada 2017, 209). Premik v nevtralne države po njegovem mnenju ne bi jamčil večje varnosti, ravno obratno. Bal se je, da jih v primeru, če bi Italija vojno izgubila, ne bi nikdar več dobili nazaj (Spada 2017, 210).

\section{Med drugo svetovno vojno}

Italija je stopila v vojno ıo. julija I940. Poudariti je treba, da umetnine iz Kopra, Izole in Pirana niso bile nikdar odpeljane kot vojni plen niti jih niso premestili takratni prebivalci, temveč sta njihov umik z obmejnega področja zaradi zavarovanja pred vojnim uničenjem narekovala italijanska zakona I089 (I. junij 1939) in I04I (6. julij 1940) Protezione delle cose d'interesse artistico, storico, bibliografico e culturale della Nazione in caso di guerra (Hoyer 2005, 15; Spada 2017, 211). Med letoma 1939 in 1940 je bilo veliko število umetnin odpeljanih na varno, posebno iz Istre, saj so te kraje zaradi dogodkov iz prejšnje vojne dojemali kot izredno rizične (Casadio in Castellani 2005, 29). Za vso potrebno logistiko za umik del je poskrbela pristojna spomeniškovarstvena služba, t. i. Nadzorništvo v Trstu (Hoyer 2005, I5). Zbiranje in odvoz umetnin so izpeljali v dveh tednih junija 1940. Ta dogodek je vodil tržaški spomeniškovarstveni nadzornik Fausto Franco. Umetnine so shranili v vili zadnjega beneškega doža Manina v Furlaniji. Dela so zapakirali v zaboje, priskrbelo jih je podjetje za prevoze Exner iz Trsta, ki je skupaj s podjetjem Roiatti iz Vidma izpeljala logistiko prevoza (Spada 2017, 212; Hoyer 2005, I5). Prvotna lokacija, ki je bila predvidena, je bila Rocca Bernarda v Gorici, ker pa je bila poleg smodnišnica, so se raje odločili za Vilo Manin, ki jo je dal v uporabo grof Leonardo (Magani 2005, 33; Spada 2017, 212).

$\mathrm{Na}$ seznamih Nadzorništva, poslanih na Ministrstvo, so našteti sodelavci, ki so sodelovali pri evakuaciji. Na teh seznamih je tudi Koper, kjer so sodelovali Antonio Pozzar, odgovoren za občinsko dediščino, pater Pasquale Giorgio Salico, odgovoren za samostan sv. Ane, in monsinjor Sirotti, odgovoren za stolnico. V Piranu je bil odgovoren Mario Bartoli za občino, pater Lino Biasi za sv. Frančiška in monsinjor Egidio Malusà za cerkve sv. Jurija, sv. Marije in sv. Štefana (Spada 2017, 213). V Vili Manin je bilo shranjenih 380 zabojev z umetninami s celotnega območja Julijske krajine in Furlanije. Vsak zaboj je bil inventariziran s svojo številko; vsaka slika je imela svoj uradni dokument, podpis, pečat in datum; vsak dokument (ki je potrjeval umik del zaradi zaščite pred letalskim bombardiranjem) je bil izdan v treh izvodih: enega je prejel lastnik, enega Nadzorništvo v Trstu in enega izbrani prevoznik umetnin Exner iz Trsta. Najbolj natančen opis umetnin in podatke o zabojih najdemo $\mathrm{v}$ dnevniku honorarnega inšpektorja in direktorja evakuacije umetnin in zaščite umetniškega patrimonija Vidma z okolico, Carla Someda de Marca, ki je dnevnik vodil med ıo. aprilom 1940 in 21. majem 1945 (Spada 2017, 21I, Hoyer 2005, I5). Prva pošiljka umetnin iz Istre je prišla 20. junija $1940 \mathrm{z}$ vlakom. V dnevniku je zabeleženo, da so prejeli naslednje zaboje iz Kopra in Pirana: sedem iz koprskega muzeja, enega iz stolne cerkve Marijinega vnebovzetja v Kopru, štiri iz samostana sv. Ane v Kopru, enega iz cerkve Ma- 
rije Tolažnice v Piranu, enega iz cerkve sv. Štefana v Piranu, štiri iz piranske Občinske palače, pet iz cerkve sv. Jurija v Piranu (Spada 2017, 214).

Petindvajsetega junija 1940 je prispel še en zaboj iz sv. Ane, tako da jih je bilo skupaj pet (Spada 2017, 214). Sonja Ana Hoyer navaja tudi zaboj iz cerkve sv. Frančiška v Piranu, ki pa ga Irene Spada ne omenja (Hoyer 2005, 16, Spada 2017, 214). Someda je v dnevniku zapisal, da ga je zelo skrbela bližina Jugoslavije (Spada 2017, 213). Franco je v istem mesecu razposlal okrožnico $s$ prošnjo za inšpektorje in direktorje muzejev in ostale, ki so se ukvarjali z evakuacijo, da se k zabojem priloži negative $\mathrm{z}$ dokumentiranimi deli in zapisom, ki pojasnjuje vsebino zabojev (Spada 2017, 214). V Vili Manin je začelo zmanjkovati prostora in Someda je moral prositi grofa Manina za dodatne prostore (Spada 2017, 218). Z napredovanjem vojne so se odločili, da zaboje premaknejo v notranjost dežele, dlje od nevarnih vzhodnih meja Italije. To se je izkazalo za zelo težko nalogo, saj so bili premiki zaradi vojnega stanja s prevoznimi sredstvi zelo omejeni (Spada 2017, 219). Že leta 1942 je Someda izrazil zaskrbljenost, saj Ministrstvo ni odobrilo povečanja števila oboroženih stražarjev (Spada 2017, 22I). Leto kasneje v dnevniku navaja, da se je Francu zdelo vedno bolj nevarno imeti umetniška dela v enem samem kraju. Tudi sam Someda je razmišljal o tem, da bi dela razpršili (Spada 2017, 22I). Zaradi nevarnosti in strahu pred tem, da bodo odšli tudi vojaki, sta najela civilno stražo osmih oseb (Spada 2017, 222). Someda je poslal okrožnico lastnikom umetnin, v kateri je pisalo, da obstaja nevarnost poškodb in kraje. Pojasnil je, da imajo, če želijo svojo zasebno lastnino nazaj, na izbiro dve možnosti: lahko pridejo ponjo na lastne stroške ali jo še naprej prepustijo $v$ očuvanje njim, $s$ tem da $\mathrm{v}$ primeru poškodb zanje niso odgovorni. Vsi lastniki niso prišli po umetnine, zato so del zabojev iz Pule in del iz Pirana zaradi onemogočene vrnitve na kraj izvora preselili v videmski muzej (Spada 2017, 222). Nato je jeseni 1943 prišlo do Nemške okupacije Italije. Ustanovljeno je bilo območje OZAK (Operationszone Adriatisches Küstenland / Operacijska cona Jadran- sko Primorje). Odgovoren za umetnine je bil dr. Walter Frodl, direktor celovškega muzeja, ki je nemudoma začel sodelovanje s Somedo. Novembra 1943 se je Nadzorništvo odločilo, da razpusti center v Passarianu in da dela preselijo v San Daniele del Friuli (Spada 2017, 225; Hoyer 2005, 15). Soglasja z nemške strani niso dobili in tudi podjetje Roiatti, ki je pomagalo pri prvi selitvi, se je zaradi strahu, da bi jim zaplenili vozila, odreklo sodelovanju (Spada 2017, 225). Novembra jim je umetnine uspelo preseliti na skrito lokacijo $\mathrm{v}$ San Daniele (Spada 2017, 226). Tiste, ki so jih vrnili na izvorna mesta, pa so doživljale raznoliko usodo. Carpaccieva slika Marija $z$ otrokom in svetniki iz cerkve sv. Frančiška v Piranu, na primer, ni bila vrnjena minoritom v Piran, temveč umeščena na sedež redovne province $\mathrm{v}$ Padovo. Podobno naj bi se zgodilo s poliptihom Cime da Conegliana Marija zotrokom in svetniki, ki je bil leta 1943 sicer vrnjen v Koper, vendar ga je leta 1946 neidentificirani menih odnesel $v$ samostan S. Francesco della Vigna v Benetkah, od tam pa naj bi bil leta 1966 premeščen v Mantovo (Hoyer 2005, 16). Dela niso bila nikdar vrnjena na izvorna mesta, delno tudi zaradi nastanka nove meje med Italijo in Slovenijo, uveljavljene z Mirovno pogodbo z Italijo leta 1947 in Londonskim memorandumom leta 1954 (Hoyer 2005, 17).

\section{Primersv. Ane}

Artefakti iz sv. Ane so doživljali drugačno usodo. Poudariti velja, da je bil lastnik umetnin frančiškanski red in ne država, kot npr. pri umetninah, odpeljanih iz koprskega muzeja. Zaradi tega so se umetnine tudi po kapitulaciji Italije še vedno premikale iz države v državo, saj je bil frančiškanski red prisoten tako na področju Jugoslavije kot tudi v Italiji. Najbolj odmeven je primer poliptiha Cime da Conegliana, ki se je nahajal v samostanu sv. Ane. Leta 1940 so ga odpeljali na varno v Vilo Manin. Nazaj v sv. Ano naj bi prišel 5. novembra 1943 (Algeri in L'Occaso 2005,88 , Hoyer 2005,16 ), vendar obstaja sum, da je poliptih Cime da Conegliana že leta 1942 ali 1943 prišel v Trst, kamor so se v samostan Santa Maria Maggiore zatekli frančiškani (Alge- 
ri in L'Occaso 2005, 88, Spada 2017, 228). Kasneje, leta 1946 ali 1947 , naj bi ga skupaj z okvirjem italijanski patri odnesli v San Francesco della Vigna v Benetke (Algeri in L'Occaso 2005, 88, Hoyer 2005, 16). Ostalim umetninam iz sv. Ane naj bi se pridružil šele leta 1965 , ko so vse artefakte preselili v Mantovo (Algeri in L'Occaso 2005, 88). Umetniška dela so najverjetneje premikali v okviru današnjih meja Italije šele, ko se je vojna bližala koncu. Dela danes hranijo v beneški provinci ordinariata frančiškanov in se trenutno nahajajo v Gemoni (Spada 2017, 229). Irene Spada $\mathrm{v}$ knjigi navaja pismo poslano marca 1944, v katerem so frančiškani iz sv. Ane prosili Nadzorništvo za dobrodelni prispevek 20.000 lir, ki bi pokril del stroškov, porabljenih za izgradnjo zaklonišča pred letalskimi napadi, kamor so spravili umetnine. Da bi Fausta Franca prepričali, kako varno je njihovo zaklonišče, so mu poslali seznam vseh hranjenih umetnin, da bi s tem poudarili njihovo vrednost:

I. Ancona di Cima da Conegliano: deset slik z okvirji Vittoria da Feltre (šest zabojev),

2. Oltarna podoba $V$ imenu Jezusa: Benedetto Carpaccio, en zaboj,

3. oltarna podoba Snemanje križa: Girolamo di Santa Croce, en zaboj,

4. slika Križanje in svetniki: Palma il Giovane, en zaboj,

5. slika Madona na prestolu in Sante del Catena, en zaboj,

6. slika Sveti Bernardin iz Siene: Sano di Pietro, en zaboj,

7. dve sliki sv. Joahim in sv. Ana: Girolamo da Santa Croce, en zaboj,

8. manjša dela (Spada 2017, 227).

Bibliografski material:

I. pet vesperalov iz is. stoletja,

2. sedem gradualov iz I5. stoletja,

3. dva latinska kodeksa T. Livii Historiae in Sermones,

4. dva grška kodeksa Isocrates ad Daemonicum in Lexicon Graecum,
5. 5 I inkunabul (Spada 2017, 227).

\section{Drugo povojno obdobje (I945-I954)}

Jugoslovanski Prosvetni odsek okrožnega narodnoosvobodilnega odbora za Tržaško okrožje (NOO) je že I5. maja 1945 okrajnim referentom odredil popis škode na dediščini. Ker je bil od leta 1947 Koper pod okriljem cone B STO, je zanje veljal odlok št. 22., ki ga je 29. maja 1945 izdal Primorski narodnoosvobodilni odbor (PNOO) za slovensko Primorje in Trst (Rogoznica 2015, 243). Odlok je bil izdan v obdobju jugoslovanske vojaške prisotnosti v Trstu. Podobno kot odlok št. I9 o zaščiti knjižnic, arhivov in kulturnih spomenikov, ki ga je januarja 1945 objavilo Predsedstvo Slovenskega narodnoosvobodilnega boja (SNOS), je tudi odlok PNOO postavljal pod zaščito naravoslovne, umetniške in druge predmete kulturne in zgodovinske vrednosti $\mathrm{v}$ privatni in javni lasti. Določal je, da morajo navedeni predmeti biti ohranjeni na mestu, kjer so izvorno stali. Uničevanje, poškodovanje, premeščanje, prodaja in druge oblike odtujevanja so bile prepovedane $s$ kazenskim pregonom. Odlok PNOO za razliko od odloka SNOS ni zagotavljal institucionalne spomeniške zaščite, saj ni navajal konkretnih organov, ki bi bili odgovorni za nadzor in zaščito spomenikov, niti ni opredeljeval pogojev njihovega upravljanja. V Pariški mirovni pogodbi z Italijo (1947) je pisalo, da mora Italija vrniti Jugoslaviji premoženje in arhivsko gradivo, ki je bilo odneseno z območja, okupiranega leta 194I (Žitko 2005, 3I). Odlok je do leta 1953 predstavljal edini pravni predpis, ki je urejal spomeniško varstvo in zaščito kulturnih spomenikov na območju cone B STO (Rogoznica 2015, 244). Za izdelavo seznamov odnesenih ali uničenih predmetov kulturne dediščine iz koprskega območja je bil odgovoren okrajni referent za prosveto. Tako je oktobra 1945 Karlo Prijon, referent pri OLO (Okrajni ljudski odbor) Koper, sestavil splošni seznam rokopisov in knjig koprske mestne knjižnice, ki so bili odneseni v Benetke. Na seznamu je kot manjkajoče gradivo navajal: knjige koprske komune, zgodovinske spise srednjega veka, občinske akte, doku- 
mente občinske uprave, rokopise, pergamente in razne dokumente, med njimi zakonik iz is. stoletja in originalne statute Kopra, rokopise družine Carli, akte iz obdobja francoske oblasti v Kopru, akte iz obdobja prve avstrijske oblasti v Kopru, dokumente in pisma iz obdobja italijanskega risorgimenta (preporod naroda) in drugo. Vrednost odnesenega je bila izredno velika. Prijon je že istega leta predlagal zahtevek po restituciji odpeljanega gradiva (Rogoznica 2015, 245).

$\mathrm{V}$ začetku petdesetih let je bilo zaradi nove politične ureditve vprašanje spomeniškega varstva potisnjeno v ozadje oziroma podrejeno političnim vprašanjem. Kmalu po zaključku vojne so bili v vsaki republiki tedanje Jugoslavije organizirani okrožni zbirni centri (ZC) za kulturnozgodovinske predmete (Rogoznica 2015, 246). V Sloveniji so bili centri v Mariboru, Celju, Novem mestu, osrednji federalni zbirni center pa se je nahajal v Ljubljani. Vojaška uprava jugoslovanske armade (VUJA) je kot najvišji oblastni organ za področje cone B STO v vprašanja spomeniškega varstva intervenirala le v redkih konkretnih primerih na osnovi zahtev jugoslovanske oblasti ali mednarodnih pritiskov, zadolžitev za reševanje varstvenih in spomeniških vprašanj pa je bila dana odseku za prosveto, delujočem pri IOLO (Istrski Okrajni ljudski odbor) (Rogoznica 2015, 247). Potem, ko je novembra 1949 po službeni dolžnosti koprski okraj obiskal konservator Zavoda za zaščito in znanstveno proučevanje kulturnih spomenikov in prirodnih znamenitosti Slovenije Ciril Velepič, je republiški zavod od sveta za prosveto in kulturo IOLO zahteval čimprejšnjo organizacijo in vzpostavitev službe za spomeniško varstvo ter pregled in inventarizacijo kulturnih spomenikov koprskega okraja (Rogoznica 2015, 249., Žitko 2005, 31). Nemudoma je ugotovil, da je bilo odnesenih veliko predmetov (Žitko 2005, 3I).

V okviru okrožnega sveta za prosveto in kulturo sta bila leta 1950 oblikovana dva odbora: odbor za šolstvo in odbor za znanost in kulturo. V okviru slednjega je bila ustanovljena posebna komisija za pregled kulturnih spomenikov, katere člani so bili: Roman Savnik, Jurij Jan in Srečko
Vilhar. Komisija je opravljala preglede knjižnic, arhivov in ostalih zgodovinskih spomenikov $\mathrm{v}$ coni B STO. Večkrat je tudi intervenirala in izdala nekatere odloke $\mathrm{z}$ namenom zaščite knjižnega in arhivskega gradiva ter drugih kulturnih spomenikov (Rogoznica 2015, 249). Ko je bilo zaradi zaostritve političnih razmer maja 1952 ukinjeno Istrsko okrožje (IOLO) in so bile njegove pristojnosti prenesene na OLO Koper in Buje, se je na območju cone B STO začela širiti jugoslovanska zakonodaja (Rogoznica 2015, 25I). Ob začetku leta 1953 je bil na področju okraja Koper uveden Zakon o varstvu kulturnih spomenikov in prirodnih znamenitosti LRS iz leta 1948 (Rogoznica 2015, 25I; Žitko 2005, 3I). V prvi polovici istega leta je bila v Kopru ustanovljena komisija za pregled knjig in umetnin, ki jo je vodil Miroslav Pahor. Do leta 1954 sta v njej sodelovala tudi Srečko Vilhar in Emil Smole (Rogoznica 2015, 25I).

\section{Obdobje po prikljucitvi cone B Jugoslaviji (I954-I9gI)}

\section{Restitucija v širšem kontekstu}

Problematika restitucije umetnin je tako na Slovenskem kot drugod že nekaj desetletij pereč problem. Že od poznega i8. stoletja so velike imperialne velesile pričele zbirati antikvitete z osvojenih teritorijev: partenonski okras, asirski levi in reliefi iz Korsabada, H amurabijev zakonik, skulpture iz mavzoleja iz Halikarnasa, ipd. (Renfrew 2000, I8). Med najbolj odmevnimi sta tudi kamen iz Rozete, ki se je po vojni med Francozi in Britanci znašel v Britanskem muzeju (Ikram 20II, I45), ter busta Nefretete v berlinskem Egipčanskem muzeju. (Ikram 20II, I47). Omenjeni primeri so javnosti najbolj poznani, a predstavljajo le manjšino nerešenih primerov restitucije artefaktov. Navedeni primeri nimajo veliko skupnega s primerom v pričujočem prispevku. Če pa se osredotočimo na čas in geografski kontekst, primerljivo usodo kot pri odtujenih umetninah iz obalnih mest, odkrijemo v usodi zadarskega zaklada, o katerem piše Antonija Mlikota. Primer je seveda zanimiv, saj časovno in regionalno sovpada s primerom odtuje- 
nih umetnin iz Istre, vendar je potek dogodkov po vojni v tem primeru nekoliko drugačen. Njena raziskava temelji na arhivu Robertsove komisije, ki je pod okriljem ameriške vojske uradno delovala med leti 194I in 1946 (Mlikota 2012, 24I). Uradni naziv komisije je bil Comission for the Protection and Salvage of Artistic and Historic Monuments in Europe (Mlikota 2012, 242), dobila pa je ime na prvem sestanku ki ga je vodil sodnik vrhovnega sodišča Owen J. Roberts, po katerem je skupina dobila ime. Komisija se je povezala $\mathrm{z}$ lokalnim prebivalstvom in poznavalci, ter že na začetku vojne izdelala baze podatkov o umetniških spomenikih v nevarnosti. Izdelali so približno 700 zemljevidov, na katerih so bili označeni objekti kulturnega in historičnega pomena, ki bi utegnili biti ogroženi. Priročniki, izdelani za vsako državo posebej, so imeli poleg zemljevidov tudi sezname pomembnejših del kulturne dediščine (Mlikota 20I2, 246). Tako Zadar kot tudi Koper, Izola in Piran so na seznamih beleženi kot mesta italijanske države. Ti seznami naj bi predstavljali nekakšno prvo pomoč za prepoznavanje in zaščito na terenu. Primarna funkcija komisije (njene člane so običajni vojaki imenovali Monuments Man) je bila svetovanje ameriški vojski pri načrtovanju vojnega delovanja tako, da bi se kar se da dobro zaščitile kulturne dobrine (Mlikota 20I2, 247). Vojno osebje in člani MFAA so morali na terenu prepoznati in zaščititi kulturne spomenike in evidentirati ter vračati ukradeno, sekundarna naloga pa je bila poiskati način za vračilo ukradenega (Mlikota 20I2, 247). Dokumentarno gradivo pokriva tudi področje bivše Jugoslavije (Mlikota 20I2, 249). Edine informacije, ki jih je imela MFAA o umetninah iz Zadra, so prišle od dr. Mercurellija, nekdanjega asistenta za antikvitete in profesorja Luigija Creme (Mlikota 20I2, 255). Luigi Crema nosi velike zasluge za rešitev zadrskih umetnin, saj je namestil zaboje z ogroženimi umetninami v zvonik sv. Marije (Mlikota 20ı2, 256). Njegov asistent dr. Mercurelli, ki je zadnji ostal v Zadru, je obljubil, da bo MFAA poslal podrobno poročilo o umetninah, ki so bile odtujene, vendar je nepričakovano preminil (Mlikota 2012, 259). Po njegovi smrti je profesor Galli iz Ancone napisal poročilo o šestih zabojih iz Zadra, ki so prispeli $\mathrm{k}$ njim in bili pred tem zakopani pod kripto sv. Cirijaka (Mlikota 20I2, 260). V poročilu decembra I 944 piše, da je bilo teh šest zabojev del večjega tovora (I zabojev) iz Zadra in da so najverjetneje ostali zaboji v Benetkah. Zaboji so vsebovali različne najdbe iz dveh liburnijskih grobov iz Nina, najdbe rimskih grobov iz Zadra, beneške in grške kovance, rimski nakit in rimske geme, slike in razpela (Mlikota 2012, 260). V poročilu Fausta Franca o prenosu zabojev $\mathrm{z}$ umetninami iz Zadra v Benetke piše o I 4 zabojih, ki so prišli iz cerkve sv. Donata v Trst (Mlikota 20I2, 26I). Zaboje so iz Trsta preselili v doževo palačo v Benetke ı. julija 1944 (Mlikota 20ı2, 265). Sočasno so premestili tudi I 49 zabojev arhivskih dokumentov iz Zadra v Benetke. Operacija Zara, ki jo je vodila MFAA se je začela 28 . avgusta 1945 zjutraj $\mathrm{v}$ prostorih doževe palače $\mathrm{v}$ Benetkah (Mlikota 20I2, 267). Operacija Zara je vojaški dokument, ki razlaga okoliščine dogodkov in opisuje stanje predmetov kulturne dediščine iz Zadra. Komisija je posnela in katalogizirala celoten inventar iz šestih zabojev, ki so bili zakopani pod kripto. Opaziti je bilo, da je v škatli za bilo šest kosov namesto navedenih 75 iz prvotnega seznama iz leta 1940 (Mlikota 2012, 269). Vsak predmet so popisali in inventarizirali, če ga niso prepoznali, pa so ga podrobno opisali. Zaboje so spet zapečatili 9. septembra 1945. Namenjeni so bili nazaj v Zadar, vendar tja niso nikdar prispeli (Mlikota 2012, 270). Jugoslovanski minister za izobraževanje je v Istro leta 1947 poslal konservatorja Ljuba Karamana, da bi zbral vso dokumentacijo o predmetih kulturne dediščine, ki so bili prepeljani v Italijo. V njegovem priročniku piše, da so bili predmeti kulturne dediščine prepeljani v Benetke, kar je potrjevalo zgodbo nekdanjih zaposlenih v zadrskih kulturnih institucijah (Mlikota 20I2, 27I). Stirinajst zabojev je bilo aprila 1944 odpeljanih iz Zadra. Šest zabojev, zakopanih pod kripto, je imelo priložen originalen seznam iz leta 1940, ostalih osem hranjenih pod stopniščem sv. Donata pa ne, vendar so naredili novega pri popisovanju v operaciji Zara (Mlikota 20I2, 


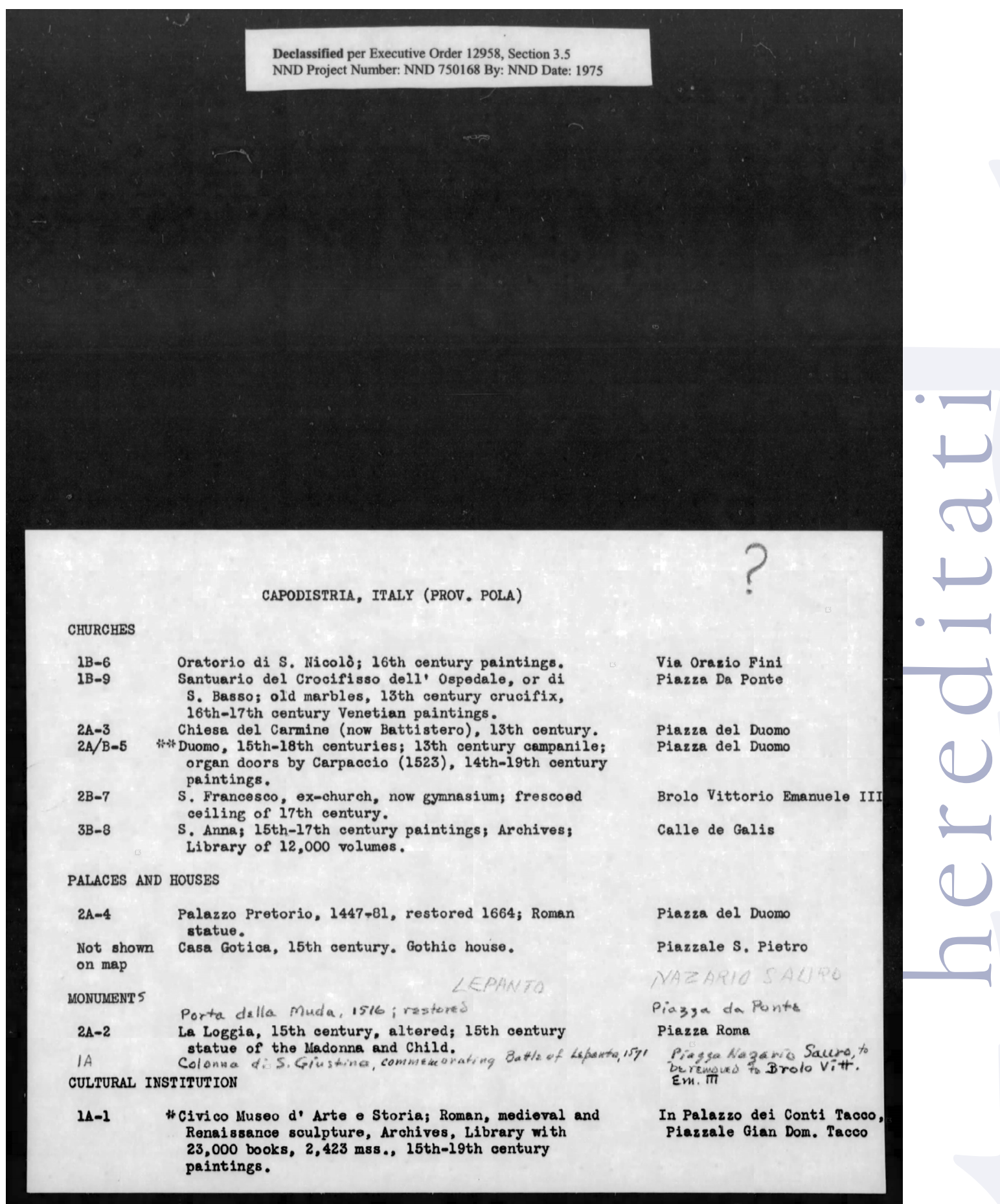

Priloga I: Seznam pomembnih umetnin in lokacij, ki jih je treba zaščititi v primeru spopada. MFAA, Roberts Commission, Maps Showing Areas to Be Spared Destruction During World War II, Europe: Hungary - Italy. Vir: https:// www.fold3.com/image/114/301220105 
275). Mnogo let so trdili, da je bil material iz Zadra odpeljan leta 1943, medtem ko dokumentacija MFAA dokazuje, da je bil odpeljan aprila 1944 po kapitulaciji Italije (Mlikota 20I2, 276).

\section{Vprašanje restitucije umetnin iz Istre v času socialisticne Jugoslavije}

Z Londonskim sporazumom leta 1954 je severni del Istre (brez Milj) postal del Jugoslavije. Zahteve po vrnitvi umetnin so se tokrat okrepile. Vlada FLRJ je takoj po Londonskem memorandumu že marca 1955 poslala italijanski vladi noto, v kateri je zahtevala vrnitev kulturne dediščine iz nekdanje cone B STO. Italijanska stran na noto ni odgovorila in je $\mathrm{v}$ nadaljnjih pogajanjih zavračala vse zahteve po vrnitvi, saj naj bi bilo po njihovem mnenju vprašanje razdelitve STO še vedno odprto (Žitko 2005, 31). Po podpisu Londonskega memoranduma 5. oktobra 1954 so $\mathrm{z}$ ureditvijo tržaškega vprašanja nastale nove razmere. Jugoslovanska stran je pričakovala, da se bo odprla možnost za vrnitev arhivov, umetnin in kulturnih predmetov, odnesenih iz cone B STO. Jugoslovanska ambasada v Rimu je leta I955 še pred koncem poganjanj v Gorici skušala doseči, da bi razširili delovno področje goriške komisije še na razdelitev arhivov v Trstu, italijanska stran pa se ni strinjala. Želeli so podrobne sezname jugoslovanskih zahtev, da bi jih preučili in v Trstu opravili priprave. V naslednjih letih je jugoslovanska stran poskušala doseči, da bi vprašanje kulturnih restitucij in delitev arhivov uredili v okviru Trsta med generalnim konzulatom FLRJ in generalnim komisariatom v Trstu (Oblak Čarni 2008, 288). Pristojne službe so seznam odnesenih umetnin skrbno pripravljale od leta I955 in ga vse do danes poglabljale in dopolnjevale (Hoyer 2005, 19).

Posebno vlogo je odigrala tudi Cerkev, katere vlogo pri vračanju je treba še raziskati. Takoj po prevzemu koprskega samostana sv. Ane so ljubljanski frančiškani sprožili postopek za vrnitev samostanskih liturgičnih predmetov, ki so jih leta 1947 italijanski redovniki odnesli iz Kopra. V zvezi s tem je bila ena glavnih dilem, ali se lahko predmeti vrnejo brez jugoslovanskih ca- rinskih postopkov in plačila carine. Izkazalo se je, da carine niso bili oproščeni. Ko naj bi slike iz Benetk, namenjene v samostan sv. Ane v Kopru, prispele na koprsko carino, niso smele preko meje, ker carina ni bila poravnana. $\mathrm{V}$ korespondenci med spomeniškim zavodom in jugoslovansko carino je spomeniški zavod pojasnjeval carini, da se za vrnitev odnesenih umetnin ne plačuje carina, a se zvezni jugoslovanski carinski urad za to ni zmenil. Posledično so se vsi predmeti vrnili v Benetke (Hoyer 2005, I8).

Po nenehnih intervencijah jugoslovanske vlade je italijansko zunanje ministrstvo konec leta 1959 privolilo na nadaljevanje pogajanj o restituciji umetniških in zgodovinskih dobrin. Delegaciji obeh strani sta se sestali I8. januarja 1960 v Milanu (Oblak Čarni 2008, 288). Jugoslovansko delegacijo je vodil svetnik Miloš Morača, italijansko pa pooblaščeni minister De Novalis. Na pogovorih so vsaj glede nekaterih vprašanj skoraj dosegli soglasje, vendar so bila pogajanja na željo italijanske strani prekinjena. Ko so se 27. aprila ponovno sestali v Rimu, je italijanska stran, ki jo je takrat vodil pooblaščeni minister Rodolfo Siviero, zastopala stališče, da italijanska delegacija, ki se je pogajala v Milanu, ni imela pooblastil za sklepanje sporazumov. Italijanska delegacija je predlagala odlog do junija. Ob snidenju meseca junija 1960 je vodja italijanske delegacije predlagal ponovno preložitev, dokler ne bi posamezna ministrstva predložila italijanski vladi poročila o predmetih, ki jih je zahtevala Jugoslavija (Oblak Čarni 2008, 288). Jugoslovanska delegacija je odlaganju nasprotovala, saj je menila, da so bile zahteve znane že dolgo in da so imeli italijanski organi dovolj časa, da bi jih preučili. Po ostrem protestu zunanjega ministrstva Jugoslavije so se pogajanja nadaljevala na politični ravni, brez sodelovanja izvedencev. V prostorih jugoslovanskega zunanjega ministrstva v Beogradu so med 6. in II. avgustom 1960 nadaljevali pogovore. Beograjski zapisnik so podpisali I. novembra, v njem so določili, da se morajo pogajanja čim prej končati. Predlagali so sporazum, s katerim bi dokončno uredili problematiko restitucije (Oblak Čarni 2008, 288). Popolnoma nereše- 
$467 / 55$.

BLENCO DEGLI ARREDI SACRI DA RITORNARE AL U.R.P. PROVINCIALE DI LUBIANA PBR LA CHIBSA DI S. AMNA IN CAPODISTRIA CUI APPARTENEVANO.

\section{1.- INo 3 (tre) calic1. Due in argento finemente lavorati. Uno con} la sola coppa d'argento.

2.- No 1 (una) pisside d'argento.

3.- No 1 (una) porta reliquie (piede di ottone dorato e porta reliquie d'argento).

Oltre alla biancheria già segnalata nel precedente elenco:

4.- $\mathbb{N}^{\circ} 22$ (ventidue) fra tovaglie e sopratovaglie.

5.- No 12 (dodici) camici. - sofice

6.- No 6 (sei) amiti.

7.- № 13 (tredici) corporali.

8.- $\mathbb{N}^{\circ} 15$ (quindici) pale.

9.- No 16 (sedici) purificatoi.

10.- No 16 (sedici) manutergii.
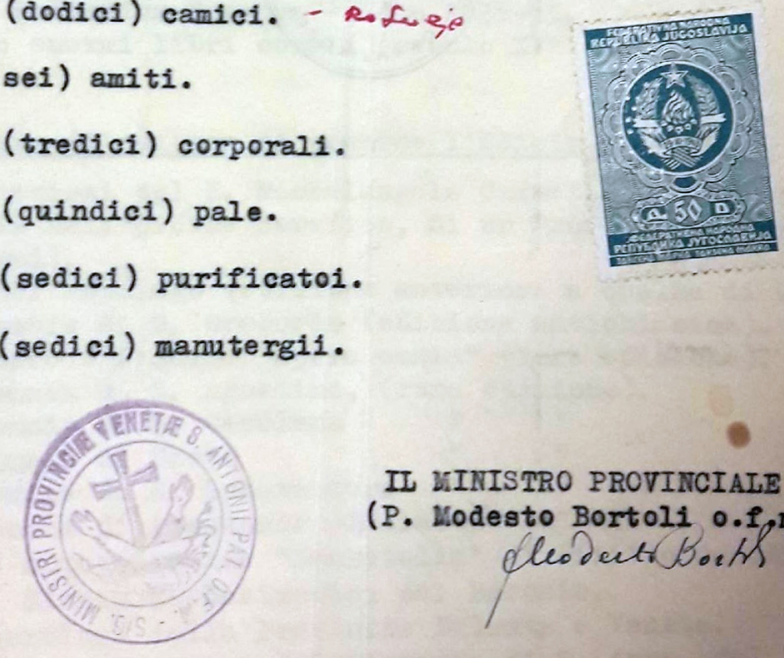

II UINISTRO PROVINCIALE

(P. Hodesto Bortoli 0.1,m.)

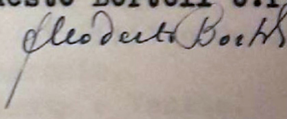

M.R.P. BENIANINO TOUSIC O.F.X.

Franciskanski samostan

Presernov trg 4

(Jugoslavia)

IJUBLJAITA

Priloga 2: Seznam odpeljanih liturgičnih predmetov. Vir: Arhiv Samostana sv. Ane v Kopru, foto: Janja Babelić 
no je ostalo vprašanje vračila arhivov in drugih kulturnih dobrin iz nekdanje cone B STO. V posebni prilogi beograjskemu zapisniku so zapisali, da je jugoslovanska stran med pogovori ponovila zahtevo po restituciji, saj so bili mnenja, da Londonski memorandum temelji na mirovni pogodbi in Italijo posledično obvezuje k vrnitvi umetnin, vendar naj italijanska delegacija ne bi imela navodil za razpravljanje o gradivu iz cone B STO (Oblak Čarni 2008, 289).

Vprašanje restitucije so ponovno odprli leta 196I v jugoslovansko-italijanskem Sporazumu o reguliranju restitucije kulturnih dobrin Jugoslaviji, ki je bil ratificiran 6. marca 1962 (Oblak Čarni 2008, 289, Žitko 2005, 3I). Pomembna je bila tudi Dunajska konvencija o pravu mednarodnih pogodb iz leta 1969, ki sta jo ratificirali obe državi. Pomembna je bila zaradi pisne korespondence med zunanjima ministroma SFRJ Milošem Minićem in Republike Italije Marianom Rumorjem o kulturni dediščini, s katero sta se jugoslovanski in italijanski minister dogovorila, da se bosta pol leta po uveljavitvi Osimskega sporazuma (1975) italijanska in jugoslovanska delegacija sestali in poskušali rešiti odprta vprašanja (Žitko 2005, 3I). Osimske sporazume, mednarodne pravne akte, sta Io. novembra 1975 podpisali Republika Italija in SFRJ, v mestu Osimo, z njimi pa so urejali vprašanje meja med državama. Na podlagi zgoraj omenjene korespondence med Minićem in Rumorjem, je bila ustanovljena jugoslovansko-italijanska komisija, ki je zasedala aprila 1978 v Rimu, decembra 1979 v Portorožu in 198I ponovno v Rimu. Jugoslovansko delegacijo je vodil Stjepan Gumel, direktor Zavoda za spomeniško varstvo SR Hrvaške, italijansko pa na prvem zasedanju veleposlanik Giovanni Falchi, na drugem in tretjem pa Mario Profili. Na prvem zasedanju je jugoslovanska delegacija predložila in obrazložila knjigo zahtev s 529 postavkami. Šlo je predvsem za gradivo nekdanje cone B STO. Leta 1979 je Mario Profili ostro napadel jugoslovansko delegacijo, saj je menil, da so zahteve pretirane in presegajo določila Osimskega sporazuma (Oblak Čarni 2008, 292). Italijanska stran je zavračala vsakršno raz- pravljanje o zahtevah po vrnitvi kulturnih dobrih $\mathrm{z}$ ozemlja, priključenega $\mathrm{z}$ mirovno pogodbo leta 1954. Pripravljeni so bili sprejeti le nekaj zahtev in še te izključno v svežnju, kar je pomenilo, da bi jugoslovanska stran morala sprejeti italijansko ponudbo v celoti ali od nje odstopiti. Italijanska delegacija je na tem srečanju uradno priznala, da korespondence Minić - Rumor ni ratificirala (Oblak Čarni 2008, 292). Jugoslovanska delegacija je imela pooblastila Cerkve oziroma verskih ustanov, da se dogovarja za restitucijo njihove kulturne dediščine (Žitko 2005, 32). Leta 198I je italijanska stran ponovila stara merila za dogovor, po katerih jugoslovanska stran ne bi imela pravice zahtevati materiala ne iz Istre ne iz Dalmacije. Italijanska komisija ravno tako ni želela razpravljati o gradivu, odnesenem pred letom 1940 in po letu 1945. Poleg tega bi jugoslovanska stran morala dokazati, kje točno v Italiji se posamezni predmeti nahajajo. Na tej točki so bila pogajanja blokirana. Sprejeli so skupni zapisnik, v katerem sta obe strani ugotovili razhajanja v razlagi korespondence Minić - Rumor in sporazuma iz leta 196I ter sklenili o tem obvestiti svoji vladi (Oblak Čarni 2008, 293). Leta 1987 je prišlo na Brionih do predsedniškega sestanka, na katerem so se dogovorili za nov datum sestanka komisij, do katerega pa ni prišlo (Oblak Čarni 2008, 293).

\section{Po osamosvojitvi Slovenije (I9gI)}

Slovenija je postala pravna naslednica Jugoslavije v Osimskih sporazumih z notifikacijo z dne 29. julija 1992 (Uradni list RS 1992). S tem je restitucijska komisija nadaljevala delo jugoslovanske delegacije, dodeljene za restitucijo umetnin. Še pred tem je jeseni I99I Slovenija pripravila revidiran seznam samo s slovenskimi terjatvami, ki je bil izročen italijanski strani (Oblak Čarni 2008, 293). Po osamosvojitvi Slovenije so se prizadevanja nadaljevala in Italija je $\mathrm{z}$ izmenjavo not potrdila pripravljenost za oblikovanje mešane slovensko-italijanske komisije, ki naj bi obravnavala nerešena vprašanja (Žitko 2005, 34). Kljub temu se $\mathrm{v}$ devetdesetih letih na področju odtujenih 
umetnin ni veliko dogajalo, najverjetneje zaradi vstopnih pogajanj Slovenije v Evropsko unijo.

Največji preboj se je zgodil, ko so italijanske oblasti is. maja 2002 sklicale tiskovno konferenco, na kateri je italijanski državni podsekretar na Ministrstvu za dediščino in kulturne dejavnosti Vittorio Sgarbi predstavil razloge, ki naj bi botrovali odprtju ir zabojev z umetninami iz obalnih mest, zaprtih od leta 1940. Uradni razlog naj bi bil nujnost restavriranja in konserviranja umetniških del. Glede na zgodovinske okoliščine pa lahko sklepamo, da so odprtje zabojev povzročili tudi drugi še neraziskani razlogi, ki so najbrž povezani s tem, da je Sgarbi mesec kasneje zaključil svoj mandat (podatki dostopni na spletni strani italijanske vlade - glej vire). Odprtje zabojev je odprlo pandorino skrinjico o restituciji umetniških del iz Kopra, Izole in Pirana (Hoyer 2005, I4). Posledično je prišlo tudi do restavriranja nekaterih umetnin in do njihove predstavitve na razstavi Histria: opere d'arte restaurate, ki je potekala v tržaškem muzeju Revoltella med 23. junijem 2005 in 6. januarjem 2006. Leta 2005 je izšel tudi obsežen katalog razstave, ki je vseboval številne strokovne prispevke, med drugim izpod peresa Vittoria Sgarbija, Francesce Castellani, Fabrizia Maganija, Stefanie Mason in drugih.

Omeniti je potrebno, da je junija 2004 potekal tridnevni mednarodni simpozij na Univerzi na Primorskem Istra in Jadran v zgodnjem nover veku: umetnostni dialog med obalo in celino, ki ga je vodil dr. Stanko Kokole. Kot je povedal dr. Kokole v intervjuju za Primorske novice, so na simpoziju predstavili za I5. in I6. stoletje najpomembnejša dela slovenske Istre, med katerimi so slike znanih mojstrov, kot so Vittore Carpaccio, Cima da Conegliano, Alvise Vivarini in Giovanni Bellini. Tuji poznavalci so bili slabo seznanjeni s problematiko odtujenih umetnin (Figelj 2004, 16). Kot navaja novinarka Klavdija Figelj, je italijanska stran zavrnila predlog Slovenije za zasnovo skupne komisije, ki naj bi poskrbela, da se dela vrnejo na stara mesta (Figelj 2004, 16).
$\mathrm{V}$ tem času je prišlo tudi do pomembnega premika: izr. prof. dr. Sonja Ana Hoyer je odkrila nahajališča večine še pogrešanih umetnin iz samostana sv. Ane. Rezultat odkritja je bil izid temeljne monografije, ki obravnava problematiko odtujevanja umetnin s področja današnje Slovenije, V Italiji zadržane umetnine iz Kopra, Izole, Pirana. Pomen monografije je predvsem v tem, da je prva publikacija, ki se dotika omenjene problematike in omenja nekatera nahajališča odtujenih artefaktov. Slednji so bili tako prvič predstavljeni slovenski javnosti, s čimer je monografija tudi oživila javno razpravo o tej tematiki. Od leta 2005 dalje ni bilo konkretnejših premikov pri vračanju umetnin. De iure slovensko-italijanska restitucijska komisija še vedno obstaja, de facto pa je precej mirujoča.

Uradno stališče italijanske strani je kompleksno, vendar lahko povemo, da italijanska stran ni naklonjena vračanju iz istrskih obalnih mest odtujenih umetnin. Kot piše Vittorio Sgarbi v katalogu Histria: opere d'arte restaurate: da Paolo Veneziano a Tiepolo: [Trieste, Civico Museo Revoltella 23 giugno 2005 - 6 gennaio 2006], ki je nastal ob razstavi z umetninami iz omenjenih zabojev, si nihče ni upal dotakniti teh umetnin, saj so se bali diplomatskega in političnega vprašanja, ki bi ga odprle (Sgarbi 2005, 40). Vittorio Sgarbi trdi, da obstajata dva možna pogleda na situacijo odtujenih umetnin: na eni strani princip, po katerem naj bi umetnine pripadale fizičnemu in geografskemu kontekstu, iz katerega izhajajo, druga možnost pa je princip, po katerem naj bi umetnine pripadale zgodovinskemu in kulturnemu kontekstu, ki jih je ustvarila, pri katerem teritorij predstavlja samo geografsko in fizično dimenzijo. $V$ večini primerov se ti dve možnosti prekrivata, kar pa po Sgarbijevem mnenju ne velja za Istro (Sgarbi 2005, 40). Sgarbi namreč trdi, da je historični ambient, v katerem so umetnine nastale, kulturno pripada italijanskemu kontekstu, in da umetnine posledično ne sodijo več na teritorij, od koder so izhajale, saj je le-ta povsem spremenjen, slovaniziran in politično razdeljen med Slovenijo in Hrvaško (Sgarbi $2005,4 \mathrm{I}$ ). 


\section{Zaključek}

Historiat vprašanja restitucije istrskih umetnine dokazuje izrazito kompleksnost problema. Dogodki iz prve in druge svetovne vojne so pripeljali do današnjega statusa quo glede vračila umetnin. Predmeti so bili po drugi svetovni vojni odpeljani na varno, vendar se zaradi sprememb meja v teh okrajih niso nikdar vrnili na svojo izvorno lokacijo. Kljub ustanovitvi komisije za restitucijo po vojni in poskusov dogovarjanja z Italijo se do konca devetdesetih letih na področju odtujenih umetnin ni veliko dogajalo. Kljub številnim naporom slovenske politike in stroke, se je največji premik zgodil, ko so italijanske oblasti leta 2002 sklicale tiskovno konferenco na to temo, kar je oživilo problem restitucije umetniških del iz Kopra, Izole in Pirana. Kulturna dediščina se je izkazala kot politični resurs, s katerim se zelo enostavno manipulira. Zaradi tega, mora biti poudarek na procesu vedno novega ustvarjanja kultur $\mathrm{v}$ sedanjosti in ne na preprostem obračanju k tradiciji kot izgovoru za ohranjanje družbenih, ekonomskih in političnih neenakosti (Harrison 2013, 230). Po Harrisonu bi morali dojemati ohranjanje različnosti, ne kot proces reševanja ali ohranjanja ogroženih relikvij iz preteklosti, ampak kot aktiven in kreativen proces iskanja temeljev za skupno človečnost $\mathrm{v}$ vseh oblikah, ki so nam dostopne v sedanjosti (Harrison 20I3, 164), s čimer se potrjuje sodobna teorija o prepoznavanju novih, celostnih diskurzov dediščine (inclusive heritage discourse; Kisić 2016).

Dediščina je več kot samo zapuščina, je proizvod sedanjosti, ki si ga lastijo različne družbene skupine kot instrument za ustvarjanje novih identitet in njenih referentov. Dediščina je ideološki konstrukt, ki izhaja iz kompleksnih političnih, zgodovinskih in družbenih dinamik, $s$ katerimi se določene strukture in reference izbirajo, kombinirajo in interpretirajo, da bi pridobili nove pomene in identitetne simbole (Anico 2009, 67). Dediščina je torej politični proces in kot taka a priori vsebuje moč politične izbire idej, vrednotenja in znanja, ki jih razstavi javnosti preko dediščinskih diskurzov in naracij (Ani- co 2009, 67). Ravno zaradi tega so dediščina in muzeji močna sredstva za posredovanje idej in vrednot v procesih ustvarjanja pomena. Predstavljajo kulturno ideologijo in so v vseh pogledih (zavedno ali nezavedno) politični. Muzeji in dediščina imajo ta dar, da lahko ustvarjajo nove identitete, vrednote in razumevanja ter promovirajo kulturna doživetja, ki omogočajo gledalcem, da gradijo lastne pomene in interpretacije. To pa ni preprosta naloga, saj so muzeji mnogokrat del širše politične debate in igrajo pomembno družbeno vlogo $\mathrm{v}$ naštetih procesih (Anico 2009, 68). Pomembno je vedeti, da premikanje ostalin in pomnikov lahko življenjsko vpliva na nacionalno in kulturno identiteto (Lowenthal 2015, 447). Prav to težo in kompleksnost pa nosi vprašanje odtujenih umetnin iz obalnih mest.

\section{Povzetek}

Problematika restitucije umetnin je izredno kompleksen problem, saj je kulturna dediščina del preteklosti s katero se lahko zelo enostavno manipulira. Vsak primer odtujevanja si je med seboj različen. Nekaj primerov premeščanja artefaktov je odmevnejših, usoda večine odtujenih umetnin pa je javnosti nepoznana. Med manj poznanimi je tudi prmer Zadarskega zaklada, ki je bil med drugo svetovno vojno, podobno kot umetnine iz Kopra, Izole in Pirana, premeščen na ozemlje današnje Italije. Zaradi dogodkov iz prve svetovne vojne so te kraje dojemali kot potencialno nevarne za hranjenje artefaktov. Med odpeljanimi umetninami iz Istre, je posebno zanimiv primer frančiškanskega samostana sv. Ane, saj je bil lastnik umetnin frančiškanski red in ne država, kot npr. pri artefaktih, odpeljanih iz koprskega muzeja. Zaradi tega so se umetnine tudi po kapitulaciji Italije še vedno premikale iz države v državo, saj je bil frančiškanski red prisoten tako na področju Jugoslavije kot $\mathrm{v}$ Italiji. V Mirovni pogodbi sklenjeni z Italijo (1947) je pisalo, da mora Italija vrniti Jugoslaviji premoženje in arhivsko gradivo, ki je bilo odneseno z območja, okupiranega leta 1941. Z Londonskim memorandumom (1954) je slovenska Istra pripadla Jugoslaviji in zahteve po vrnitvi umetnin so se tokrat okrepile. Vlada FLRJ je takoj po Londonskem memorandumu že marca 1955 poslala italijanski vladi noto, $v$ kateri je zahtevala vrnitev kulturne dediščine iz nekdanje cone B STO. Kljub ustanovitvi 
komisije za restitucijo in poskusov dogovarjanja z Italijo se do konca devetdesetih letih na področju odtujenih umetnin ni veliko dogajalo. Največji premik se je zgodil, ko so italijanske oblasti I5. maja 2002 sklicale tiskovno konferenco, na kateri se je italijanski državni podsekretar na Ministrstvu za dediščino in kulturne dejavnosti Vittorio Sgarbi predstavil vsebino I zabojev odpeljanih iz Istre leta 1940. To je oživilo problem restitucije umetniških del iz mest Slovenske Istre, ki še danes ostaja odprt.

\section{Summary}

The issue of restitution of artworks is an extremely complex problem, since cultural heritage is part of the past that can be easily manipulated. Case of alienation differ strongly among each other. Some examples of relocated artefacts are prominent, while the fate of most relocated artworks remains unknown to the public. Such is the case of the relocated artefacts from the northern Istrian town during WWII and the consequent dispute over their appurtenance. Due to the historic events of World War I, the Slovenian territories that today border with Italy, were perceived during World War II by the then Italian authorities as potentially dangerous for storing artistic artefacts. Among the items taken from Istria, the most interesting is the Franciscan monastery of St. Anna / Sv. Ana in Koper/Capodistria since the owner of the artworks was the order itself and not the State as was the case for the Municipality museum in the town. As a result, the artworks from one country to the other even after the end of WWII, since the order was present both in Italy and Yugoslavia. The Peace treaty of Paris (1947) stated that Italy should return to Yugoslavia all the artefacts and archival material that has been relocated from the occupied areas by 194I. With the London Memorandum (1954), the contested area of Northern Istria became part of Yugoslavia, so the claims of restitution were revived. A first note with the claim of restitution was sent by the Yugoslav government to the Italian one already in 1955. Despite the establishing of a Restitution Commission and various attempts to negotiate with Italy, no further developments occurred until late 1990s. A main shift took place when the Italian authorities convened a press conference on May 15, 2002 at which the deputy minister for Culture, Vittorio Sgarbi, presented the content of II boxed that were relocated from Istria in 1940. The issue remains open until present, while it raises a fundamental theoretical question regarding the conservation of artefacts on their original locations in contested areas that underwent a major change in population.

\section{Viri in literatura}

Anico, M. 2009. "Representing identities at local municipal museums: Cultural forums or identitiy bunkers?" V: Heritage and Identity, Engagement and Demission in the contemporary World, urednici: Marta Anico in Elsa Peralta, 63-75. New York. Ashworth, G. J., Graham B., Tunbridge J. E. • 2007. Pluralising pasts: Heritage, Identity and Place in Multicultural Societies, London.

Algeri G. in L'Occaso S. 2005. "Le opere d'arte della chiesa di San't Anna di Capodistria." $\mathrm{V}$ : Histria: opere d'arte restaurate: da Paolo Veneziano a Tiepolo: [Trieste, Civico Museo Revoltella 23 giugno 2005 - 6 gennaio 2006], 87-96. Milano: Electa.

Benjamin, W. 2003. Umetnina v času, ko jo je mogoče tehnično reproducirati. Izbrani spisi. Ljubljana: Studia humanitatis.

Casadio, P., in Castellani F. 2005. "Per introdurre." V: Histria: opere d'arte restaurate: da Paolo Veneziano a Tiepolo: [Trieste, Civico Museo Revoltella 23 giugno 2005 - 6 gennaio 2006], 29-30. Milano: Electa.

Čebron Lipovec, N. 2015. "'I'm Telling the Story of the Town": Places in a Contested Space." V: At Home but Foreigners. Population transfers in 2oth Century Istria. Uredniki: Katja Hrobat Virloget, Catherine Gousseff, Gustavo Corni, I89207. Koper: University of Primorska, Science and Research Centre, Annales University Press.

Figelj, K. 2004. "O renesansi v Istri lahko govorimo”: dr. Stanko Kokole o I5. in 16. stoletju. Primorske novice, 58, št. 5I (24. jun. 2004), 16. 
Gombač, B. 1996. Slovenija, Italija; od preziranja do priznanja. Ljubljana, Debora.

Harrison, R. 2013. Heritage: Critical approaches. Oxford: Routledge.

Harvey, D. C. 200I. "Heritage pasts and heritage presents: Temporality, meaning and the scope of heritage studies." International Journal of Heritage Studies, Vol. 7 , No. 4.

Hoyer, S. A. 2005. "V Italiji ostale umetnine iz Kopra, Izole in Pirana.” V: V Italiji zadržane umetnine iz Kopra, Izole, Pirana, I4-2I, 36-43, 58-66. Piran/Pirano: Zavod za varstvo kulturne dediščine Slovenije, Območna enota/ Instituto per la tutela dei beni culturali della Slovenia, Unità territoriale/ Institute for the Protection of Cultural Heritage of Slovenia, Regional Office; Ljubljana: Ministrstvo za kulturo Republike Slovenije/ Ministero per la cultura della Repubblica di Slovenia/ Ministry of Culture of the Republic of Slovenia.

Ikram, S. 20I I. "Collecting and Repatriating Egypt's Past: Towards a New Nationalism." V: Contested Cultural Heritage, Religion, Nationalism, Erasure, and Exlusion in a Global World, urednica: Helaine Silverman, I4I-I54. New York: Springer.

International Council of Monuments and Sites. 2003. Doktrina / Doctrine, Mednarodne listine ICOMOS / ICOMOS International Charters I. Uredil Jovo Grobošek. Ljubljana: Združenje za ohranjanje spomenikov in spomeniških območij ICOMOS.

Kisić, V. 20I6. Governing heritage dissonance. Amsterdam, European Cultural Foundation.

Knapp, A. B., in Antoniadou, S. 1998. "The cultural heritage of Cyprus." V: Archaeology Under Fire: Nationalism, politics and heritage in the Eastern Mediterranean and Middle East, urednica: Lynn Meskell, 13-43. London.
Lowenthal, D. 2015. The past is a foreign country: revisited. Cambridge: Cambridge University Press.

Magani, F. 2005. 1940-1946. "La

Soprintendenza ai Monumenti e alle

Gallerie della Venezia Giulia e del Friuli e la protezione delle opere d'arte in Istria."

V: Histria: opere d'arte restaurate: da Paolo Veneziano a Tiepolo: [Trieste, Civico Museo Revoltella 23 giugno 2005 - 6 gennaio 2006], 3I-39. Milano: Electa.

Mason, R., in Baveystock, Z. 2009. "What role can digital heritage play in the reimagining of national identities? England and its icons." V: Heritage and Identity, Engagement and Demission in the contemporary World, urednici: Marta Anico in Elsa Peralta, 15-29. New York.

Mlikota, A. 2012. "MFAA - Dosje Zadar, nove spoznaje o umjetninama odnesenima iz zadra u italiju za vrijeme drugog svjetskog rata." Asseria, vol. 10, 2012: 239-210.

Oblak Čarni, M. 2008. "Restitucije arhivov, kulturno umetniških predmetov in bibliotek ter delitev arhivov med Jugoslavijo in Italijo po drugi svetovni vojni." Arhivi 3I, 2008, št. 2.: 279-294.

Pirjevec, J. 2007. "Trst je naš!” - Boj Slovencev za morje (I848-I954). Ljubljana: Nova revija.

Poročilo slovensko-italijanske zgodovinskokulturne komisije (Koper, 25. julij 2000). Zadnji dostop 22. I. 2019. http://www. mzz.gov.si/fileadmin/pageuploads/ Zakonodaja_in_dokumenti/dokumenti/ Porocilo_SIZKK.pdf

Renfrew, C. 2000. Loot, Legitimacy and Ownership. London: Bristol Classical Press.

Rogoznica, D. 2015. “Organizacijske posebnosti in problemi spomeniškega varstva $\mathrm{V}$ koprskem okraju (1945-1962).” V: Začetki spomeniške službe v Istri, urednica: Deborah Rogoznica, 243-280. Koper: Histria editiones.

Silverman, H. 20ir. "Contested Cultural Heritage: A Selective Historiography.” 
V: Contested Cultural Heritage, Religion, Nationalism, Erasure, and Exlusion in a Global World, urednica: Helaine Silverman, I-50. New York.

Sgarbi, V. 2005. "Arte d'Istria, arte degli Istriani." V: Histria: opere d'arte restaurate: da Paolo Veneziano a Tiepolo: [Trieste, Civico Museo Revoltella 23 giugno 2005 - 6 gennaio 2006], 40-46. Milano: Electa.

Smith, L. 2006. Uses of heritage. Routledge. Spada, I. 2017. L'Italia in Istria, Tutela, conservazione e restauro dei beni culturali tra le due guerre mondiali. Venezia: Marsilio.

Uradni list. 1992. Akt o notifikaciji nasledstva sporazumov nekdanje Jugoslavije z Republiko Italijo. Uradni list RS, št. 40/1992, z dne I4. 8. 1992. Zadnji dostop 22. I. 2019. https://www.uradni-list.si/ glasilo-uradni-list-rs/vsebina/1992-020060 ?sop $=1992-02-0060$

Žitko, S. 2005. "Prizadevanja oblasti za vrnitev v Italiji ostale kulturne dediščine.” V: $V$ Italiji zadržane umetnine iz Kopra, Izole, Pirana, 30-35. Piran/Pirano: Zavod za varstvo kulturne dediščine Slovenije, Območna enota/ Instituto per la tutela dei beni culturali della Slovenia, Unità territoriale/ Institute for the Protection of Cultural Heritage of Slovenia, Regional Office; Ljubljana: Ministrstvo za kulturo Republike Slovenije/ Ministero per la cultura della Repubblica di Slovenia/ Ministry of Culture of the Republic of Slovenia.

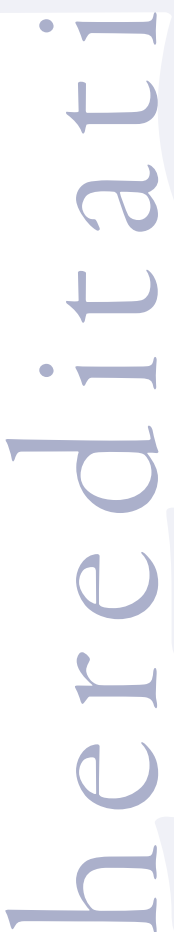




\title{
Kulturna baština Prijestonice Cetinja
} Simboli kolektivnog sjećanja na Drugi svjetski rat (Bunkeri iz doba okupacije u Drugom svjetskom ratu)

\author{
Dobrila Vlahović \\ Ministarstvo kulture Crne Gore
}

Period Drugog svjetskog rata ima posebo značenje u istoriji Prijestonice Cetinje, prema kojem gradani Cetinja baštine kult kolektivnog sjećanja. To pokazuju pokazuju i brojna spomen obilježja, koja se nalaze u ovom gradu i koja su zbog istorijskog značaja, zakonom zaštićena.

Kako je ovaj segment crnogorske kulturne baštine nedovoljno istražen, u radu je sa više aspekata ukazano na njihov značaj i ulogu. Takođe, kroz studiju slučaja, skrenuta je pažnja na specifičnu vrstu spomen obilježja, koju kada govorimo o Crnoj Gori, nalazimo samo na Cetinju, Bunkeri iz doba okupacije u Drugom svjetskom ratu. Kako se štite i u kakvom su stanju, pokazuju rezultati istraživanja na koje se osvrćemo u ovom radu.

Ključne riječi: Cetinje, Drugi svjetski rat, kulturne dobro, spomen obilježja, NOB-a, Bunkeri iz doba okupacije

The period of the Second World War has a special meaning in the history of the Capital of Cetinje. According to this period, the citizens of Cetinje respect the cult of collective memory. This is confirmed by the numerous memorials found in this city. because of their historical significance, they are protected by law. As this segment of Montenegrin cultural heritage is under-researched, the article presents in several aspects their importance and role. Also, through a case study, attention to a specific kind of memorial, which when we talk about Montenegro, we find only in Cetinje, Bunkers from the time of occupation in World War II. How they protect themselves, and their condition is demonstrated by the results of the research, we look at in this article.

Keywords: Cetinje, World War II, cultural property, memorials, NOB, Bunkers from the occupation.

etinje je manji grad, koji pripada Južnoj regiji Crne Gore. ${ }^{1}$ Nekadašnji centar crnogorske države, danas je kulturno-istorijska i duhovna Prijestonice Crne Gore, ${ }^{2}$ o čemu

I Teritorija Prijestonice Cetinje obuhvata površinu od $910 \mathrm{~km} 2$, od čega gradska zona $6 \mathrm{~km} 2$. Prema rezultatima popisa stanovništva iz 2011. na teritoriji Prijestonice živi 16.757 stanovnika, odnosno 2,7\% ukupne populacije Crne Gore, od čega na gradskom području 13.991 stanovnika. Izvor:http://www.cetinje.me/

2 Cetinje je na osnovu zakonodavnog akta donijetog 29. decembra 1993. godine, proglašeno Prijestonicom Crne Gore. A, Glavni grad je Podgorica. svjedoči bogata kulturna baština iz različitih epoha (Dragićević 1956, 372-373).

U ovom radu, dat je istraživački osvrt na poseban segment kulturne baštine Prijestonice Cetinje, spomen obilježja, koja podsjećaju na događaje i žrtve Drugog svjetskog rata, zbog čega su zakonom zaštićena i imaju status kulturnog dobra. Kroz istorijski kontekst i ulogu Cetinja u Drugom svjetskom ratu, ukazano je i na poslijeratni period i društvene okolnosti, koje su afirmisale tekovine Narodnooslobodilačke borbe, kroz podizanje spomen obilježja, sa glavnim ci- 
ljem, da se osnaži kolektivno sjećanje na taj period i da se ne zaboravi.

Kako u proteklom periodu u Crnoj Gori nijesu vršene temeljne analize i istraživanja, ove vrste kulturnih dobara, u ovom radu je kroz studiju slučaja, kulturno dobro, Bunkeri iz doba okupacije u Drugom svjetskom ratu, dat opšti osvrt na istraživanja, koja su sadržajno povezana sa rezultatima istraživanja, za potrebe doktorske disertacije.

\section{Prijestonica Cetinje i kolektivna} memorija na Drugi svjetski rat

Kaja Širok je pisala o javnim spomenicima, ukazujući da su oni

\section{proizvod posredovanja izmedu zajednica i njeno kolektivno pamćenje, podsjećajući da, potisnute slike prošlosti, događaji koje je zajednica odbacila, ukazuju na anomalije u društvu i da se samo potvrdivanjem tih pozi- tivnih slika prošlosti jača kolektivni identitet društvene zajednice (Širok 20I2, 63I-646).}

Neposredno nakon Drugog svjetskog rata, podizanje spomen-obilježja bilo je dio šireg narodnog pokreta i važan dio svakodnevnih praksi ljudi. Oko $80 \%$ svih jugoslovenskih spomenika podignutih u prvih ro godina izgrađeno je na spontan i nekontrolisan način. Tek od polovine I950-ih politika sjećanja postaje predmet interesovanja etabliranih političkih organizacija i zvaničnih komisija zaduženih da obilježe taj period (Kirn, Burghardt 2012, 9-19). Takođe, i u crnogorskom poslijeratnom društvu, spomenici stradalim borcima Narodnooslobodilačkog rata bili su prvi simboli kulta revolucije i tradicije NOB-a (Prekić 2015, 279-312). Kada govorimo o Cetinju, veliki broj Cetinjana zadržao je memoriju na taj period i sve glasnije isticao zahtjev za njegovanje kulturno - istorijske tradicije svoga naroda (Martinović, Marković 1992, 36-50).

Cetinje je u dugotrajnoj oslobodilačkoj borbi izgradio poseban mentalitet crnogoraca, kod kojih su junaštvo, pregalaštvo, visoki ratnički moral i čojstvo predstavljali najveće ljudske vrline (Ičević 2015, 60-IO0). U tom patrijarhalnom društvu, razvijao se ideal čovjeka-pregaoca, sposobnog za najveće žrtve, riješenog da ide do nemogućeg, "neka bude što biti ne može"(Njegoš). Zbog zasluga u Drugom svjetskom ratu, Cetinje je odlikovano ordenom Narodnog heroja i postalo pedeseti heroj ${ }^{3}$ (MP Istorijskog jezgra Cetinja 2009/2014).

Danas Cetinje, svojim istorijskim kontekstom pedstavlja grad kulture i Prijestonicu Crne Gore (Vlahović 2012, 52), u kojoj se nalazi 120 nepokretnih kulturnih dobara, ${ }^{4}$ od nacionalnog značaja, od čega je više od $40 \%$ posvećeno periodu Drugog svjetskog rata, što ukazuje na njegovu kolektivnu memoriju prema tom periodu (Martinović, Marković 1992, 40-55).

\section{Kulturna dobra Cetinja - simboli kolektivnog sjećanja na perod NOR-a}

Spomen obilježja sa statusom kulturnog dobra, predstavljaju valorizovani segment crnogorske kulturne baštine od opšteg interesa, koji se štiti i čuva. ${ }^{5}$ Pored istorijskog i memorijalnog značaja, mogu imati i druge kulturne vrijednosti, koje ukazuju na njihov značaj, svojstva i osobenosti (autentičnost i integritet, jedinstvenost i rijetkost, stepen očuvanosti, arhitektonski, umjetnički, naučni, ambijentalni, pejzažni, socio-ekonomski ili drugi društveni znašaj).

$\mathrm{Na}$ teritoriji Crne Gore, status kulturnog dobra ima 582, spomen obilježja. Od toga, na teritoriji Prijestonice 55, a 50 je posvećeno događajima, žrtvama i borcima iz perioda Drugog svjet-

Cetinjani su u oslobodilačkom ratu 194I-1945. nastavili da ispisuju slavnu istoriju svog grada. U partizanskim jedinicama sa cetinjske teritorije borilo se 4.965 boraca. Cetinjska opština dala je 49 narodnih heroja. Zbog ovakvog patriotizma, Josip Broz Tito, predsjednik Jugoslavije, je 7. maja 1975. dodijelio gradu Cetinju, Orden narodnog heroja, povodom tridesetogodišnjice oslobođenja zemlje. Orden je svečano uručio i3. jula 1975. godine, na Ljetnoj pozornici u Cetinju, predsjednik Republike Crne Gore, Veljko Milatović).

4 Izvor: Uprava za zaštitu kulturnih dobara Crne Gore (UZKD CG).

Zakon o zaštiti kulturnih dobara ("Sl. list CG", br. 49/ı).

6 Kriterijumi za utvrdivanje kulturne vrijednosti dobra su propisani, Zakonom o zaštiti kulturnih dobara, ("Službeni list CG", br. 049/ı od I3.08.2010), a bliže definisani Pravilnikom o bližim kriterijumima I postupku utvrdivanja kulturne vrijednosti dobra ("Sl. list CG", br. 4I/11, 2011.godina). 
ЗАВОД ЗА ЗАШТИТУ СПОМЕНИКА

КУЛTY.PE HP ЦРНЕ ГОРЕ - ЦЕТКњE

$$
\begin{gathered}
\text { Број } 08-7.0 / 1 \text {. } \\
4-V I \ldots \text { 196.2. године }
\end{gathered}
$$

На основу члана 32 Закона о заштити споменика културе (Службени лист НРЦГ број 36/60) и члана 1 и 2 Правилника о регистровању споменика културе у НР Црној Гори, (Службени лист НРЦГ број 9/6i) Завод за заштиту споменика културе Народне Републике Црне Горе повео је пос-

\begin{tabular}{|c|c|c|}
\hline Aутор: & & Година настанка: \\
\hline Bpcra: spomenici' 1 OB-a & & Величина: \\
\hline Mjecro: ${ }_{\text {OKolina Cetinja }}$ & Aapeca: & \\
\hline Имао: Opštinski odbor Saveza borace & Адреса: & \\
\hline
\end{tabular}
тупак за утврђивање споменичних својстава на следећем споменику:

- Поступак је поведен на основу пријаве коју је поднио овом Заводу

\begin{tabular}{|l|l|l|}
\hline Назив, име: & Број пријаве: \\
\hline Мјесто, датум: & Aдреса: & \\
\hline
\end{tabular}

На основу извјештаја којега је поднијела Комисија формирана рјешењем Завода за заштиту споменика културе Народне Републике Црне Горе број .............. у циљу констатовања споменичних вредности пријављеног споменика, а која је била састављена од следећих стручних лица:

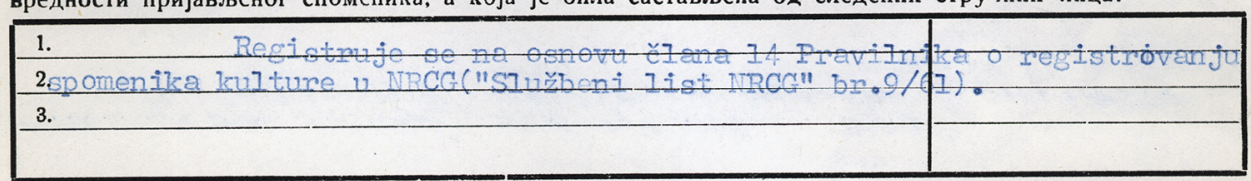

Завода за заштиту споменика културе Народне Републике Црне Горе, послије увида у комисијски извјештај, гдје су констатована споменична својства пријављеног споменика и предлог Комисије за увођење пријављеног споменика у Регистар споменика културе Народне Републике Црне Горе, доноси

\section{$P$ J U $E$ Њ $E$}

○ увођењу горенаведеног споменика културе у Регистар споменика културе Народне Републике Црне Горе ОБРАЗЛОЖЕІЬЕ:

$$
\text { Rješenjem br.276-60, a shodno Zakonu o żastiti spomeniłxa }
$$
lkulturewx u NRCG, Bunkeri iz doba oluupacijezx u olzolini Cetinja, uvode st u Registar nepokretnih spomenika kulture NRCG i time stavljaju pod zaštitu Zak:ona.

Против овог рјешења имаоц може уложити жалбу Савјету за културу Извршног вијећа НС HP Црне Горе у року од 15 дана од примитка овог рјешења. Жалба се доставља преко овог Завода. Рјешење доставити имацу споменика културе, Савезном Институту за заштиту споменика културе, надлежном народном одбору општине, надлежном среском суду (уколико се ради о непокрет ном спомеиику културе) и реферату за документацију овог Завода.

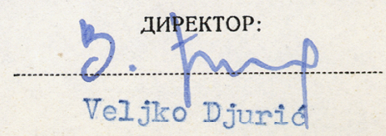


ЗАВОД ЗА ЗАШТИТУ СПОМЕНИКА

НУЛТУРЕ НР ЦРНЕ ГОРЕ - ЦАЕТИњЕ
БРОЈ ФОТОТЕКЕ:

СНИМиО:

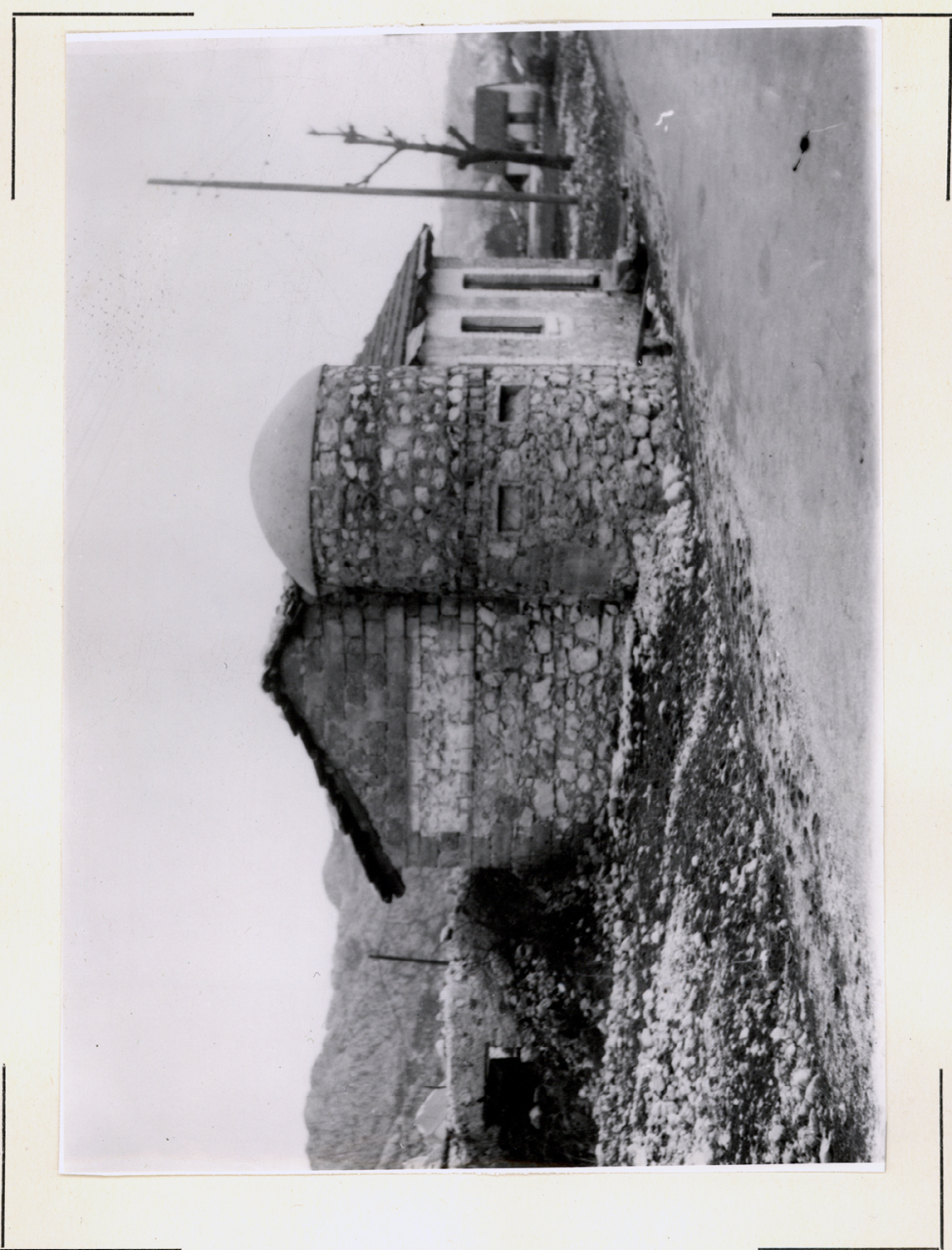

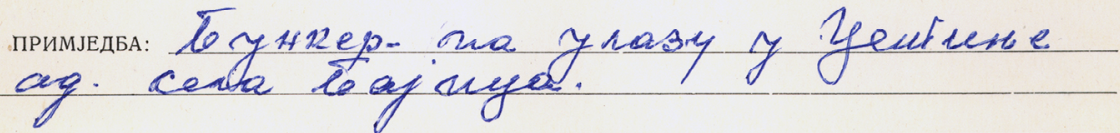


ku, napadačku i odbrambenu funkciju” (Martinović 1983,232 ).

\section{Bunkeri iz doba okupacije u Drugom svjetskom ratu - (Nepokretni spomenici kulture, spomenici NOB-a)}

Shodno ranijim propisima iz oblasti kulturne baštine, zakonsku zaštitu spomenika Narodne revolucije, koji su podizani u poslijeratnom periodu, sprovodio je tadašnji Zavod za zaštitu spomenika kulture NR Crne Gore, ${ }^{1 \circ}$ a na osnovu

\section{Komisije za pregled spomenika narodne revolucije”, nakon čega je Komisija Zavodaı proglašavala," da spomenik ima istorijski značaj i da predstavlja spomenik Narodne revolucije, te se uvodi u Registar nepokret- nih spomenika kulture i time stavlja pod zaštitu zakona.}

Tako su spomenici NOB-a, po tadašnjim propisima dobijali status nepokretnog spomenika kulture.

Kada su u pitanju, Bunkeri iz doba okupacije u Drugom svjetskom ratu, koje je izgradila okupatorska vojska, takođe su dobili taj status, rješenjem u kojem se navodi,

\section{da se Bunkeri iz doba okupacije u Drugom svjetskom ratu stave pod zaštitu države, te da se stavlja do znanja da se shodno zakonu," ne smiju vršiti nikakve opravke, dozidivanja, restauriranja,ili pomjeranja zaštićenog ob- jekta, bez znanja i odobrenja,od strane ovog Zavoda $^{14}($ sl. I $)$}

Zaštita (postupak utvrdivanja spomeničkih svojstava) sprovodio se u skladu sa Zakonom o zaštiti spomenika kulture (Službeni list NRCG br.36/60) i Pravilnikom o registrovanju spomenika kulture u NRCG čl.I4. (Službeni list NRCG br.9/6I);

II Komisija Zavoda je brojila tri člana (po jedan iz Zavoda, opštinskog odbora za kulturu i opštinskog odbora saveza boraca NOR-a),

I2 Uprava za zaštitu kulturnih dobara. Broj Dosijea: 386/D-NR.

I3 Zakon o zaštiti spomenika kulture i prirodnih rijetkosti NRCG, članak 2.

I4 Rješenje o stavljanju pod zaštitu br. 276/60 od 22.04.1960. godine. (Izvor: Uprava za zaštitu kulturnih dobara CG).
To je bio i osnov, da se 1962. godine, uvedu u Registar nepokretnih spomenika kulture NRCG $i$ time stave pod zaštitu Zakona (sl. 2). ${ }^{\text {Is }}$

\section{Istraživanja}

Imajući u vidu nedovoljnu istraženost ovog segmenta crnogorske kulturne baštine, fokus interesovanaja usmjeren je na spomen obilježja, vezana za NOB-u, sa statusom kulturnog dobra. U okviru Projekta revalorizacija ${ }^{16}$ kulturnih dobara, koji je započet krajem 2013. godine, ${ }^{17}$ po prvi put od uspostavljanja sistema zaštite u Crnoj Gori (institucionalnog i zakonodavnog 1948/9), u razmatranje su uzeta i spomen obilježja, kao segment nepokretne kulturne baštine. Glavni cilj bio je provjera kulturnih vrijednosti, što podrazumijeva kontinuiran postupak. Međutim, kada su u pitanju spomen obilježja, istraživanja započeta 2013/14 nijesu bila naučnog karaktera, te rezultati nijesu naučno obrađeni i publikovani. Dalja istraživanja bazirana su na naučno istraživačkom pristupu. ${ }^{18}$

U tom kontekstu, kada je u pitanju Prijestonica Cetinje, posebnu pažnju izazvali su, Bunkeri iz doba okupacije u Drugom svjetskom ratu. Istraživanjem dokumentacije ${ }^{\mathrm{I} 9}$ ustanovljeno je

I5 Rješenje o uvodenju u Registar spomenika kulture NRCG br. o8709/1 od 4.06.1962. godine. Broj registra: 386; Knjiga II (druga); Strana 369-370; Broj Dosijea: 386/D-NR; (Izvor Uprava za zaštitu kulturnih dobara $\mathrm{CG}$ ).

I6 Revalorizacija je stručna ili naučna ocjena svojstava, osobenosti i značaja kulturnog dobra, radi provjere njegove kulturne vrijednosti Zakon o zaštiti kulturnih dobara čl. II ("Službeni list CG", br. 049/10 od 13.08.2010.)

17 Projekat je tokom 2013/14 finansirala Vlada CG. U projektu su ušešće uzeli stručnjaci iz oblasti kulturne bastine. Kao stručnjak iz ove oblasti, Dobrila Vlahović, bila je član više stručnih timova, među kojima je iza spomen obilježja, koja su poseban segment i njenog samostalnog istraživanja.

I8 Naučni aspekt istraživanja, koji kroz Projekat revalorizacije nije raden, samostalno je započet tokom 2016-18. od strane, Dobrile Vlahović, a sadržajno je povezan sa naučnim istraživanjem, njene doktorske disertacije.

19 Istraživanja u okviru Projekta, tokom 2013/I4. vršila je Dobrila Vlahović, dipl. konzervator i restaurator. Naučni aspekt istraživanja, kroz Projekat nije raden. Rezultati istraživanja, koji daju navedene rezultate, bazirao se na naučnom pristupu, Dobrile Vlahović, koja samostalno vrši istraživanja, sadržajno povezana s naučnim istraživanja doktorske disertacije. 

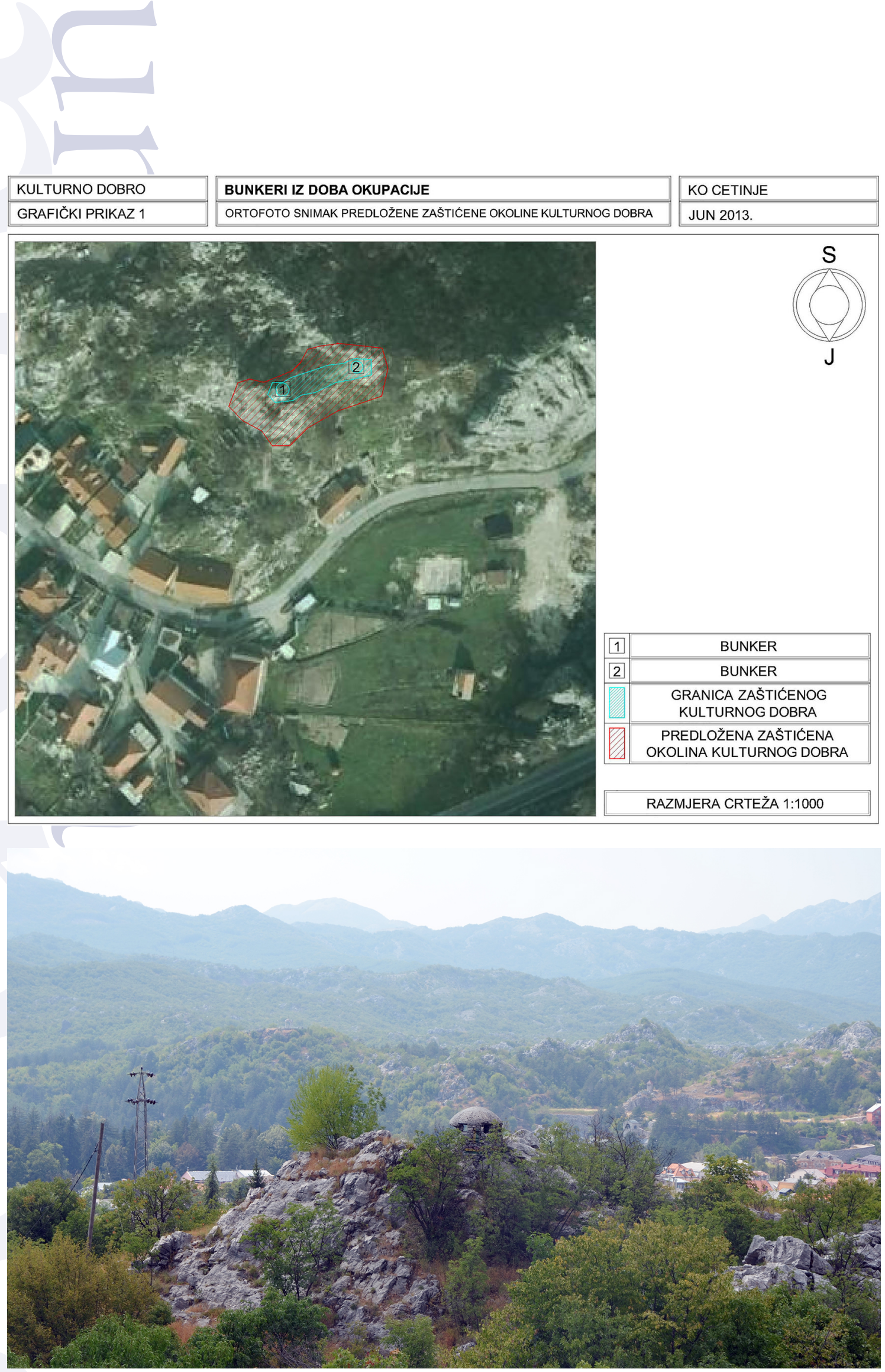


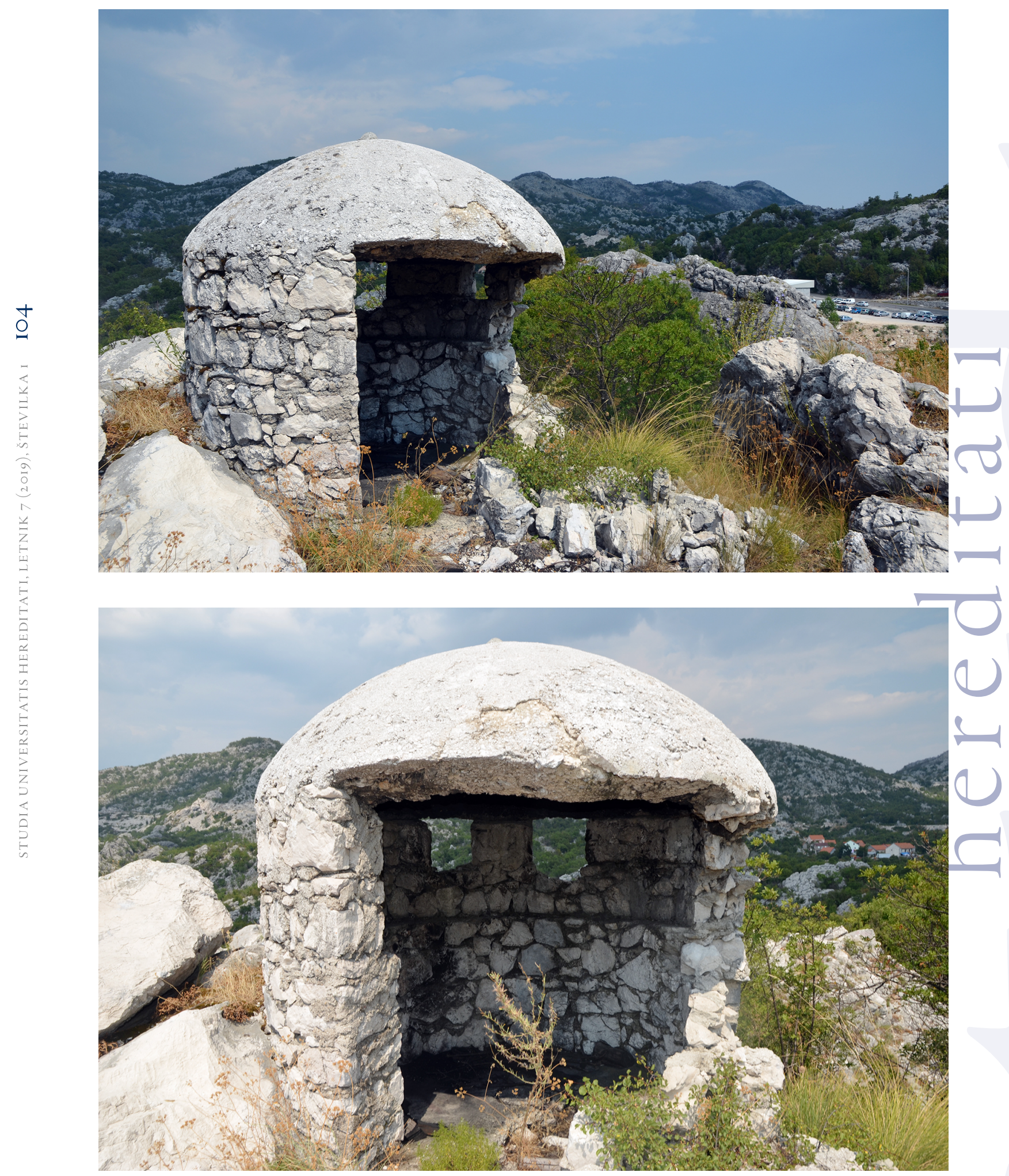


da su bunkeri shodno ranijim propisima ${ }^{20}$ prepoznati kao spomenici NOB-a, i da su uvedeni u Registar nepokretnih spomenika kulture NRCG i time stavljeni pod zaštitu zakona, od 1960. godine. ${ }^{21} \mathrm{U}$ dokumentaciji nijesu pronađeni podaci o njihovoj lokaciji, broju bunkera, stanju i dr. Takođe, ustanovljeno je i da njihova kategorizacija nikada nije vršena, bez obzira što je to bila zakonska obaveza još od 1960. godine. ${ }^{22}$ Jedina informacija bila je, da se nalaze u okolini Cetinja, kao i jedna stara fotografija, na osnovu koje je kasnije ustanovljeno, da prikazuje jedan od bunkera, koji se nalazio u naselju "Bajice", u neposrednoj okolini Cetinja (sl. 3).

Terenskim istraživanjima ${ }^{23}$ evidentirane su postojeće lokacije bunkera i jedna lokacija, za koju se pouzdano vjeruje da se na njoj nalazio jedan od bunkera, njihovo stanje i opšte karakteristike, a kroz rezultate koji su dobijeni, analiziran je i odnos lokalne zajednice.

\section{Lokacija i opšte stanje}

Lokacija "Bajice", se nalazi cca $2 \mathrm{~km}$, od uže gradske zone (GPS - 42 $23^{\prime} 18.37^{\prime \prime} \mathrm{N}$ I $8^{\circ} 55^{\prime} 53.59$ ”). Pouzdano se vjeruje $\mathrm{e}^{24}$ da je na njoj postojao jedan od bunkera (sl. 3), koji je prema saznanjima dobijenim od lokalnog stanovništva, 70-tih godina XX vijeka urušen.

Lokacija "Kruševo ždrijelo" se nalazi cca I,5 $\mathrm{km}$ od uže gradske zone (GPS - $42^{\circ} 22^{\prime} 40.29^{\prime \prime} \mathrm{N}$ $\left.18^{\circ} 56^{\prime} 2.87^{\prime \prime} \mathrm{E}\right)$. Na njoj su evidentirana dva bun-

Zakon o zaštiti spomenika kulture i prirodnih rijetkosti NRCG I949.

21 Rješenje o stavljanju pod zaštitu br. 276/60 od 22.04.1960. godine Rješenje o uvođenju u Registar br o8-709/1 od 4.06.1962. godine; Broj registra: 386; Knjiga II (druga); Strana 369-370; Broj Dosijea: 386/D-NR

22 Prema tadašnjim propisima Zakonom o zaštiti spomenika kulture (Službeni list NRCG br.36/60) i Pravilnikom o registrovanju spmenika kulture u NRCG čl. i 4. (Službeni list NRCG br.9/6I) kategorisani su kao: Spomenici od izuzetnog značaja - I kategorija; spomenici od velikog značaja - II kategorija i značajni spomenici - III kategorija; (ustanovljena je vrsta i kategorija tadašnjih spomenika kulture, što nije bio slučaj sa spomen obilježjima koja su imala taj status).

23 Isto kao i9.

24 Vjerovanje se zasniva na uporednoj analizi stare fotografije, koja je pronađena u Dosijeu kulturnog dobra (Broj Dosijea: 386/D-NR i lokacije u naselju Bajice, kao i saznanja dobijenih od lokalnog stanovništva. kera, postavljena na uzvišenjima sa kojih se kontrolisao prilaz od Podgorice. Zbog neodržavanja, bunkeri su u lošem stanju (sl. 4, 4a, 4b, 4c).

Lokacija "Zabrde-Depozit" se nalazi cca 4 $\mathrm{km}$ od uže gradske zone (GPS - 4223'18.65” N I $8^{\circ} 55^{\prime} 54.65$ ”E). Na noj su evidentirana dva bunkera, postavljena na uzvišenjima, sa kojih se kontrolisao putni pravac prema Budvi. Okolni teren je zapušten i neodržava se. Jedan od bunkera je stabilan (sl. 5a, 5b, 5c), dok je drugi u veoma lošem stanju.

Lokacija „Đinovo brdo" se nalazi cca $2 \mathrm{~km}$ od uže gradske zone (GPS - $42^{\circ} 22^{\prime} 35.53^{\prime \prime} \mathrm{N}$ I $\left.8^{\circ} 55^{\prime} 57.42^{\prime \prime} \mathrm{E}\right)$. Zbog gustog rastinja i visoke vegetacije, nije bila pristupačna, što upućuje na zaključak da su bunkeri prepušteni sami sebi. Sa udaljenosti cca rkm, zapažene su dvije kupole, što navodi na zaključak, o postojanju dva bunkera na toj lokaciji (sl. 6).

\section{Opšte karakteristike}

Istraživanja upućuju ${ }^{25}$ da se radi o manjim fortifikacionim utvrdama, vojnog karaktera. Kružnog su oblika, prečnika u osnovi, cca 1,50 m, dok sun a dvije lokacije vidni ostaci kvadratne osnove. Zidovi su kameni, visine cca I,45 m, a iznad njih je polukružna kupola, od armiranog betona. (sl. 5b, 6a, 6b). Na kružnim zidovima, vidni su veći ulazni otvori (sl. sb), dok se ispod kupola nalaze dva do četiri manja kvadratna otvora, za koje se pretpostavlja da su u bili u funkciji osmatračnice i mjesta za topovske cijevi (sl. 6b). Pozicije otvora, rađene su namjenski, prema ciljevima, odnosno putnim pravcima.

\section{Šta je istraživanjima zaključeno}

Rezultati istraživanja ${ }^{26}$ ukazuju, da je veći broj bunkera u veoma lošem stanju i da su prepušteni sami sebi; da su djelimično sačuvani elementi po

25 Navedeni rezultati, baziraju se na stručno - naučnom pristupu, Dobrile Vlahović.

26 Istraživanja započeta kroz Projekat revalorizacija kulturnih dobara Crne Gore, broj oI-I239 od 23.04.2013. koji je finansijski podržala Vlada Crne Gore. Dipl. konzervator i restaurator, Dobrila Vlahović je bila član stručnog tima, koji je radio na istraživanjima, u okviru ovog projekta, čiji rezultati nijesu naučno obrađeni i publikovani. U ovom slučaju isključivo se bavila ovim kulturnim dobrom i vršila istraživanja. Kako projekat nije imao naučni karakter, samo- 


\begin{tabular}{|l|}
\hline KULTURNO DOBRO \\
\hline \hline GRAFIČKI PRIKAZ 2 \\
\hline
\end{tabular}
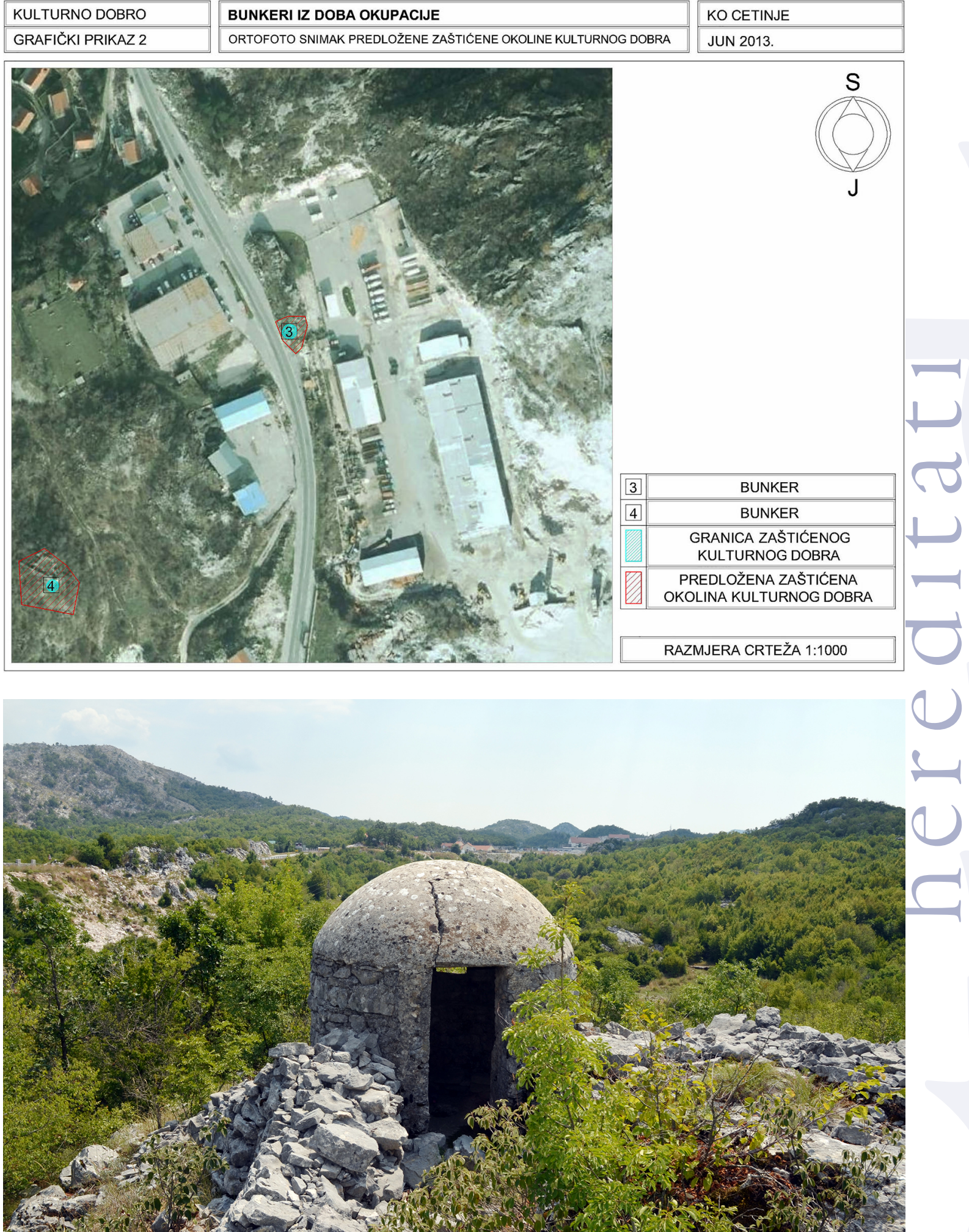


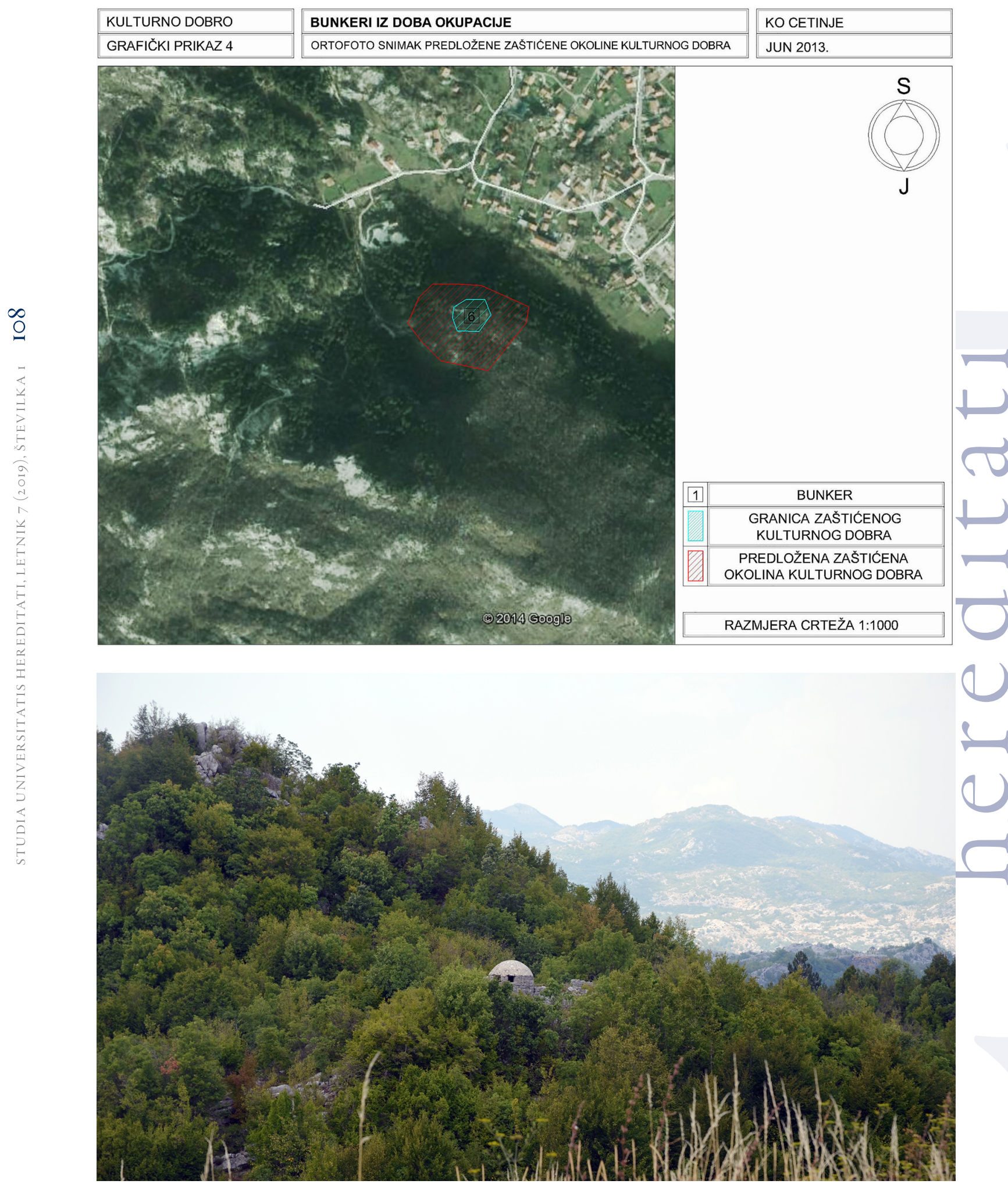


kojima su prepoznatljivi; da bez obzira na ulogu koju su imali tokom okupacije, predstavljaju svjedočanstva o događajima iz istorijskog perioda, značajnog za Cetinje i Crnu Goru; da svjedoče o istorijskom periodu Cetinja i Crne Gore; da zbog specifične arhitekture, lokacije i gradivnog materijala, imaju arhitektonski, pejzažni i ambijentalni značaj u okviru grada Cetinja. ${ }^{27}$ Zbog svega navedenog po prvi put je predloženo, da se kategorizuju, kao nepokretno kulturno dobro od nacionalnog značaja i uvrsti u grupu kulturno-istorijskih objkata - memorijalni objekti. ${ }^{28}$

Zbog veoma lošeg stanja, glavni cilj je sanacija, svih bunkera, sa neposrednim okruženjem, (konzervacija, restauracija, anastiloza i dr.) uz obavezu poštovanja konzervatorskih uslova izdatih od službe zaštite; obezbjeđivanje pristupačnosti, izrada signalizacije, valorizacija, prezentacija u turističke svrhe, kao i korporacija ovog zaboravljenog obilježja sa ostalim segmenatom kulturne baštine i uključivanje u turističku ponudu Prijestonice Cetinje i šire.

\section{Društveni odnos}

Cetinje je grad, koji u sebi nosi slobodarski duh i koji je zbog zasluga u toku NOR-a odlikovan ordenom narodnog heroja. ${ }^{29} \mathrm{U}$ Crnogorskom društvu, naročito na Cetinju danas nema recenzije sjećanja na period NOR-a, naprotiv, izražen je pozitivan društveni odnos. Na to upućuju brojni spomenici i spomen obilježja, o kojima se brine i koji se posjećuju povodom proslava značajnih jubileja, naročito I3. jula, Dana državnosti Crne Gore.

stalno je nastavila sa naučnim istraživanjima, koja doprinose novim saznanjima, valorizaciji i prezentaciji ove vrste kulturnih dobara.

$27 \quad$ Kriterijumi za utvrdivanje kulturne vrijednosti dobra su propisani Zakonom o zaštiti kulturnih dobara, ("Službeni list CG", br. 049/ı od 13.08.2010.), koji su bili osnov za provjeru kulturne vrijednosti tokom postupka revalorizacije.

28 Na osnovu svojstava, osobenosti i značaja shodno čl. 6, 7, 8 i 9 Pravilnika o bližim kriterijumima i postupku za utvrdivanje kulturne vrijednosti, predlaženo je da se, Bunkeri iz doba okupacije u II svjetskom ratu, u skladu sa članom 34 Zakona o zaštiti kulturnih dobara, kategorizuju kao kulturno dobro od nacionalnog značaja. (Članica stručnog tima, koja je predložila kategorizaciju, bila je dipl. konzervator i restaurator, Dobrila Vlahović, a tehnički tim, arh. Milica Jakić i Filip Krgović).

29 Vidi 3.
O tome prenose i brojni mediji. Tako Dnevne novine Vijesti od I3. jula 2012. pišu, da su predstavnici UBNOR-a Cetinje i Prijestonice Cetinje, položili vijence na spomen ploču u Humcima i na spomen-obilježje na Gorniču. ${ }^{30}$ Takođe, i gradska Uprava Cetinja, I8. jula 2013. saopštava, da se na Cetinju održava sjednica Predsjedništva Saveza udruženja boraca Narodnooslobodilačkog rata i antifašista Crne Gore, ${ }^{31}$ a I4. maja 2019, saopštava da je predsjednik Đukanović toga dana primio delegaciju SUBNOR-a antifašista Crne Gore. ${ }^{32}$ Takođe, Cetinjski list od I4.07.2019. godine, piše da je okviru obilježavanja i3. jula - Dana državnosti Crne Gore, na ulicama Cetinja održan "Veliki crnogorski marš" u organizaciji Evropskog pokreta za vladavinu prava, kada je položeno cvijeće na Spomen kosturnicu posvećenu I2O strijeljanih rodoljuba toga kraja tokom NOR-a. Sve ovo ukazuje na pozitivan društveni odnos prema spomenicima NOB-a.

Međutim, šta je sa simbolima koje je ostavila okupatorska vojska na Cetinju, Bunkerima iz doba okupacije u II svjetskom rata. Njihovo loše stanje i odsustvo brige, nameće brojna pitanja. Ako se uzme u obzir njihov status, sa aspekta sistema zaštite, prepoznati su kao značajan segment crnogorske kulturne baštine. Sistem upućuje na javni interes kulturne baštine i obavezuje vlasnike i držalace na njihovu zaštitu očuvanje i unaprjeđenje stanja-(Zakon 2010). Međutim, rezultati istraživanja ukazuju na loše stanje, odsustvo integralne zaštite, neuključenost u turističku ponudu grada koja je, kada su u pitanju ostali segmenti kulturne baštine, na veoma visokim nivou.

Bez obzira na promišljanja, zakon obavezuje sve strukture društva, državu da štiti, a građene da čuvaju svoju kulturnu baštinu (Ustav 2007), naročito iz razloga što bunkeri predstavljaju segment crnogorske kulturne baštine sa statusom kulturnog dobra. Ukoliko se ne sprovedu predložene mjere njihove sanacije, integralne zaštite i valorizacije, potpuno će nestati, rijetki primjeri

\footnotetext{
30 Spomenici iz NOB-a: https://www.vijesti.me/vijesti/politika/ i-na-cetinju-obiljezen-dan-drzavnosti

fokuspress.com > u-fokusu > 807 Im

32 I3 jul, 2019. https://www.glasamerike.net/a/
} 
manjih vojnih fortifikacija koje u Crnoj Gori nalazimo samo na teritoriji Cetinja.

\section{Zaključak}

Cetinje kao grad heroj je pošteđeno nenaučne destrukcije antisocijalističkog narativa. Većina socijalističkih spomenika su sačuvani, u školama se i dalje uči o narodno-oslobodilačkoj borbi, a parkovi (Vlahović 20ı2, 52) ulice, škole i Cetinja i dalje nose nazive, koji podsjećaju na taj period. ${ }^{33}$ Međutim, osvrtom na rezultate istraživanja, nameće se pitanje odnosa lokalne zajednice, isključivo prema, Bunkerima iz doba okupacije u Drugom svjetskom ratu.

Njihovo stanje, odsustvo brige i integralne zaštite upućuje na različita tumačenja. $\mathrm{Na}$ jednoj strani, slave se i poštuju tekovine revolucije i NOR-a, dok na drugoj strani vidni su, istina rijetki primjeri, koji su prepušteni sami sebi.

Na pitanje, da li su prihvaćeni, rekli bi da jesu, još 1960. godine, kada su zakonom zaštićeni i stekli status nepokretnog spomenika kulture, a da li su zaboravljeni, najbolje svjedoči njihovo stanje, koje je izazvalo veliku zainteresovanost. Ako se uzme u obzir njihov status, sa aspekta sistema zaštite, prepoznati su kao značajan segment crnogorske kulturne baštine. Sistem upućuje na javni interes kulturne baštine i obavezuje vlasnike i držaoce na njihovu zaštitu, očuvanje i unaprjeđenje stanja, kako bi se sačuvali za buduće generacije, kao istorijski kontekst, jedog perioda, što je obaveza svih struktura društva. Ovo je naročito važno u trenutku kada evropska praksa pokazuje, sve veću zainteresovanost turista za spomenike NOR-a, tako da postepeno postaju brend i značajan segment kulturnog turizma, i kao takvi mogu dati važan doprinos ekonomiji lokalnih zajednica.

Ovim radom se pokušalo ukazati na stanje i odnos prema jednom kulturnom dobru, u društvu koje čuva i baštini pozitivan stav prema tekovinama NOR-a, gdje najveći dio lokalne zajednice tekovine NOR-a ističe kao osnov crnogorske državnosti, (Stanišić 2005, 80-90; Ičević 2015, 97-IOO), naglašavajući da je to osnova postojanja

33 "Trg Revolucije"; ul." Jovana Tomaševiča”; "Bulevar crnogorskih junaka"; OŠ "Lovćenski partizanski odred;" današnje Crne Gore i glavna zaštita crnogorskog građanskog društva, čiji su temelji, baš na Cetinju.

\section{Sažetak}

Cetinje je manji grad, koji pripada Južnoj regiji Crne Gore. Nekadašnji centar crnogorske države, danas je kulturno-istorijska i duhovna Prijestonice Crne Gore. O tome svjedoči bogata kulturna baština iz različitih epoha, koja podsjeća na njegov identitet, istorijat i razvoj. Poseban segment kulturne baštine Cetinja su spomen obilježja, koja simbolizuju događaje i žrtve Drugog svjetskog rata, zbog čega su zakonom zaštićena i imaju status kulturnog dobra. Najviše njih, podignuto jecu poslijeratnom periodu, kao odraz društveno političkih okolnosti, koje su afirmisale tekovine Narodnooslobodilačke borbe, težeći da se osnaži kolektivno sjećanje i da se ne zaboravi.

Međutim, kada govorimo o Crnoj Gori i ovom periodu, na Cetinju se nailazi i na rijetku vrstu spomenika iz ovog perioda, koja je takođe zakonom zaštićena i ima status kulturnog dobra, to su, Bunkeri iz doba okupacije u Drugom svjetskom ratu. Sagradio ih je okupator, u cilju represije prema gradu i stanovništvu. Danas podsjećaju na teške dane okupacije Cetinja. Iako su zakonom zaštićeni, do sada nijesu dovoljno istraženi i valorizovani, i o njima se veoma malo zna.

Na temeljima istraživanja, u radu je predstavljen istorijski kontekst njihovog nastanka i zaštite, lokacije na kojima se nalaze, kao i broj evidentiranih bunkera i njihovo stanje, a podsjeća se i na odnos lokalne zajednice, prema ovoj vrsti kulturnih dobara. Rezultati istraživanja imaju pozitivne efekte, u smislu novih saznanja i mogu doprinijeti budućim aktivnostima usmjerenim na njihovoj valorizaciji, prezentaciji, kao i integralnoj zaštititi, kao neodvojivom segmentu kulturne baštine Prijestonice Cetinje.

\section{Summary}

Cetinje is a smaller town, which belongs to the Southern region of Montenegro. Formerly the center of the Montenegrin state, today it is the cultural, historical and spiritual Capital of Montenegro. This is confirmed by the rich cultural heritage from different epochs, reminiscent of its identity, history and development. A special segment of the cultural heritage of Cetinje are the 
memorials, which symbolize the events and victims of World War II, which is why they are protected by law and have the status of a cultural property. Most of them were erected in the post-war period, as a reflection of the social and political situation, which affirmed the achievements of the National Liberation War, seeking to strengthen the collective memory with the aim of not forgetting.

However, when we talk about Montenegro and this period, there is a rare type of monument from this period in Cetinje, which is also legally protected and has the status of a cultural property, Bunkers from the time of occupation in World War II. They were built by the occupier, for the purpose of repression against the city and population. Today is a reminder of the difficult days of the occupation of Cetinje. Although protected by law, so far they have not been sufficiently researched and valorized and very little is known about them. On the basis of the research, the article presents the historical context of their origin and protection, their locations, as well as the number of bunkers and their condition, as well as the relationship of the local community to this type of cultural property.

The results of the research have positive effects, in terms of new knowledge and can contribute to future activities aimed at their valorisation, presentation, as well as integral protection, as an inseparable segment of the cultural heritage of the Capital of Cetinje.

\section{Literatura i izvori}

Dragićević, R. I956. “Cetinje-Istorijski razvitak.”Enciklopedija Jugoslavije II.

Zagreb: 372-373.

Kirn, G., R. Burghardt Robert. 2012. "Jugoslovenski partizanski spomenici. Izmedu revolucionarne politike $i$ apstraktnog modernizma-jugo" Link. pregled postjugoslovenskih istraživanja. // leto 20I2. // god. 2. // br. I //.

Ičević, D. 2015. "Crnogorska nacija-

Trinaestojulski ustanak-nova potvrda crnogorskog identiteta”. Beograd: drugo izdanje Forum za etničke odnose. (2015): $60-100$.
Martinović, D.1983: "Cetinje Grad heroj spomenici $N O B$-a i narodne revolucije.” Prosveta. Požarevac: 232.

Martinović, D.J., C. Marković. 1992. "Studija o spomenicima i spomen obilježjima Cetinja.” Obod, Cetinje.

Martinović, N. S.1954. Iz okupiranog Cetinja - Omladinski pokret, XIII/Ig54, br. 22, 29. novembar.

Ministarstvo kulture. 2009. Menadžment plan Istorijskog jezgra Cetinja. Vlada Crne Gore sjednica od 28.05.2009. godine, (revidovan, 2014): 29-30.

Petrović, P. Nj. 1977. Gorski vijenac.Luča mikrokozma. Beograd: Prosveta Beograd / Obod Cetinje.

Prekić, A. 2015. “Tradicija NOB-a u crnogorskom društvu 1945-1955." MATICA, br. 64, zima 2015. (279-312)

Stanišić, M. 2005. "Dubinski slojevi Trinaestojulskog ustanka u Crnoj Gori.” Istorijski institut Crne Gore, Podgorica.

Širok. K. 20I2. "Identitete, zgodovina in dediščina prostora - prakse spominjanja ..., in komemoracije na Goriškem v XX. stoletju." Acta Histriae. 20. 2012: 63I-646.

Vlahović, D. 2012. FUTUROPA /Council of EUROPE. Public parks of historic town of Cetinje, Montenegro no. 3 (2012): 52.

Vujović, D. 1966. "Cetinje u danima 13-julskog ustanka.” Istorijski zapisi, god. XIX, knj. XXIII, sv. 4. 1966.

\section{Arhivski izvori}

Dokumentacija Uprave za zaštit kulturnih dobara Crne Gore (UZKD CG).

Pravilnik o bližim kriterijumima i postupku utvrđivanja kulturne vrijednosti dobra. Službeni list Crne Gore (20II), Br. 4I/II, 2orr. Podgorica

Rješenje o stavljanju pod zaštitu, (Bunkeri iz doba okupacije u Drugom svjetskom ratu") Br. 276/60. 22.04.1960. Cetinje. ${ }^{34}$

34 Nije objavljeno u službenom listu, jer 1960. nije bila obaveza, tek nakon 2oro. je to zakonska obaveza ali to je za sada jedino rješenje. 
Dosije "Bunkera iz doba okupacije u Drugom svjetskom ratu" (1960), Br. 386/D-NR. knj. II, 369-370. Uprava za zaštitu kulturnih dobara CG, Cetinje.

Rješenje o uvođenju u Registar spomenika kulture NRCG. Cetinje.

Uprava za zaštitu kulturnih dobara Crne Gore (UZKD CG)._Registar kulturnih dobara Crne Gore -Glavna knjiga nepokretnih kulturnih dobara. god.1960/6r. knj. I-IV. I960/6r.Cetinje

Ustav Crne Gore. 2007. Službeni list Crne Gore (2007) Br.I/2007. (ćl. 78.) Podgorica.

Zakon o zaštiti kulturnih dobara 20 Io.

Službeni list Crne Gore (2010), Br. 049/ıO.

\section{Internetni izvori}

http://www.cetinje.me/ (I.9.2019.)

https://www.vijesti.me (I.9.2019.)

fokuspress.com (1.9.2019.)

https://www.glasamerike.net/a (I.9.2019.)

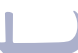

-
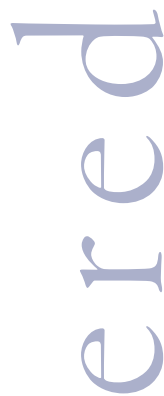


\title{
Povezovanje turizma in kreativnih industrij pri oživljanju opuščene industrijske dediščine skladišča Monfort
}

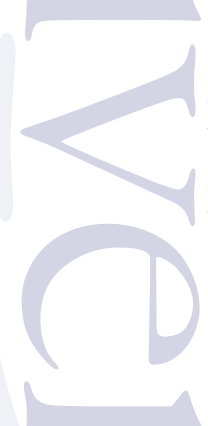

\author{
Gorazd Sedmak \\ Fakulteta za turistične študije - Turistica, Univerza na Primorskem \\ Aleksandra Brezovec \\ Fakulteta za turistične študije - Turistica, Univerza na Primorskem \\ Neža Čebron Lipovec \\ Fakulteta za humanistične študije, Univerza na Primorskem \\ Ana Plestenjak \\ Arhej, d. o. o.
}

Ştudija izhaja iz predpostavke o visoki kulturno-zgodovinski turistični privlačnosti objekta in destinacije ter priložnostih za skupno trženje turizma in kreativnih industrij. Trženjski model je zasnovan na sinergiji obeh dejavnosti, povezanih v komplementarno in trajnostno naravnano poslovno enoto, ki uposteva konkretne potrebe vseh deležnikov. Posebnost tega trženjskega modela je v prepletu aktivnosti privabljanja turistov (eksterno trženje) z aktivnostmi povezovanja notranjih deležnikov - ponudnikov kreativnih storitevy objektu (interno trženje). Model predstavlja torej enovit strateški okvir, znotraj katerega se lahko predstavniki kreativnih industrij povezujejo in povezani nastopajo na turističnem trgu, pri tem pa suvereno oblikujejo svoje specifične vizije, cilje in trženjske strategije.

Ključne besede: turizem, kreativne industrije, trženje, industrijska dediščina skladišča Monfort

The study assumes that the cultural-historical character of the site and destination possesses a high degree of attraction for tourism and that a joint marketing of tourism and creative industries is a potential. The model is based on the synergy between the two activities, connected into a complementary and sustainability-bound business unit that considers the actual needs of all the stakeholders involved. Specificity of the presented marketing model lies in the intertwining of activities to attract tourist (external marketing) and activities aimed at connecting the inner stakeholders, namely the providers of the creative industry service at the site (internal marketing). Hence, the model represents a comprehensive strategic framework, within which the representatives of creative industries can enter cooperate and team-up in the presentation on the tourist market, while also assertively design their own specific visions, goals and marketing strategies.

Keywords: tourism, creative industry, marketing, industrijal heritage of Monfort warehouse

\section{Opredelitev kreativnih industrij in njihove povezave s turizmom}

$\mathrm{P}$ ojem »kreativne industrije $\ll$ je relativno nov, zato so definicije še raznolike. Med splošno sprejetimi je opredelitev kreativnih industrij kot dejavnosti, ki proizvajajo kulturne dobrine in storitve. Natančneje so v Unescovi konvenciji iz leta 2005 opredeljene kulturne industrije, in sicer kot industrije, ki »združujejo ustvarjanje, proizvajanje in komercializacijo vse- bin, ki so kulturne narave; te vsebine so običajno zaščitene $\mathrm{z}$ avtorskimi pravicami in lahko imajo obliko blaga ali storitev«. Unescov dokument v nadaljevanju izpostavi kot pomemben vidik kulturnih industrij spodbujanje in ohranjanje kulturne raznolikosti ter zagotavljanje demokratičnega dostopa do kulture (UNCTAD 2010, 5). Z uveljavljanjem pojma kreativnih industrij pa se pri pojmovanju kulturnih industrij zgodi premik od pretežno negospodarskih h komercialnim kulturnim dejavnostim (UNCTAD 20ı, 
6). Medtem ko kulturne industrije proizvajajo in distribuirajo dobrine ali storitve, ki utelešajo ali posredujejo kulturno izražanje ne glede na komercialno vrednost (npr. scenske umetnosti, likovne umetnosti, kulturna dediščina, tudi film, novi mediji, glasba, knjige in tisk), imajo kreativne industrije kulturno razsežnost, ker uporabljajo kulturo kot vložek (npr. arhitektura in oblikovanje s podsektorji, kot so grafično in modno oblikovanje ali oglaševanje) (EU Comission 2010, 5). Skladno s tem je Evropska komisija opredelila tipologijo kreativnih industrij (FORA 20Io) (Slika I). Po tej tipologiji so kreativne industrije $\mathrm{v}$ najožjem pomenu tiste aktivnosti, pri katerih je osrednji produkt rezultat umetniške aktivnosti. Širši pomen vključuje med kreativne industrije tudi tiste dejavnosti, $\mathrm{v}$ katerih osrednji produkt sicer ni neposredna posledica kulturne dejavnosti, ima pa določene kulturne značilnosti. V najširšem smislu so pa v kreativne industrije vključene tudi panoge, katerih ekonomske aktivnosti temeljijo na umetnosti in kulturi. Primer takšne panoge je turizem (FORA 20IO).

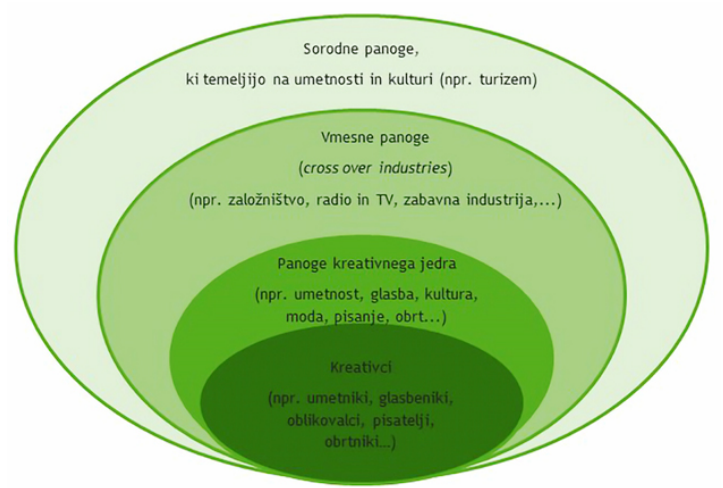

Slika I: Tipologija kreativnih industrij po FORA (2010), prirejeno v slovenskem jeziku (vir: Plestenjak in soavtorji 2018).

Navedena tipologija je omogočila razumevanje neposredne povezave kreativnih industrij s turizmom, zlasti s segmentom kulturnega turizma, ki svoje produkte in motivatorje utemeljuje na stvaritvah kreativcev.
Strokovnjaki pripisujejo kreativnim industrijam gonilno moč pri spodbujanju širše ekonomske rasti. Utemeljitev koncepta kreativnih industrij, Richard Florida skozi svoje temeljno delo The Rise of the Creative Class (2002) sporoča, da sposobnost in praksa kreiranja novih zamisli in stalnih izboljšav ultimativno dviguje produktivnost in življenjski standard. V študiji Cultural times (CISAC 2015) je ekonomski pomen kreativnih industrij tudi finančno ovrednoten: $\gg$ Kulturne in kreativne industrije $s$ prihodkom 2,250 milijard USD zagotavljajo $3 \%$ svetovnega BDP in zaposlujejo 29,5 milijonov ljudi (I \% delovno aktivne svetovne populacije) $)_{\ll}$ (CISAC 20I5). Študija, ki je bila predstavljena na sedežu UNESCA v Parizu leta 2015, pojasnjuje prispevek kreativnih industrij h globalnemu gospodarstvu ob predpostavki, da če želimo izkoristiti polni potencial kreativnih industrij, morajo biti ustvarjalci pravično plačani, da lahko nadaljujejo s svojim prispevkom h kulturi in posredno h gospodarstvu. Politični odločevalci morajo torej spodbuditi pravičen sistem prenosa vrednosti, ki bo zagotovil ustvarjalcem in s tem kreativnim industrijam sorazmeren tržni delež in pravično poplačilo za izkoriščanje njihovih del v gospodarskih panogah, tudi v turizmu.

Primer sistemske spodbude prenosa vrednosti je čezmejni projekt REFREsh - Rural Revitalisation for Cultural Heritage, izvajan v okviru programa Interreg Central Europe (20172020), s katerim Občina Piran sledi usmeritvam Republike Slovenije na področju uveljavljanja kreativnih industrij po regijah, ki bodo predstavljene v nadaljevanju. Osrednji predmet raziskave v okviru navedenega predmeta je skladišče soli Monfort v Portorožu. Po investiciji v prenovo tretje kampate (od petih) v letu 2019 je občina poverila trženje prostora Turističnemu združenju Portorož. Že doslej je prihajalo do spontanega povezovanja turizma in kreativnih industrij; z novimi prostorskimi možnostmi in sistematičnim spodbujanjem povezovanja oz. vključevanja kreativnih industrij $\mathrm{v}$ turistično ponudbo pa so se že pokazali dodatni sinergijski učinki, ki bodo spodbudili nadaljnji razvoj kreativnega de- 
lovanja v občini in obogatili turistično ponudbo destinacije. Ključna poteza projekta je vključevanje vseh relevantnih deležnikov v oblikovanje rešitev, katerim vsebinam naj bi se namenili prostori.

\section{Ukrepi na področju povezovanja} kreativnih industrij s turizmom v Sloveniji

V Sloveniji še nimamo celostne strategije za razvoj kreativnih industrij, prav tako na nacionalni ravni ne obstaja institucija kot osrednje jedro spodbujanja kreativnega sektorja, čeprav so se prizadevanja na tem področju začela že pred dobrim desetletjem. Leta 2008 je namreč vlada RS ustanovila 9. razvojno skupino za kreativne industrije, katere naloga je bila pripraviti vsebinska izhodišča državne strategije za uspešnejše uveljavljanje kreativnega sektorja (oblikovanje, arhitektura in trženjsko komuniciranje) pri ustvarjanju dodane vrednosti slovenskega gospodarstva. Priporočila 9. razvojne skupine predstavljajo prvi dokument, ki je osredotočen na kreativne industrije in ugotavlja, da Slovenija na tem področju zaostaja, čeprav osnovna strokovna infrastruktura obstaja. Problemi se pojavljajo, ker je infrastruktura slabo povezana s kreativnimi industrijami ter ker financiranje ni programsko naravnano in ne daje motivacije za povezovanje. $\mathrm{Z}$ namenom, da bi presegli to stanje, je leta 20I I Ministrstvo za kulturo RS pripravilo medsektorsko preverbo področja in izdalo knjižico za popularizacijo pojma kreativnih industrij (Breznik in soavtorji 20II). Pri definiciji so se avtorji oprli na metodologijo Eurostata in definicijo Evropske komisije, ki med drugim povezuje kreativne industrije tudi s turizmom.

$\gg$ V tem kontekstu postajajo ob tradicionalno izpostavljenih in cenjenih vrstah umetnosti, zlasti tistih, ki temeljijo na jeziku (leposlovje, dramsko gledališče, vokalna glasba), vse bolj pomembne tiste vrste umetnosti oz. kulture, ki neposredno vplivajo na razvoj države in zlasti gospodarstva ter prispevajo tudi $\mathrm{k}$ rasti BDP. Gre za kreativne industrije, od industrijskega in grafičnega oblikovanja, AV produkcije in storitev, intermedijskih umetnosti do kulturnega turizma in nesnovne kulturne dediščine oz. veščin, ki omogočajo izdelavo unikatnih proizvodov z visoko dodano vrednostjo « (Breznik Močnik in soavtorji 20II).

Leta 2018 je Ministrstvo za kulturo RS izoblikovalo Strategijo kulturne dedisčine za obdobje 2018-2026, v kateri je prav tako izpostavilo povezanost kreativnih industrij in turizma. $\mathrm{V}$ strategiji je kot razvojna usmeritev navedeno »Spodbujanje razvoja trajnostnega kulturnega turizma, kreativnih industrij in drugih novih produktov in storitev $\mathrm{z}$ uporabo dediščinskih virov«. Dediščina je prepoznana kot tista, ki je >skupaj z dejavnostmi, ki jih generira, izjemno dragocen vir za turistično-gospodarski sektor in kreativne industrije « (Direktorat za kulturno dediščino 2018, 17-18). Med ukrepi strategije sta dva eksplicitno naslovljena na kreativne industrije in turizem:

- Podpora aktiviranju dediščine za spodbujanje kulturnega turizma, kreativnih industrij in drugih načinov uporabe dediščinskih virov;

- Izboljšanje ozaveščenosti o pomenu dediščine pri zaposlenih $\mathrm{v}$ turizmu in kreativnih industrijah ter njihovo usposabljanje.

- V naboru dejavnosti tako najdemo konkretne primere, ki ponovno neposredno in posredno odpirajo možnosti za razvoj in povezovanje kreativnih industrij s turizmom:

- Vključevanje dediščine v strategije razvoja turizma Slovenije;

- Izvedba pilotnih projektov aktiviranja dediščine, ki prispevajo k razvoju trajnostnega turizma, kreativnih industrij in drugih novih produktov in storitev, povezanih $\mathrm{z}$ dediščino;

- Pri promociji turizma na določenem območju predstavljanje lokalne dediščine na vključujoč način, ki bo zagotavljal koristi tudi lokalnemu prebivalstvu in ne bo ogrožal dediščine; 
- Oblikovanje dediščinskih blagovnih znamk za trženje na področju turizma in kreativnih industrij.

Nazadnje je istega leta pod okriljem Muzeja za arhitekturo in oblikovanje, v okviru Operativnega programa za izvajanje evropske kohezijske politike v obdobju 20I 4-2020, začela delovati interdisciplinarna platforma Center za kreativnost (CzK). Naloga centra je, da »povezuje, promovira, predstavlja in podpira razvoj vseh značilnih področij kreativnega sektorja (KKS) v Sloveniji. S svojimi programi spodbuja opolnomočenje potencialov družbene in ekonomske vrednosti sektorja ter ga aktivneje povezuje $\mathrm{z}$ gospodarstvom, znanostjo, izobraževanjem in drugimi sektorji $\ll(\mathrm{CzK}$ 2019). Center, ki je finansiran s strani Evropskih kohezijskih skladov, ima v trenutnem stanju dejansko vlogo osrednje organizacije za KKI v Sloveniji. Čeprav nima formalno poverjenih nalog koordinacije, v okviru CZK nastajajo referenčni temeljni dokumenti in kot tudi primeri dobrih praks.

Izpostavljeno trojno razmerje med kulturnim turizmom, kulturno dediščino in kreativnimi industrijami predstavlja pomembno izhodišče razvoja kreativnih scen tudi v Obalnokraški regiji. Kreativne industrije so prav v tej regiji najbolj povezane s turizmom, saj se na tem območju že tradicionalno ustvarja četrtina celotnega turizma Slovenije.

\section{Razvojni potenciali kreativne scene skladišča Monfort v Portorožu}

Med turističnimi destinacijami Obalno-kraške regije ima vodilno mesto piranska občina s Portorožem kot osrednjim slovenskim letoviščem, ki na leto pritegne 500.000 gostov ter ustvari 1,5 milijonov nočitev (povprečje zadnjih pet let; vir: SURS 20I8). V sklopu projekta REFREsh smo preverjali tržne potenciale vključevanja kreativnih industrij $\mathrm{v}$ turizem pri oživljanju skladišč soli Monfort v Portorožu. V okviru projekta je Občina Piran, poleg že razvitega terciarnega sektorja (turizem), pristopila k spodbujanju kreativnih industrij tudi v sekundarnem sektorju, in sicer v okviru tradicije pridobivanja soli (rudar- jenje), ki je značilno za to območje. Razvoj turizma je namreč $\mathrm{v}$ Portorožu že tradicionalno povezan s solinarstvom, saj se je turizem na tej destinaciji pojavil prav skozi razvoj zdraviliških storitev $\mathrm{z}$ uporabo stranskih produktov pridobivanja soli. Tako se je portoroški samostan San Lorenzo (sedanja lokacija hotela Metropol) že v 13. stoletju omenjal kot zdraviliški kraj, ki je slovel po zdravilnih učinkih solinskega blata in slanice iz piranskih solin. Sodobna turistična dejavnost se je v Portorožu začela razvijati v drugi polovici 19. stoletja, ko so kraj tržili kot privlačno kopališko destinacijo in v luksuznih vilah ponujali kapacitete za turistične namestitve. Kopališču in prvemu hotelu, ki sta bila v Portorožu zgrajena leta I89ı, so hitro sledile nove investicije in leta 1897 je bil Portorož (Porto Rose presso Pirano, natančneje območje od Metropolovega griča do Bernardina) uradno razglašen za klimatsko zdravilišče. Razcvet je portoroški turizem začel doživljati po izgradnji hotela Palace leta I9ı in $\mathrm{z}$ vzpostavitvijo mednarodne letalske povezave (hidroport ob Monfortu) (Gombač in Brezovec 2007,43$)$. Turistični razvoj območja sta začasno prekinili obe svetovni vojni, vendar se je v obdobju po priključitvi Jugoslaviji in s tem Sloveniji, razvoj portoroškega turizma intenzivno stopnjeval. Po zasnovi arhitekta Eda Mihevca in temeljiti prenovi kraja v letih $1965-76$ je postal Portorož vodilna turistična destinacija in eden od stebrov slovenskega turizma, kar je ostal vse do danes. Po aktualnem razvojnem načrtu (Strategija razvoja turizma v občini Piran do leta 2025; Lesjak, Brezovec in Fabjan 2018) se portoroški turizem usmerja $\mathrm{k}$ trajnostnemu razvoju, pri čemer se v ospredje postavljata kultura in dediščina kraja. V smislu kulturno-kreativnih industrij se v Portorožu nadaljujejo tradicije glasbenih, filmskih in oglaševalskih festivalov, ki so se skozi desetletja že intenzivno vpeli v turizem. Prav tako je turistično aktivno delovanje sečoveljskih solin, ki skozi znamko tako Krajinskega parka Sečovlje kot podjetja Soline dodaja novo vrednost solinskim izdelkom in turističnim storitvam v Portorožu. $S$ tematskim oživljanjem skladišč soli Monfort bi se lahko trženje 


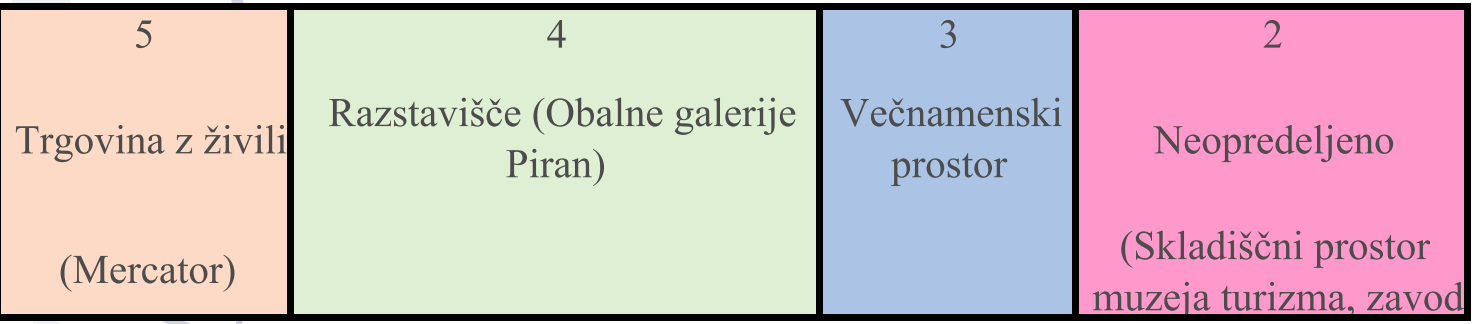

Slika 2: Trenutna raba prostorov v objektu Monfort (vir: Plestenjak in soavtorji, 20I8).

izdelkov in storitev razširilo tudi na druge kreativne industrije $\mathrm{v}$ kraju in s tem pospešilo kulturni turizem. V ta namen je bila skozi projekt REFREsh opravljena valorizacija skladiščne stavbe Monfort.

\section{Metodologija valoriziranja objekta $v$ kulturno turistične namene}

$\mathrm{Z}$ namenom pridobivanja nabora idejnih rešitev glede vsebin je bilo v sklopu projekta organiziranih več delavnic, fokusnih skupin in sestankov $s$ predstavniki različnih skupin deležnikov (lokalna skupnost, predstavniki kreativnih industrij, GIZ Portorož), kjer se je zbiralo ideje, izmenjevalo mnenja in stališča ter snovalo možne strateške usmeritve glede vsebin, ki naj bi bile umeščene v objekt, ter sinergij, ki naj bi iz teh izhajale. Predlaganih je bilo več vsebin s področja glasbene ustvarjalnosti (glasbena šola, vadnice za mlade glasbene skupine, snemalni studio, ...), likovne in vizualne ustvarjalnosti (animacija, ročne spretnosti), ustvarjalnosti (animacije, ročne spretnosti ...), športno-rekreativnih aktivnosti (joga, ples, sodobni ples, ...) in družabnega življenja (kartanje, šah, biljard, rojstnodnevna praznovanja otrok ...). Med predlogi je bilo kar nekaj vsebin, ki v občini že obstajajo in katerih podvajanje ne bi bilo smiselno, potencialno težavo pa predstavljajo tudi nekompatibilne aktivnosti oz. vsebine. Za lažje odločanje smo zato opredelili nekaj ključnih kriterijev vključevanja in povezovanja dejavnosti KKI:

- ne podvajanje vsebin, ki že imajo ustrezne pogoje za delovanje,
- kompatibilnost dejavnosti z osnovnim namenom prostorov,

- sorodnost in kompatibilnost vsebin oz. področij delovanja,

- sorodnost poslanstva/vrednot/motivov (raven komercialnih ambicij, vplivati na kakovost življenja v lokalni skupnosti, druženje podobno mislečih ...) nosilcev dejavnosti,

- kraj bivanja/delovanja nosilcev/izvajalcev dejavnosti (prednost imajo lokalni oz. regionalni akterji),

- kompatibilnost potrebnih resursov in možnosti sinergij ter oblikovanja verig vrednosti in

- medsebojna kompatibilnost glede ciljnih skupin uporabnikov.

\section{Kreativne funkcije prostorov $v$ Monfortu}

$\mathrm{V}$ skladišču Monfort, ki je razdeljeno na pet dvoran (kampat), so kreativne industrije že sedaj aktivne. Ena od kampat je namenjena trgovini $\mathrm{z}$ živili, v vseh ostalih kampatah pa se izvajajo programske vsebine, ki jih večinoma izvajajo kreativne industrije.

$\mathrm{V}$ prvi kampati je stalni razstavni prostor Pomorskega muzeja »Sergej Mašera «, Piran. V tej kampati je tudi manjša predavalnica ter info točka. V prizidku so urejene sanitarije. Pomorski muzej »Sergej Mašera« zbira, proučuje in predstavlja pomorsko preteklost slovenskega obalnega področja, slovensko pomorsko preteklost in na pomorstvo vezane gospodarske panoge. V Monfortu predstavlja zbirki Tradicionalno ladjedelništvo in Razvoj vodnih športov. $\mathrm{V}$ info točki je trenutno postavljena razstava 


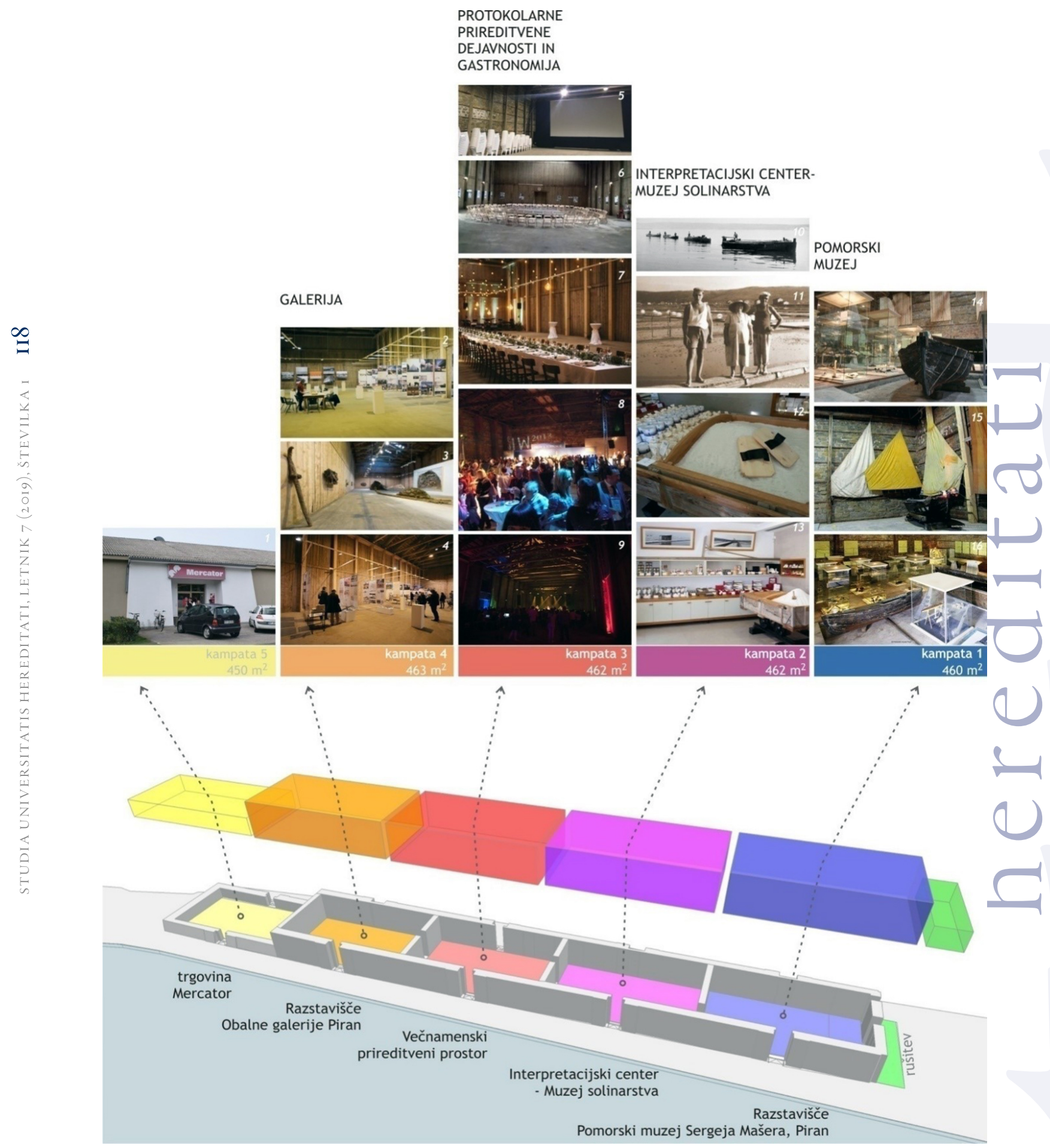

Slika 3: Pregled kreativnih funkcij prostorov v Monfortu (vir: Plestenjak in soavtorji 2018). 
o solinarstvu, kjer je predstavljena tudi zgodovina nastanka skladišč in razvoja območja. V četrti kampati so stalni razstavni prostori Obalnih galerij Piran, osrednje galerijske institucije v Obalno-kraški regiji .

V drugi kampati je bil do nedavnega urejen skladiščni prostor muzeja turizma (zavod Mediteranum); skupaj s tretjo kampato pa prostor ni imal stalnih vsebin, zato se je občasno oddajala v najem za različne prireditve (koncerti, razstave, športni in kulinarični dogodki, poroke). Lastnica objekta, Občina Piran, je želela tovrstno rabo objekta ohraniti oz. še povečati kreativno rabo kampat. Z namenom oživitve objekta, povečanja števila dogodkov ter učinkovite turistične promocije, je Občina Piran januarja 2019 s Turističnim združenjem Portorož sklenila Pogodbo o trženju dvorane št. 2 in 3 skladišča soli - Monfort. V sklopu projekta REFREsh so bile v študiji Koncepti revitalizacije za skladǐčce Monfort (GEArt 20I8) preučene možnosti programskih zasnov za tretjo kampato; analiza je bila nato razširjena na celoten objekt Monforta ter vključila tudi sosednji objekt nekdanjega skladišča Grando. Različne programske vsebine so bile analizirane v Študiji izvedljivosti vključevanja kulturnih scen $v$ razvoj industrijskih območij: primer skladišč soli Monfort in Grando v Fizinah (Plestenjak in soavtorji 20I8). $\mathrm{Na}$ osnovi teh analiz je bil podan predlog novih vsebinskih poudarkov, kot prikazuje Slika 3. Skladno z željami investitorja so bila sočasno, spomladi 2019, izpeljana gradbena dela za prenovo notranjščine tretje kampate skladišča Monfort za potrebe raznolikih prireditev.

\section{Model trženja skladišča Monfort kot centra kreativnih industrij}

V okviru projekt REFRESh smo za objekt Monfort razvili tudi strateške usmeritve trženja $s$ poudarkom na umeščanju vsebin in povezovanju kreativnih industrij s turizmom. Pri usmeritvah smo poleg že omenjenih kriterijev upoštevali tudi naslednja izhodišča:

- $\quad$ skladnost s strateškimi cilji za razvoj kreativnih industrij v državi oziroma regiji,
- skladnost s strateškimi cilji občine Piran,

- dvig kakovosti življenja lokalne skupnosti (središče dogajanja in kulture za prebivalce).

Za opredelitev smernic trženja prostora $s$ kreativnimi vsebinami predlagamo in utemeljujemo naslednje usmeritve:

a) usmeritve glede marketinških ciljev,

b) usmeritve glede vrst dejavnosti/vsebin,

c) trajnostni koncept trženja $\mathrm{z}$ vključitvijo internega trženja,

d) usmeritve glede segmentacije trga uporabnikov in tržnega pozicioniranja.

Celovito marketinško strategijo smo razvili skozi lasten model, ki nakazuje izhodišča in usmeritve ter povezave med njimi. Model je zasnovan na predpostavki o razvoju Monforta kot centra kreativnih industrij v Portorožu, ki omogoča dolgoročno korist za razvoj kreativnosti regije ter lokacije Portorož. Trženja Monforta zato ne usmerjamo le k privabljanju obiskovalcev / turistov (t.i. eksterno trženje), ampak tudi $\mathrm{k}$ povezovanju ponudnikov, ki svoje dejavnosti vključujejo v okviru Monforta, ter $\mathrm{k}$ prebivalcem območja (t.i. interno trženje). Interno trženje, ki ga splošne marketinške strategije redkeje opredeljujejo, predstavlja varovalko trajnostnega razvoja kreativne scene na turistični destinaciji, zaradi specifike kulturnih dejavnosti, ki v osnovi niso tržno naravnane. Interno trženje se na eni strani usmerja $\mathrm{k}$ raziskovanju in preverjanju potreb interne javnosti (najemnikov oziroma izvajalcev kreativnih dejavnosti na lokaciji), na drugi strani pa razvija in izvaja učinkovito komuniciranje z njimi - jih povezuje, motivira, ozavešča, izobražuje in usposablja za doseganje zastavljenih ciljev kreativnosti kraja in širše regije. Povezovanje ponudnikov oz. najemnikov Monforta se bo razvijalo skozi orodja t.i. simbioznega trženja (imenovano tudi sodelovalno ali soustvarjalno trženje).

Sestavni del marketinške strategije za Monfort je seveda tudi klasično eksterno trženje, s katerim se usmerjamo na odjemalce kreativnih dobrin oziroma obiskovalce objekta. Te bomo 


\section{IDENTITETA LOKACIJE}

\section{STRATEŠKA USMERITEV DEJAVNOSTI: CILJI, VRSTE}

\section{TRAJNOSTNO TRŽENJE}

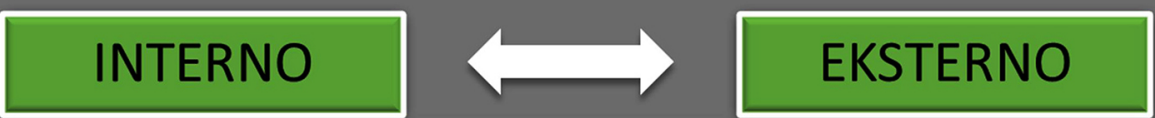

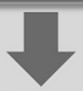

Povezovanje najemnikov

Simbiozno trženje

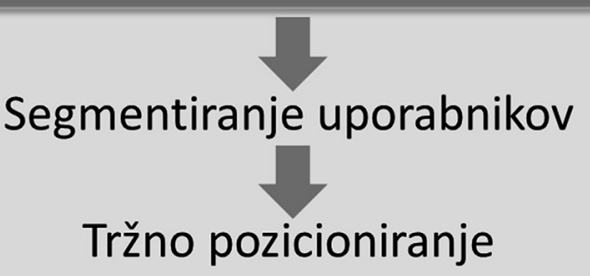

Slika 4: Pregled kreativnih funkcij prostorov v Monfortu (vir: Plestenjak in soavtorji 2018).

segmentirali v zaokrožene razlikovalne skupine s skupnimi značilnostmi. Tem skupinam se bo s skupnimi trženjskimi orodji (skupni komunikacijski kanali, cenovne politike in standardi storitev in doživetij) predstavljalo tržno pozicijo.

$\mathrm{Za}$ učinkovito trženje Monforta kot kreativne scene $\mathrm{v}$ Portorožu priporočamo novejši okvir, t.i. ${ }_{4} \mathrm{C}$ model, ki pomaga kreativcem, da $\mathrm{v}$ fazi trženja postavijo na prvo mesto vidik uporabnika kreativnih dobrin in storitev. Tradicionalni marketinški modeli (npr. ${ }_{4} \mathrm{P}$ - proizvod, cena, distribucija, promocija) se namreč že v osnovi osredotočajo na oblikovanje trgu primernega proizvoda, kar po našem mnenju ne ustreza humanistični naravi kreativnih industrij. Kreativni sektor - za razliko od gospodarstva - namreč primarno kreira dobrine iz notranjih vzgibov ustvarjalcev samih. Izravnati kreativni sektor z gospodarsko ravnjo marketinškega zadovoljevanja potreb trga, ne sme postati cilj strategije spodbujanja kreativnih scen na destinacijah.
Dejstvo pa je, da ustvarjalci lažje dosežejo uporabnike svojih dobrin, če sklopu spodbujanja kreativnosti dodamo znanja in veščine s področja trženja. Pri marketinškem pristopu ${ }_{4} \mathrm{C}$ bomo pri trženju Monforta upoštevali:

CI) kakšne so značilnosti uporabnikov določenih kreativnih dobrin (angl. customer),

C2) kakšna je najprimernejša/najprikladnejša oblika ponudbe določene kreativne dobrine (angl. convenience),

C3) kakšen je celoten strošek, ki ga je uporabnik pripravljen nameniti uporabi/nabavi kreativne dobrine (npr. ne le cena ampak tudi pot do kraja) (angl. costs),

$\left.\mathrm{C}_{4}\right)$ kakšen je učinkovit dialog z uporabniki oz. kako doseči dvosmerno komunikacijo z njimi (ne le enosmerne promocije) (angl. communication) (Londhe 2014). 
Z upoštevanjem marketinškega modela ${ }_{4} \mathrm{C}$ omogočamo kreativnim industrijam, da najprej prepoznajo in segmentirajo skupine, ki so možni odjemalci/uporabniki njihovih dobrin, nato pa pri ponudbi upoštevajo, kako te skupine iščejo informacije o kulturnih dobrinah, kako se odločajo zanje ter kje in kako jih lahko najenostavneje naročijo oz. kupijo. S pomočjo ${ }_{4} \mathrm{C}$ lahko torej ponudniki kulturnih dobrin plasirajo svojo ponudbo preko pravih kanalov tistim skupinam ljudi, ki jim kulturna dobrina predstavlja vrednost in so zanjo pripravljeni nameniti svoj prihodek, čas in energijo. Nazadnje pomaga ${ }_{4} \mathrm{C}$ tudi pri komuniciranju $\mathrm{z}$ obstoječimi in potencialnimi uporabniki, tako da jih vključi v dialog in celo $\mathrm{v}$ soustvarjanje. $S$ primernimi komunikacijami, čeprav tržnimi (npr. utrjevanje imidža, blagovne/tržne znamke, pospeševanje prodaje, oglaševanje ipd.) lahko kreativne industrije presežejo odnos ponudnik - kupec in ustvarijo odnos ustvarjalec - uporabnik in celo ustvarjalec - soustvarjalec.

\section{Strateške smernice trženja Monforta Usmeritve glede ponudbe}

Strateške usmeritve o tem, katere kreativne dejavnosti (dobrine in storitve) tržiti v obravnavanem objektu, smo valorizirali skozi tri ključna vprašanja:

I) Katere dejavnosti/proizvode labko ponudimo na obravnavani lokaciji? (npr. predlog Občine Piran glede na strategijo, interese in zmožnosti)

2) Katere dejavnosti/proizvode želimo ponuditi na obravnavani lokaciji? (predlog stroke, npr. Turističnega združenja Portorož, ki izvaja analize in strateške usmeritve)

3) Kakšni bodo (dolgoročni) učinki dejavnosti tega prostora za kraj?

Predlogi kreativnih dejavnosti, ki izhajajo iz analize stanja, analize potreb deležnikov, analize ponudnikov in analize trendov, so:

a) Primarne dejavnosti: umetnost in kultura (povezana s krajem, dediščino, lokacijo, pre- bivalci); npr. likovne in fotografske razstave, nastopi amaterskih kulturno-umetniških skupin, literarna srečanja; dejavnosti kreativnega sektorja, ki omogočajo (so)ustvarjanje skozi kreativne delavnice, co-working in druženje; npr. razvijanje AV in IKT rešitev;

b) Dopolnilne dejavnosti: kreativni dogodki, doživetja, prireditve, rekreacija; npr. plesne delavnice, joga ...

c) Neželene dejavnosti: množične zabavne prireditve (neustrezna infrastruktura in neposredna bližina bivalnega naselja); zgolj komercialno oddajanje prostora $\mathrm{v}$ najem $\mathrm{za}$ aktivnost, ki nima pozitivnega kreativnega ali promocijskega potenciala za lokalno okolje (npr. poroke ali rojstnodnevna praznovanja).

\section{Usmeritve glede trajnostnega trženja}

Da bodo marketinške aktivnosti pomagale dvigovati prepoznavnost in dolgoročni ugled lokacije, je treba v dolgoročno sodelovanje zajeti tri ključne subjekte:

- najemnike (ustvarjalce) kot interne deležnike

- obiskovalce (turiste) kot eksterne deležnike in

- partnerje (soustvarjalce).

\section{Najemniki}

Monfort kot kreativno središče združuje ponudnike kreativnih industrij $\mathrm{v}$ kraju. Kreativni ponudniki se lahko vključijo v aktivnosti Monforta na podlagi različnih potreb (npr. poceni najem prostora za svojo dejavnost, skupna uporaba osnovnih sredstev, potreba po svetovanju). $\mathrm{Za}$ dolgoročno učinkovito trženje Monforta je potrebno segment najemnikov prostora razvrstiti v segmente sedanjih in segmente potencialnih najemnikov. Za obstoječe najemnike, katerim omogočamo potrebne vire in usklajujemo pogoje ter aktivnosti skupnega trženja, pripravimo načrt internega komuniciranja. Skozi interno tržno komuniciranje utrjujemo potrebne stand- 
arde ponudbe Monforta (način in kanali prodaje, način interpretacije, organizacijska kultura), spodbujamo povezovanje in ustvarjanje nove vrednosti (novi dogodki, doživetja, ponudba, zgodbe). Za potencialne najemnike pa pripravimo načrt eksternega tržnega komuniciranja, $v$ katerem predstavimo pomen in vlogo Monforta kot kreativne scene v Portorožu ter priložnosti in koristi za najemnike (npr. zakaj najeti prav ta prostor za protokolarni dogodek, za co-working, za razstavo, koncert...).

Ključna elementa diferenciacije in konkurenčne prednosti Monforta sta arhitektura in zgodba/ dediščina, ki izhaja iz osnovne namembnosti. Usmeritve $\mathrm{v}$ zvezi s privabljanjem najemnikov (ustvarjalcev) so:

- primernost prostora za izvedbo kulturno-kreativne dejavnosti,

- visoka kulturno-kreativna in podjetniška kompetentnost najemnika,

- raznolikost kreativnih dejavnosti za potrebe doseganja sinergij interdisciplinarnosti ter $s$ tem razvoj novo kreativnosti na lokaciji.

\section{Obiskovalci}

Vrste dobrin in storitev, ki jo v Monfortu ponujajo najemniki prostora, so tiste, ki določajo vrste obiskovalcev (turistov). Ti so:

- kupci dobrin ali storitev stalnih najemnikov v Monfortu (npr. obiskovalci muzejev in galerij),

- udeleženci, ki se izobražujejo in družijo skozi aktivnosti v Monfortu (npr. obiskovalci delavnic),

- obiskovalci prireditev in dogodkov v Monfortu (glasbenih, literarnih, promocijskih),

- obiskovalci Monforta kot arhitekturne (zgodovinske, dediščinske) znamenitosti kraja.

Navedene kupce in obiskovalce ločimo glede na značilnosti Portoroža kot turistične destinacije na domačine in turiste, te pa nadalje na podsegmente, ki sledijo tržnim segmentom tu- rističnega sektorja v kraju. Po zadnjih segmentacijskih raziskavah gre za dva večja podsegmenta, in sicer za pretežno tuje turiste, nastanjene $\mathrm{v}$ portoroških hotelih, ki prihajajo z motivom uživanja v obmorskem okolju, ter za starejše pretežno slovenske $\gg$ ljubitelje narave Primorja $\ll$. Poleg omenjenih je še več manjših segmentov, kot so t. i. »iskalci kulturne avtentičnosti «, »mladi željni zabave $\ll$ in $\gg l j u b i t e l j i ~ k a m p i r a n j a \ll$ (Sedmak in Mihalič 2008).

Usmeritve v zvezi s privabljanjem obiskovalcev so:

- prepoznavnost in pozitiven kreativen imidž Monforta,

- trajnostna rast števila domačih in tujih obiskovalcev,

- medijska pokritost vsebin in aktivnosti Monforta za dvig zavedanja o pomenu kreativnega delovanja za širšo javnost/kraj/regijo.

\section{Partnerji}

Kot partnerje kreativnega središča Monfort opredeljujemo fizične in pravne osebe, s katerimi se lahko upravljavci povežejo s ciljem dolgoročnega uspešnega delovanja in trženja svojih aktivnosti. Partnerje smo opredelili glede na vrsto sektorja (kreativne industrije, gospodarstvo, izobraževanje), glede na lokacijo (turistične organizacije, tri univerze v občini) ter glede na obseg sodelovanja (npr. IKT podpora, raziskovalna dejavnost).

Usmeritve v zvezi s pritegovanjem partnerjev so:

- vzajemno koristni odnosi in razvoj kraja za bivanje in turistični obisk,

- $\quad \mathrm{v}$ javnosti priznana družbena korist delovanja tega prostora,

- prenos znanj in informacij v okolje za dvig kreativnosti in inovativnosti,

- raznolikost sektorjev, iz katerih prihajajo. 


\section{Tržna segmentacija}

Pri opredelitvi tržnih segmentov smo izhajali iz dveh ključnih vprašanj:

- Komu predstavljajo dejavnosti kreativnih industrij posebno vrednost?

- S kakšno kombinacijo kriterijev razvrstiti uporabnike $\mathrm{v}$ prepoznavne, dosegljive in merljive skupine obiskovalcev?

Za odgovore na ti dve vprašanji smo segmentirali obiskovalce/turiste glede na vrsto kreativnih industrij in glede na njihove lastnosti.

a) Glede na vrsto kreativnih industrij se osredotočimo na dve vrsti segmentov:

- uporabniki kreativnih dobrin (npr. kupci umetniških del in izdelkov umetnostne obrti, kupci oblikovalskih izdelkov, publikacij, novih medijev)

- uporabniki kreativnih storitev (npr. obiskovalci kulturnih ustanov, razstav in prireditev).

b) Glede na lastnosti uporabnikov pa se po metodologiji prepoznavanja osebnih lastnosti t.i. person (Valicon 2016) osredotočimo na naslednje tržne segmente oz. »persone«:

- t.i. raziskovalci (zanimajo jih doživetja, kultura, odločajo se na spletu...)

- t.i. urbani potrošniki (zanimajo jih muzeji, prireditve, grafiti...)

- t.i. aktivni nostalgiki (zanima jih lokalna kultura, dediščina, o ponudbi se informirajo na lokaciji...)

- t.i. lepotni navdušenci (zanima jih moda, dizajn, kulinarika, informirajo se na spletu...)

- t.i. brezskrbni mladi (zanimajo jih prireditve, koncerti, zabava, preizkušajo stereotipe...)

- t.i. večno mladi (aktivni upokojenci, zanima jih kultura, zgodovina, uporabljajo tiskane medije...)

- t.i.foodiji (zanima jih eno-gastronomija, prezentacija lokalne hrane, zgodovina...).

\section{Tržno pozicioniranje}

Monfort se mora glede na svojo identiteto pozicionirati kot arhitekturna atrakcija (v oblikovnem in dediščinskem smislu), pri čemer mora izpostaviti vrednost prostora in kreativnih vsebin. Od konkurence (npr. drugih muzejskih in galerijskih stavb, ter drugih prireditvenih prostorov $\mathrm{v}$ kraju/regiji/državi), se loči prav po svoji arhitekturno-dediščinski zapuščini ter privlačni obmorski mikrolokaciji. S tem lahko omogoča drugačno izkušnjo in dodano vrednost izvajanja in konzumiranja ponujenih kreativnih vsebin.

Glede na izsledke predhodnih analiz stanja in okolja, je marketinško podobo oziroma kreativno znamko Monforta smiselno razvijati v tri smeri:

- umetnost (likovna, glasbena, film, literatura),

- ohranjanje in interpretiranje dediščine (muzeji, razstave in dogodki, izdelki in storitve povezani z identiteto kraja/regije) ter

- festivalska dejavnost (glasba, filmi, oglaševanje, eno-gastronomija).

$S$ temi vsebinami določamo prioritete razvoja, ciljne segmente uporabnikov ter komunikacije $\mathrm{v}$ domačem in mednarodnem okolju. $\mathrm{Na}$ vse tri osrednje dejavnosti grajenja podobe kreativnega sektorja je možno in potrebno navezati tudi ostale kreativne industrije, ki bodo skozi sodobno oblikovanje in $s$ trajnostnim pristopom povezovale ustvarjalnost domačinov in doživljajsko izkušnjo obiskovalcev.

Po načelu povezovanja turizma in kreativnih industrij je turizem smiselno uporabiti kot kanal oz. "izložbeno okno" pri trženju kreativnih dobrin in storitev Monforta. Prav tako je smiselno slediti odprtosti definicije kreativnih industrij, ki dopuščajo širitev nabora klasifikacij glede na arbitrarno odločitev, kaj v nekem kraju sodi v kreativni sektor. Povezovanje kreativnih industrij in turizma je uspešneje, če kreativnost odraža avtentičnost kraja in časa, ki ju delimo s turisti. Tako nam primer Genove kaže, da je možno med kreativne industrije uvrstiti tudi sektor hrane in pijače, primeri Merana, Nice in 
Opatije pa, da je tudi sam turizem (zgodovina in dediščina turizma kraja) že postal del kreativnih industrij (npr. muzeji turizma).

\section{Simbiozno trženje kreativnih industrij in turizma}

Monfort naj v prvi vrsti povezuje ključne sektorje in kreativne subjekte za doseganje dolgotrajnih pozitivnih učinkov kreativnih industrij za lokacijo. Simbiozno, imenovano tudi sodelovalno ali soustvarjalno trženje, lahko pomembno prispeva $\mathrm{k}$ trajnostnemu razvoju združenih ponudnikov in lokacije. Za razliko od tradicionalnega trženja, $\mathrm{v}$ okviru katerega (turistični) ponudniki skrbijo le za razvoj proizvodov, cen, distribucijskih kanalov in promocije, se s simbioznim trženjem kreativnih industrij zasledujejo:

- $\quad$ širše koristi kreativne scene za kraj / regijo,

- celovita vrednost uporabe Monforta za ponudnike, uporabnike in partnerje,

- prilagajanje okoliščinam, ki vplivajo na dejavnosti in uporabo/obisk Monforta (npr. trendi, vreme, politika),

- cilji prepoznavnosti in komuniciranja $\mathrm{z}$ različnimi javnostmi.

Analiza stanja in potreb po kreativni sceni $\mathrm{v}$ Portorožu kaže na potrebo po vertikalnih in horizontalnih povezovanjih ponudbe in promocije. Za trajnostni razvoj kreativnih industrij v Monfortu se morajo zato združiti resursi, procesi in programi trženja med istovrstnimi ponudniki (npr. muzeji, umetniki, oglaševalci) ter med vertikalno komplementarnimi ponudniki (npr. ponudniki turističnih storitev, raziskovalci, kreativni izvajalci). Vrste možnih oblik sodelovanja med internimi deležniki so so-uporaba in razvoj komunikacijskih in prodajnih kanalov (interaktivne spletne strani in e-trgovina, blogi itd.), skupno oz. koordinirano iskanje možnosti za učinkovito valorizacijo učinkov kreativnih industrij, povezovanje z zasebnim sektorjem na področju kreativnih marketinških storitev, s sekcijami gospodarske zbornice in tudi z javnim sektorjem. Nenazadnje je, kot že omenjeno, v Piranski občini tudi veliko odprtih možnosti za sodelovanje z raziskovalno-izobraževalnim institucijami pri spodbujanju povezav med kreativnimi industrijami in turizmom. Glede na težo, ki jo ima v tem okolju, izpostavljamo zlasti možnosti sodelovanja z Univerzo na Primorskem, katere pridružena članica je tudi Fakulteta za dizajn, neposredno vpeta v razvoj kadrov kreativnih industrij. $\mathrm{Ob}$ njej so kreativne vsebine posredno ali neposredno prisotne tudi na drugih fakultetah, npr. portoroška Fakulteta za turistične študije - Turistica, kjer izobražujejo in raziskujejo kulturni, dediščinski in inovativni turizem, koprska Pedagoška fakulteta in Fakulteta za humanistične študije, ki pokrivata področje umetniške dejavnosti in medijev, Fakulteta za management, kjer razvijajo design management in podjetniške kompetence, ki so potrebne za učinkovito in uspešno valorizacijo učinkov kreativnih industrij. V povezavi z univerzo je treba omeniti tudi Center odličnosti InnoRenew CoE - neodvisni raziskovalni inštitut, ki spodbuja kulturo odprtih inovacij s poudarkom na interdisciplinarnemu proučevanju lesa in njegove uporabe $s$ ciljem razvijati konkurenčno prednost regije in države.

Ključna gospodarska dejavnost, s katero se mora razvijati simbiozno trženje kreativnih industrij v Monfortu, je turistično gospodarstvo. Turistični ponudniki lahko oblikujejo s kreativnimi industrijami sinergije na področju vključevanja kreativnih industrij v turistično ponudbo in na področju inovativnega tržnega komuniciranja turistične destinacije. V sklopu različnih že izpeljanih projektov povezovanja turizma in kreativnih industrij v občini so: Kreativne ideje za podjetniško soustvarjanje novih turističnih proizvodov (KIPSNTP), Wellness Istra, TURIZEM 4.0 - obogatene turistične izkušnje, Izkusimo istrsko podeželje: novi (tematski) turistični produkti in njihova promocija (TURIZMO IŠTRIANO), Skupna dediščina za skupno mednarodno promocijo 365 dni zelenega turizma na Opatijski in Portoroški rivieri (Riviera4Seasons2), Quality Network on Sustainable Tourism (QNeST), 
Komunizem in turizem: sodobne prezentacije in interpretacije s pomočjo informacijske tehnologije (TITOUR).

\section{Zaključek}

$\mathrm{V}$ članku smo prikazali pomen, priložnosti in metodologijo povezovanja turizma, dediščine in kreativnih industrij na primeru Monforta v Portorožu. Gre, kot kažejo nekateri primeri iz tujine, za izredno kompleksno, hkrati pa potencialno zelo perspektivno kombinacijo dejavnosti oz. področij, kjer se pojavlja vrsta možnih sinergij. Medtem ko sta turistični in dediščinski vidik skladišč soli bila $\mathrm{v}$ preteklosti že deležna več resnih obravnav, so kreativne industrije še dokaj neraziskano in slabo razumljeno področje, kar bo pri implementaciji predlaganih rešitev gotovo predstavljalo velik izziv. Poleg šibke raziskanosti so kreativne industrije specifične tudi zaradi notranje heterogenosti - tako vsebinske in organizacijske kot konceptualne, kar zahteva fleksibilnost pristopov in obravnav tega segmenta $\gg$ trojčka $\ll$.

$S$ pomočjo analize strateških dokumentov, pregleda teoretičnih podlag in primerov dobrih praks ter terenskega dela in sestankov z različnimi deležniki smo prišli do nabora priporočljivih vsebin skladišča in oblikovali teoretični okvir simbioznega trženja Monforta. Ta upošteva tako strateške smernice piranske občine, načela varovanja dediščine in trajnostnega delovanja, predstavlja pa lahko tudi primerno osnovo za sorodne primere povezovanja obravnavanih dejavnosti.

$\mathrm{V}$ nadaljevanju bo potrebne veliko kontinuirane multilateralne komunikacije med vsemi identificiranimi deležniki, da se bo predlagani okvir smiselno napolnil s konkretnimi vsebinami. Ključni organizacijski akter bi morala pri tem biti občinska uprava, upoštevajoč, da pri tej vlogi ne gre le za en projekt, ampak je spodbujanje in podpora aktivnemu usklajevanju in povezovanju vseh deležnikov strateškega pomena za uspešen razvoj občine.

\section{Povzetek}

Skladišča soli Monfort in Grando v Portorožu sta industrijska dediščina zaščitena kot spomenika lokalnega pomena. Skladišče Monfort je bilo predmet analize in prenove v okviru Interreg projekta REFREsh (pod okriljem Zavoda za varstvo kulturne dediščine Slovenije), s ciljem da se določi nova namembnost, ki bi temeljila na kreativnih industrijah. V ta namen je bila narejena interdisciplinarna študija, $s$ katero so bili oblikovani predlogi za nove rabe ter modeli trženja teh rab. Model trženja skladišča Monfort kot centra kreativnih industrij, ki vključuje tudi povezovanje s turizmom, predvideva aktivnosti eksternega in internega trženja. Prvo bo usmerjeno $\mathrm{k}$ prepoznavanju potreb in privabljanju obiskovalcev/kupcev/turistov (to so npr. obiskovalci muzejev, delavnic, prireditev ...), drugo pa k ponudnikom oz. najemnikom prostorov in prebivalcem območja. Pri eksternem trženju je ključna segmentacija in prilagoditev ponudbe in trženjskega spleta posameznim segmentom (domačim oz. tujim turistom, različnim psihografskim segmentom, kot so iskalci avtentičnosti, mladi željni zabave itd.). Namen tega dela trženja je zadovoljevanje potreb obiskovalcev in zagotavljanje finančne uspešnosti delovanja najemnikov/ponudnikov. Pri internem trženju pa je ključno razumevanje potreb internih javnosti (najemnikov oziroma izvajalcev kreativnih dejavnosti na lokaciji in lokalne skupnosti), z namenom učinkovitega komuniciranja z njimi - s ciljem ozaveščanja, povezovanja, motiviranja, izobraževanja in usposabljanja za doseganje zastavljenih ciljev kreativnosti kraja in širše regije. Skozi interno tržno komuniciranje se oblikujejo in utrjujejo standardi ponudbe Monforta (način in kanali prodaje, način interpretacije, organizacijska kultura) ter spodbuja povezovanje in ustvarjanje nove vrednosti (novi dogodki, doživetja, ponudba, zgodbe). Monfort se mora glede na svojo identiteto pozicionirati kot arhitekturna-dediščinska atrakcija na privlačni obmorski mikrolokaciji, pri čemer mora izpostaviti vrednost prostora in kreativnih vsebin. Za doseganje dolgotrajnih pozitivnih učinkov kreativnih industrij za kraj predlagamo simbiozno ali soustvarjalno trženje, ki predvideva povezovanje ponudbe in promocije tako na horizontalni (med istovrstnimi ponudniki - npr. muzeji, umetniki, oglaševalci) kot vertikalni (npr.s ponudniki turističnih storitev, raziskovalnimi inštitucijami ...) ravni. 


\section{Summary}

The warehouses of Monfort and Grando in Portorož are protected as cultural heritage and listed as monuments of local importance. Monfort warehouse has been subject to analysis and renovation within the REFREsh Interreg project (under the aegis of the Institute for the protection of cultural heritage of Slovenia), with the aim to identify a re-use linked to creative industries. For this purpose, an interdisciplinary research was carried out which formulated proposals for new uses and the related marketing model. The marketing model for Monfort warehouse as a centre for creative industries, which integrates also links with tourism, envisages external and internal marketing activities. The former aims at identifying needs and attracting visitors/buyers/ tourists (i.e. Visitors to museums, workshops, events etc.), and the latter to providers or tenants and residents of the area. In the external marketing, segmentation and adaptation to the offer and marketing mix to individual segments (domestic or foreign tourists, different psychographic segments, such as authenticity seekers, young people seeking entertainment etc.) is crucial. This section of marketing aims at meeting the needs of the visitors and ensuring the financial performance of tenants/providers. In the case of internal marketing, understanding the needs of internal publics (tenants or creative industry providers at the site and local community) is crucial in order to communicate effectively with them - with the aim of raising awareness, connecting, motivating, educating and training for achieving the set goals to develop creativity of the place and the wider region. Through internal market communication, Monfort's offering standards (manner and channels of sale, method of interpretation, organisational culture) are formed and consolidated, while promoting connection and creation of new values (new events, experiences, offer, stories). Monfort has to position itself as an architectural and heritage attraction on its attractive seaside micro-location, highlighting the value of space and creative content. To achieve long-lasting positive effects of creative industries for the area, we suggest a symbiotic or co-creative marketing, which involves linking supply and promotion to both horizontal (between similar providers - e.g. museums, artists, advertisers) and vertical (ed with tourist service providers, research institutions ...) level.

\section{Literatura in viri}

Breznik Močnik, M., Lipovšek, B., Pivec, H., Stepančič, L., Širca, M. in Tivadar, B. 20II. Kulturne in kreativne industrije po slovensko, Ministrstvo Republike Slovenije za kulturo. https://tovarna.org/fileso/ active/3/brosura-web-si.pdf

Center za kreativnost. 2019. "O nas". https:// www.czk.si/O_nas.

CISAC. 2015. "Cultural times, The first global map of cultural and creative industries." https://en.unesco.org/creativity/sites/ creativity/files/cultural_times._the_first global_map_of_cultural_and_creative_ industries.pdf

Direktorat za kulturno dediščino, Ministrstvo za kulturo RS Slovenija. 20r8. "Strategija kulturne dediščine za obdobje 20ı82026; Osnutek (12.2.2018)”. Ljubljana: Ministrstvo za kulturo. http://www. mk.gov.si/fileadmin/mk.gov.si/ pageuploads/Ministrstvo/Zakonodaja/ Predpisi_v_pripravi/2018/Strategija_ KD_2018-02-19.pdf.

EU Commission. 2010. "Greenpaper. Unlocking the potential of cultural and creative industries". https:// op.europa.eu/en/publication-detail/-/ publication/Icb6f 484-074b-4913-87b3344 ccforoeef/language-en

Florida, R. 2002. The Rise of the Creative Class: And How It's Transforming Work, Leisure, Community and Everyday Life. New York: Basic Books.

FORA. 20ro. "New Cluster Concepts Activities in Creative industries". Copenhagen: FORA, Danish Enterprise and Construction Authority's Division for Research and Analysis - http://www. rosted.nu/attachments/File/2010/creative_ industries.pdf

GEArt. 20I8. Študija izvedljivosti koncepta revitalizacije v objektu Monfort. Nazarje: GEArt, Vizualne komunikacije d.o.o. 
Gombač, S. in Brezovec T. 2007. Letalas sidrom. Hidroavioni v Portorožu in okolici. Ljubljana: Tehniška založba Slovenije.

Lesjak, M., Brezovec, T. in Fabjan, D. 2018. "Strategija razvoja turizma v občini Piran". Univerza na Primorskem, Fakulteta za turistične študije - Turistica, Portorož. Dostopna na https://www.portoroz.si/si/ files/default/PDF/Partnerji/Strategija\%2O rzavoja\%2oturizma\%2oob\%c4\%8dine $\% 20$ Piran\%2odo\%2oleta\%202025.pdf

Londhe, B. R. 2014. "Marketing Mix for Next Generation Marketing”. Procedia Economics and Finance. Dostopno na www.sciencedirect.com 2212-567I (C) 2014 Elsevier B.V. http://creativecommons.org/ licenses/by-nc-nd/3.0/

Plestenjak, A., Vesenjak, A. in Čebron Lipovec N. 2018. "Študija izvedljivosti vključevanja kulturnih scen v razvoj industrijskih območij: primer skladišč soli Monfort in Grando v Fizinah.” Interna študija projekt REFRSh. Ljubljana, Zavod za varstvo kulturne dediščine Slovenija.

Sedmak, G., Mihalič, T. 2008. "Authenticity in mature seaside resorts." Annals of Tourism Research, 35 (5), 1007-1031.

UNCTAD. 2010. "Creative economy report 20Iо”. https://unctad.org/en/Docs/ ditctab20103_en.pdf

Valicon. 2016. "Persone ciljnih skupin slovenskega turizma." Poročilo projekta. Dostopno 30.10.2019 na: https://www. slovenia.info/uploads/dokumenti/ raziskave/stors7_persone_ciljnih_skupin_ slo_turizma.pdf 
Studia universitatis hereditati je humanistična znanstvena revija za raziskave in teorijo kulturne dediščine z mednarodnim uredniškim odborom. Objavlja znanstvene in strokovne članke s širšega področja kulturne dediščine (arheologija, arhitektura, etnologija, jezikoslovje, literarna, kulturna, glasbena, intelektualna, religijska, vojaška zgodovina, zgodovina idej itn.) in pregledne članke ter recenzije tako domačih kot tujih monografij z omenjenih področij. Revija izhaja dvakrat letno. Izdajata jo Fakulteta za bumanistične studije (Oddelek za arbeologijo in dediscino) in Založba Univerze na Primorskem.

Poglavitni namen revije je prispevati k razvoju raziskav kulturne dediščine v najširšem in k topoglednemu interdisciplinarnemu pristopu $k$ teoretičnim in praktičnim raziskovalnim vprašanjem. Tako revija posebno pozornost namenja razvoju slovenske znanstvene in strokovne terminologije, konceptov in paradigem na področju raziskovanja kulturne dediščine v okviru humanističnih ved.

Naslov uredništva

Studia universitatis hereditati, uredniški odbor / editorial board

Fakulteta za humanistične študije Univerze na Primorskem, Titov trg 5 ,

SI-600o Koper

suh.editorial@fhs.upr.si

\section{Navodila za avtorje}

\section{Guidelines for authors}

Norme redazionali 


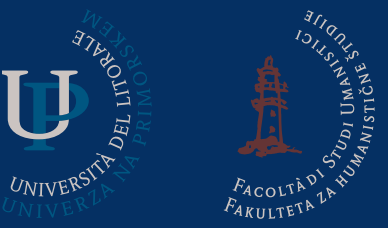

Založba Univerze na Primorskem www.hippocampus.si ISSN 2350-5443

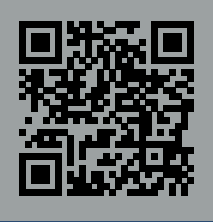

